Fall 1950

\title{
1950 Cedrus Yearbook
}

\section{Cedarville College}

Follow this and additional works at: https://digitalcommons.cedarville.edu/yearbooks

Part of the Higher Education Commons, Organizational Communication Commons, and the Public Relations and Advertising Commons

\section{Recommended Citation}

Cedarville College, "1950 Cedrus Yearbook" (1950). Yearbooks. 64.

https://digitalcommons.cedarville.edu/yearbooks/64

This Book is brought to you for free and open access by DigitalCommons@Cedarville, a service of the Centennial Library. It has been accepted for inclusion in Yearbooks by an authorized administrator of DigitalCommons@Cedarville. For more information, please contact digitalcommons@cedarville.edu. 


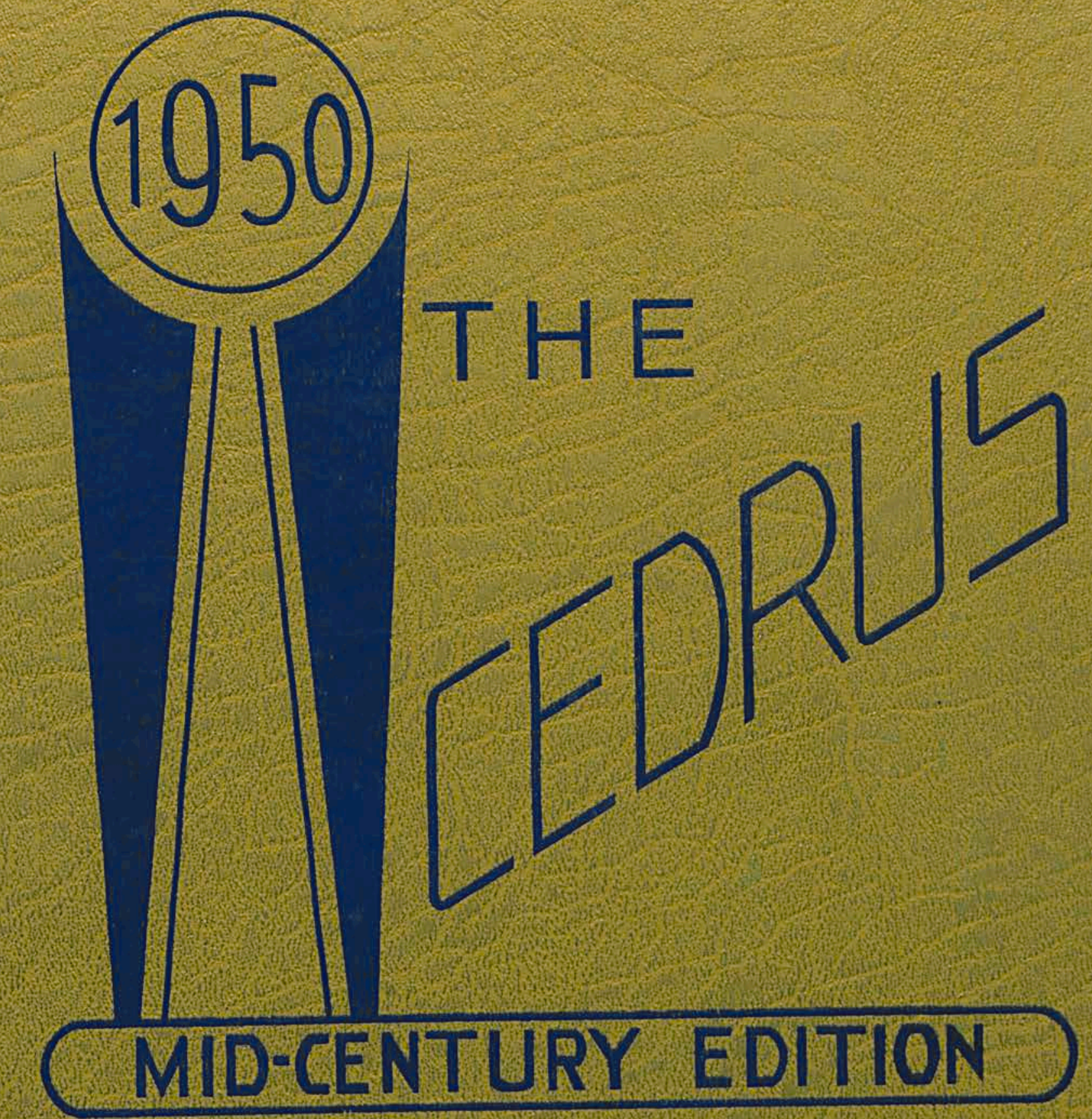


Original property of Eugene tanks Sallie

$$
1927-1979
$$

Cedarvill College class of 1950 



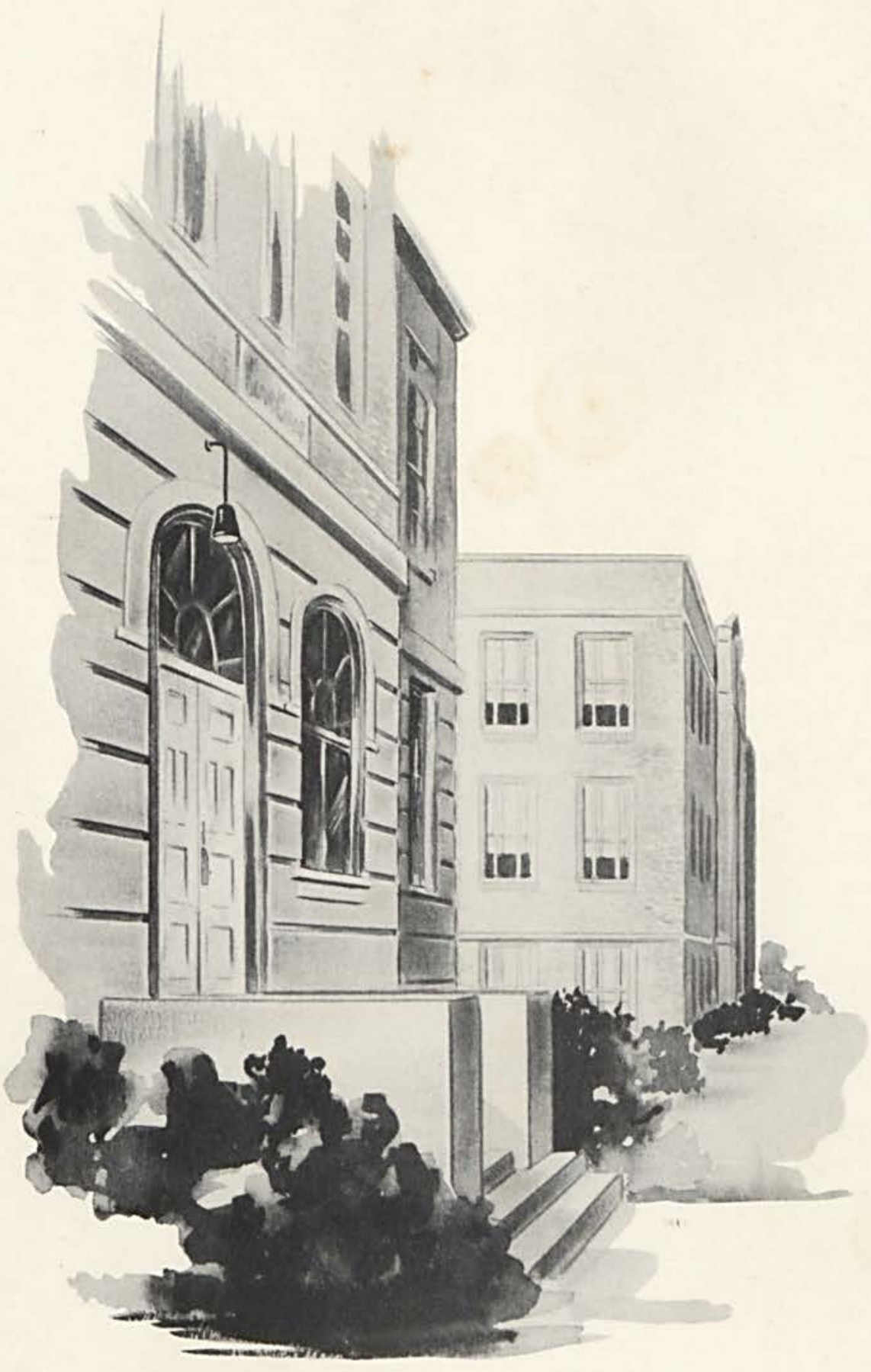




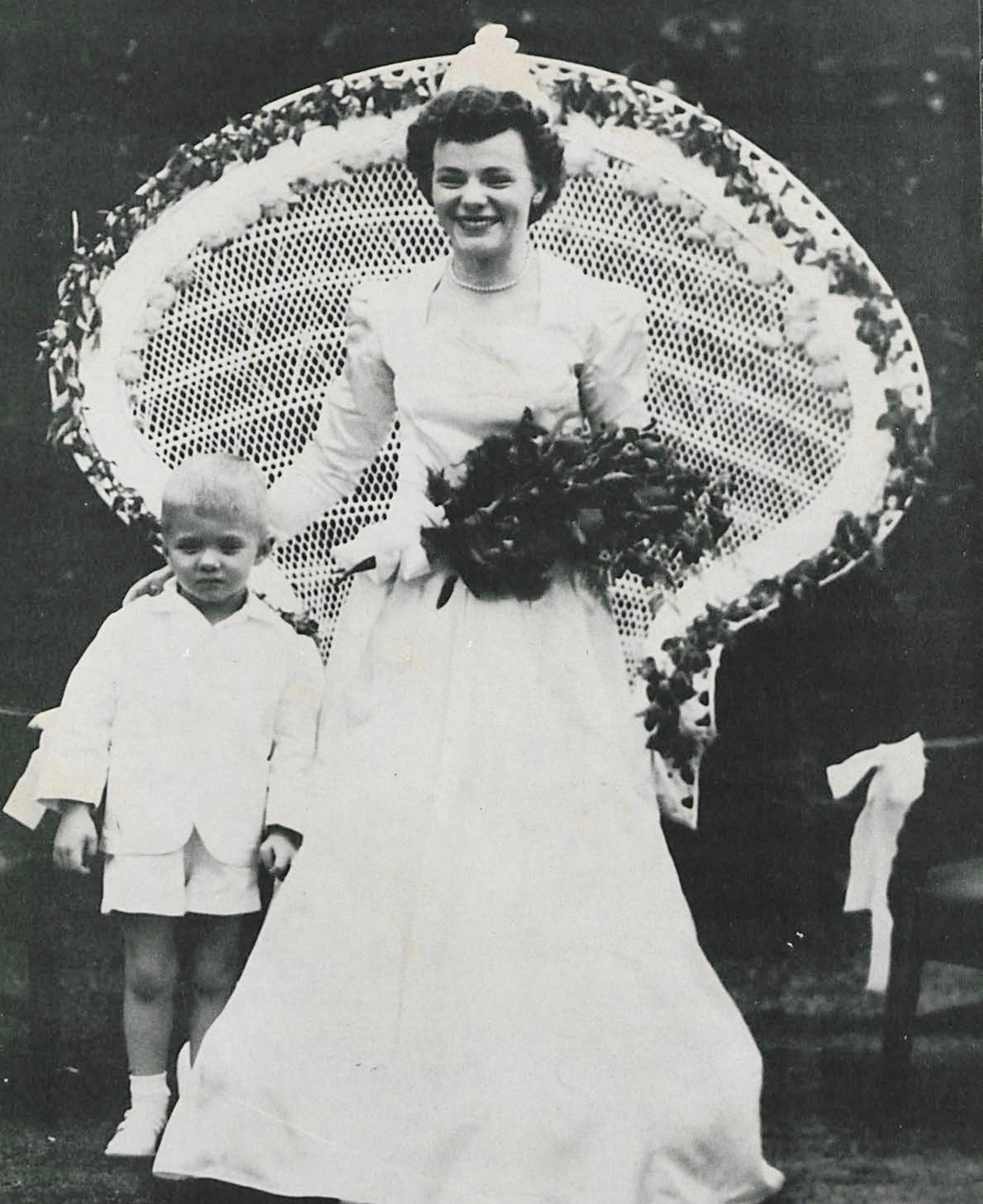




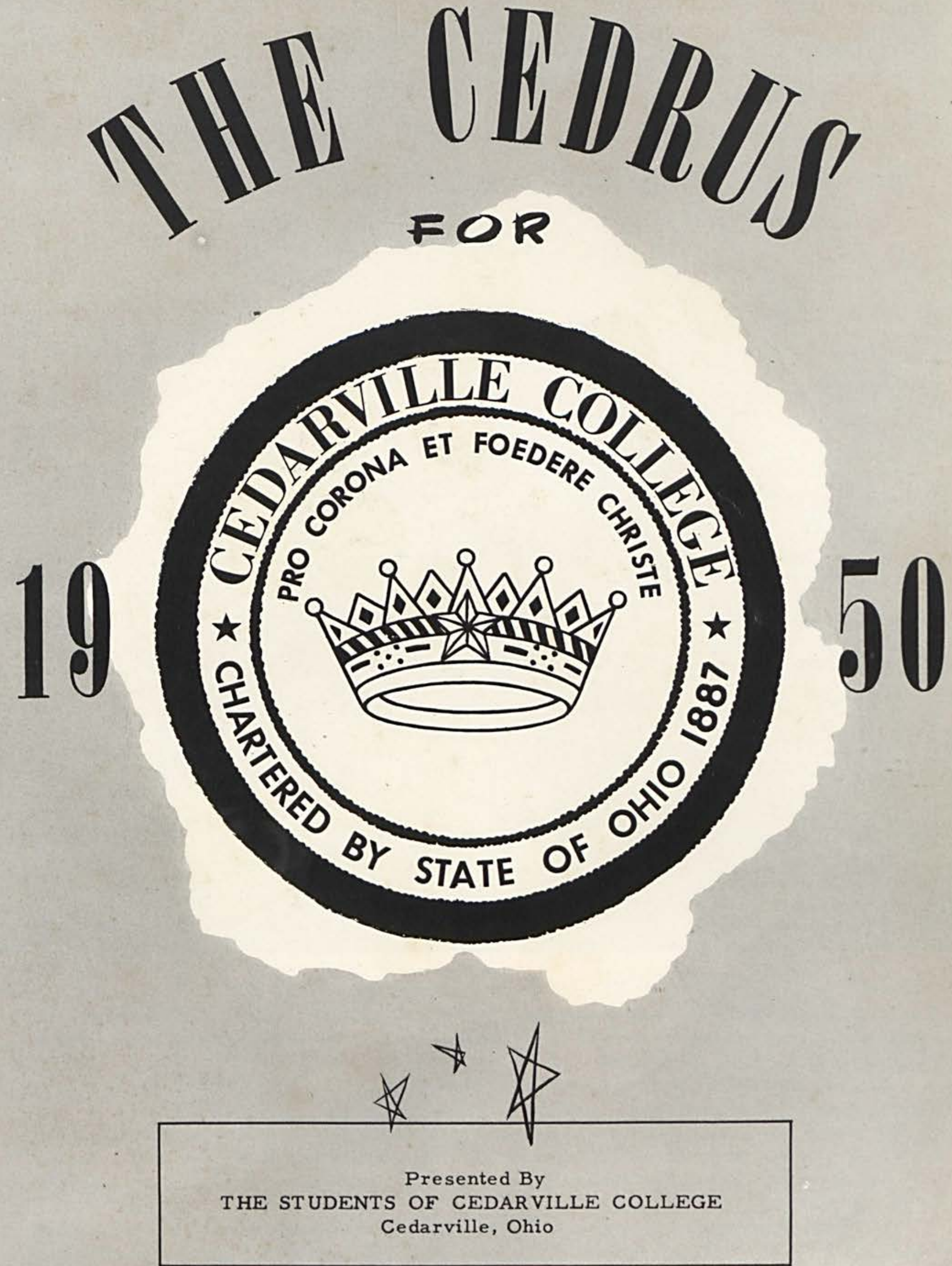




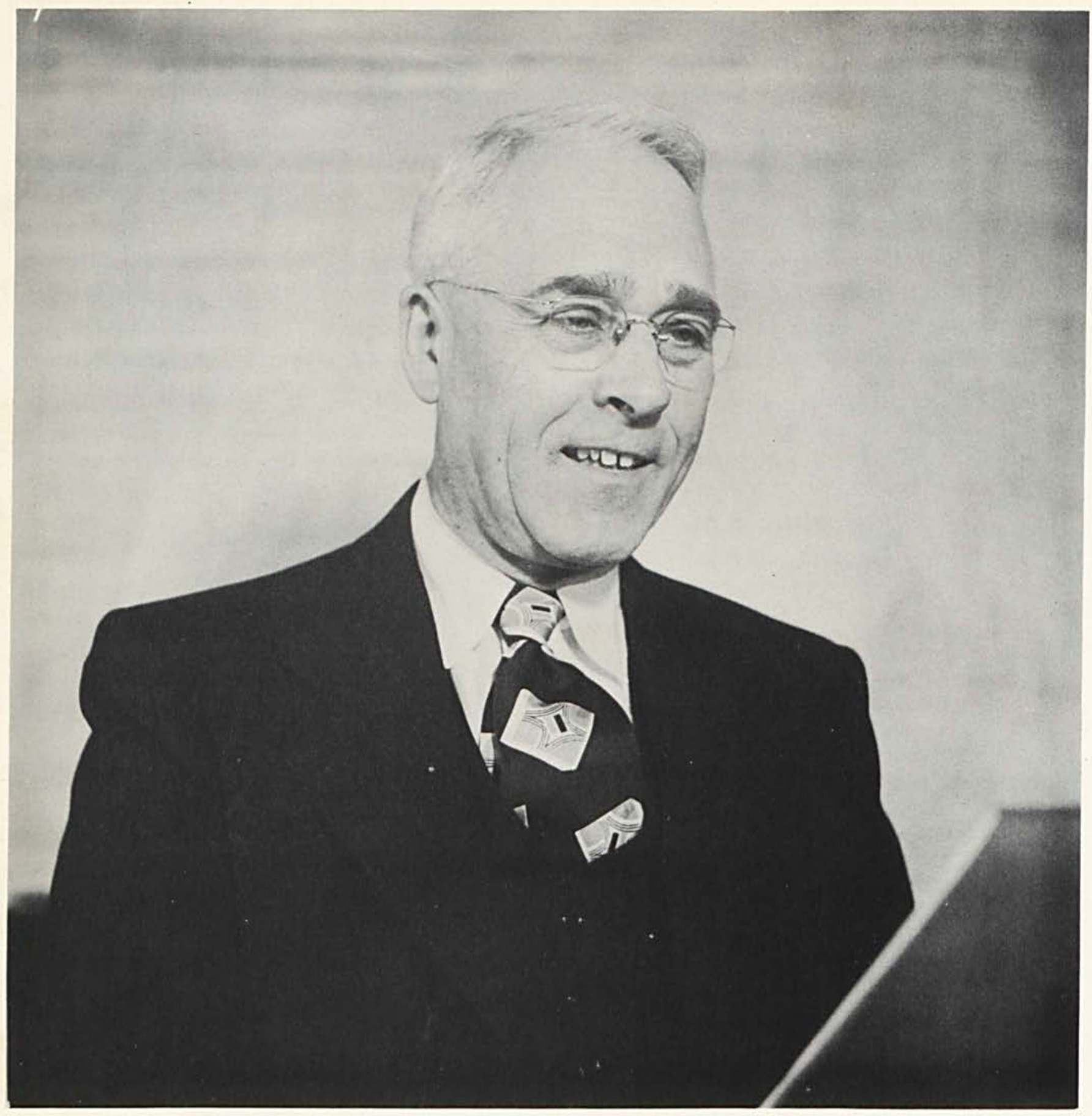

PRESIDENT Ira D. Vayhinger B.A., D.D.

"To train students to think clearly and express themselves with Christianconviction about the present day problems" is the slogan of Cedarville College directed by Ira D. Vayhinger, B.A., D.D., president.

"Can the Small School progress" is the question that is being answered in the affirmative at Cedarville College.

By prayer, by hard work, by broadthinking on the part of the entire personnel, under the supervision of President Vayhinger, Cedarville College has attained a high standing with our State Department of Education, and also has a good reputation in all the surrounding areas.

President Vayhinger is tireless in his efforts to make Cedarville grow far beyond the dreams of the past. He is anxious to make it a place of thorough preparation for life and the building of high ideals for future generations. 


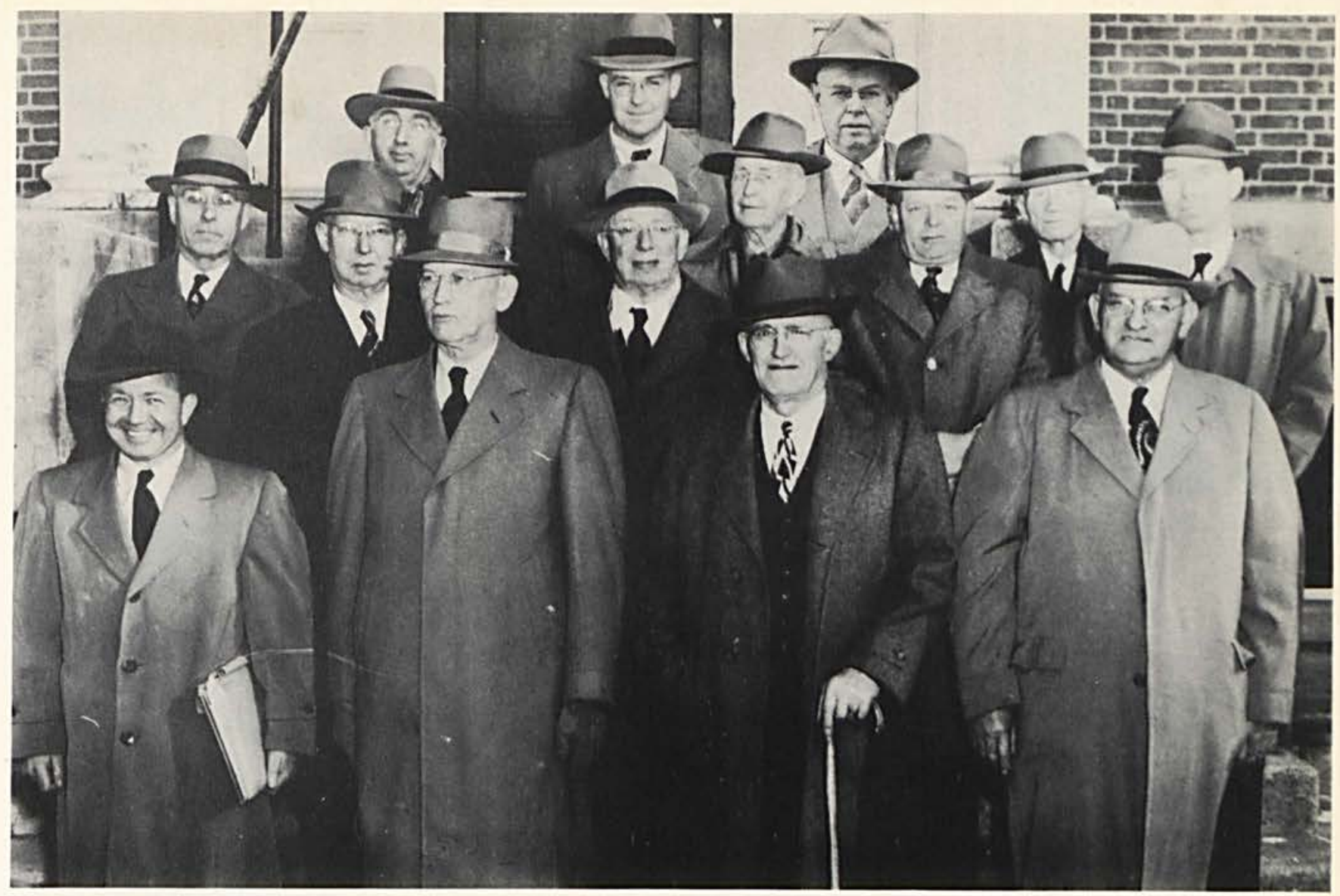

FIRST ROW: HARVEY AULD, JOSEPH A. FINNEY, GEORgE H. HARTMAN, DR. LEO ANDERSON. SECOND ROW: IRA D. VAYHINGER, JOHN W. BICKETT, JOHN L. DORST, KARLH BULL, RALPH RIFE, WALTER C. ILIFF, DR. DONALD F. KYLE. THIRD ROW: R. W. USTICK, RANKIN MCMILLAN, DAVID BRADFUTE.

\section{Trustees}

TERMS EXPIRE 1950

GeORge H. HARTMAN, MERchant . . . . . . . . . . . . . . CedarVille LESLIE S. DEAN, M.D., I2I, PHYSICIAN. . . . . . . . ROCKY RIVER JOHN L. DORST, RETIRED. . . . . . . . . . . . . . . . . SPRINGFIELd

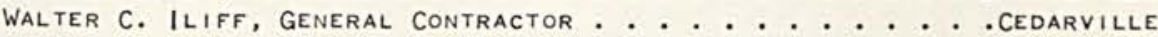
TERMS EXPIRE 1951

LEO ANDERSON, D.V.M., Veterinarian. . . . . . . . . . CedarVille JOHN W. BICKETT, D.D., 197, MINISTER. . . . . . . . . . . CLIFTON HARVEY C. Auld, 129, BANKER ........... SPRINGGield

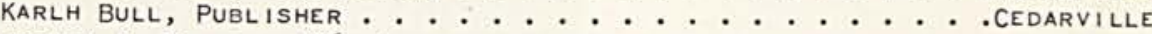
JOSEPH A. FINNEY, 106, ATtORNEY-AT-LAW. . . ....... XENIA RALPH RIFE, 122, FARMER . . . . . . . . . . . . . Cedarville R. W. USTICK, D.D., III, MINISTER.......... . SPRINGFIELD TERMS EXPIRE 1952

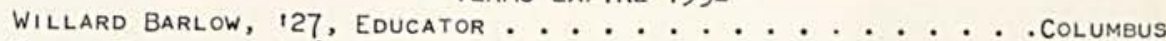
David Bradfute, $1 / 6$, Postmaster .............. Xenia Donald KYle, M.D., PHYSICIAN. . . . . . . . . . . . . CEdarVILlle

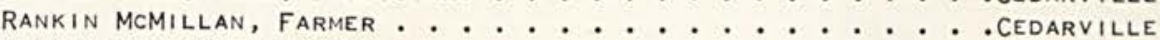

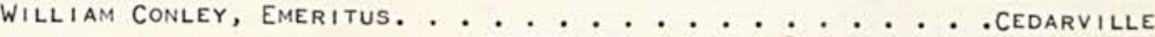
OFFICERS

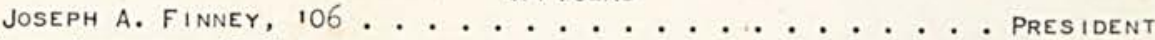
LEO ANDERSON, D.V.M.................... . . . . . . . . . . . . . . PRES.

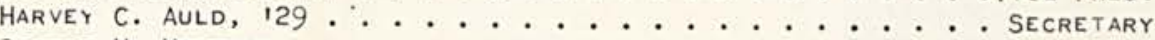

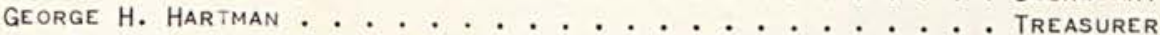
IRA D. VayHinger, D.D., PResident of College. . . . . . . .eX officio 


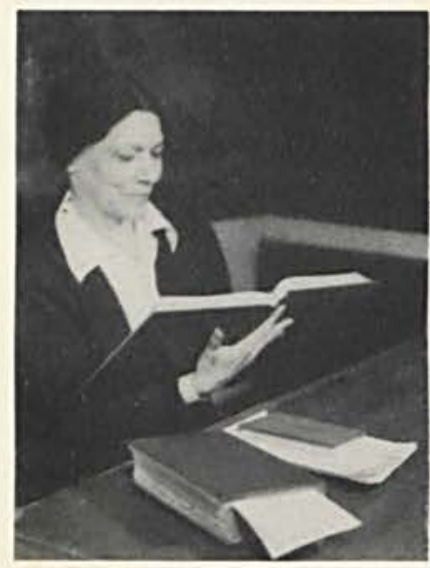

HELEN SANTMEYER DEAN OF WOMEN LATIN \& ENGLISH

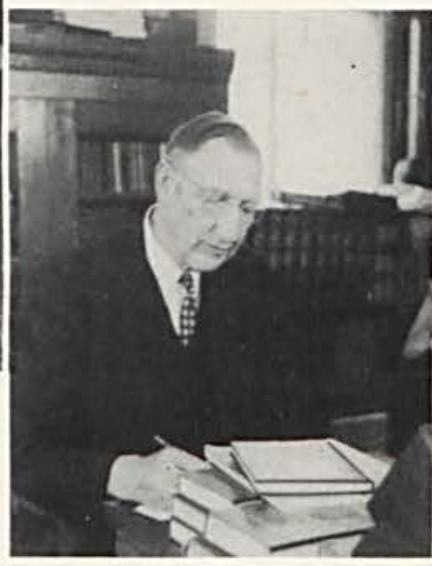

DR. F. A. JURKAT HEAD OF THE SEMINARY PROF. OF LANGUAGES

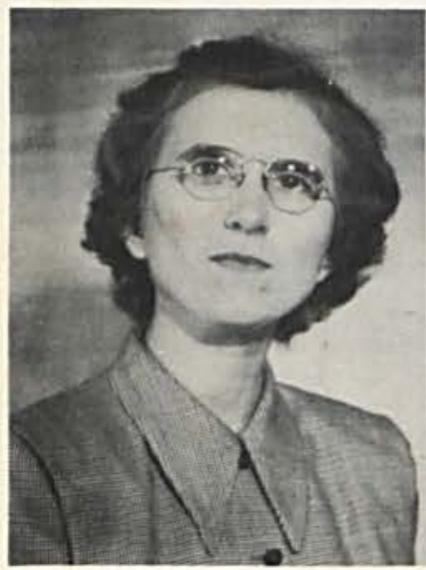

EUNICE SNYDER ENGL ISH

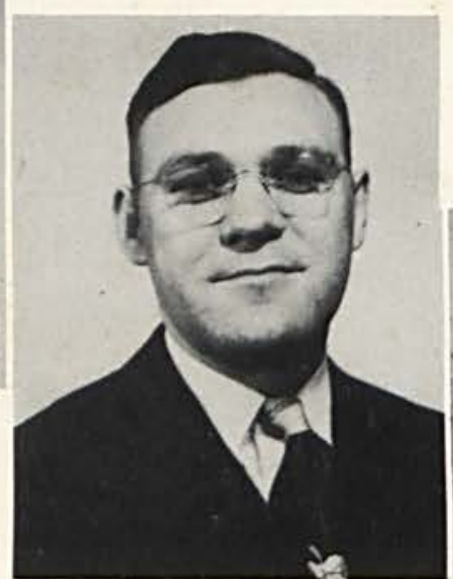

FREDERICK M. CARLSEN BIBLE \& SEMINARY

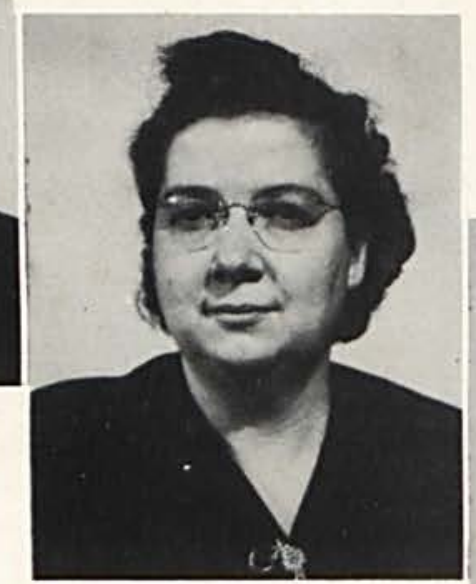

OLIVE BRILL CARLSEN

ENGLISH \& LITERATURE

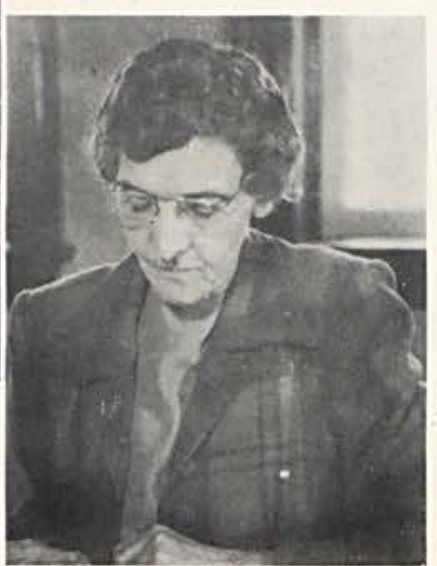

CARRIE M. RIFE

DIRECTOR OF TEACHER EDUCATION SPEECH \& LATIN

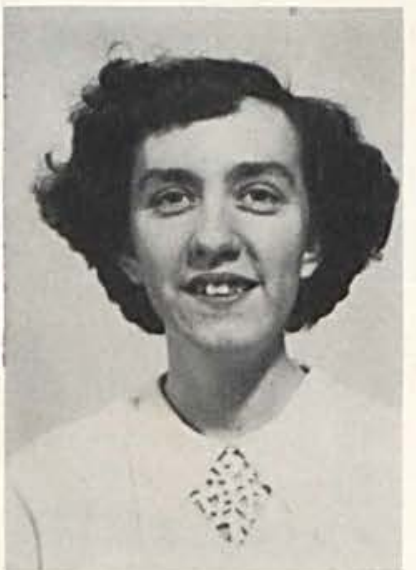

NANCY BOST

Music

JAMES RAMSEY

BIOLOGICAL SCIENCES 

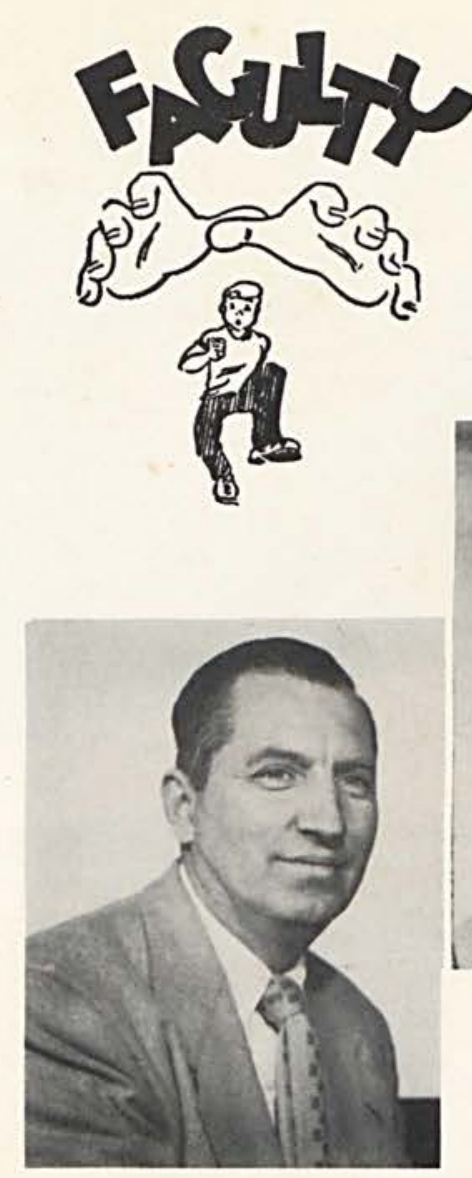

MENDELL E. BEATTIE DEAN OF MEN

PHYSICAL EDUCATION
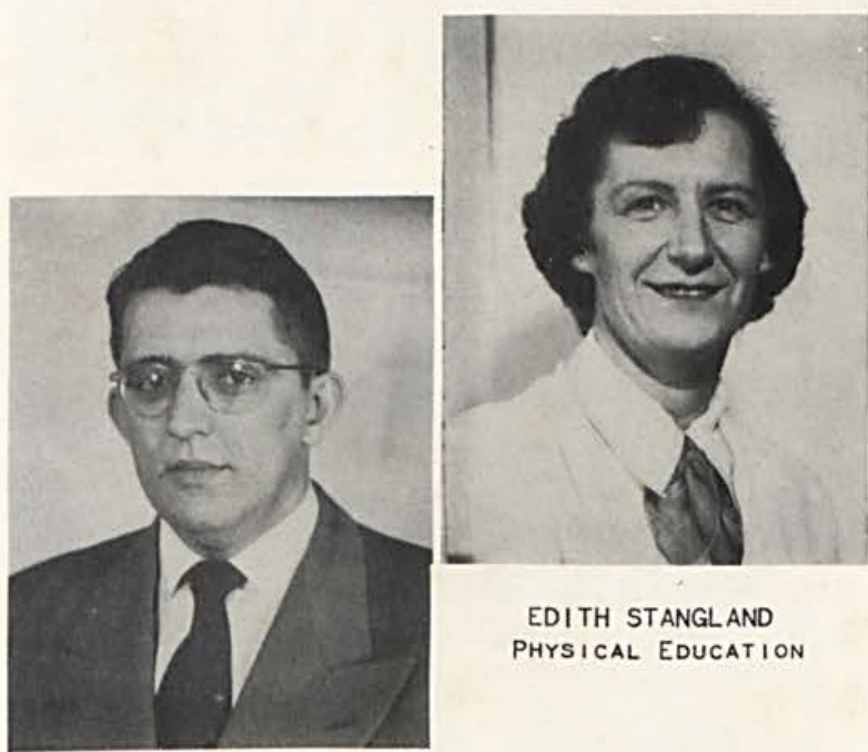

EDITH STANGLAND PHYSICAL EDUCATION

\section{GILBERT DODD \\ ACADEMIC DEAN \\ GEOGRAPHY}
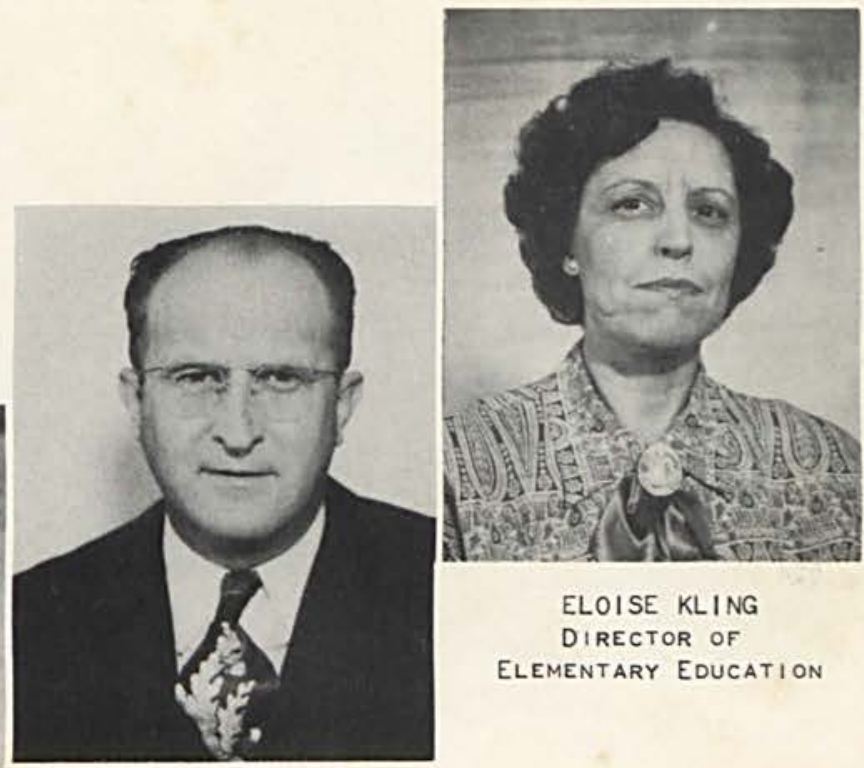

ELOISE KLING

DIRECTOR OF

ELEMENTARY EDUCATION

JAMES J. HALL

REGISTRAR

EDUCATION \& SOCIAL SCIENCES

DON GAST

HISTORY
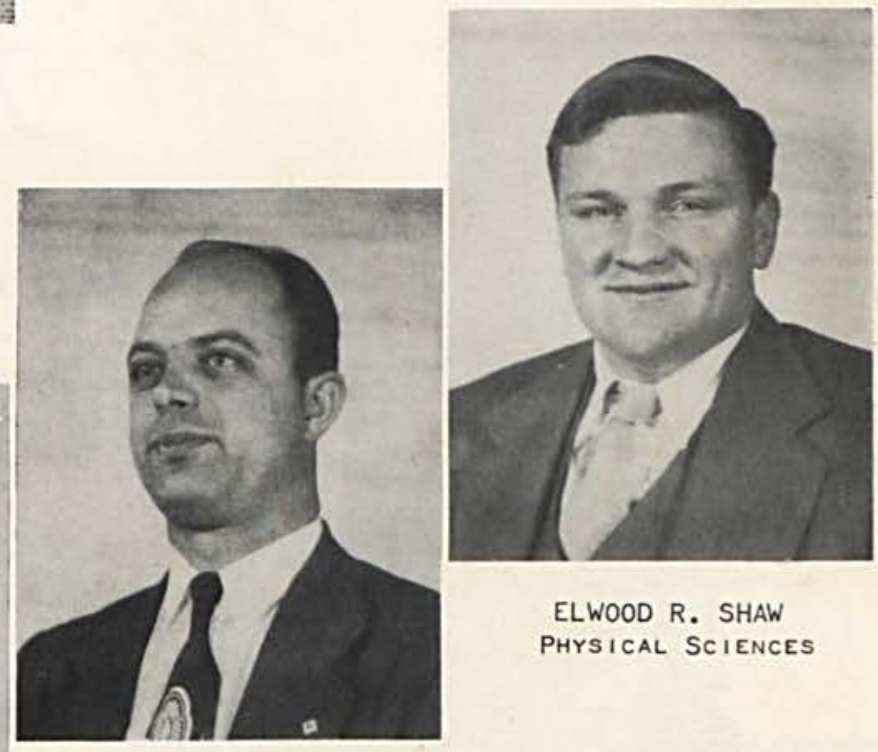

ELWOOD R. SHAW

PHYSICAL SCIENCES

\section{HOWARD WISE}

MATHEMATICS

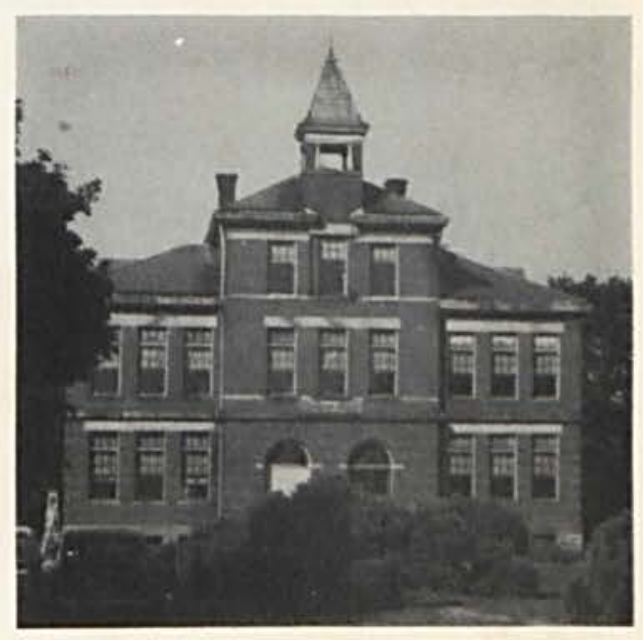



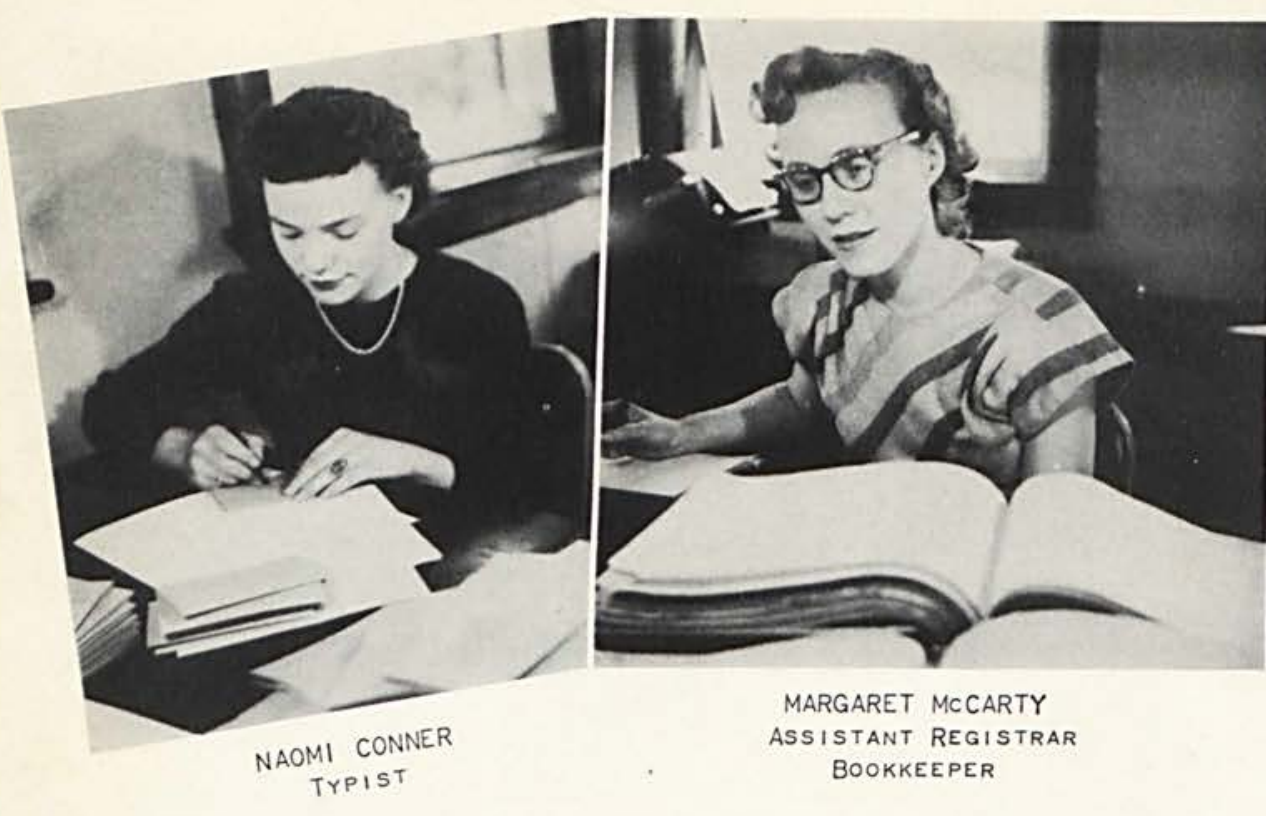

ASSISTANT REGISTRAR

BOOKKEEPER

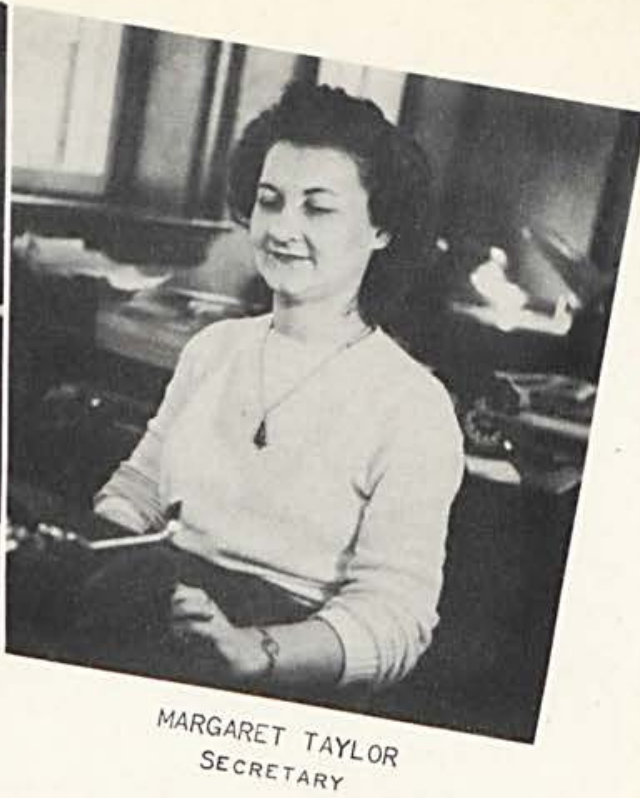

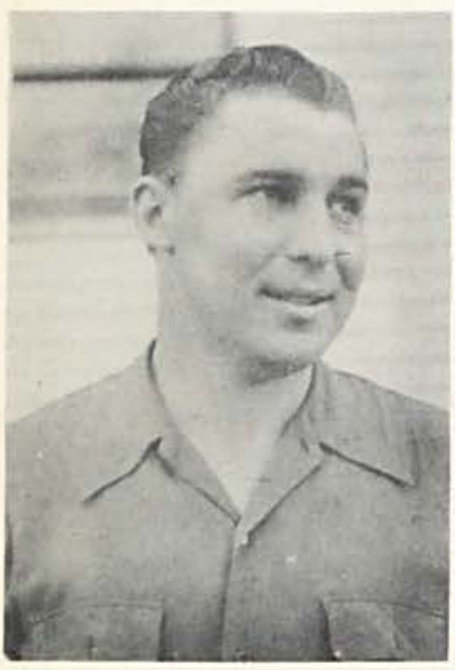

JOHN BLAZER

SUPERINTENDENT OF

BUILDINGS \& GROUNDS

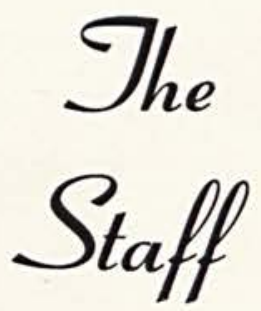

MARY WILLI AMSON

LIBRARIAN

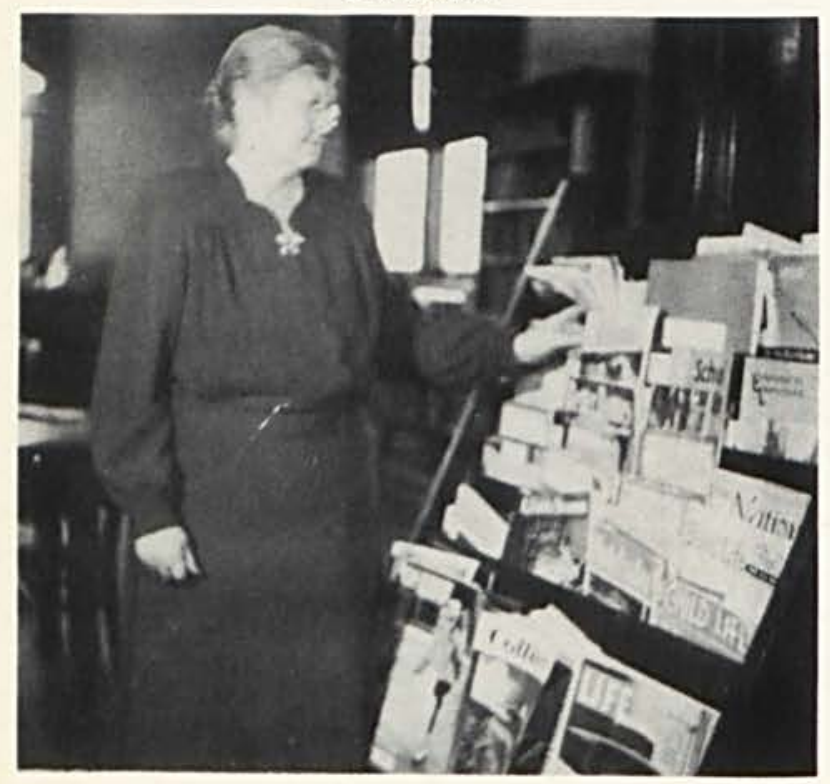

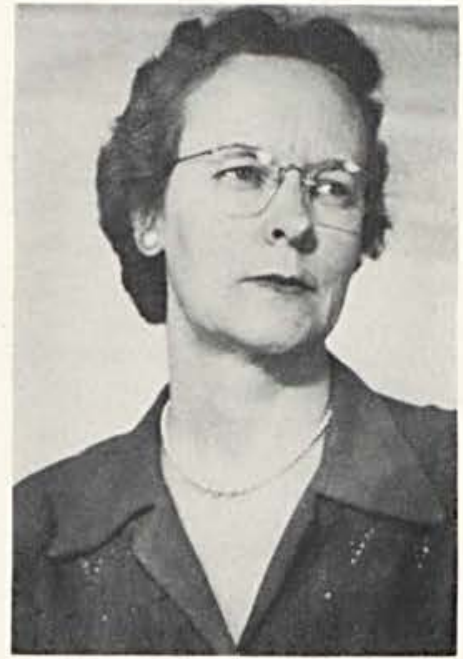

MRS. MENDEL BEATTIE DIETITIAN

LIVIA CHECK

LIBRARIAN

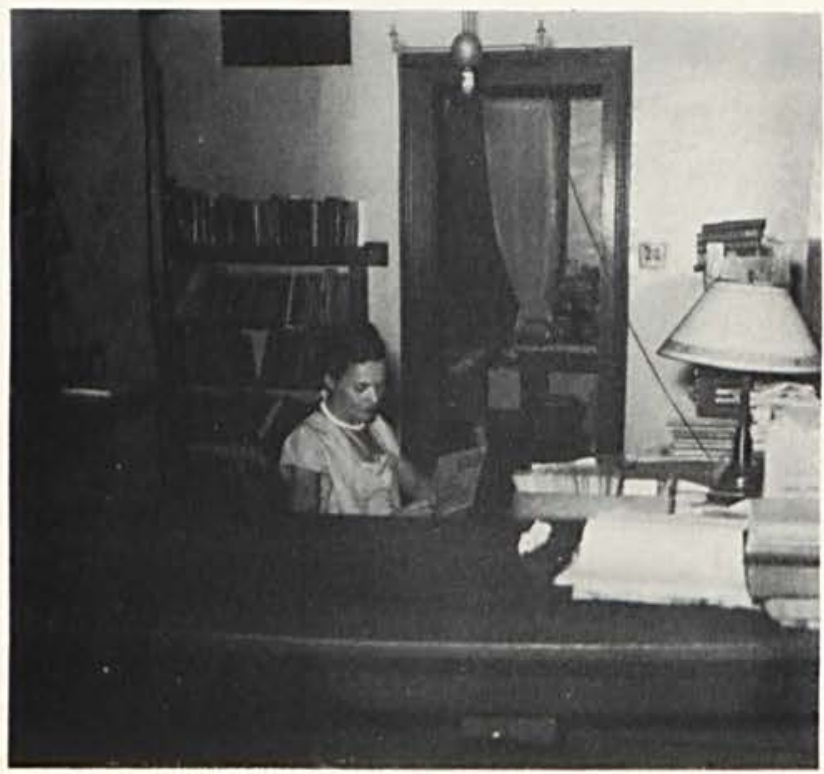




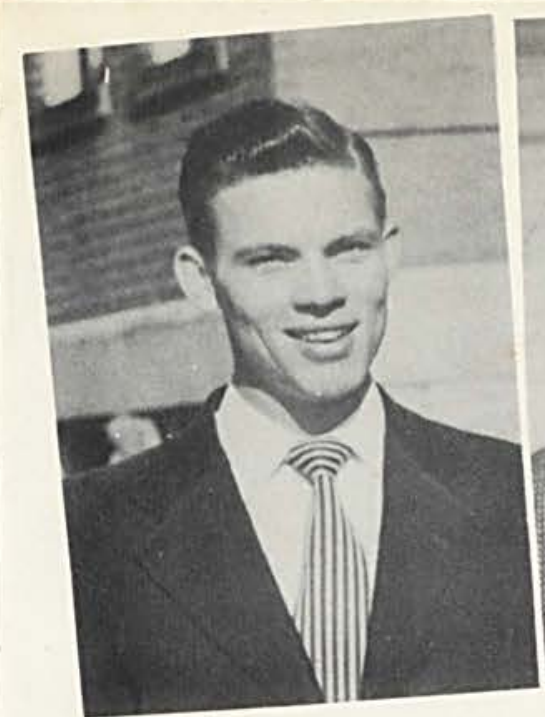

RAY THOMPSON

B.S. IN ED. SCIOTOVILLE, OHIO

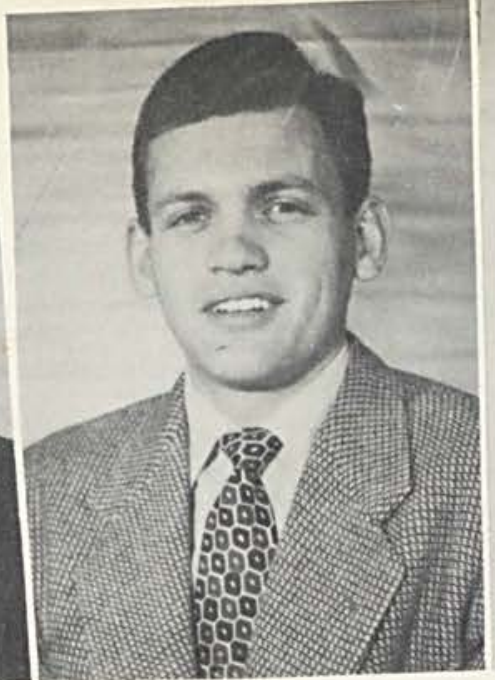

KENNETH WILBURN

A.B.

CEDARVILLE, OHIO

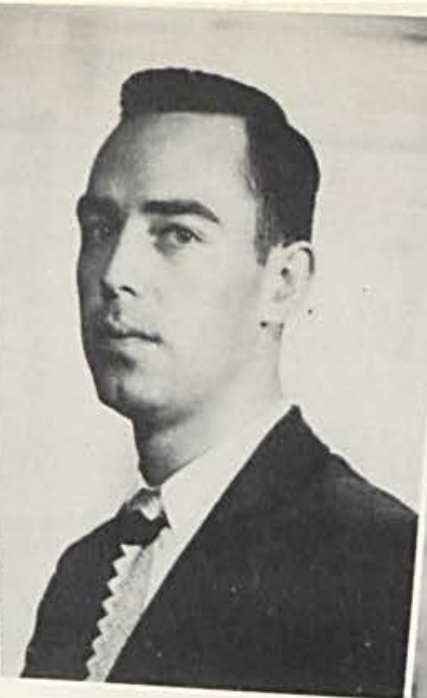

KENNETH HUFFMAN

B.S. IN ED.

CEDARVILLE, OHIO

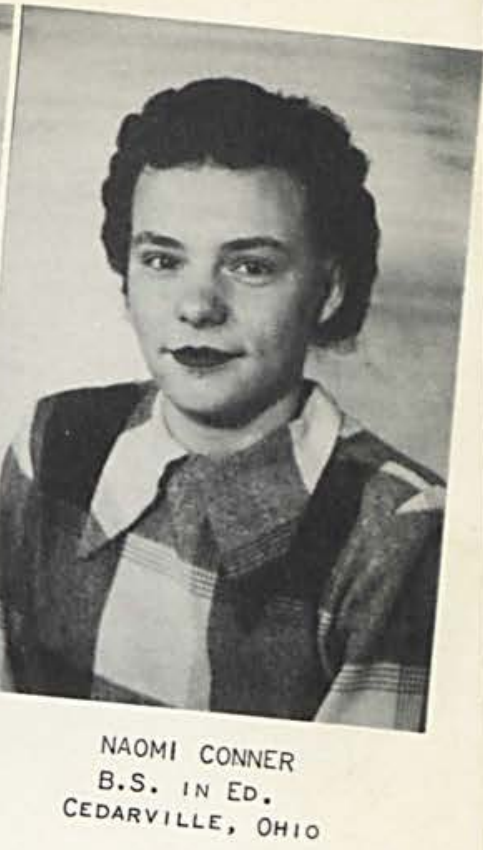

Graduating Class Of 1950

CLASS OFFICERS

President . . . . . . . . Kenneth Wilburn

V. President . . . . . . . . Kenneth Huffman

Secretary . . . . . . . . . Ray Thompson

Treasurer. . . . . . . . . . Naomi Conner

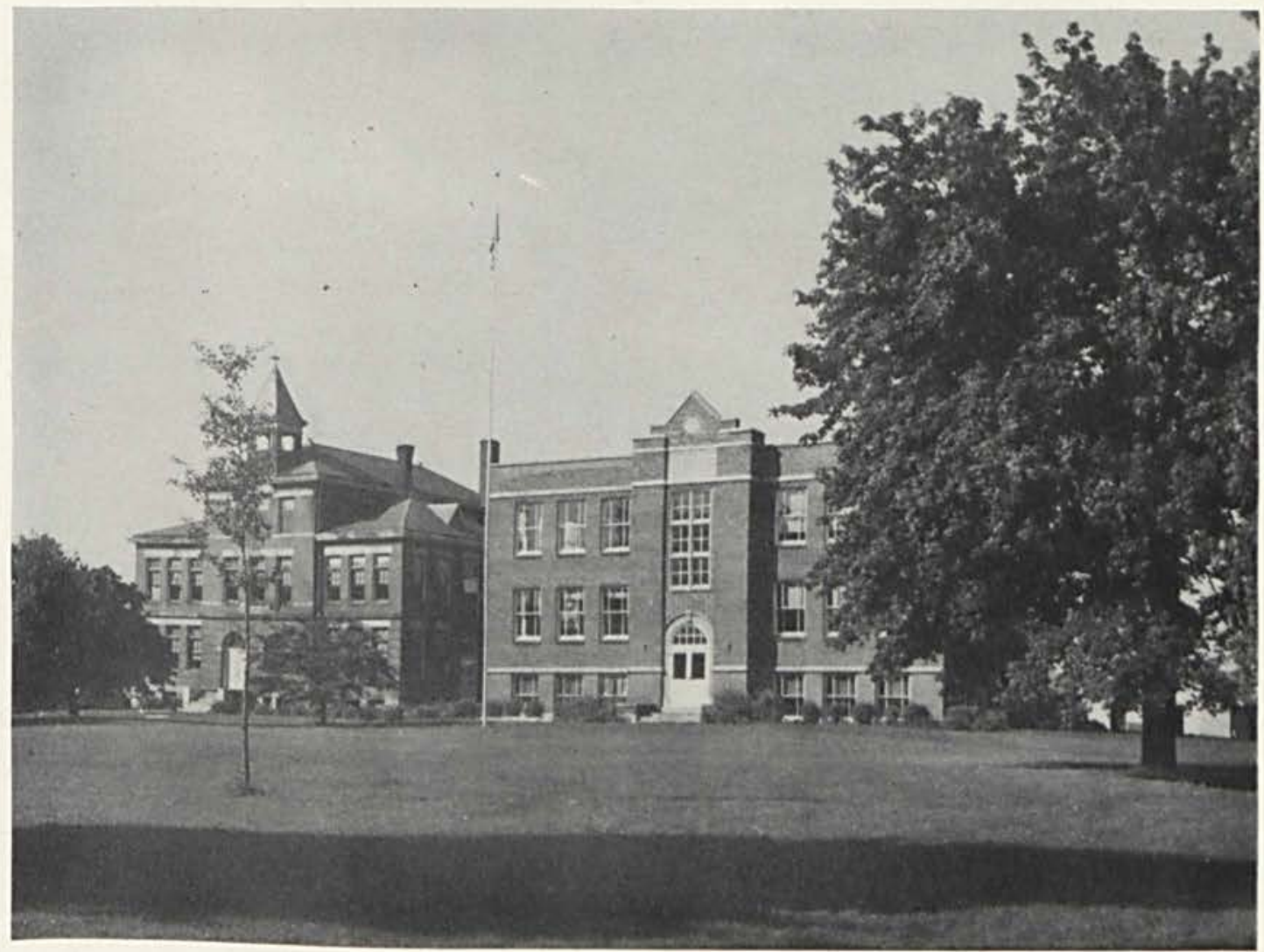

"Old C. C." 


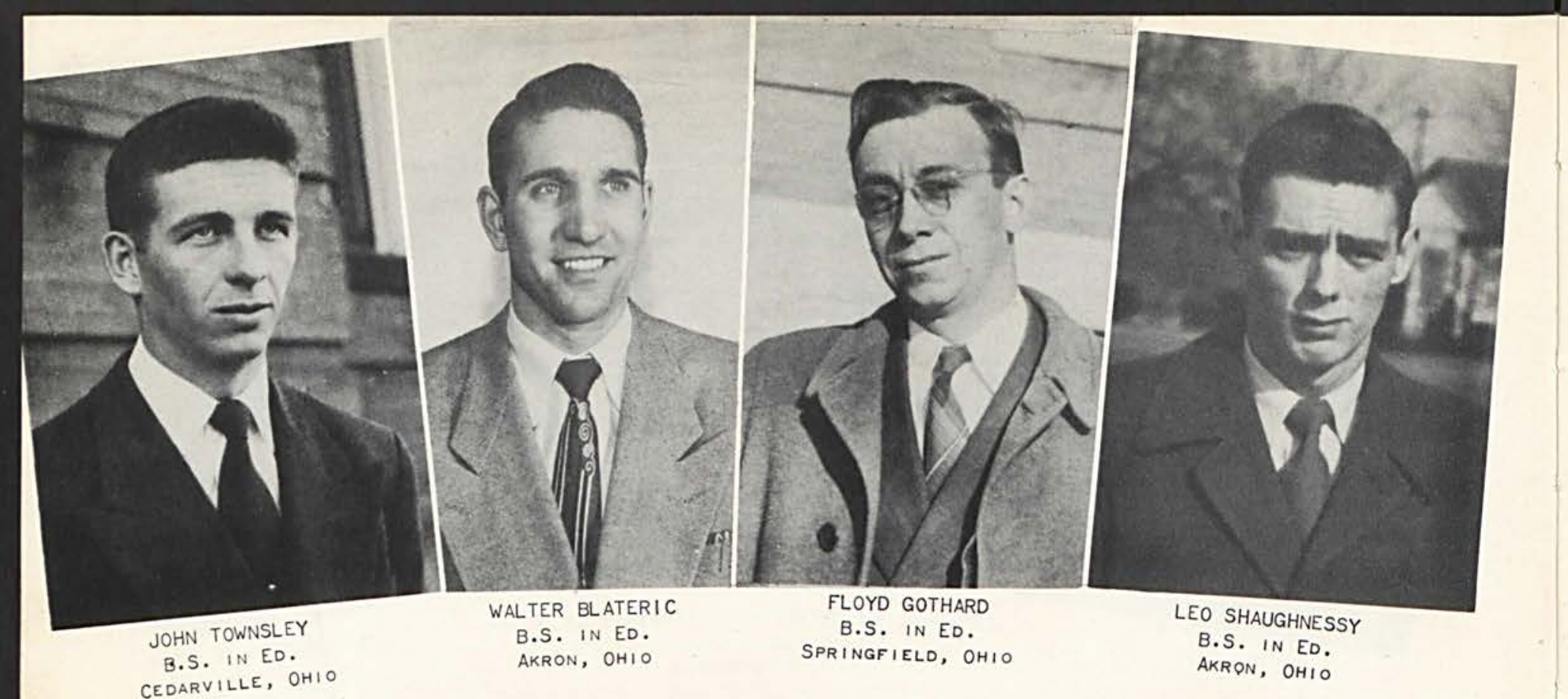

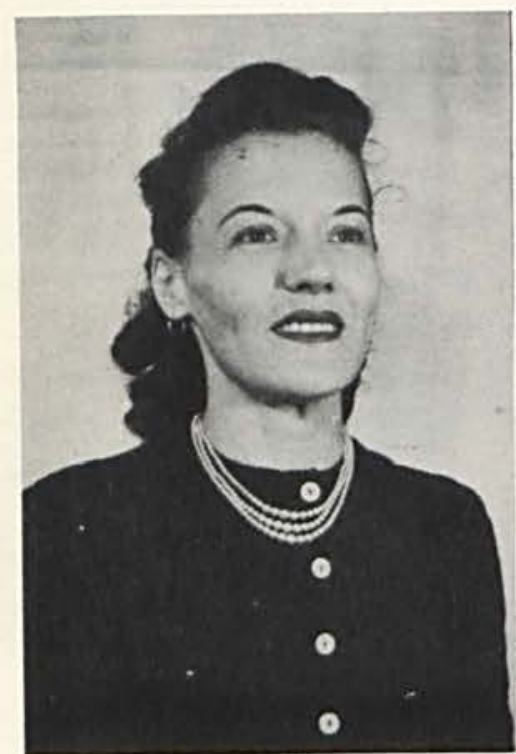

LIVIA CHECK

B.S. IN ED.

MOUNT UNION, PA.

ROBERT RADER

B.S. IN ED.

MANCHESTER, OHIO

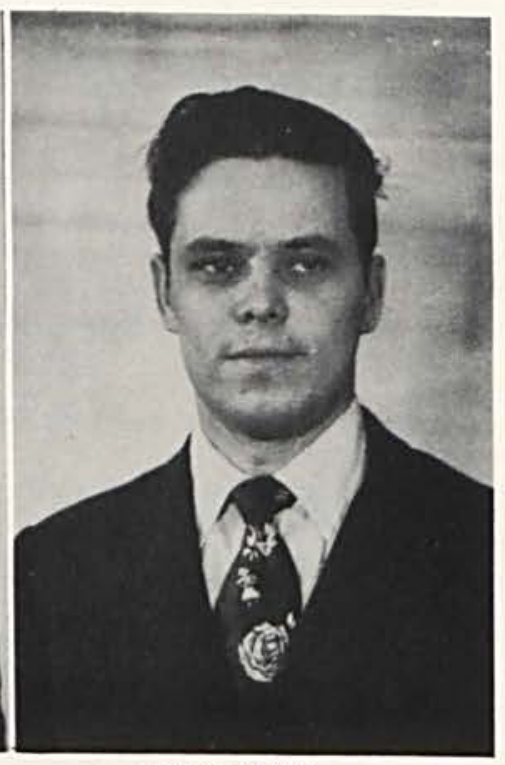

GEORGE WATT

B.S. IN ED.

DAYTON, OHIO

ERNEST STANLEY

B.S. IN ED.

PORTSMOUTH, OHIO
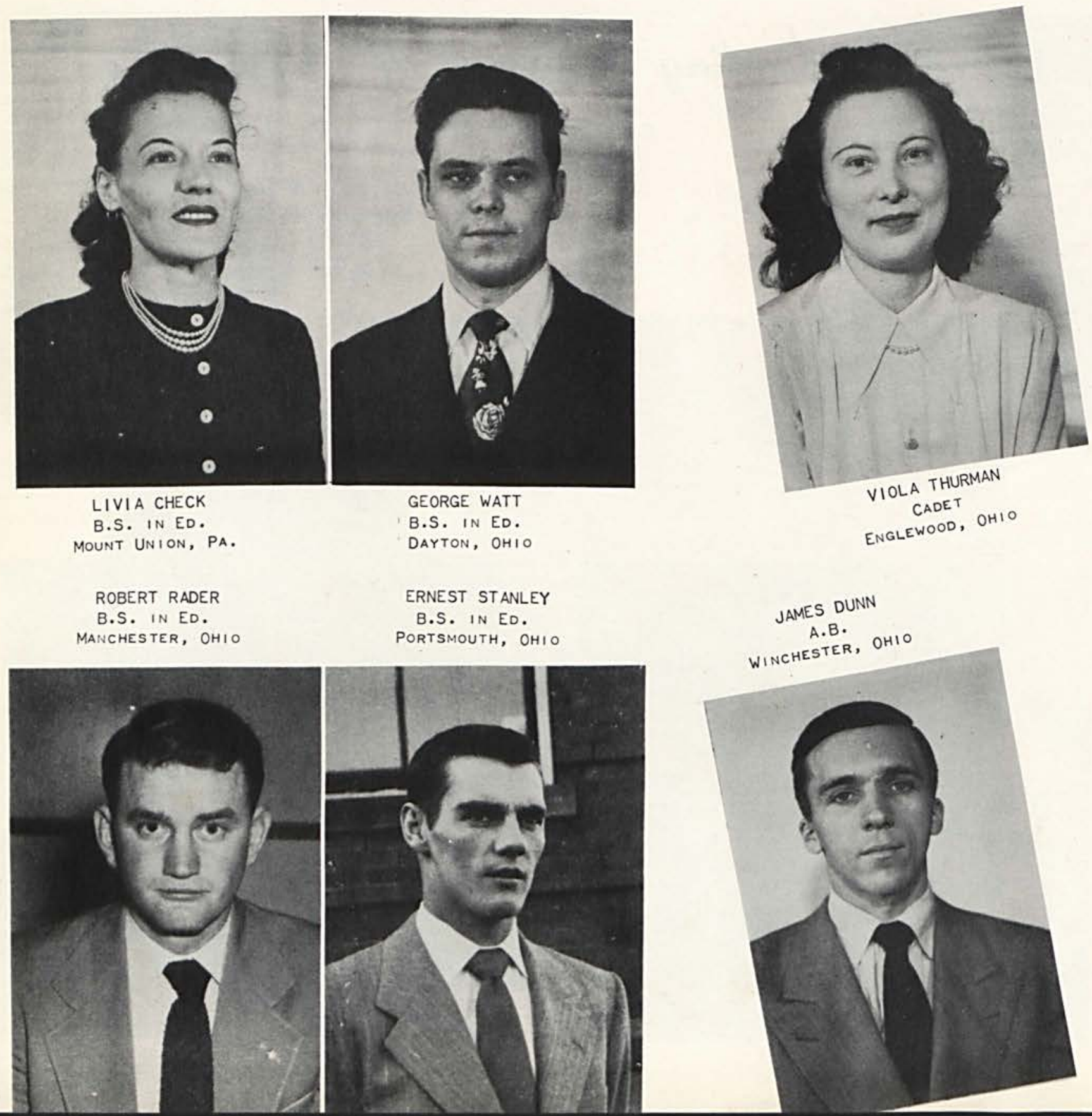

JAMES DUNN

A.B.

WINCHESTER, OHIO

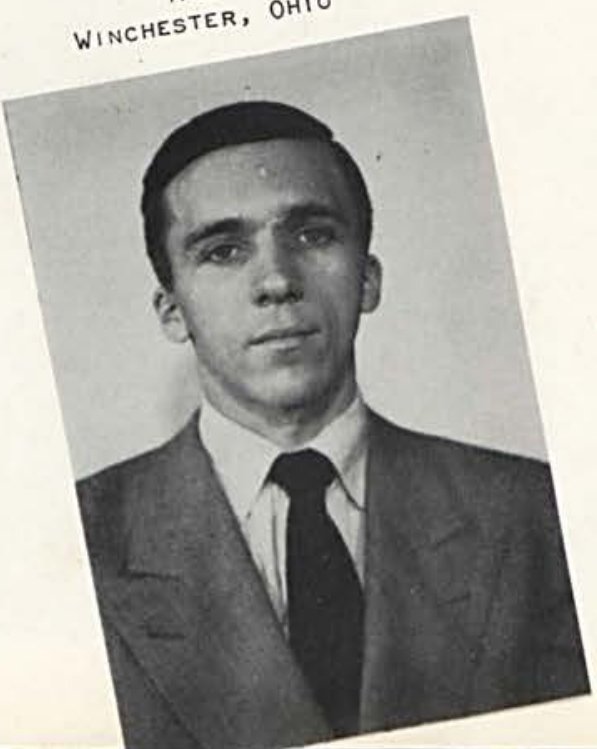




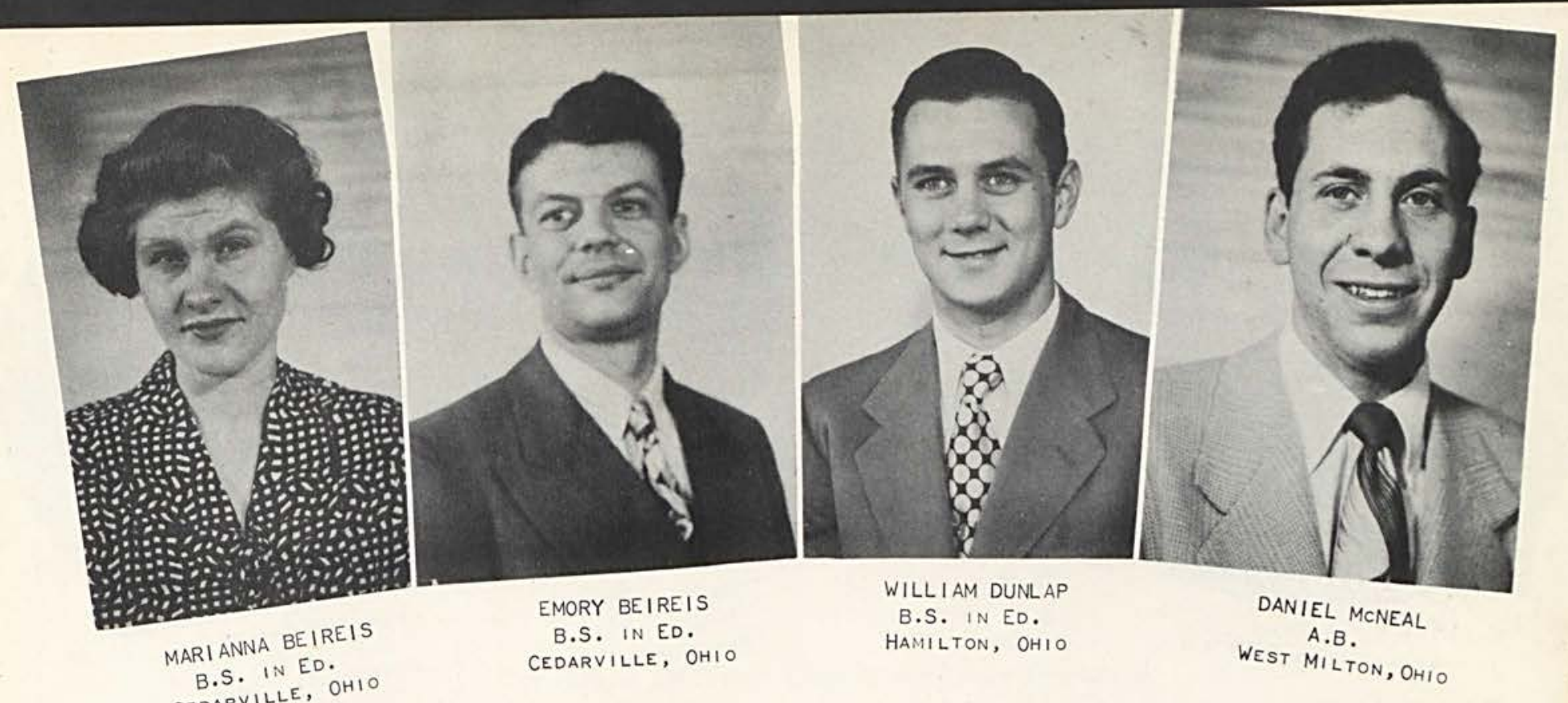

CEDARVILLE, OHI

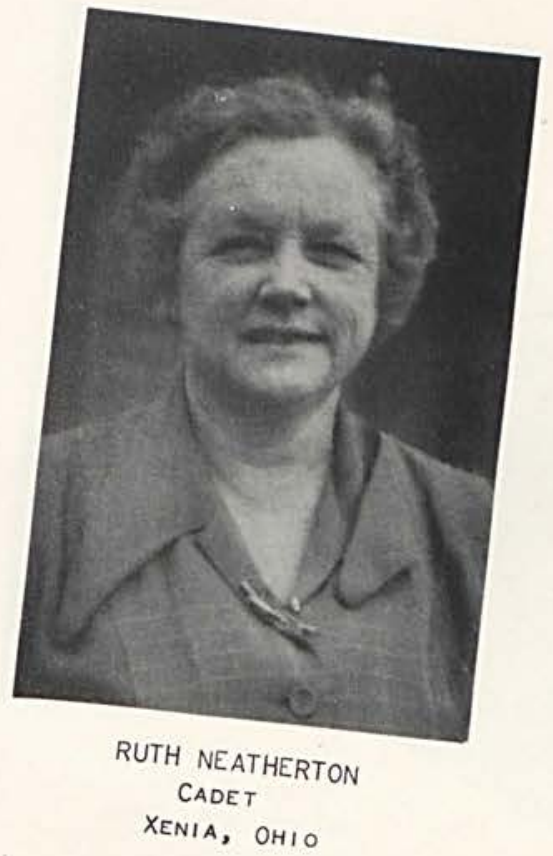

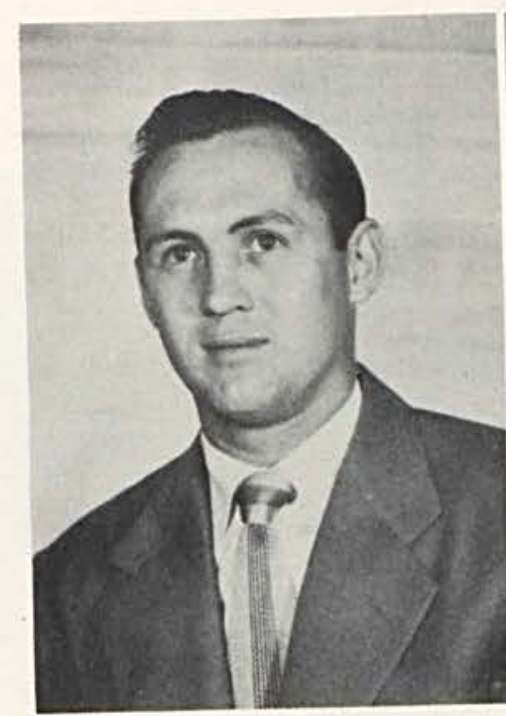

JAMES ROSS

B.S. IN ED.

SOUTH WEBSTER, OHIO

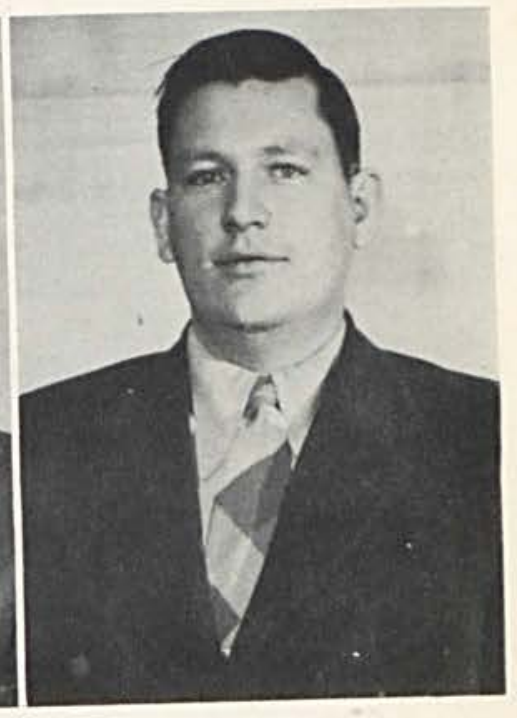

DONALD GEIS

B.S. IN ED.

JAMESTOWN, OHIO

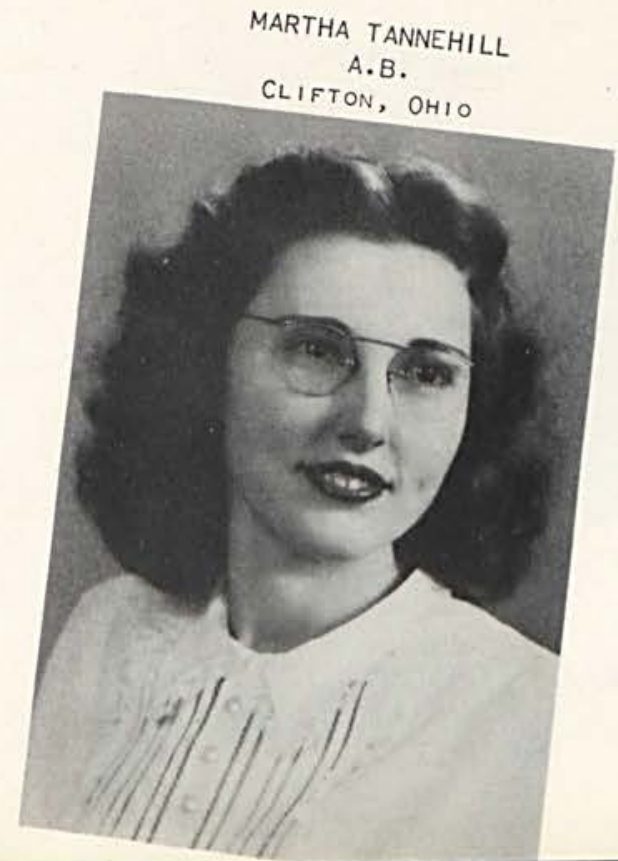

LOUISE HARNER CADET

XENIA, OHIO

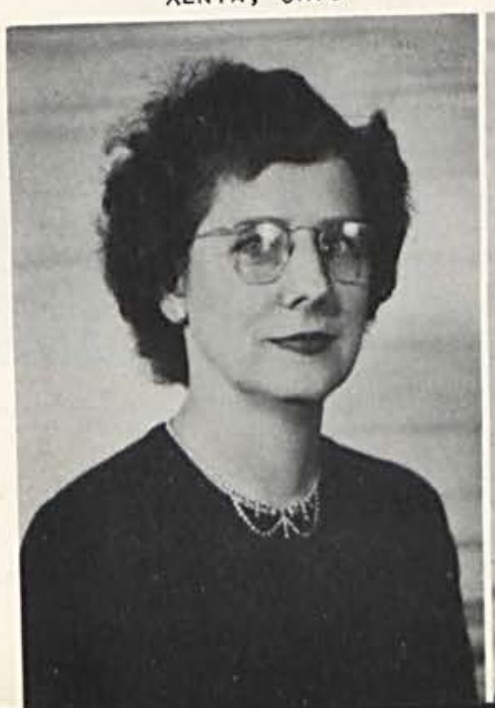

EDITH RUTAN

CADET

MECHANICSBURG, OHIO

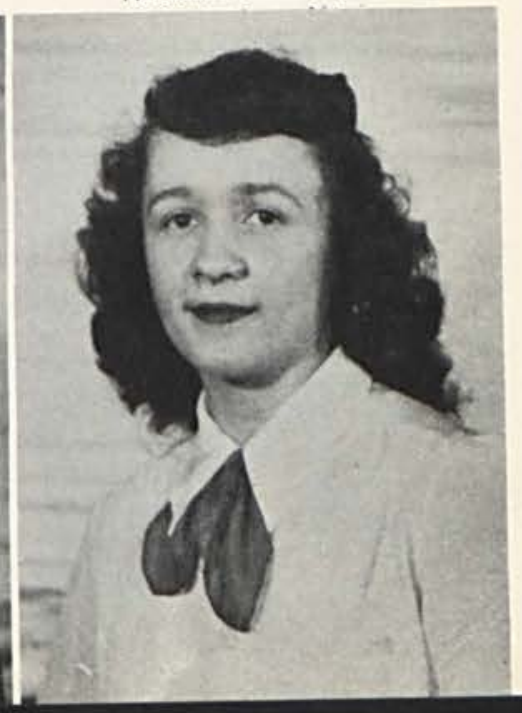




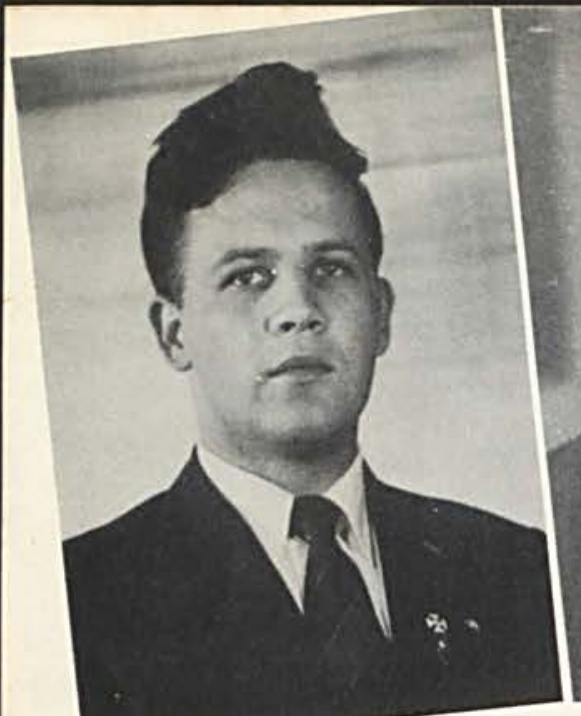

JOHN STEWART

B.S, IN ED.

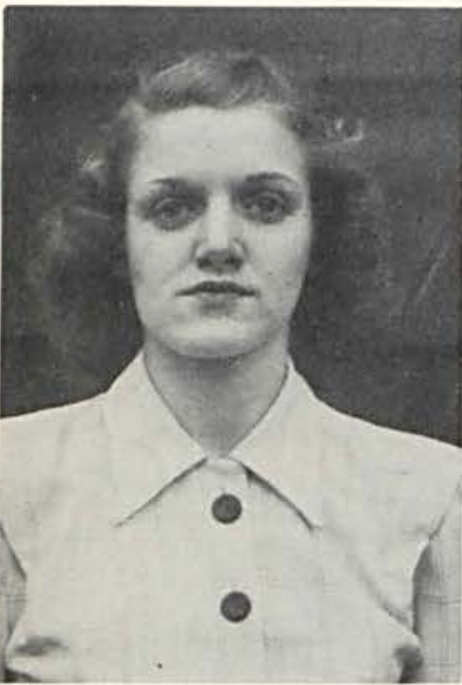

MARIE FISHER

A.B.

CLAYTON, OHIO
CEDARVILLE, OHIO

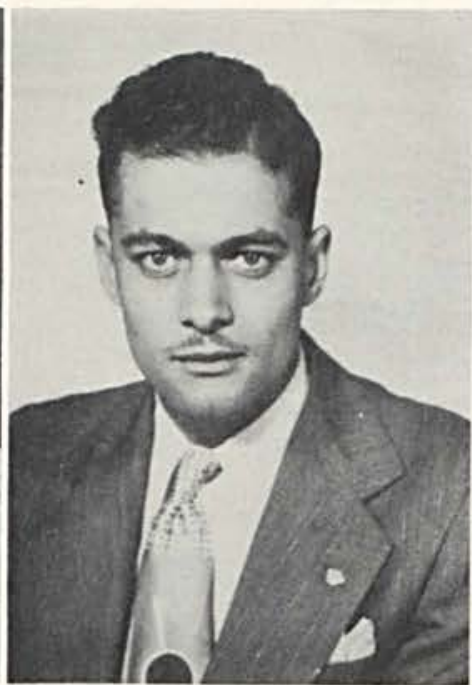

CARL JONES

B.S. IN ED.

CEDARVILLE, OHIO
WAYNE EVANS

WAYS. IN EO.

RIO GRANDE, OHIO
B.S. IN ED.
HAMILTON, OHIO

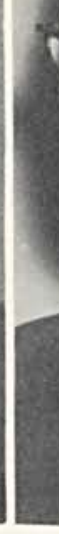

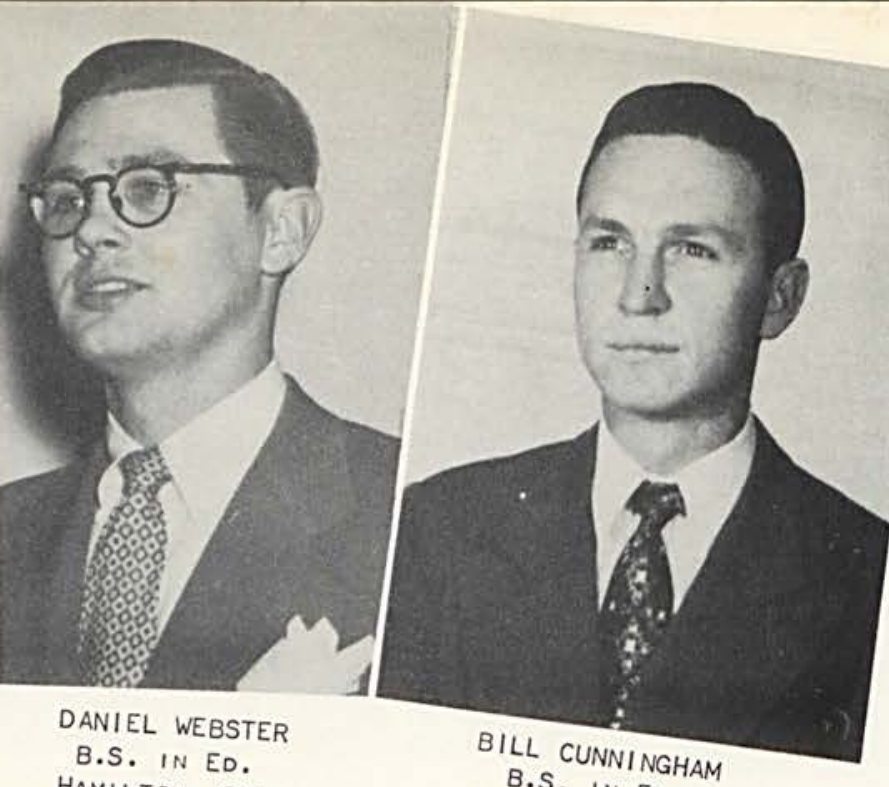

B.S.

PORTSMO IN ED.

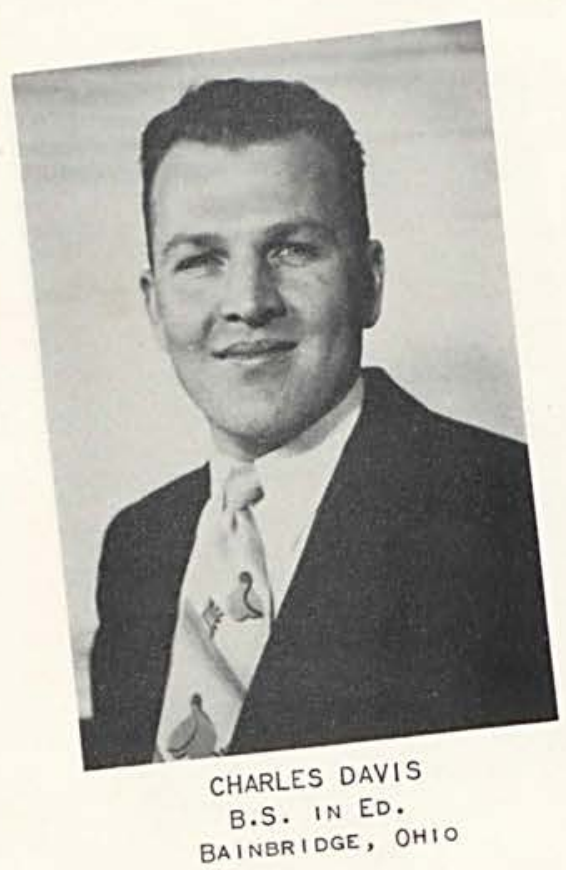

EUGENE SALLEE

B.S. IN ED.

A.B.

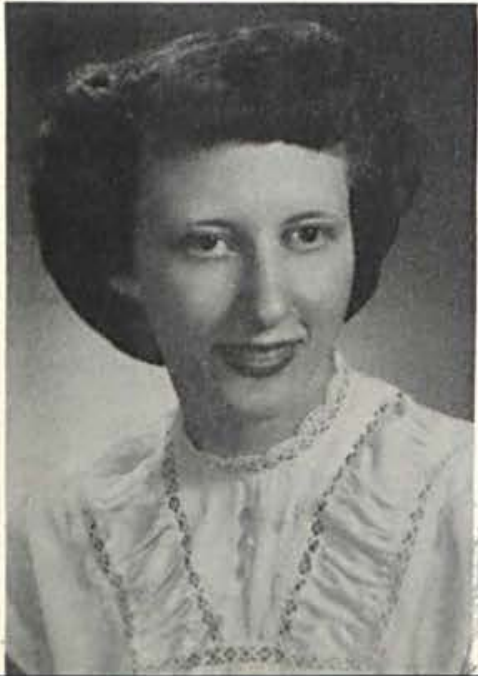

NEW BURLINGTON, OHIO

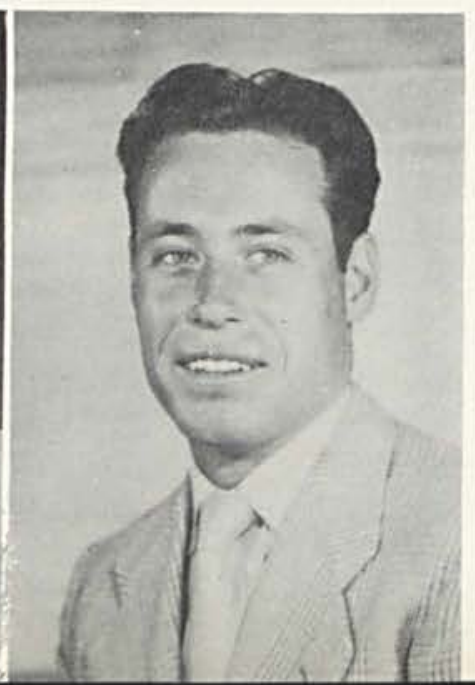

JAMES BURNS

A.B.

SCIOTOVILLE, OHIO

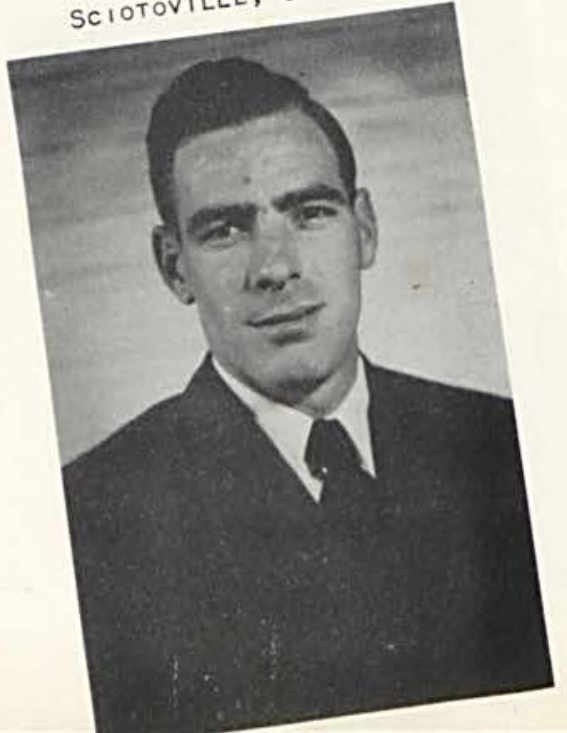



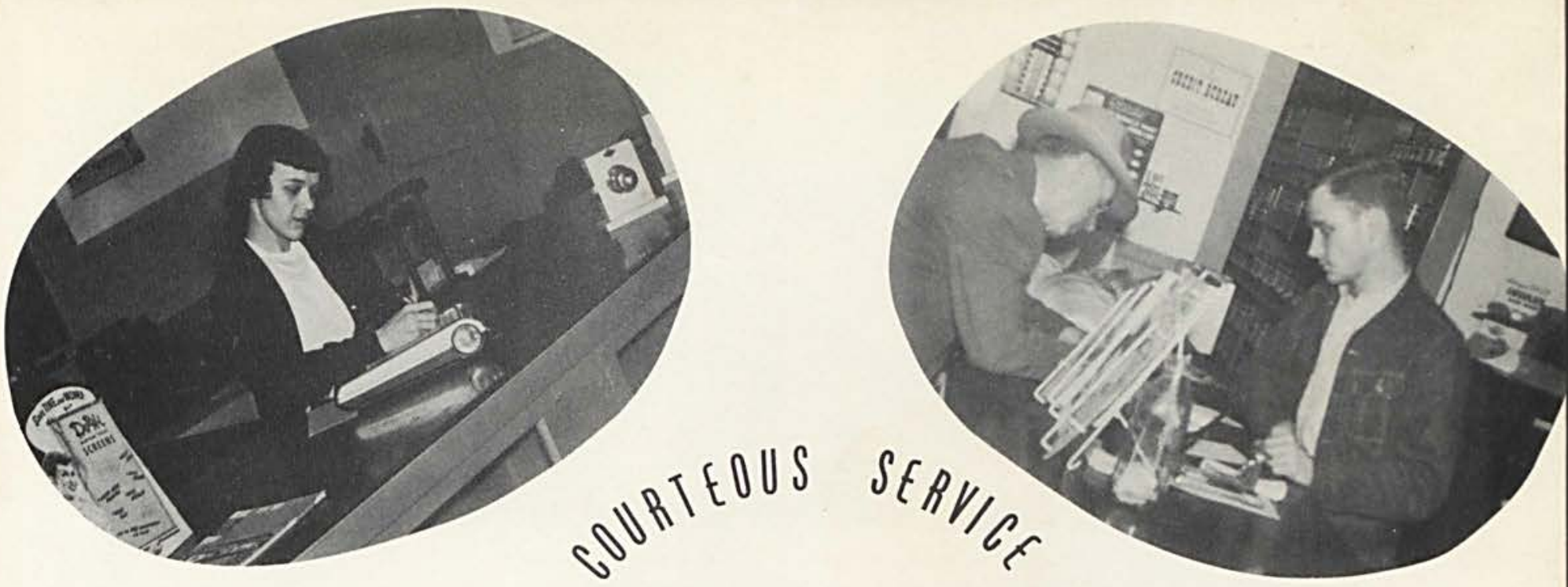

A Home Of Your Own Your Only Security

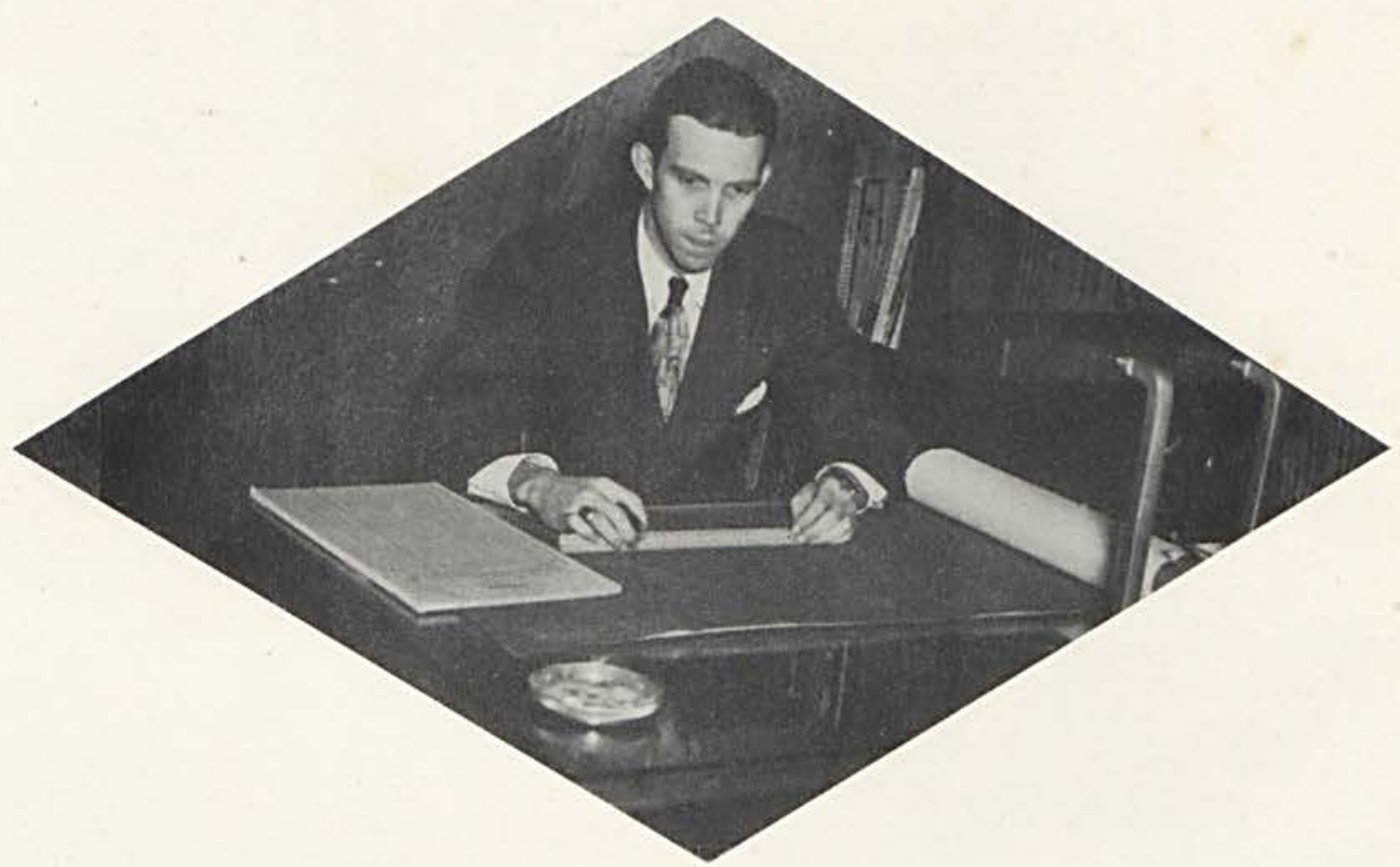

Home Planning Center

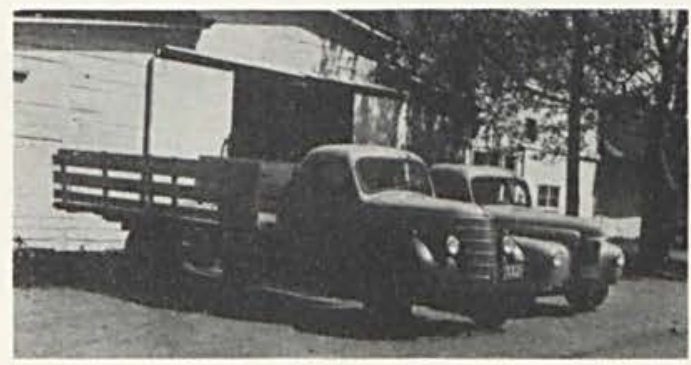

Prompt Delivery

CEDAR VILLE LUMBER CO. 6-1331

Cedarville, Ohio 



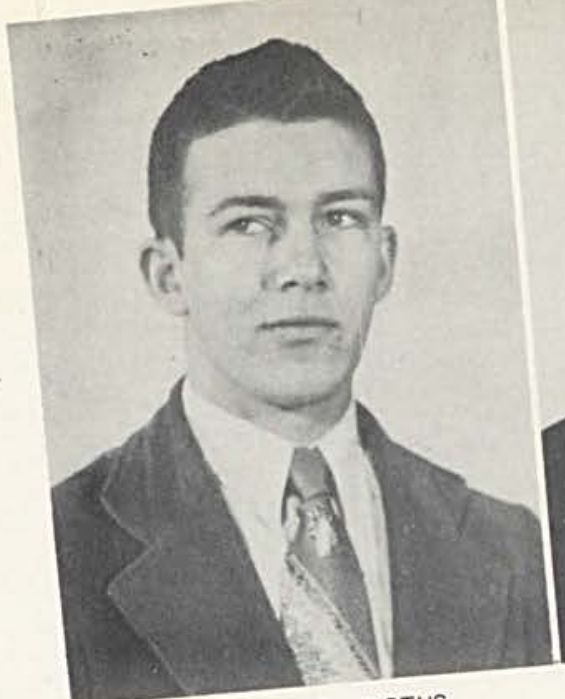

ALDON ARCHIE JUSTUS

B.S. IN ED.

SCIOTO FURNACE, OHIO

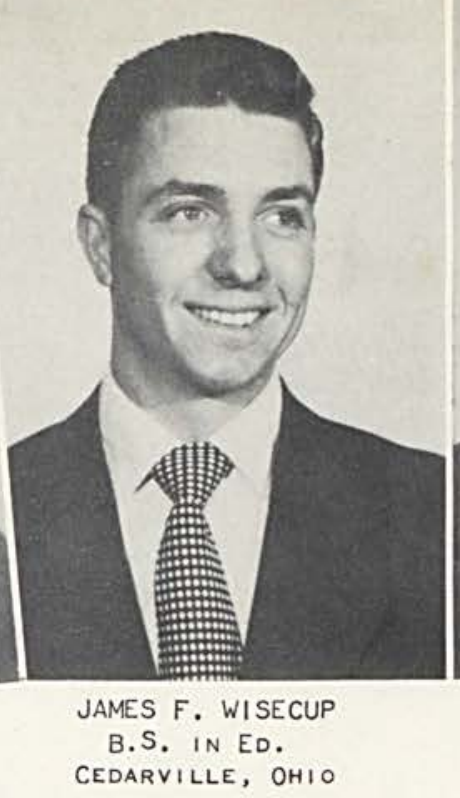

CEDARVILLE, OHIO

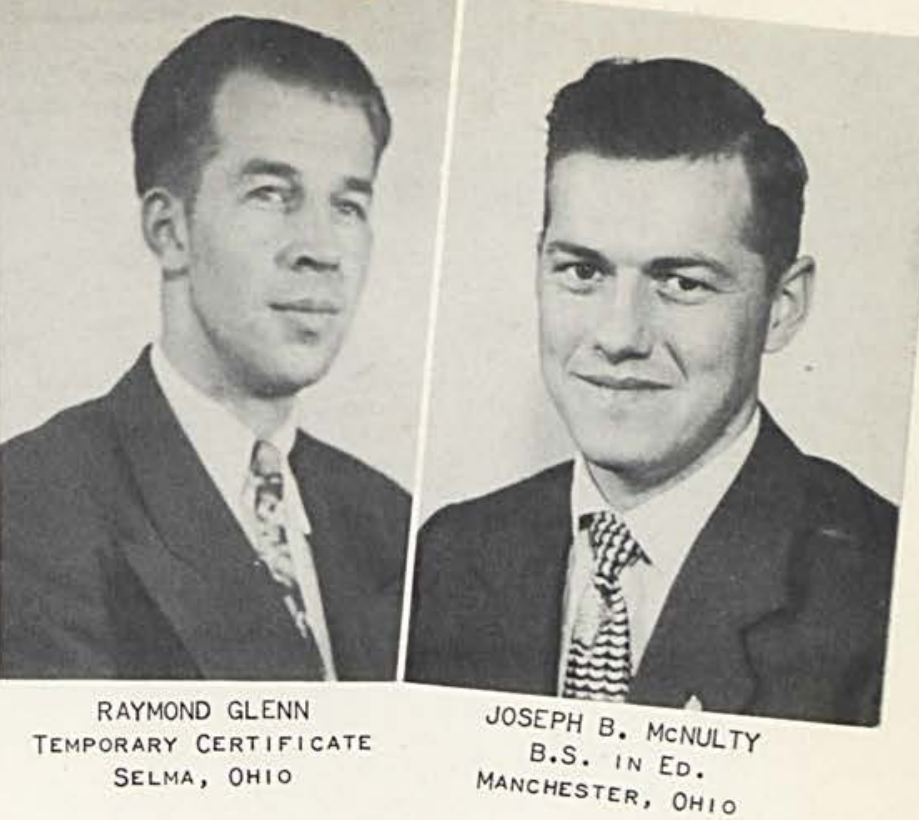

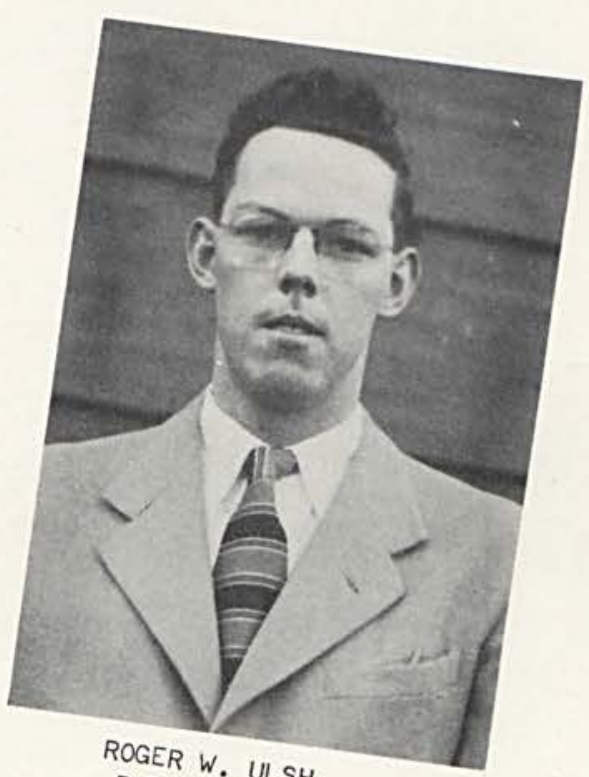

B.SR W. ULSH

CEDARV IN ED.

CEDARVILLE, OHIO

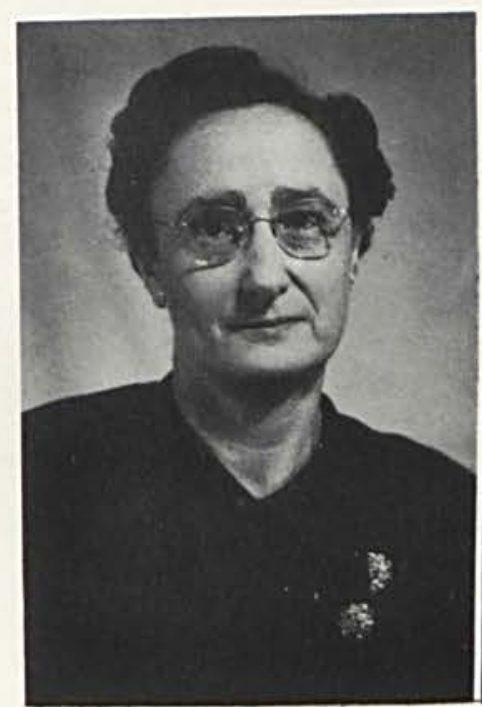

CLARA SQUIRES

KINDERGARTEN PRIMARY CERT. YELLOW SPRINGS, OHIO

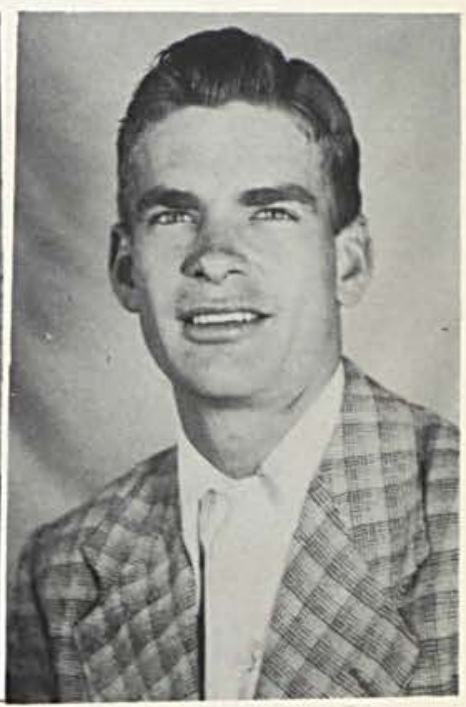

CLAY L. COTTLE

B.S. IN ED.

SCIOTOVILLE; OHIO

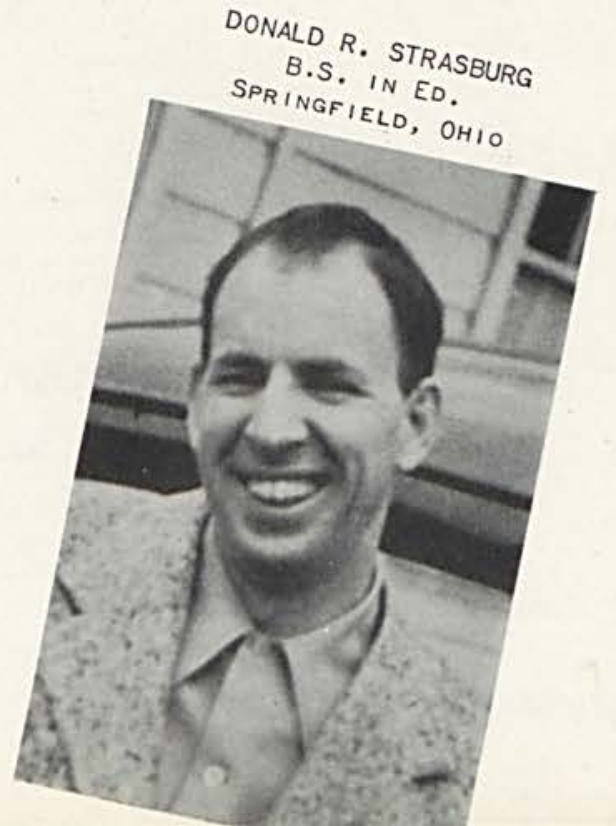

BION BRADBURY

A.B.

CEDARVILLE, OHIO

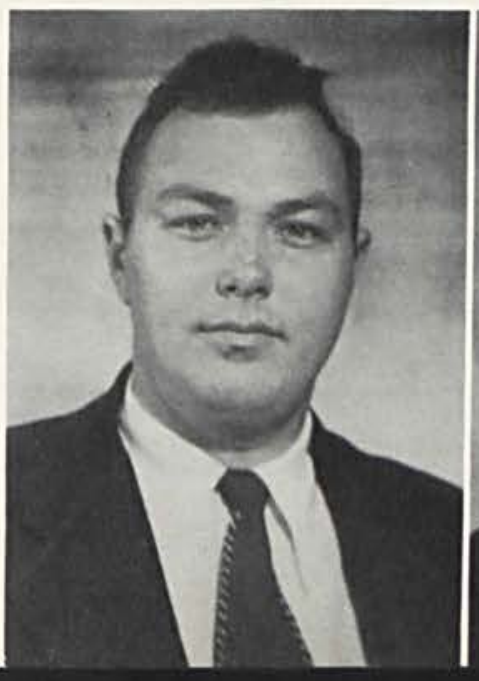

JAMES LEWIS

B.S. IN EDUCATION

OAK HILL, OHIO

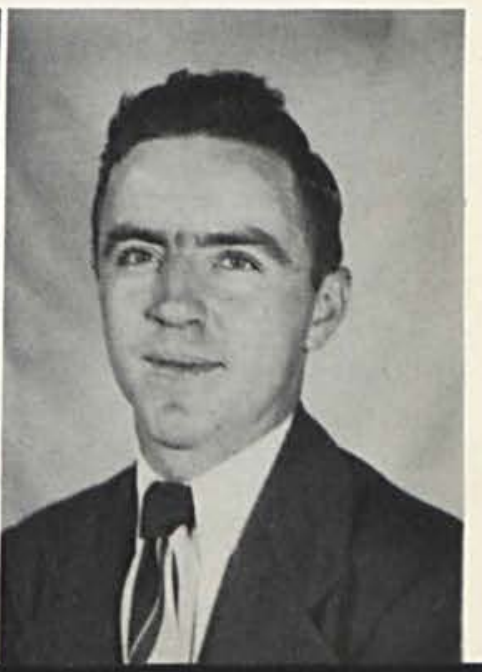




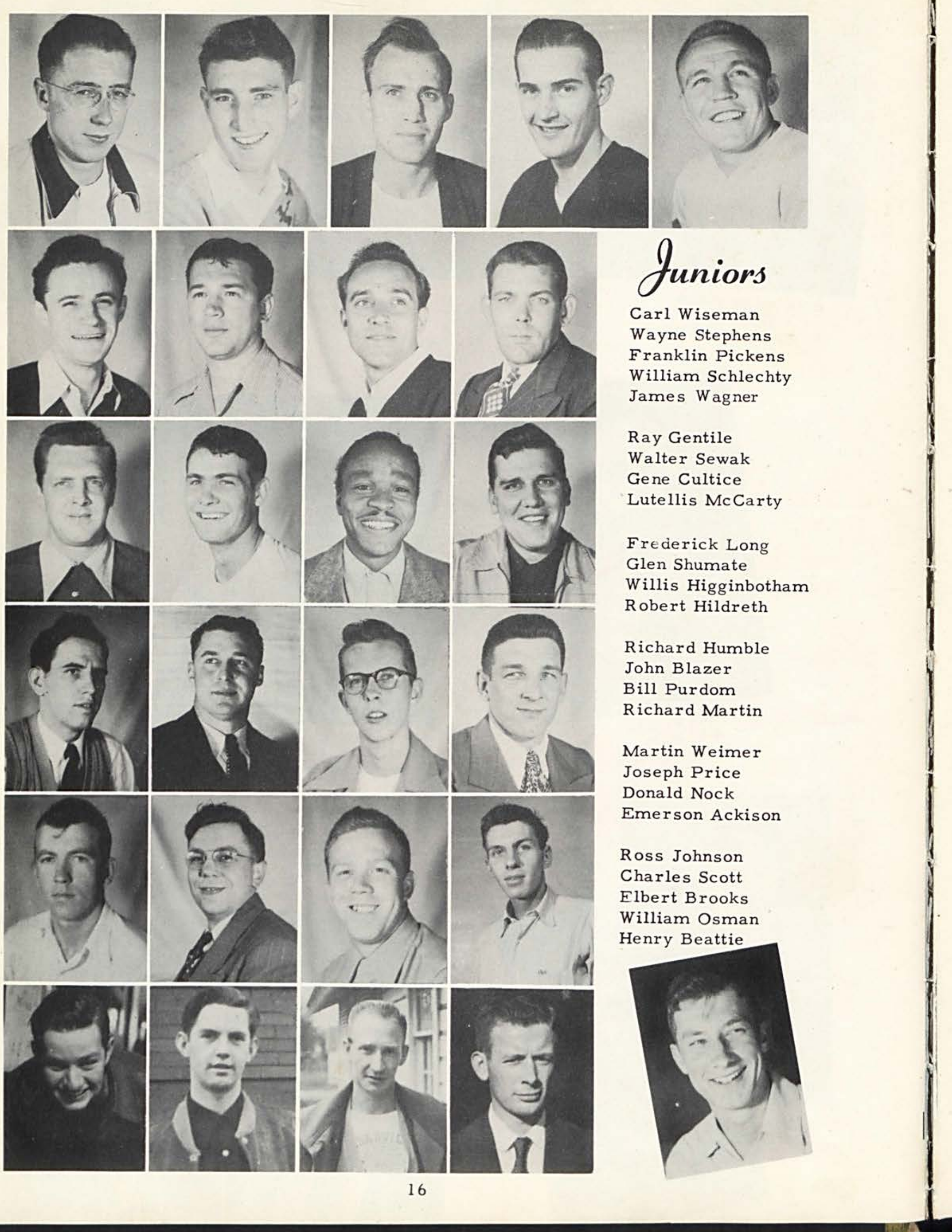



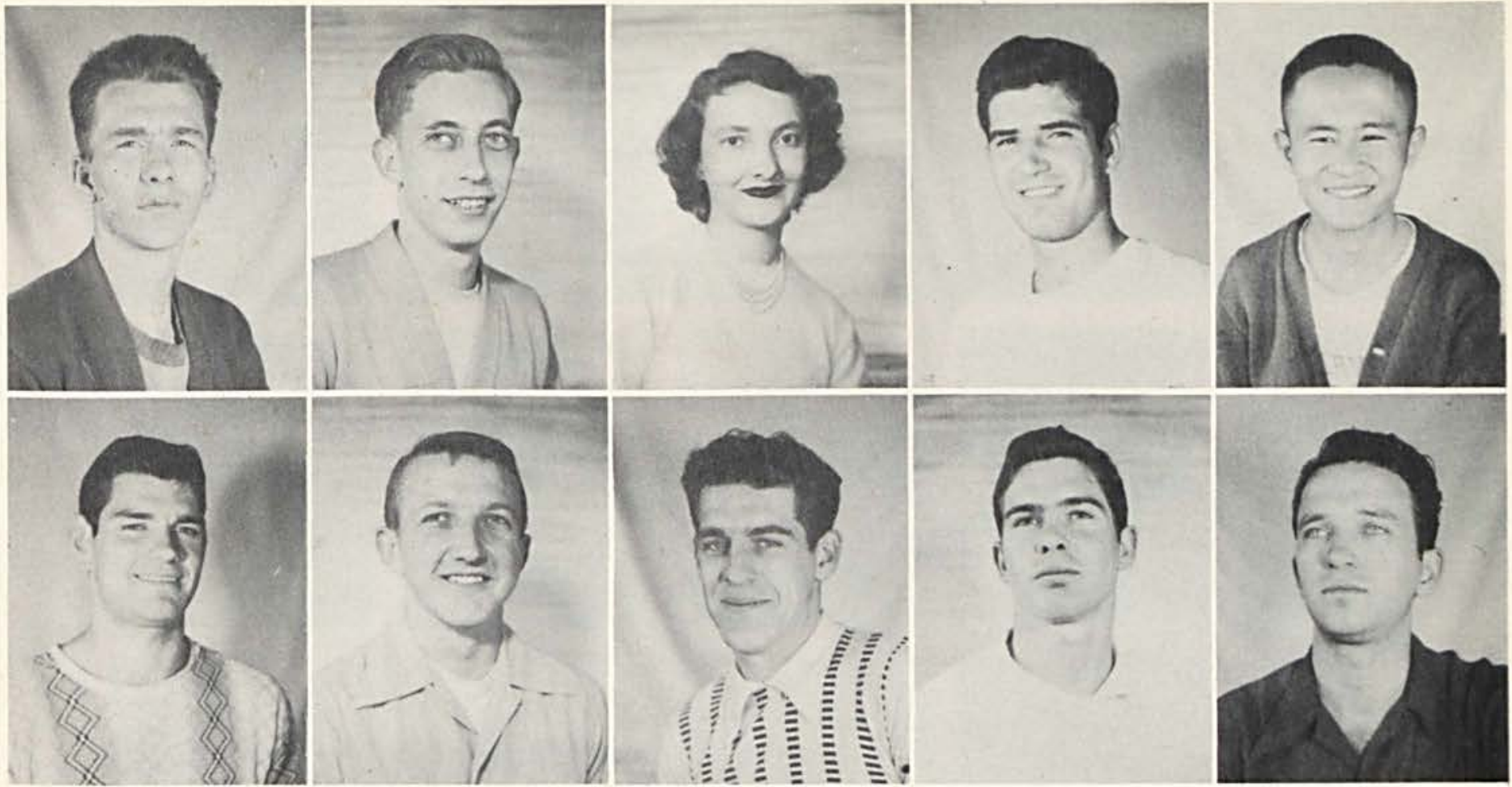

\section{Sophomores}

Thomas Bellville

East Fultonham,O.

Paul Fiedler, Minerva, O.

Geraldine Powell

Huntington, West Va. Dean Harner, Wilmington, $\mathrm{O}$. Harman Lum, Hamilton, $O$.

David King, Elyria, O.

David Spitzer, Tipp City, O. Robert Peters, Osborn, O.

Earl Downs, Wheelersburg, O.

James Hunter, Oak Hill, O.

John Snowden, Winchester, Ky. Warren King, Oxford, O.

Charles Scott, Jr., Enon, O.

Tom Osborne, South Point, $\mathrm{O}$. Robert Miller, Bellefontaine, $O$. Ray Carter, Gallia, O.

Eugene Fisher, Waterbury, Vt. Richard Smith, Xenia, O. James Lynd, Ironton, $\mathrm{O}$.
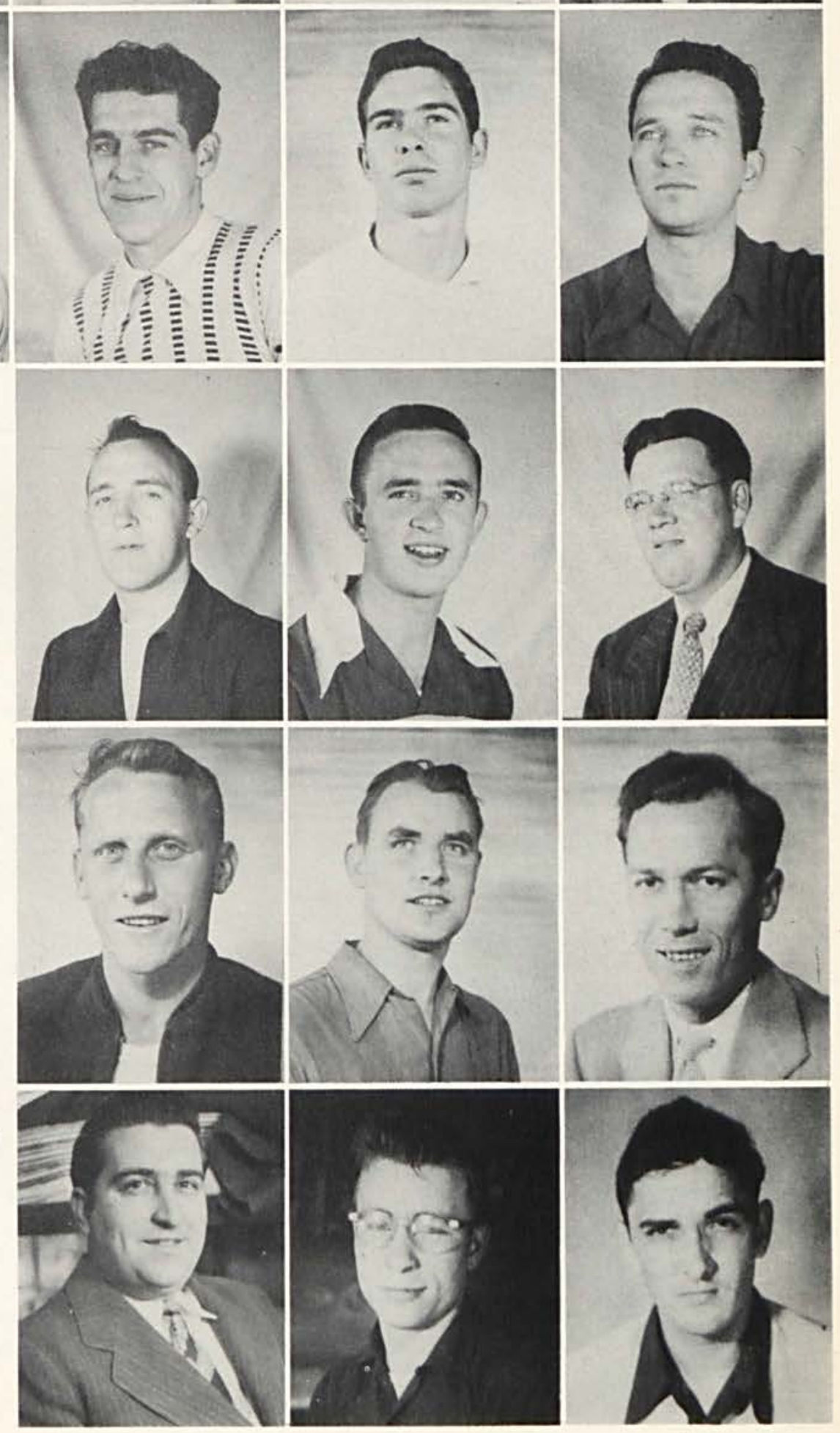

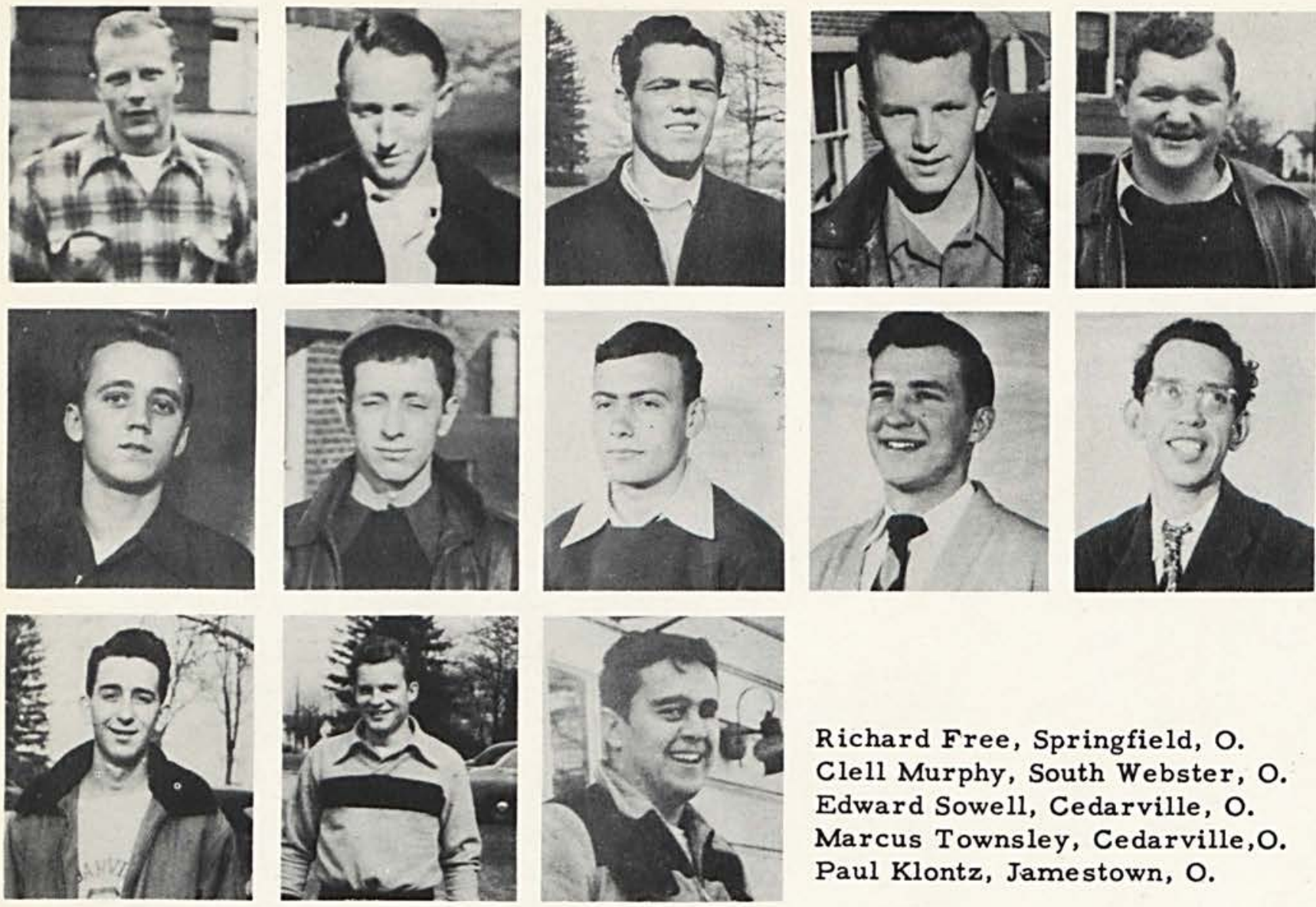

Richard Free, Springfield, $O$. Clell Murphy, South Webster, O. Edward Sowell, Cedarville, O. Marcus Townsley, Cedarville,O. Paul Klontz, Jamestown, O.
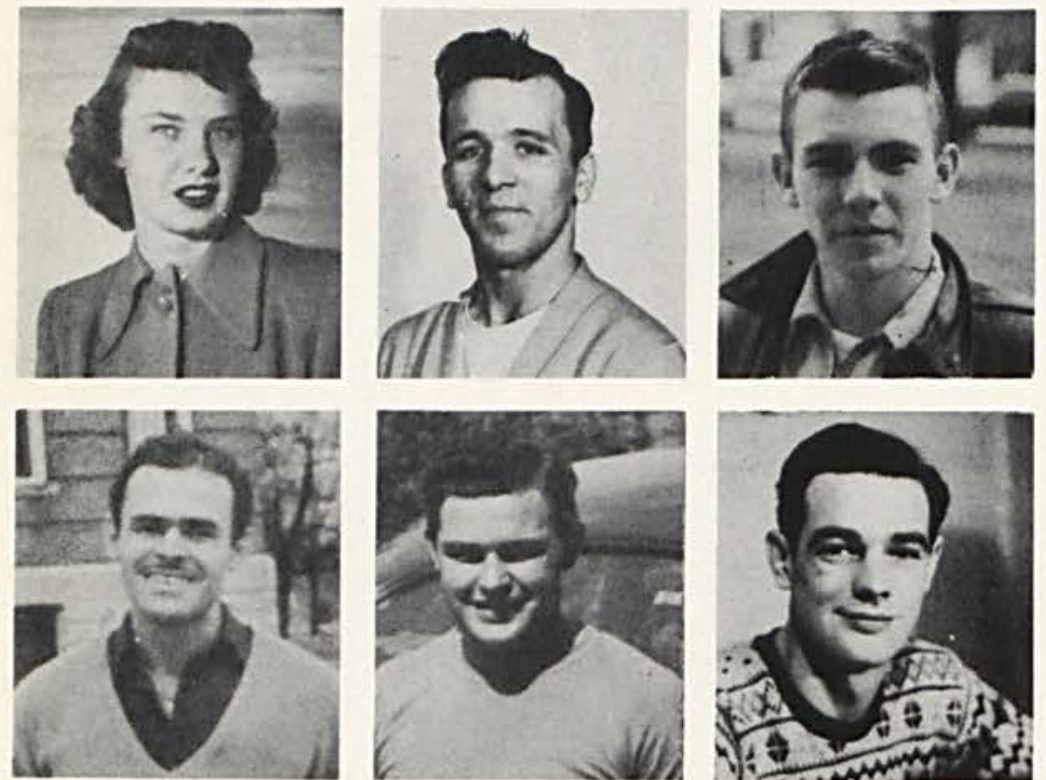

Robert Stafford, Jamestown, O.

Norman Howard, South Webster, O. Ted Sutton, Weirton, West Va. James Shaffer, Minerva, O. Myers Bost, Springfield, O.

Roger Charles, Cedarville, $O$. Garland Cox, Manchester, $O$. Mike DiStaola, Hamilton, 0 .

Mary Louise Stormont, Cedarville, 0. Paul Dunn, Winchester, $O$.

Douglas Cultice, Cedarville, 0 .
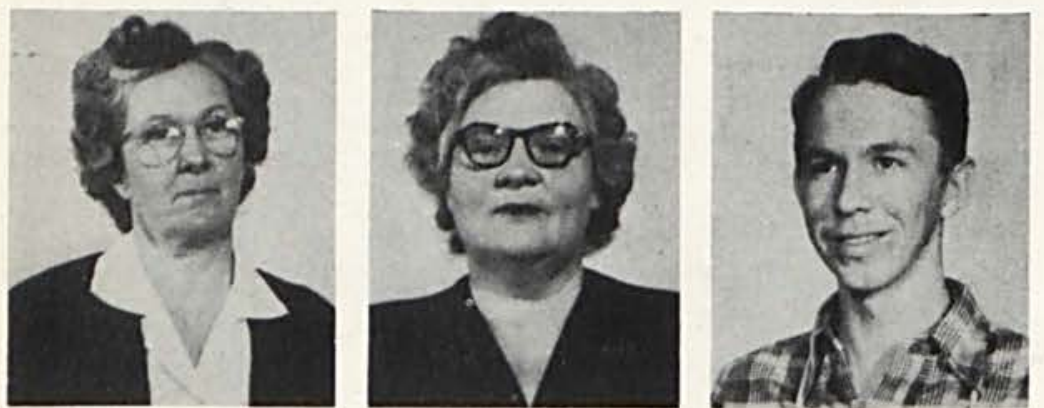

Reuben Padro, Porto Rico

Gerald Bradford, Springfield, O.

Charles Rader, Manchester, $O$.

Pauline Powers, Cedarville, 0 . Mary Hanna, Cedarville, 0.

Jack Bellville, East Fultonham, O. 
Dick Wright

Cedarville, O.

Floyd Butts

Rosewood, O.

Don Swank

Dayton, O.

Byron Wallace

Lawrenceville, 0 .
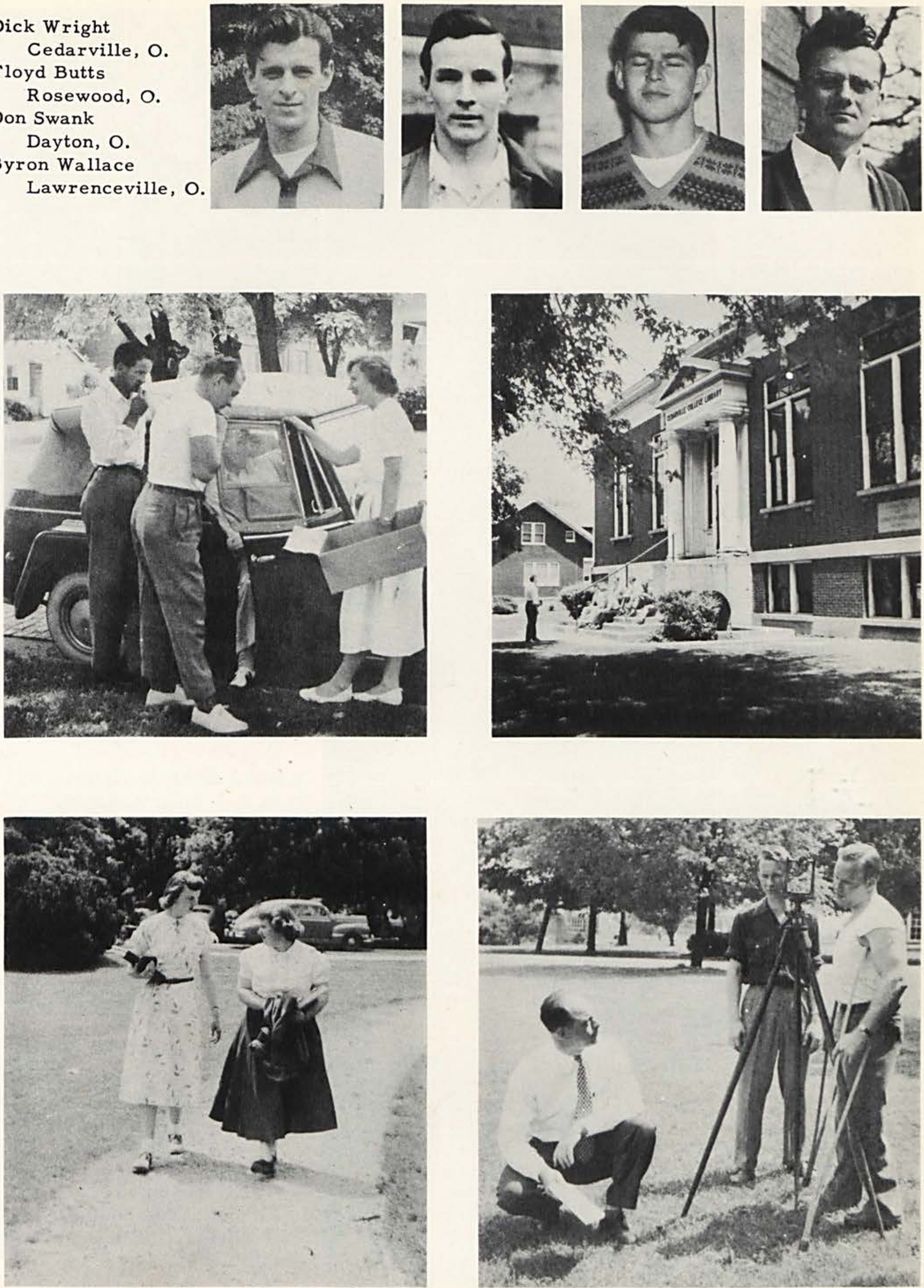


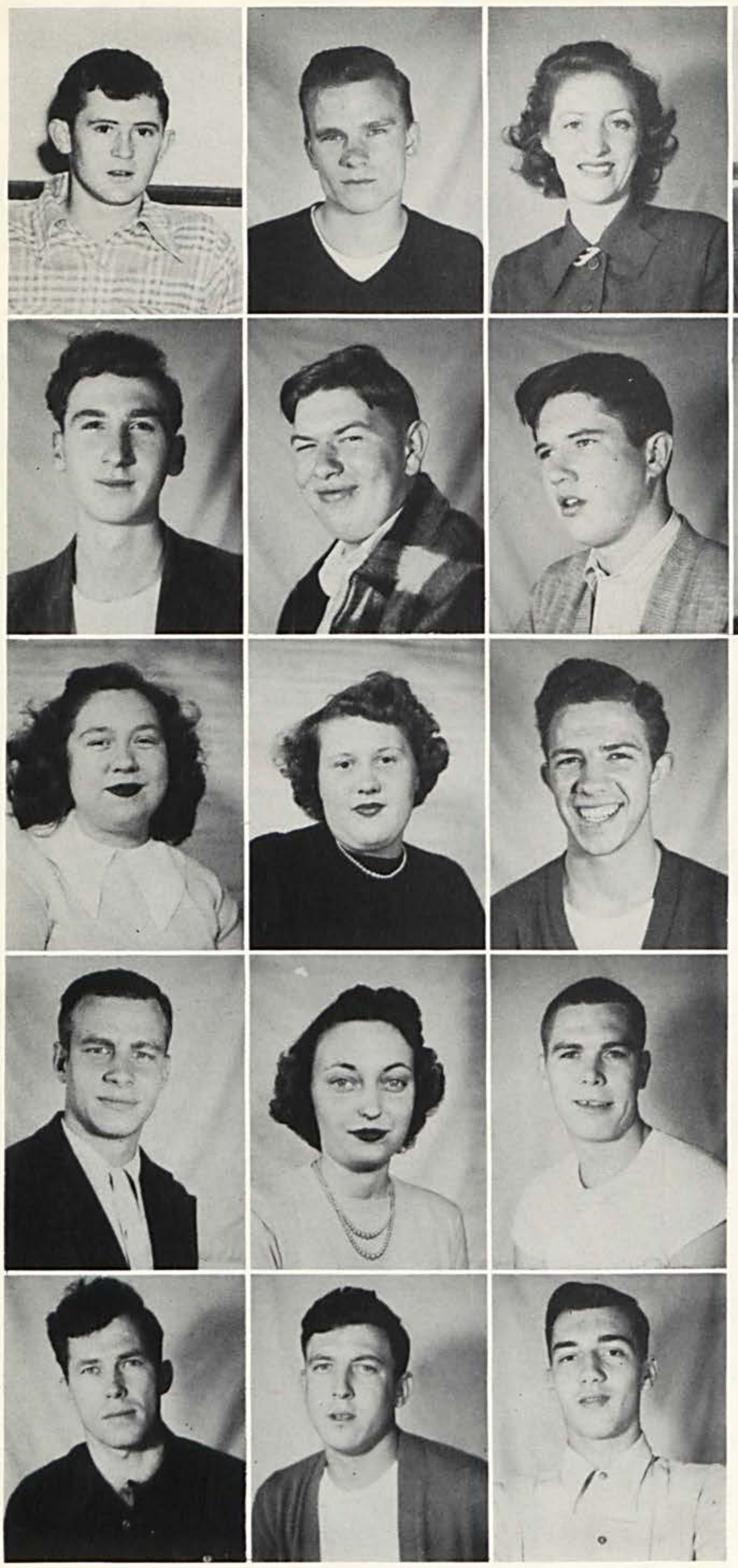

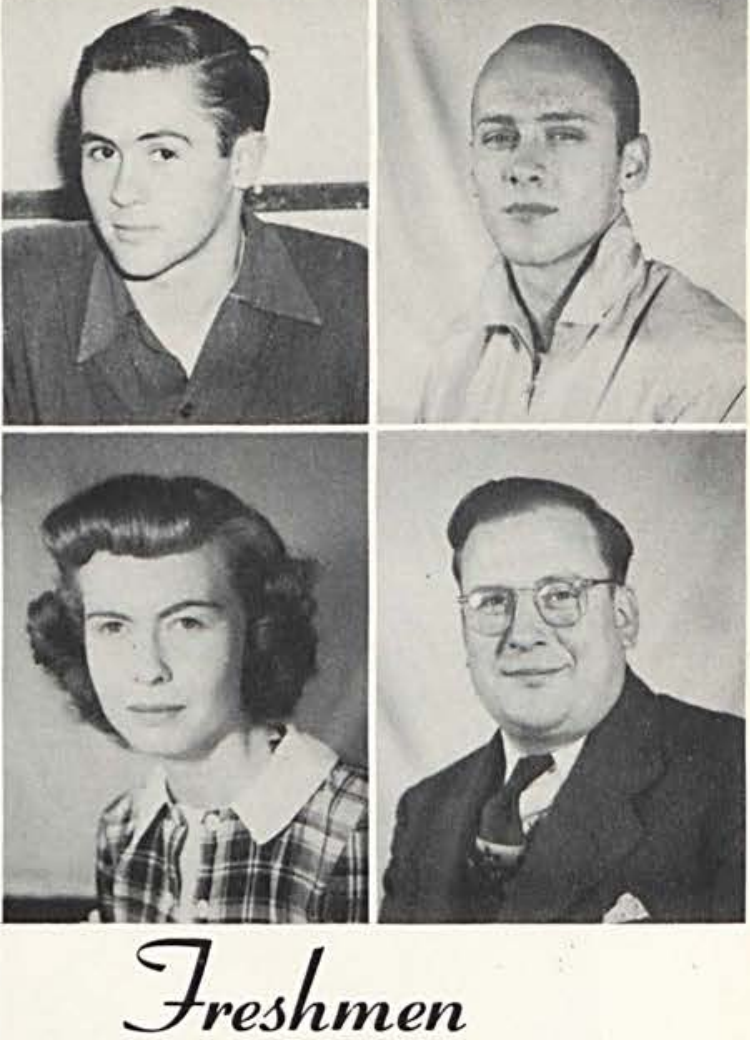

Elmo Ross, South Webster, O. Kenneth Woods, Millvale, Pa. Naoma Newman, Xenia, O. Charles Ross

South Webster, O.

Lowell Thompson

Portsmouth, O.

Edward Brill, Jamestown, O. John Reynolds, Xenia, O.

Richard Coeffelt, Xenia, O. Mary Francis, Versailles, O. Kenneth Peck, Springfield, O.

Nancy Guilfoyle

Manchester, $\mathrm{O}$.

Marcelyn Girnus,

North Lewisburg, 0.

Max Kisor, Portsmouth, O.

Richard Albrecht,

Portsmouth, O.

Mary French, Jeffersonville, O.

Donald Shepherd,

South Shore, Ky.

Howard Kaltenback

South Webster, O.

John Mishos, Hamilton, O.

David Van Tress

Springfield, O. 

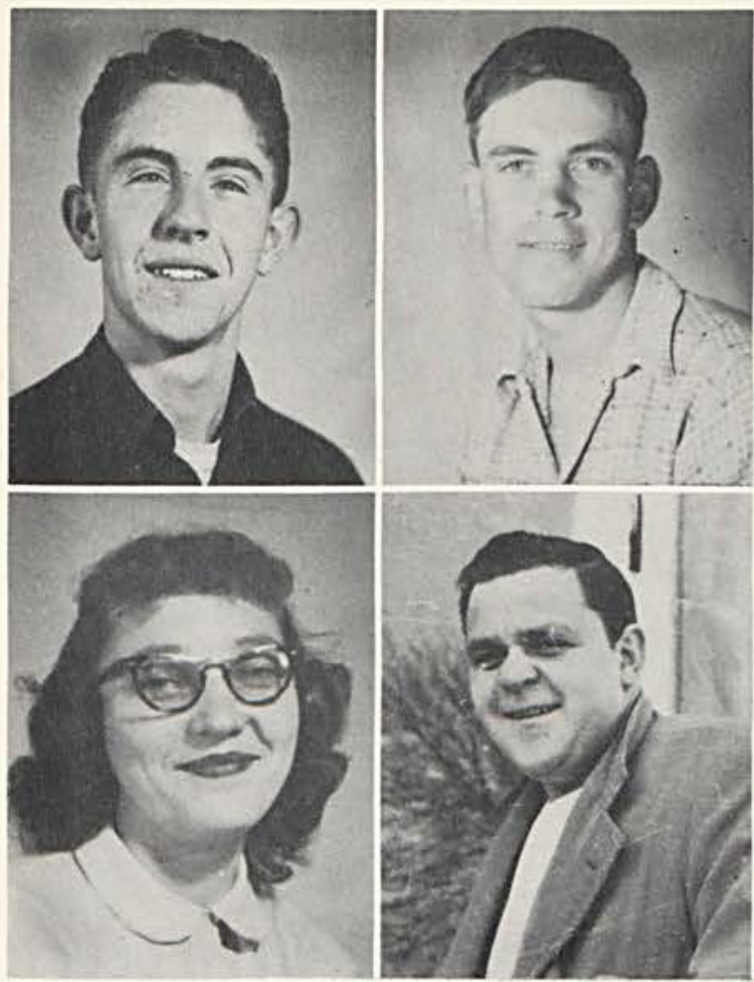

Max Rogers, Jamestown, O. William Fife, Cedarville, O. William Albright, Bradford, O. James Hunter

Yellow Springs, 0 . Nathan Burr, Jamestown, O.

Mary Arnett, Greenville, O. Hugh Abbott, Hamilton, 0 . Sue Caudill, Cleves, O.

Vernon Francis, Versailles, O. Thomas Schwartz, Houston, O.

John Skyles, Union, O.

Arthur Judy, Cedarville, O.

Byron Ames, New Burlington, 0.

Edward Waite, Fairborn, $\mathrm{O}$. Max Pickering,

New Burlington, $\mathrm{O}$.

Charles Burns, Portsmouth, O.

Darrell Coe, Portsmouth, O. Bob Ruth, Portsmouth, O. John Spichty, Springfield, O.
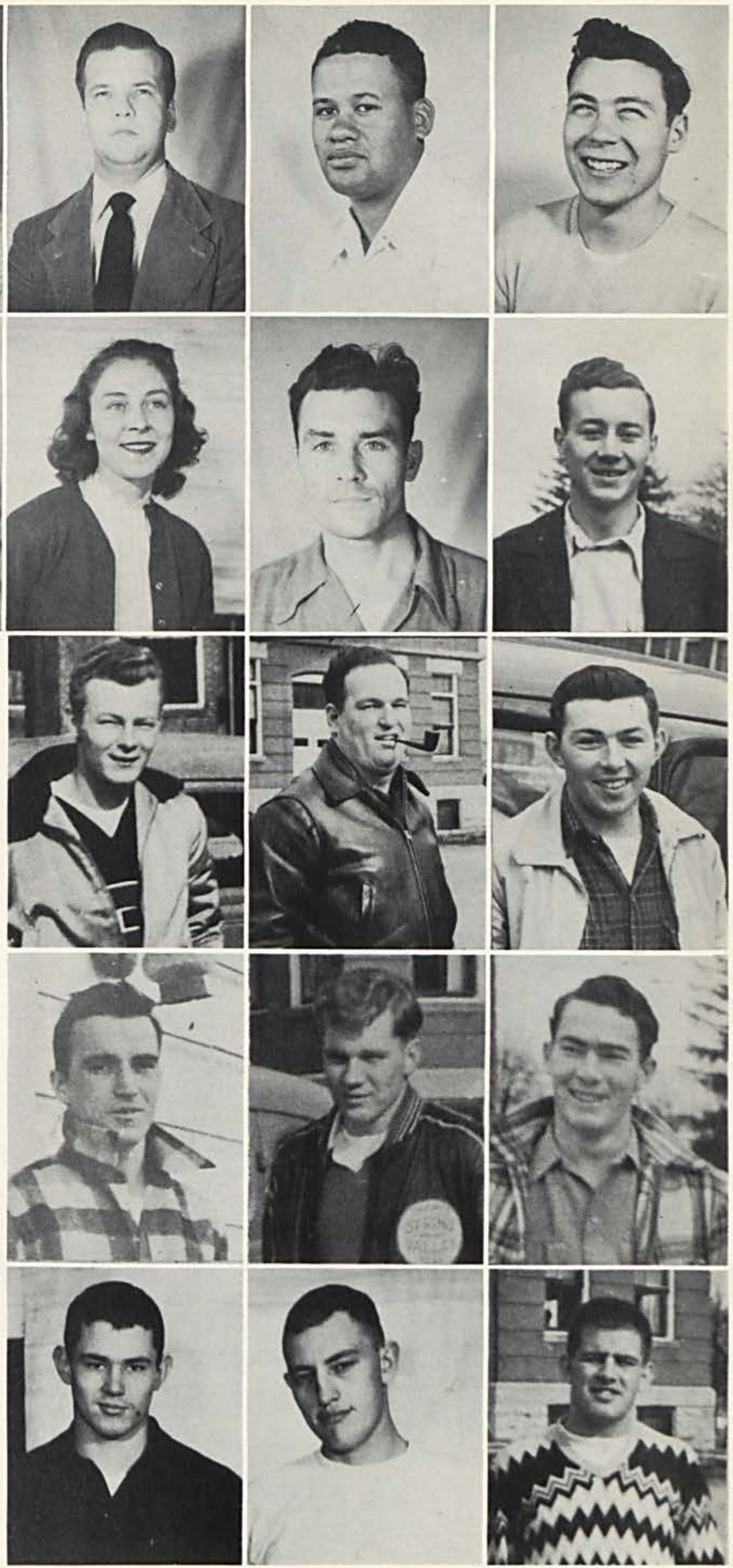

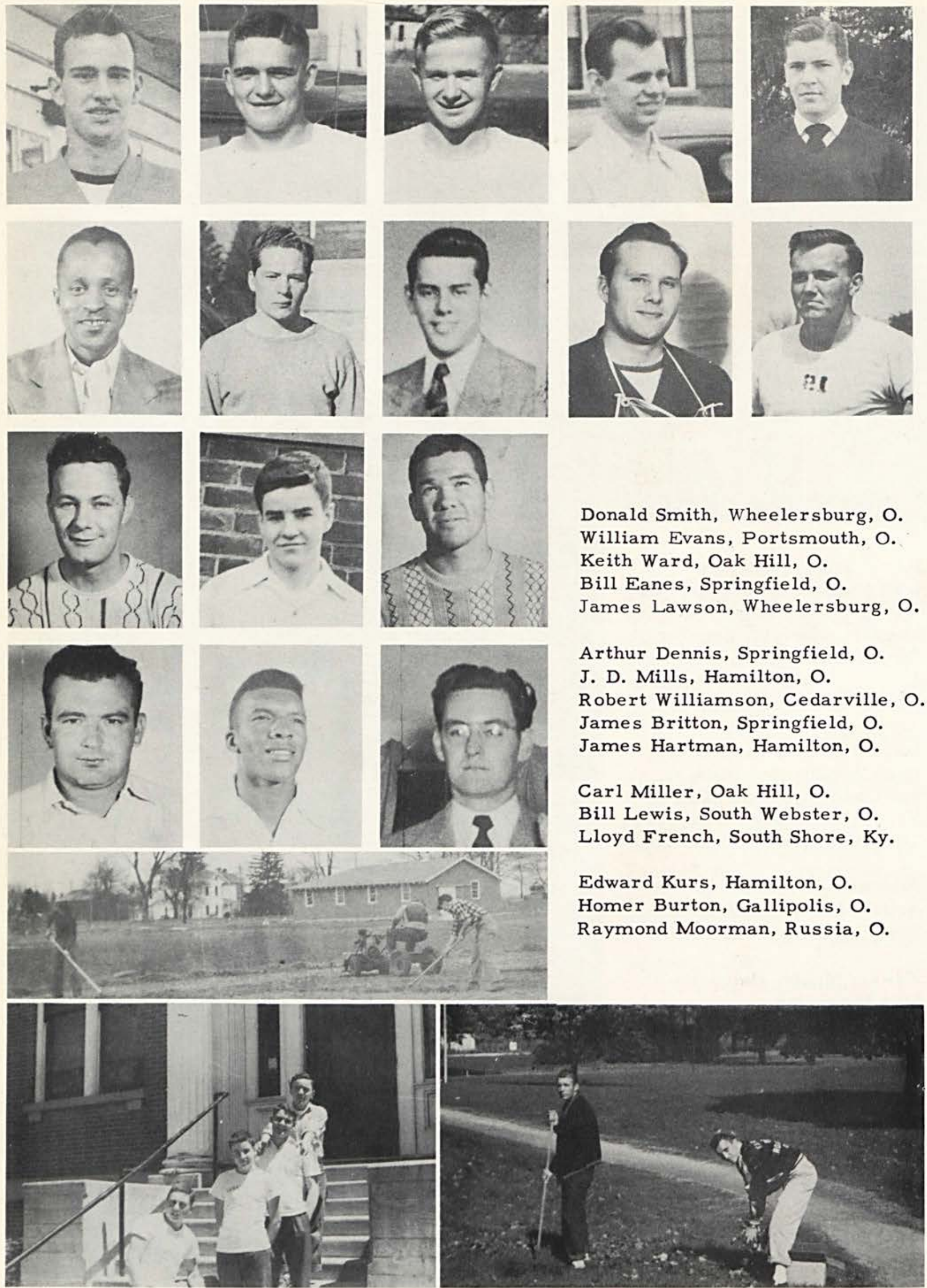
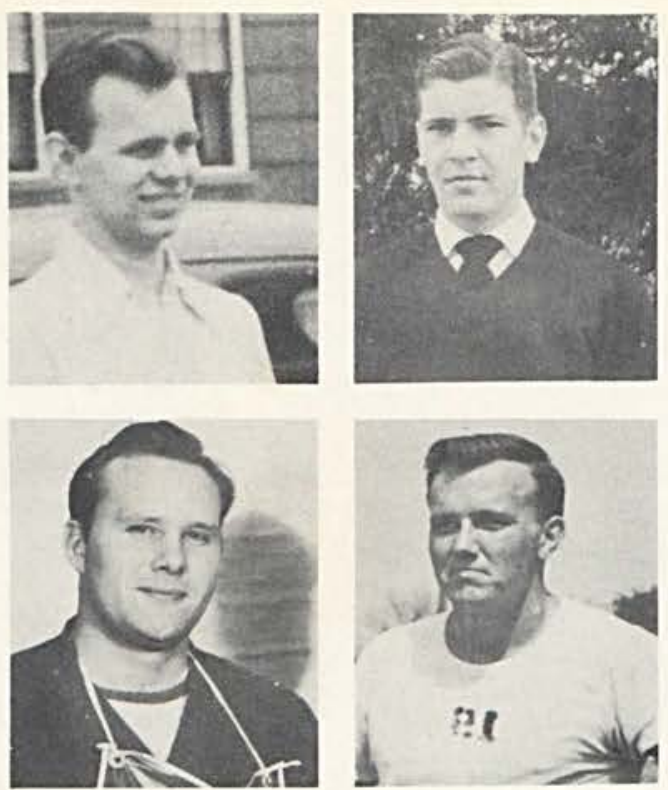

Donald Smith, Wheelersburg, O. William Evans, Portsmouth, $O$. Keith Ward, Oak Hill, O. Bill Eanes, Springfield, O. James Lawson, Wheelersburg, O.

Arthur Dennis, Springfield, O. J. D. Mills, Hamilton, O.

Robert Williamson, Cedarville, $O$. James Britton, Springfield, O. James Hartman, Hamilton, O.

Carl Miller, Oak Hill, O. Bill Lewis, South Webster, O. Lloyd French, South Shore, Ky.

Edward Kurs, Hamilton, O. Homer Burton, Gallipolis, O. Raymond Moorman, Russia, O. 


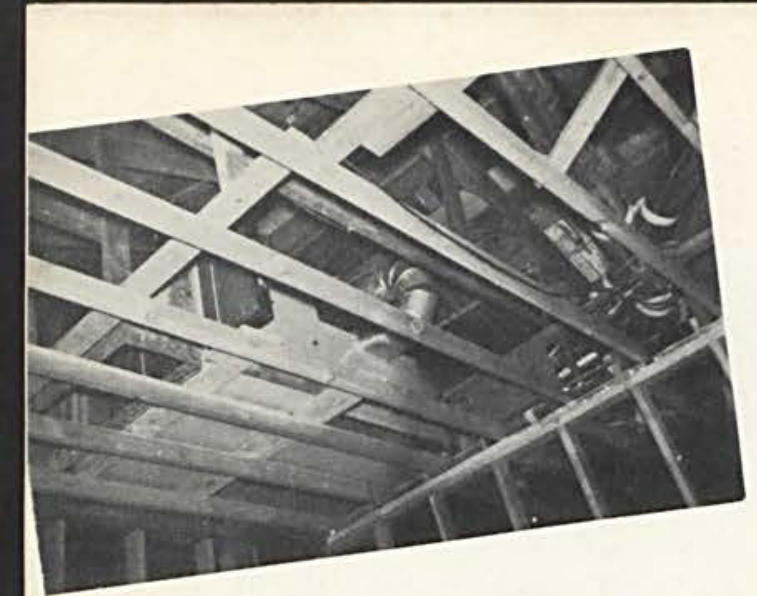

Value of floor space saved helps pay for the furnace.

"Above ceiling" installation of furnace in new science building.

Lennox Furnaces

Coal, Oil, and Gas

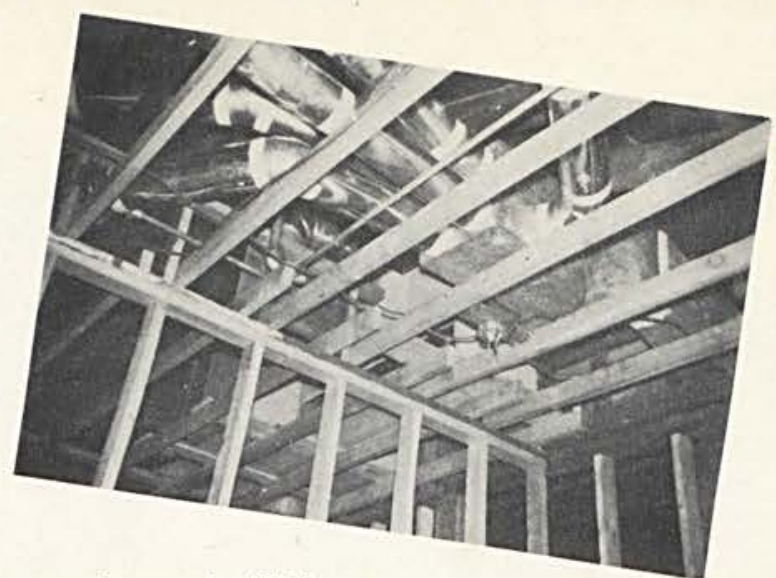

Coleman Floor Furnaces

Oil and Gas

\section{COLEMAN AUTOMATIC HOT WATER HEATERS}

Oil and Gas, Installed

C. C. Brewer

Phone 6-2251

Cedarville

Besides improving looks and cutting maintenance costs our properly installed siding and roofs extend the useful life of a building.

Before

After

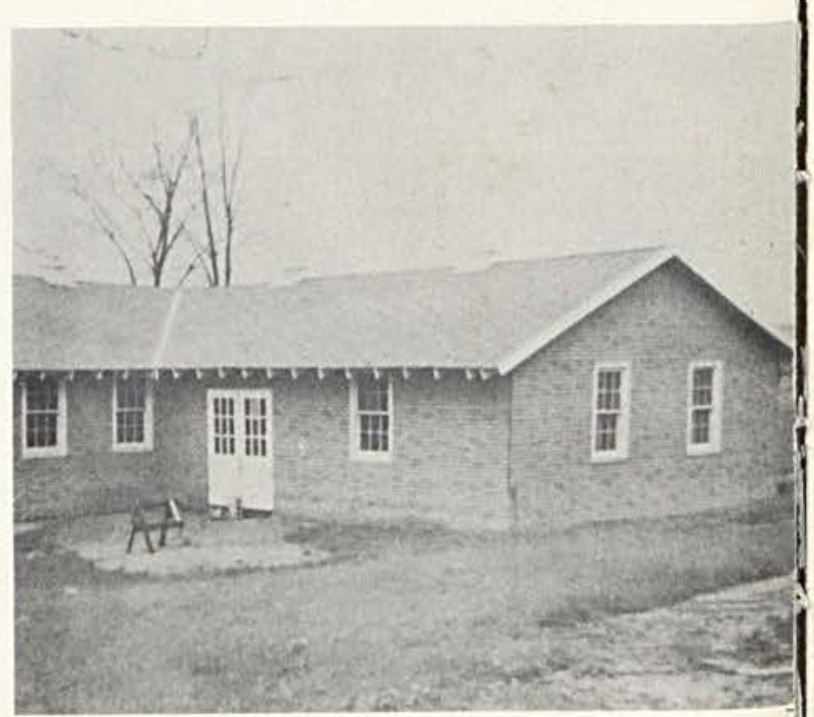

PATROMIZE OUR ADVERTISERS, THEY MAKE THIS BOOK POSSIBLE 


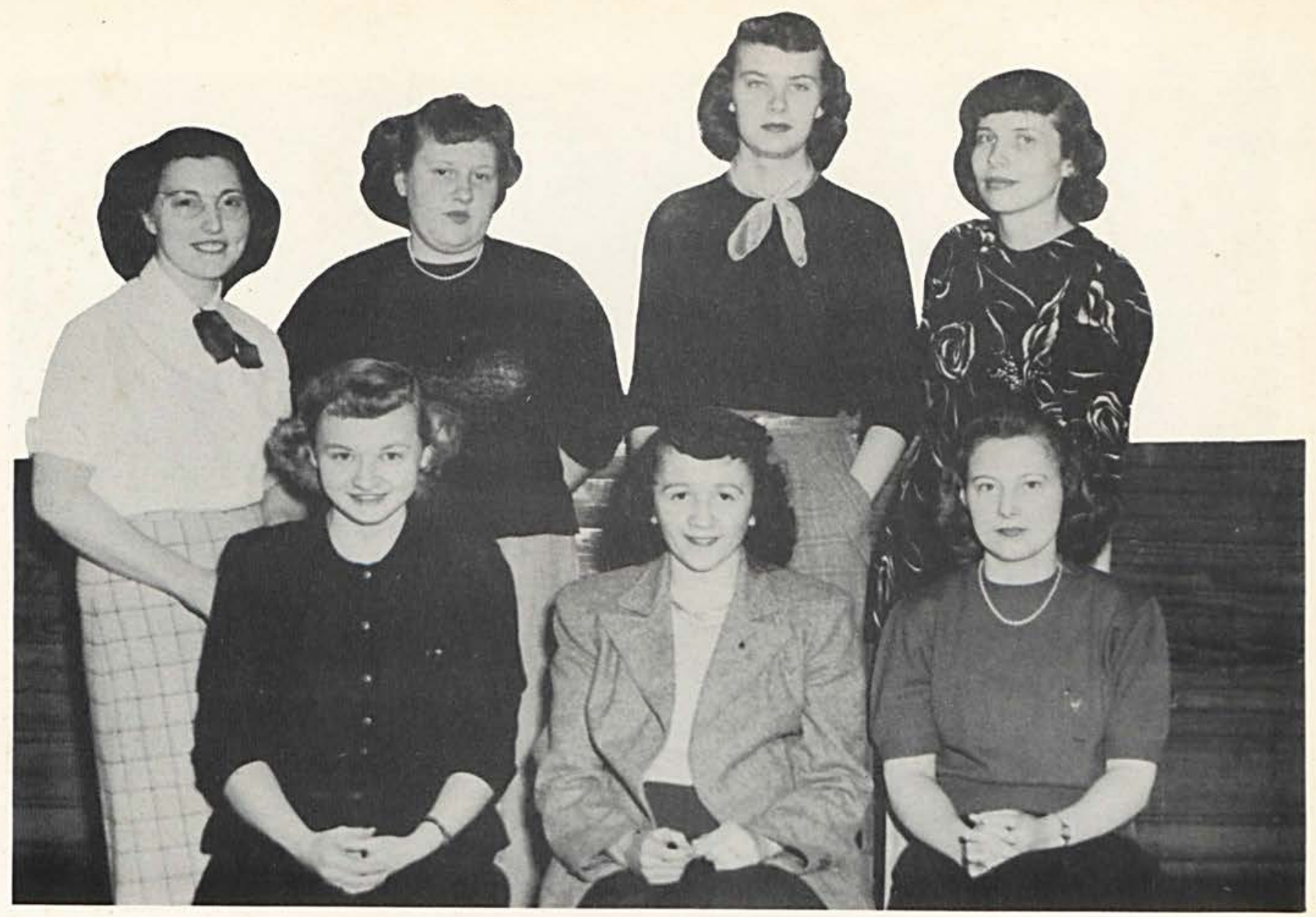

FIRST ROW: JOANNE SANDERSON, EdIE RUTAN, VIOLA THURMAN. SECOND ROW: MARTHA TANNEHILL, MARCELYN GIRNUS, MARY LOUISE STORMONT, PHYLLIS BRYANT.

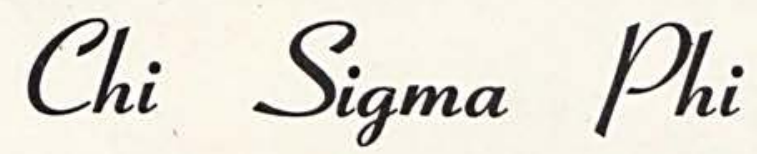

The Chi Sigma Phi is a local sorority which was organized in 1935. It has pledged new members every semester since that time. At the present time the sorority has ten members. It upholds high scholarship and moral standards and helps to promote fellowship among the women students.

This organization sponsors at least one social event during the year and several parties which are enjoyed by the members only.

\section{OFFICERS}

President . . . . . Eleanor Weismiller Vice president. . . . . . Joanne Sanderson Secretary . . . . . . . Phyllis Bryant Treasurer . . . . . . . Marie Fisher Reporter. . . . . . . Martha Tannehill Faculty advisor . . . . . . . Miss Rife

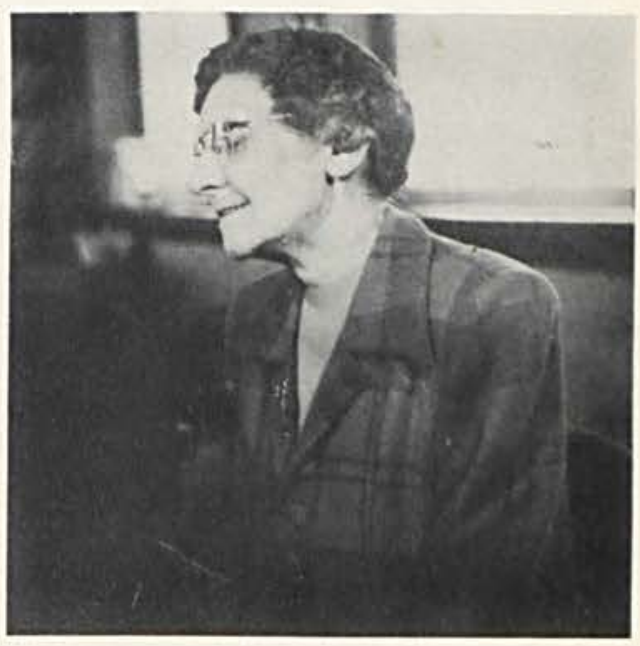

Miss Rife 


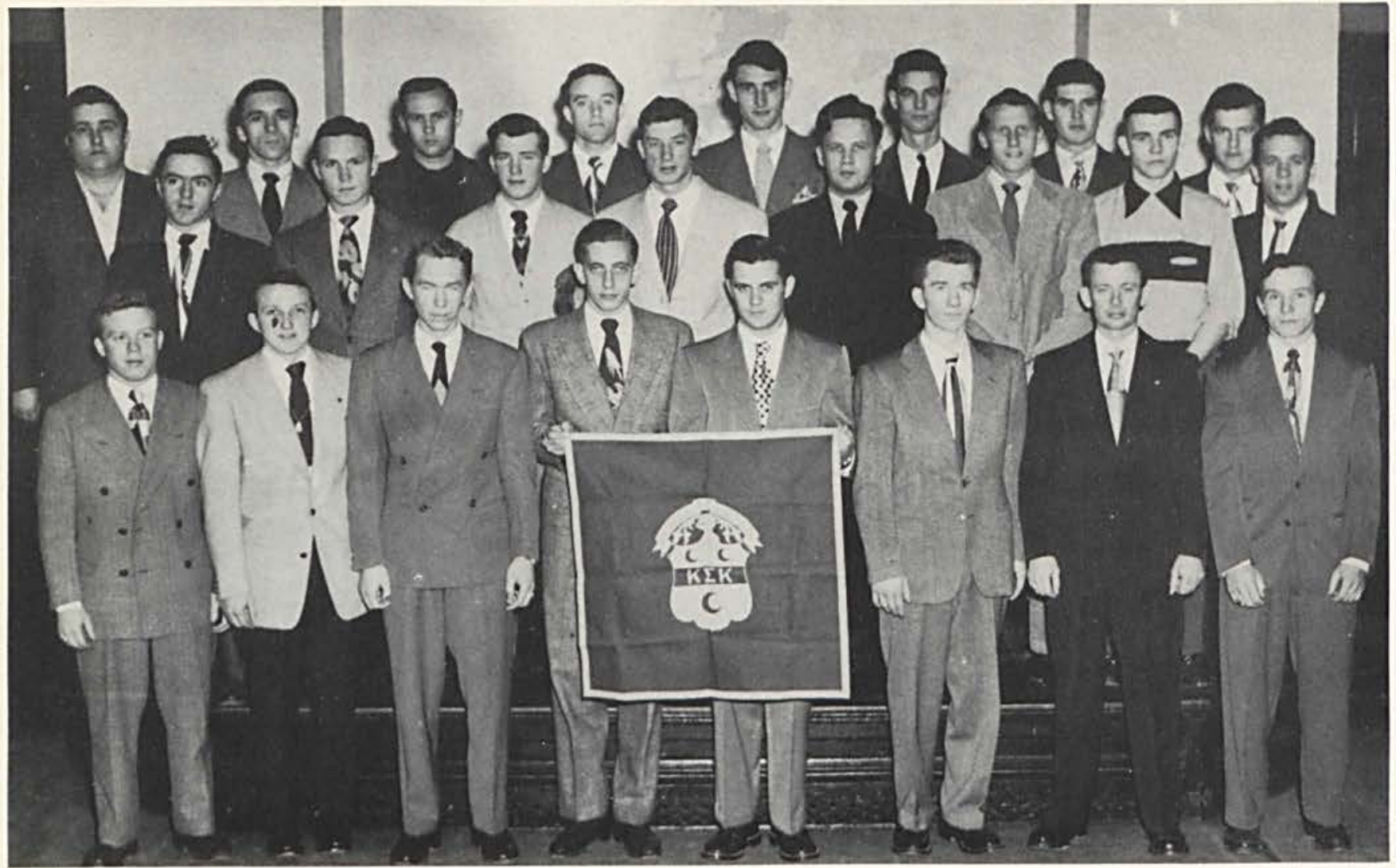

FIRST ROW: D. NOCK, D. SPItZer, J. Belville, P. Fiedler, B. Dunlap, T. Belville, B. OSMAN, F. BUTTS. SECOND ROW: J. LEWIS, B. CUNNINGHAM, J. SHAFFER, H. BEATTIE, J. STEWART, T. OSBORNe, D. CULTICE, P. DUNN. THIRD ROW: H. FISHER, J. DUNN, J. ROSS, G. CULtice, f. STEVENS, B. RADER, D. HARNER, B. MCNULtY.

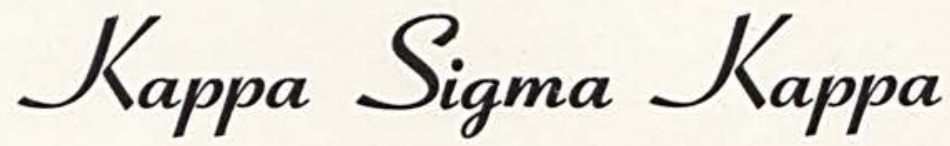

THE LOCAL CHAPTER OF KAPPA SIGMA KAPPA WAS CHARTERED ON MAY 22, 1948, AND NOW HAS COMPLETED TWO VERY SUCCESSFUL YEARS ON THE CAMPUS. IN THESE TWO YEARS IT HAS GROWN TO BE THE LARGEST FRATERNITY ON THE CAMPUS.

THE OFFICERS FOR THE PAST YEAR HAVE BEEN DONALD NOCK, PRESIDENT; BILL DUNLAP, VICE-PRESI DENT; JIM DUNN, SECRETARY; CARL WISEMAN, TREAS URER; JAMES LEWIS, SEARGENT-AT-ARMS; JIM SHAFFER, CORRESPONDING SECRETARY; AND PAUL FIEDLER, REPORTER .

AMONG ITS SUCCESSES HAS BEEN THE ANNUAL
CHRISTMAS FORMAL. THIS YEAR THE MUSIC WAS PROVIDED BY CURLY MILLER AND HIS ORCHESTRA. ANOTHER EVENT WHICH IS TURNING OUT TO BE AN ANNUAL AFFAIR IS THE EASTER EGG HUNT STAGED DURING THE WEEK PRECEDING EASTER FOR THE CHILDREN IN THE FIRST THREE GRADES OF THE PUBLIC SCHOOL.

THE FIRST SEMESTER PLEDGE BANQUET WAS ENJOYED By alL. IT WAS HELd at THE "BEe \& THISTLE" RESTAURANT AND ENTERTAINMENT WAS PROVIDED BY THE "DAFFY DUO."

EVEN NEW AND BETTER THINGS ARE BEING PLANNED FOR THIS COMING YEAR, SO THIS GROUP IS DESTINED TO HAVE ANOTHER VERY SUCCESSFUL YEAR.

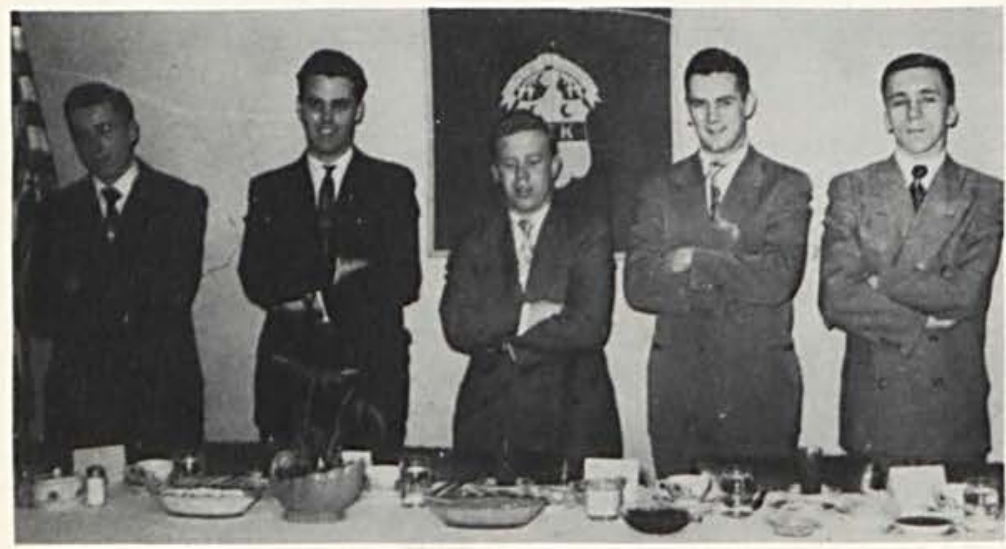

Carl Wiseman

Prof. Ramsey

Donald Nock

Bill Dunlap

James Dunn 


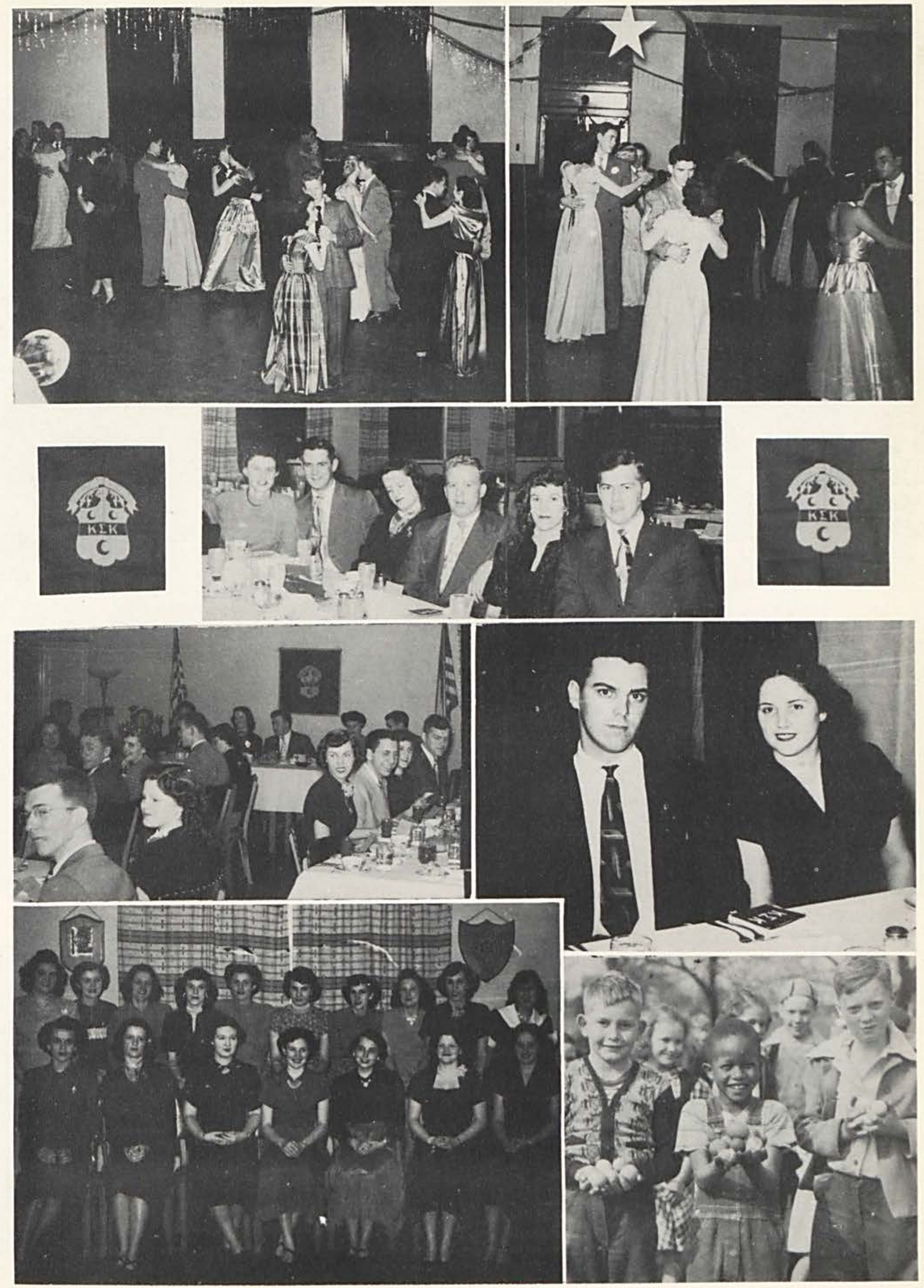




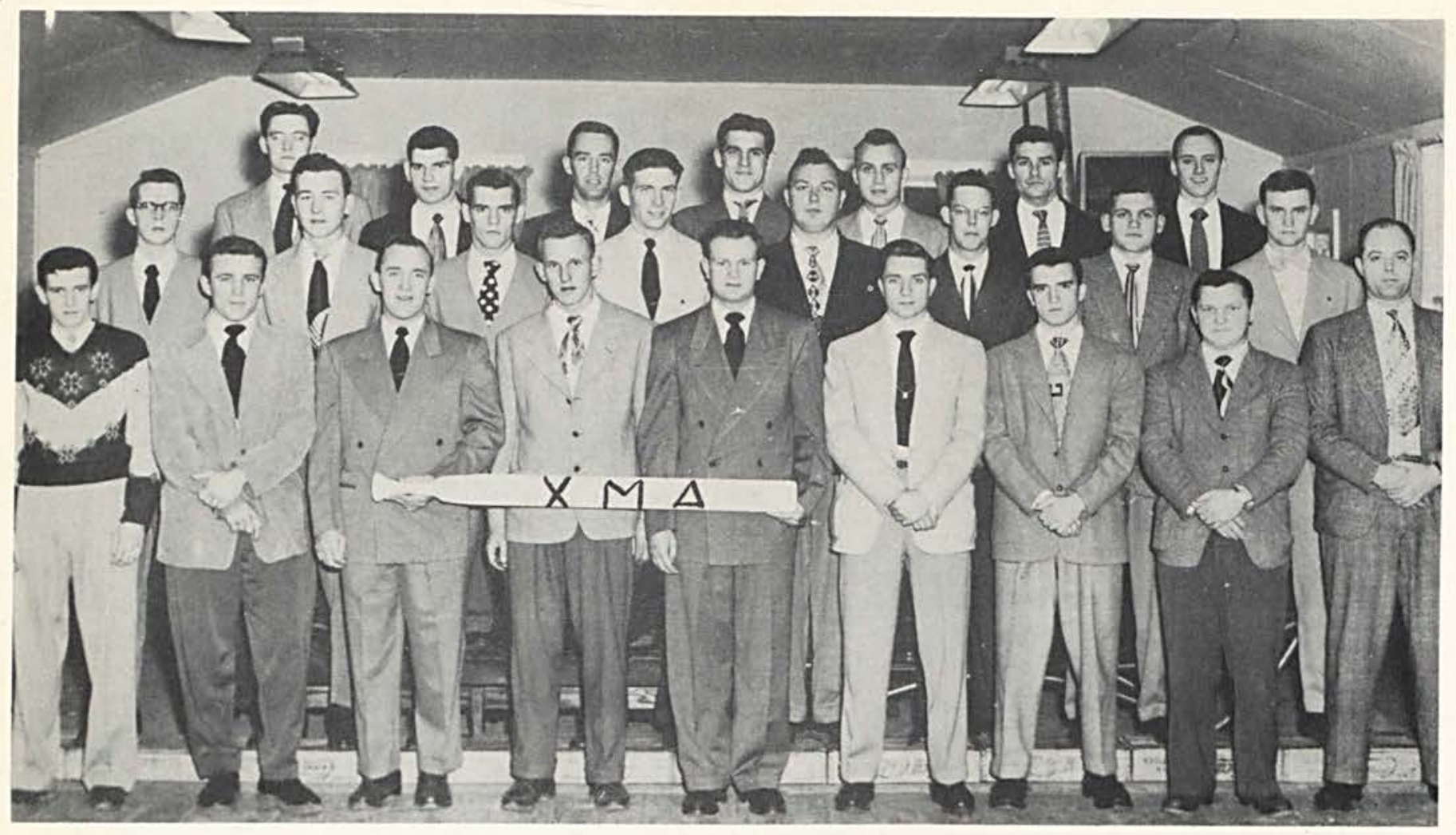

IST ROW: WRIGHT, CARPENTER, SNOWDEN, STAGgS, HAMMOND, WISECUP, WAITE, KLONTZ, HOWARD WISE-FACULTY ADVISOR. 2ND ROW: PURDOM, SWARTZ, STANLEY, TOWNSLEY, BRADBURY, ULSH, WILBURn, RADAR. 3RD ROW: MOORMAN, KING, HufFMan, PETERs, PICKENS, FRANCIS, THOMPSON. NOT PRESENT: WAGNER, LONG, GENTILE, FRENCH.

The Chi Mu Delta Fraternity has completed another active and successful year at Cedarville College. This organization which was founded in 1941 has distinguished itself socially and scholastically during the past school year.

A Hallowe'en Carnival and a Spring Formal dance which completed the Cedar Day activities were the most important social events sponsored by this group. Through the year the Chi Mu Delta worked with other organizations to improve relationships and conditions at this college.

The fraternity has kept in contact with alumni members and welcomed them back to special meetings and various college events.

Kenneth Huffman has served as president of the Chi Mu Delta during 1949-50. Roger Ulsh was vice-president; Kenneth Wilburn, secretary; John Townsley, treasurer; Dave King, sergeant-at-arms.

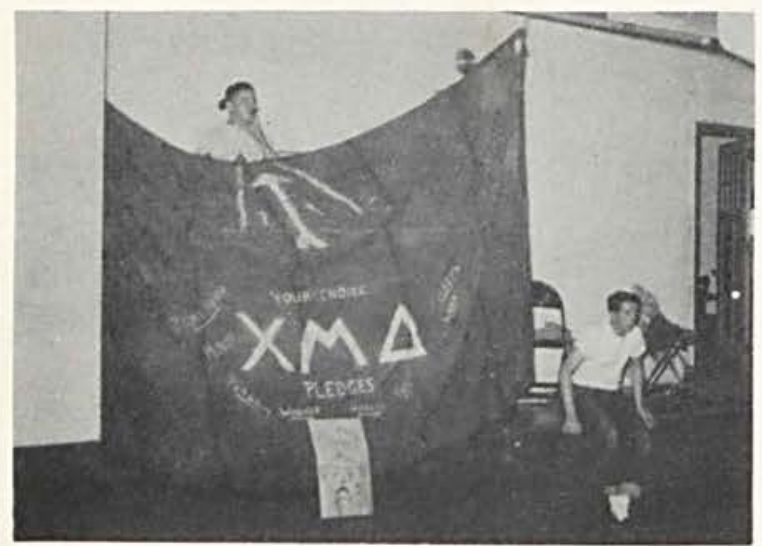

\section{Chi Mu Delta}



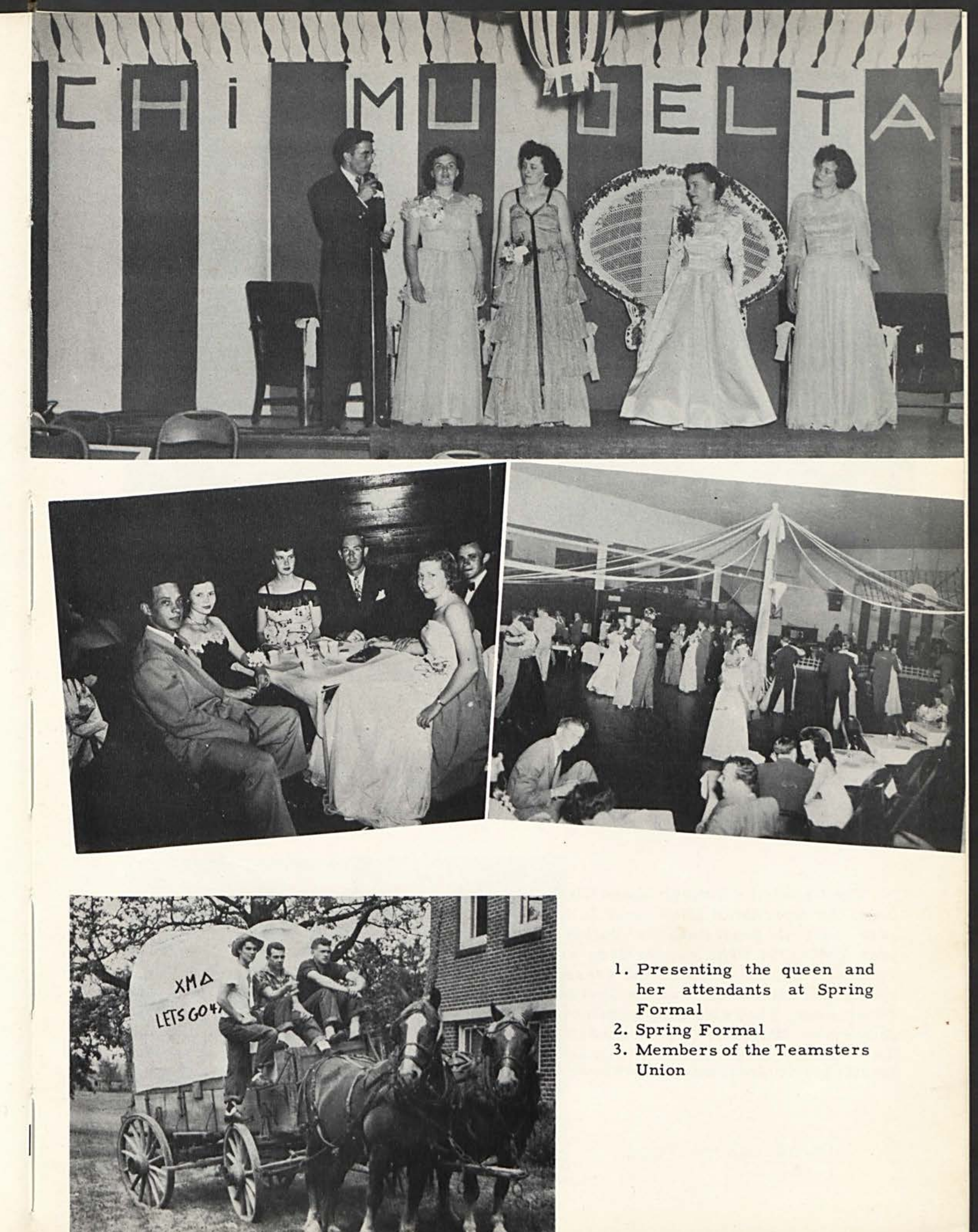

1. Presenting the queen and her attendants at Spring Formal

2. Spring Formal

3. Members of the Teamsters Union 


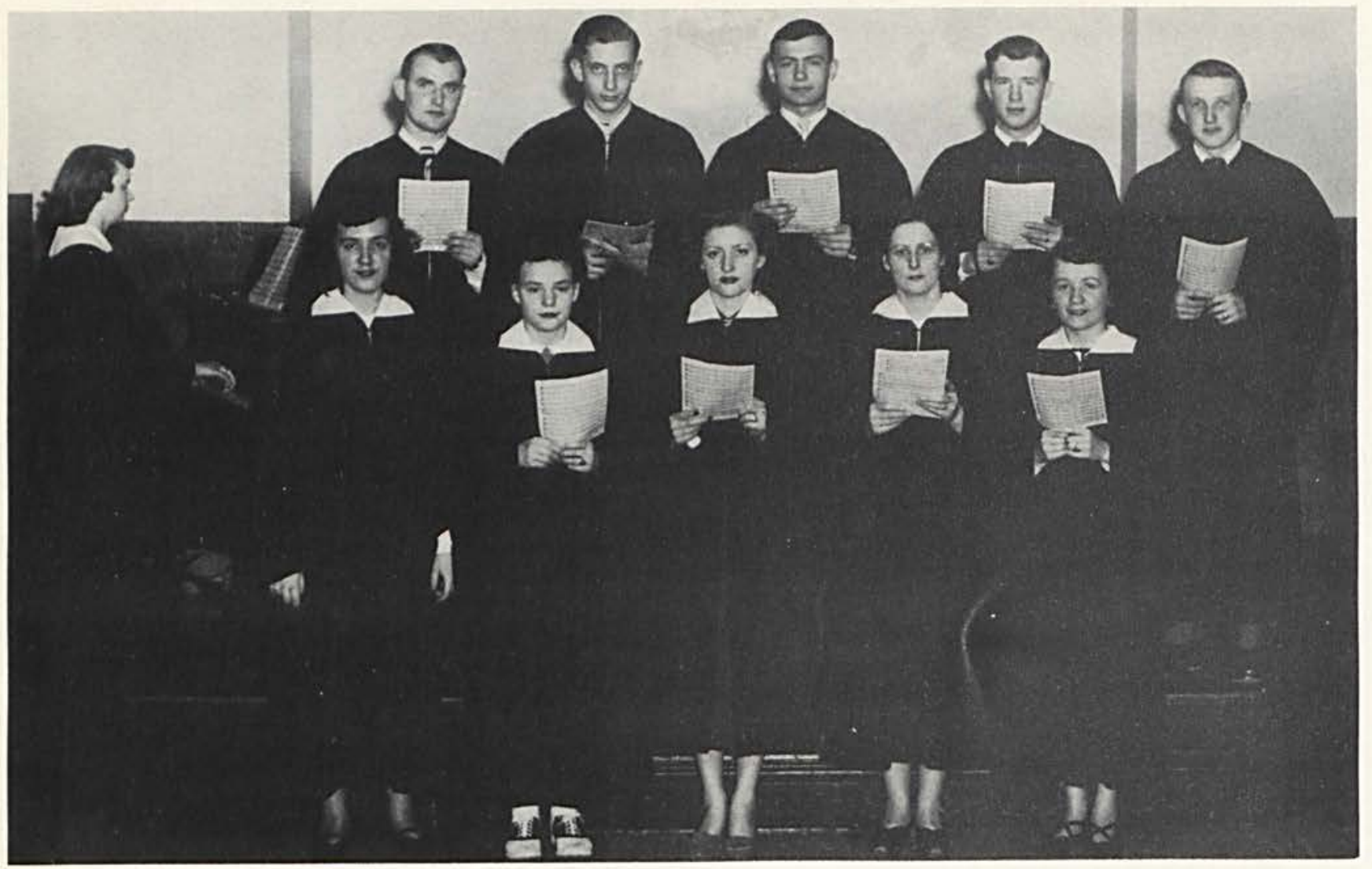

FIRST ROW: MISS NANCY BOST, MUSIC DIRECTOR, NAOMI CONNER, NAOMA NEWMAN, MRS. LOUISE HARNER, ELOISE E. RUTAN. SECOND ROW: MARY LOUISE STORMONT, ACCOMPANIST, THEODORE SUTTON, JAMES SCHAFER, AND DAVID SPITZER. VIOLA THURMAN WAS NOT PRESENT WHEN THE PICTURE WAS TAKEN.

\section{Mixed Chorus}

The Cedarville College Mixed Chorus, under the direction of Miss Nancy L. Bost, gave several performances during the year 1949-1950. The chorus sang at the Thanksgiving Convocation and presented special Christmas music at the Christmas Convocation. They also sang at Salem and Jamestown, Ohio, and provided music for the Women's Bible Reading Contest. A special music program was presented at the Easter Convocation.

The following participated actively in the music program: sopranos-Mrs. Louise Harner, Naomi Conner, Viola Thurman; altos-Edie Rutan, Naoma Newman, Mrs. Don Swank; tenors-Robert Miller, Roger Charles, Paul Fiedler; basses-Ted Sutton, Dave Spitzer, and James Schafer, accompanist-Mary Louise Stormont. 


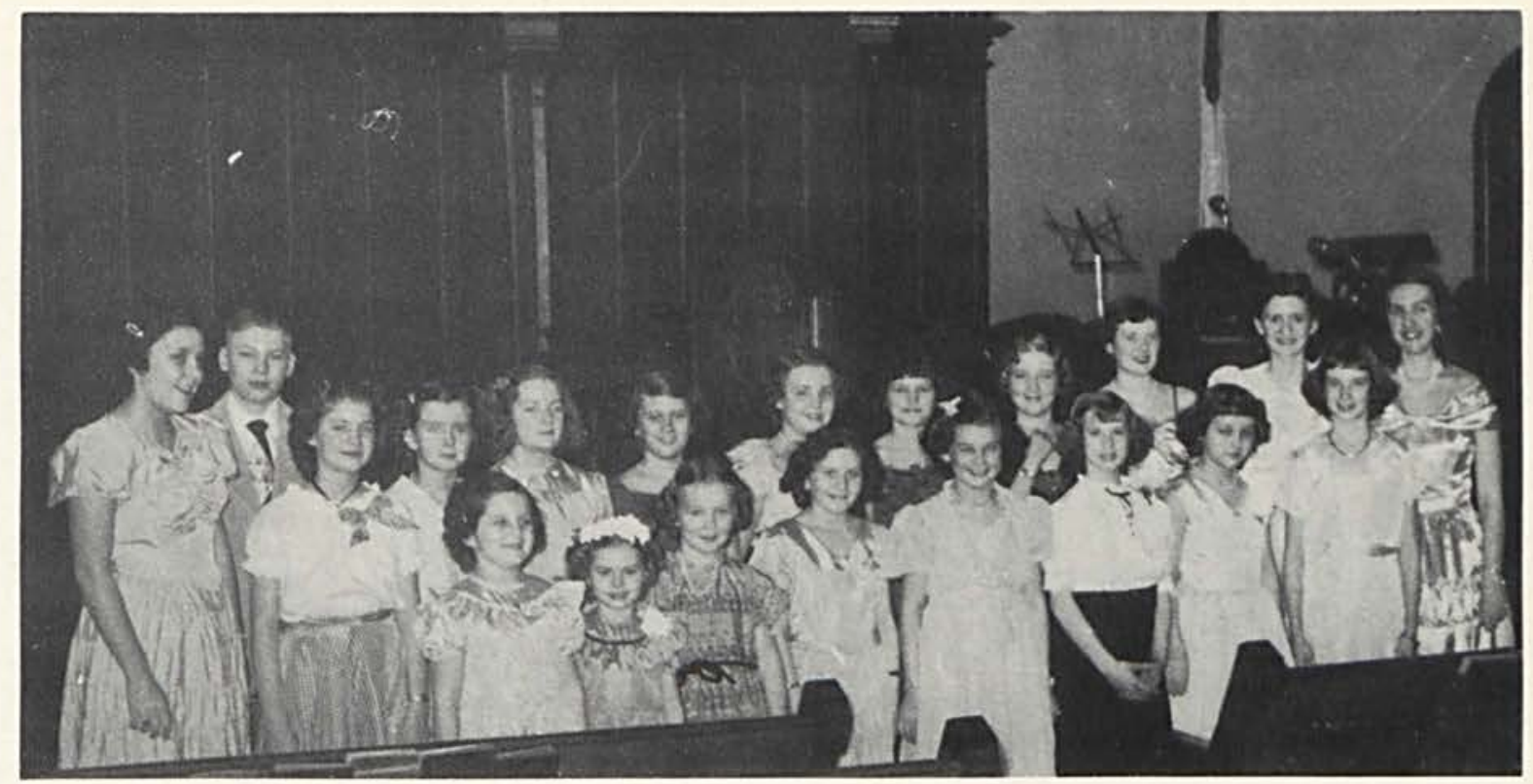

STUDENTS IN FORMAL RECITAL

FIRST ROW: DIANE REITER, CONNIE ENGLE, MARY LEE CUMMINGS, JANET MCMILLAN, CAROLYN THORDSEN, JANE E. DOBBINS, DOLLY RITENOUR, LORETTA FERRELLS, DORIS REYNOLDS. SECOND ROW: SHIRLEY POWERS, TED REITER, JOY EVANS, PEGGY BURR, LINDA GORDON, JANE MCMILLAN, JANICE WILBURN, LYNN CUMMINGS, KAY LEFFEL, ANNE HUFFMAN, AND MISS NANCY BOST, MUSIC DIRECTOR. RONALD HARNER AND JOAN NASH WERE NOT PRESENT WHEN THE PICTURE WAS TAKEN.

The "Yellow Jacket Four" quartet has presented several public programs this year. They gave a barbershop number, "Strolling Through The Park," in costume when they participated in the four college variety show at Xenia. They have sung at chapel programs, various churches, and gave a program at Cedarville High School.

They are: first tenor, Robert Miller from Bellefontaine, Ohio; second tenor, Paul Fiedler from Minerva, Ohio; baritone, Ted Sutton from Weirton, W. Va.; and bass, David Spitzer from Tipp City.

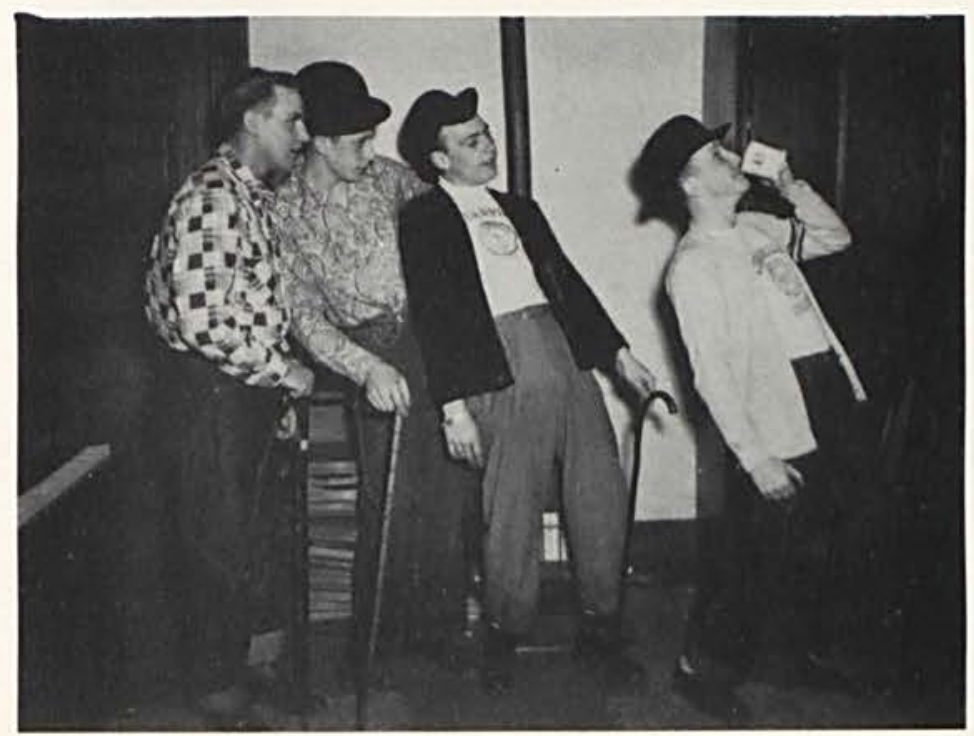




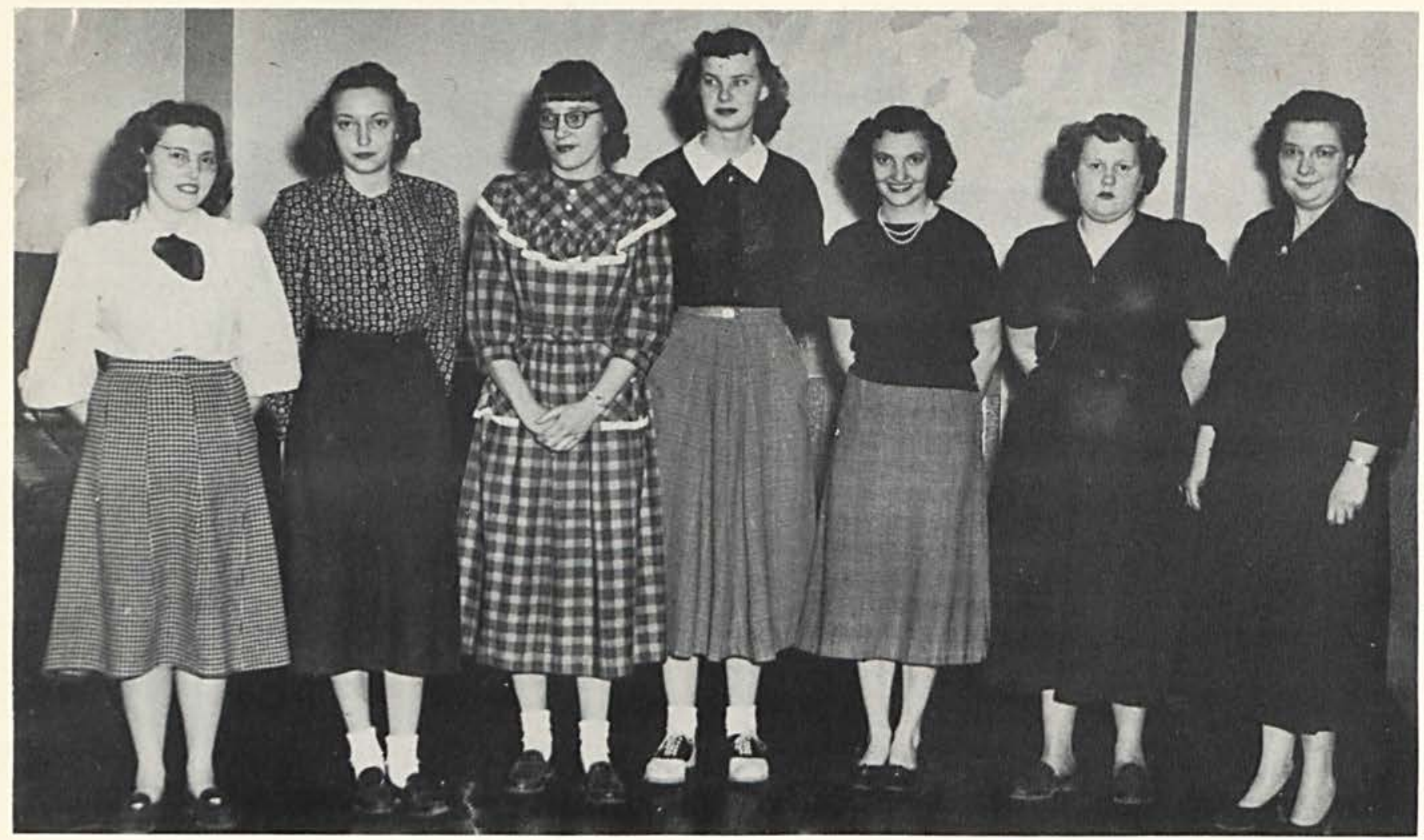

Tannehill, French, Arnett, Stormont, Powell, Girnus, Mrs. Carlsen, Faculty Advisor.

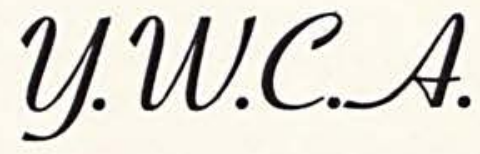

The Young Women's Christian Association endeavors to realize a full and creative life through a growing knowledge of God. Its members try to reach this aim through devotional meetings and through various charitable and social activities.

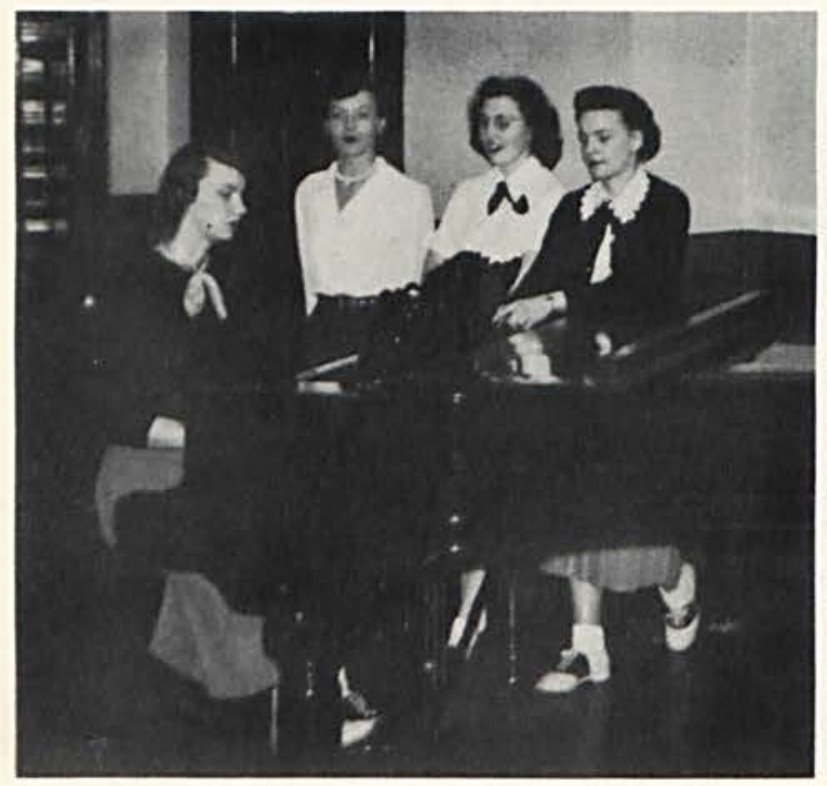

The Y.W.C.A. regularly holds a tea in the fall to aid new students in getting acquainted.

The Y.W.C.A. joins with the Y.M.C.A. in sponsoring the World Student Service Fund drive to aid needy students in the war torn countries of the world.

\section{Y.W.C.A. OFFICERS}

President . . .Mary Louise Stormont V. President. . . . Phyllis Bryant Secretary . . . . Joan Sanderson Treasurer . . . . . Marie Fisher Advisor. . . . . Mrs. Carlsen Devotional Chairman. .Martha Tannehill 


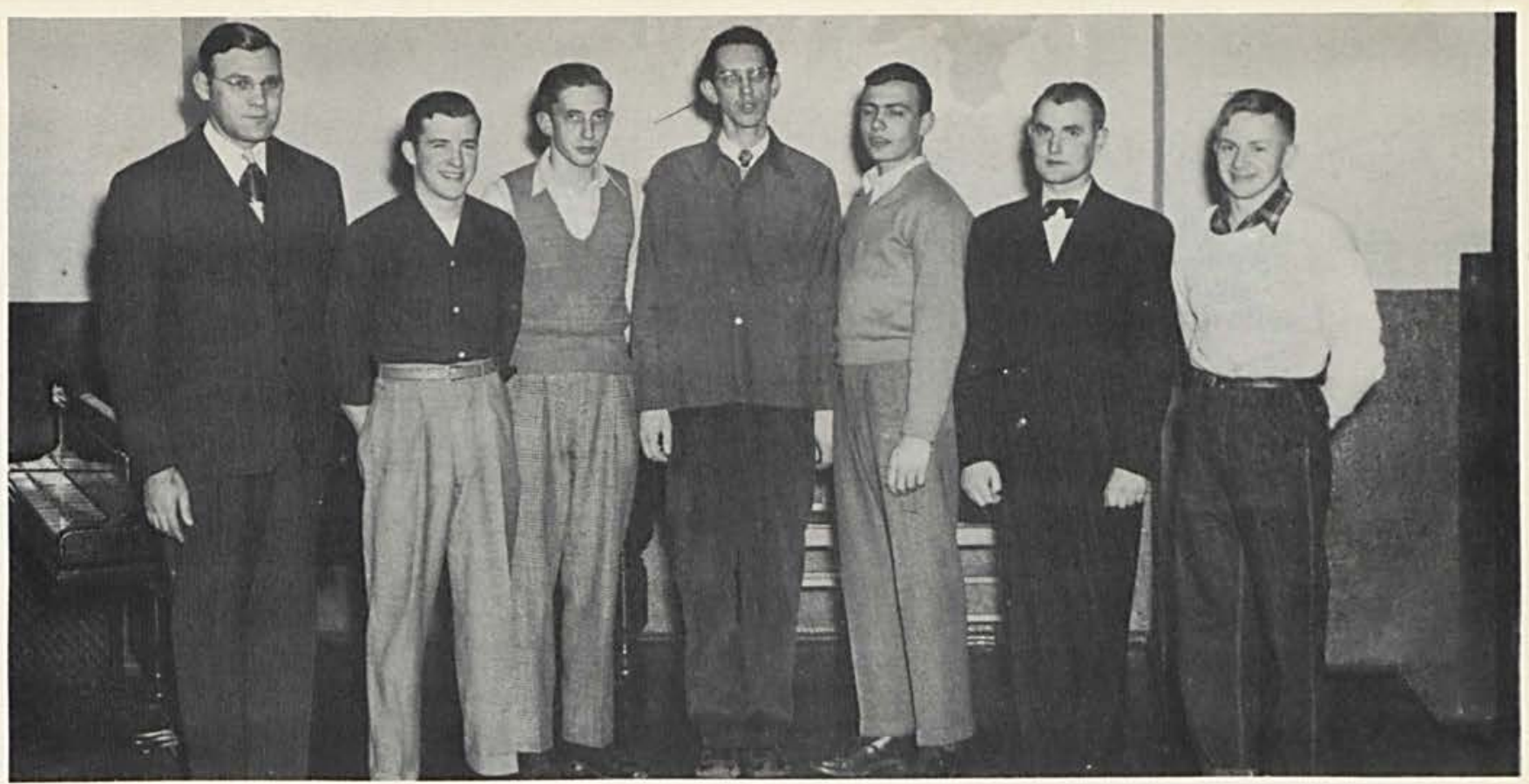

Mr. Carlsen, Jim Shaffer, Paul Fiedler, Meyers Bost, Ted Sutton, Bob Miller, Keith Ward.

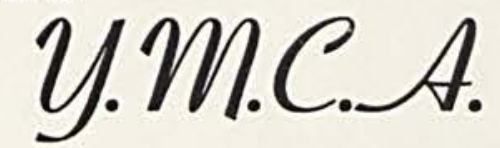

SEEKERS OF THE TRUTH

The Young Men's Christian Association strives to strengthen and nourish Christian character in the men on the campus. Its members seek to cultivate the physical, the mental and the spiritual sides of life.

Devotional and business meetings are held alternate Thursday evenings in the chapel with competent student leadership.

The Y.M.C.A. joins the Y.W.C.A. to

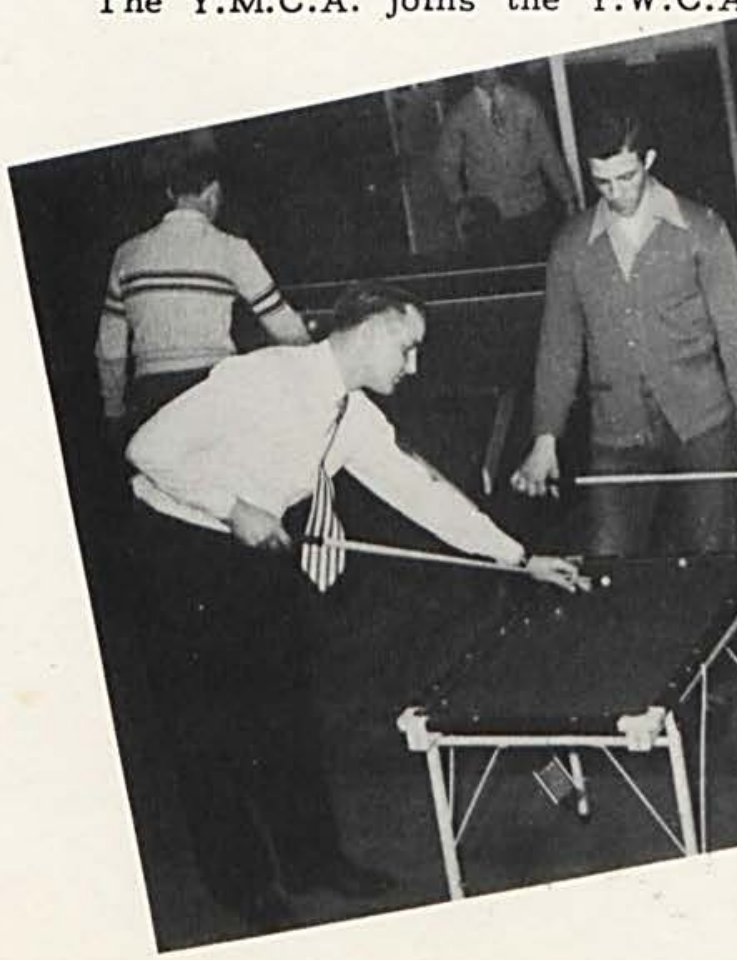

provide entertainment for students who remain on the campus over weekends. "Game Night" is a regular Firday evening feature held in the Recreation Hall.

The officers are: president, Hugh $\mathrm{Ab}-$ bott; vice president, David Van Tress; secretary-treasurer, Ted Sutton; devotional chairman, Keith Ward; advisor, Mr. Carlsen.

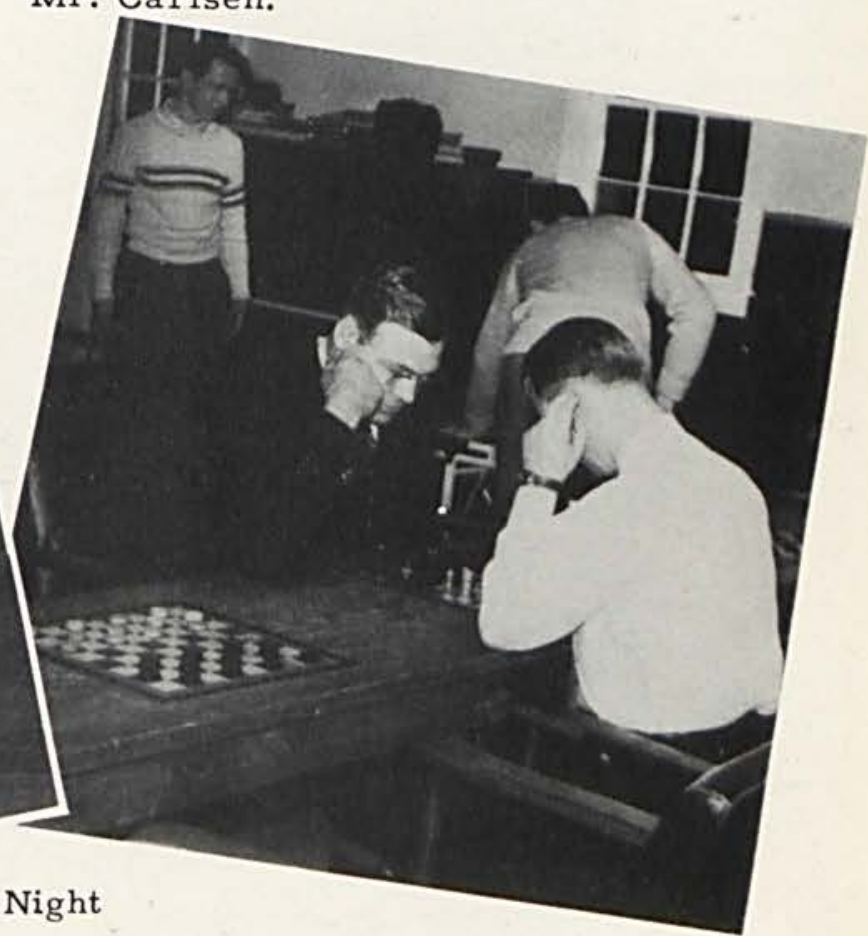




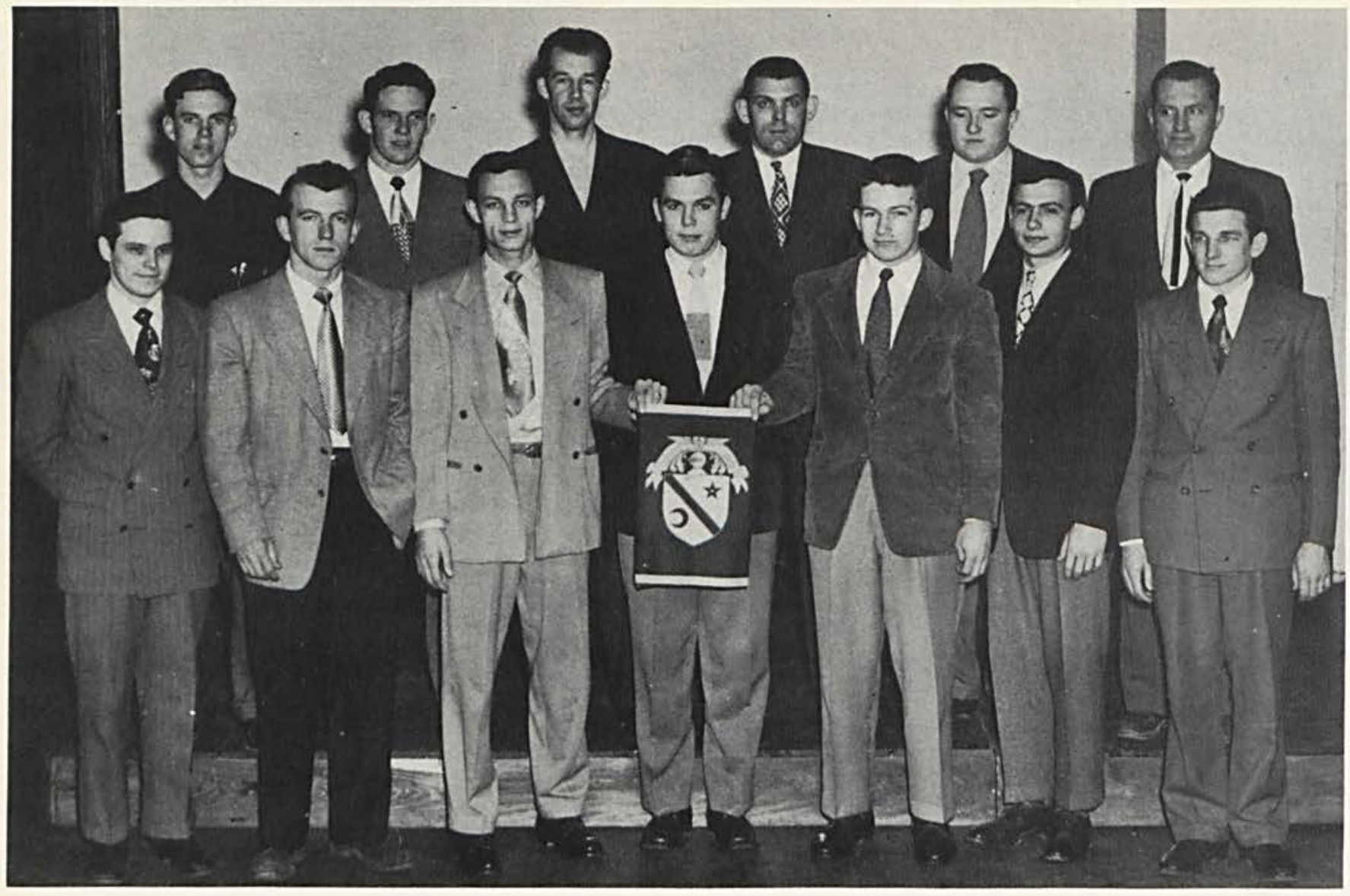

IST ROW: G. WATt, M. WEIMER, G. WILlLIAMS, D. SHEPHARD, A. JUSTICE, T. SUTtON, D. MARTIN. 2ND ROW: B. FIFE, W. EVANS, R. GLEnN, L. MCCARTY, J. Bauman, Prof. M. BEatTiE.

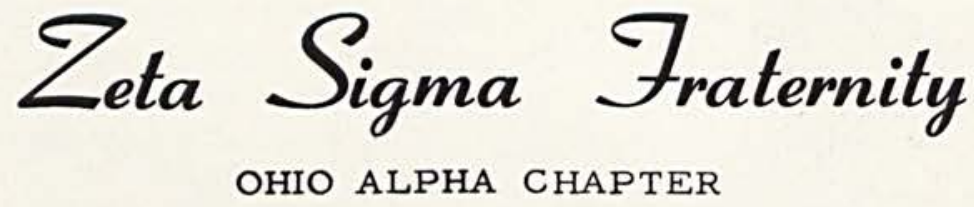

Zeta Sigma Fraternity was organized Cedarville College, January 27, 1950. in 1934. The National headquarters is located at Fairmont, West Virginia. To date it has 28 chapters in the United States. The Ohio Alpha Chapter was installed at

The officers are: President Gordon Williams, Vice President William Fife, Secretary-Treasurer, Archie Justus.

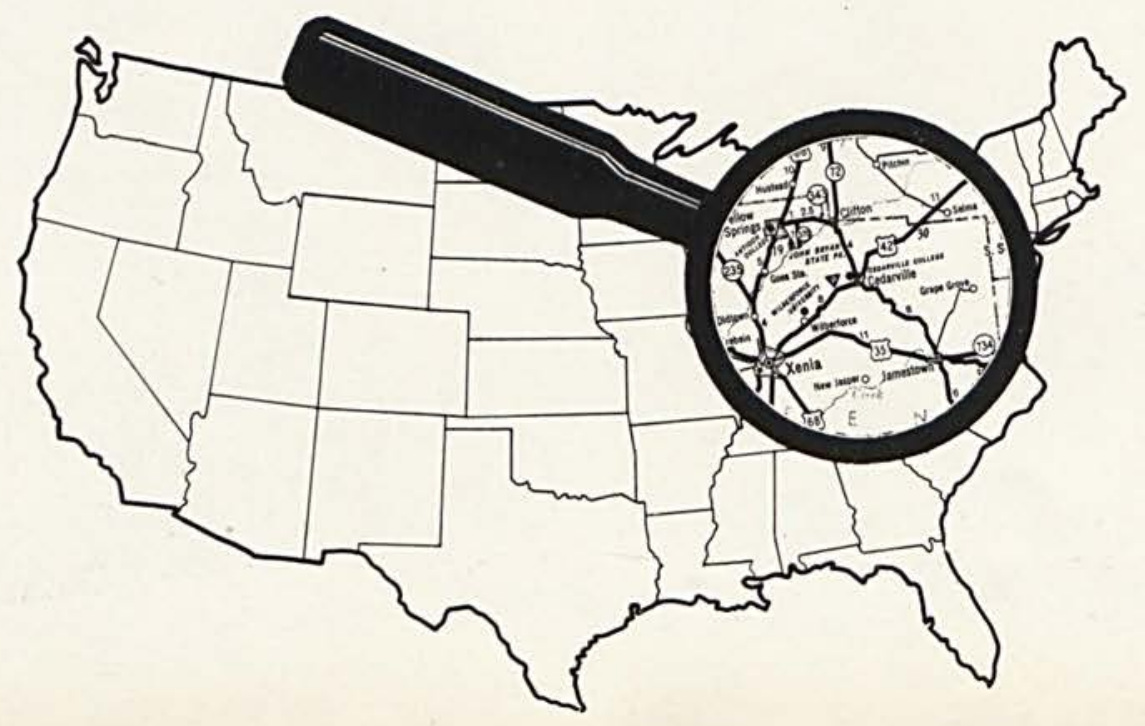




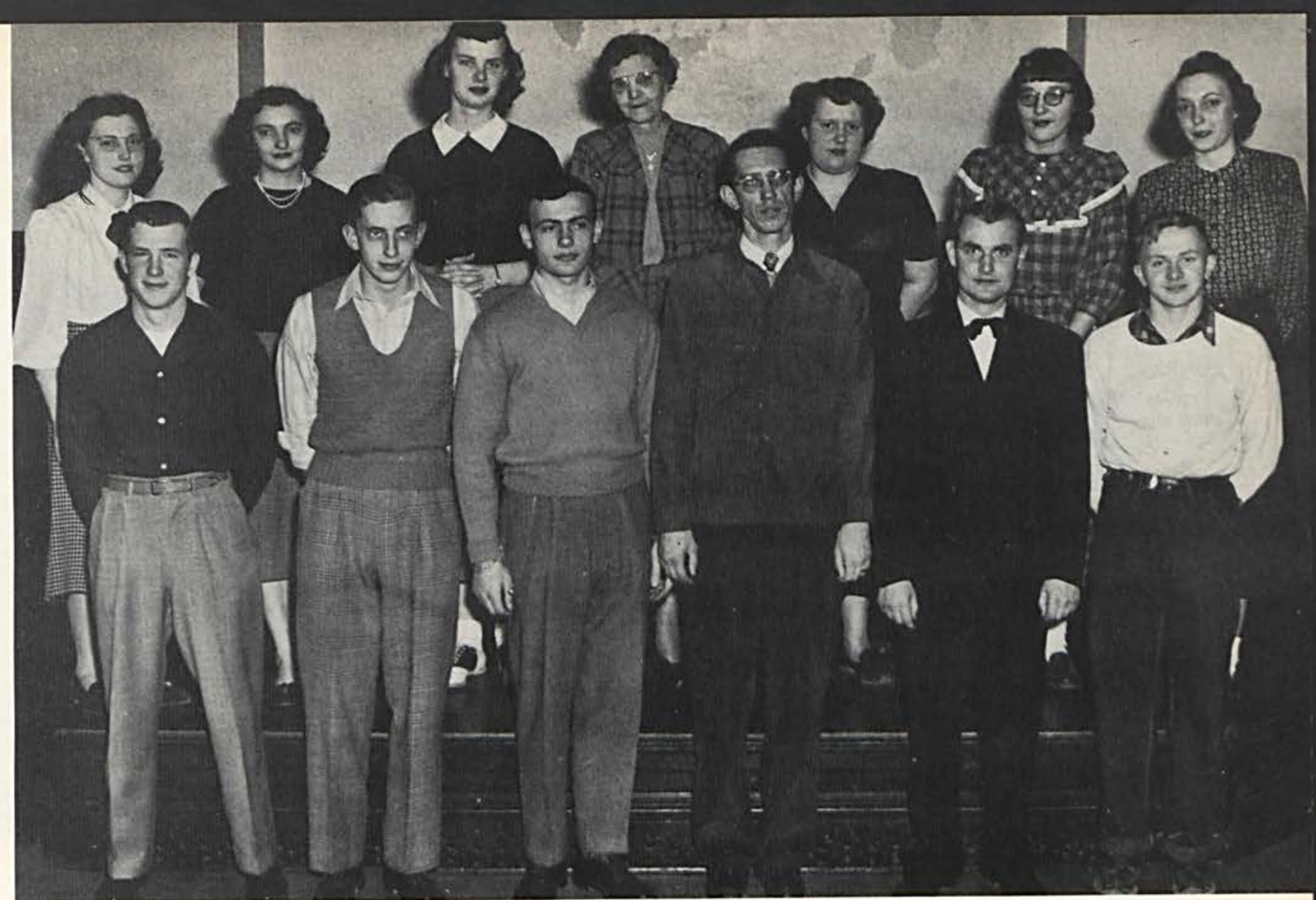

FIRST ROW: JIM SCHAFER, PAUL FIEDLER, TED SUTTON, MYERS BOST, ROBERT MILLER, KEITH WARD. SECOND ROW: MARTHA TANNEHILL, GERRY POWELL, MARY LOUISE STORMONT, MISS RIFE, MARCELYN GIRNUS, MARY ARNETT, MARY FRENCH.

\section{Caravaners}

THE CEDARVILLE COLLEge CARAVAN IS A VERY DEVOTED AND ENTHUSIASTIC ORGANIZATION. ANY STUDENT IS WELCOME TO JOIN. THERE IS A MEMBERSHIP OF APPROXIMATELY TWENTY.

RELIGIOUS PROGRAMS HAVE BEEN GIVEN AT VARIOUS SCHOOLS AND CHURCHES THROUGHOUT THE SURROUNDING AREA. EVERY MEMBER IS PRIVILEGED TO TAKE PART IN THESE PROGRAMS USING THEIR TALENTS FOR THE
GLORY OF GOD. A BANQUET IS HELD AT THE CLOSING OF EACH SCHOOL YEAR FOR ALL MEMBERS.

THE OFFICERS ARE: PRESIDENT, GEORGE WATT; VICE-PRESIDENT, PHYLLIS BRYANT; SECRETARY, MARIE FISHER; TREASURER, CARL WISEMAN; PROgRAM CHAIRMAN, MARY LOUISE STORMONT; FACULTY ADVISOR, MISS RIFE.

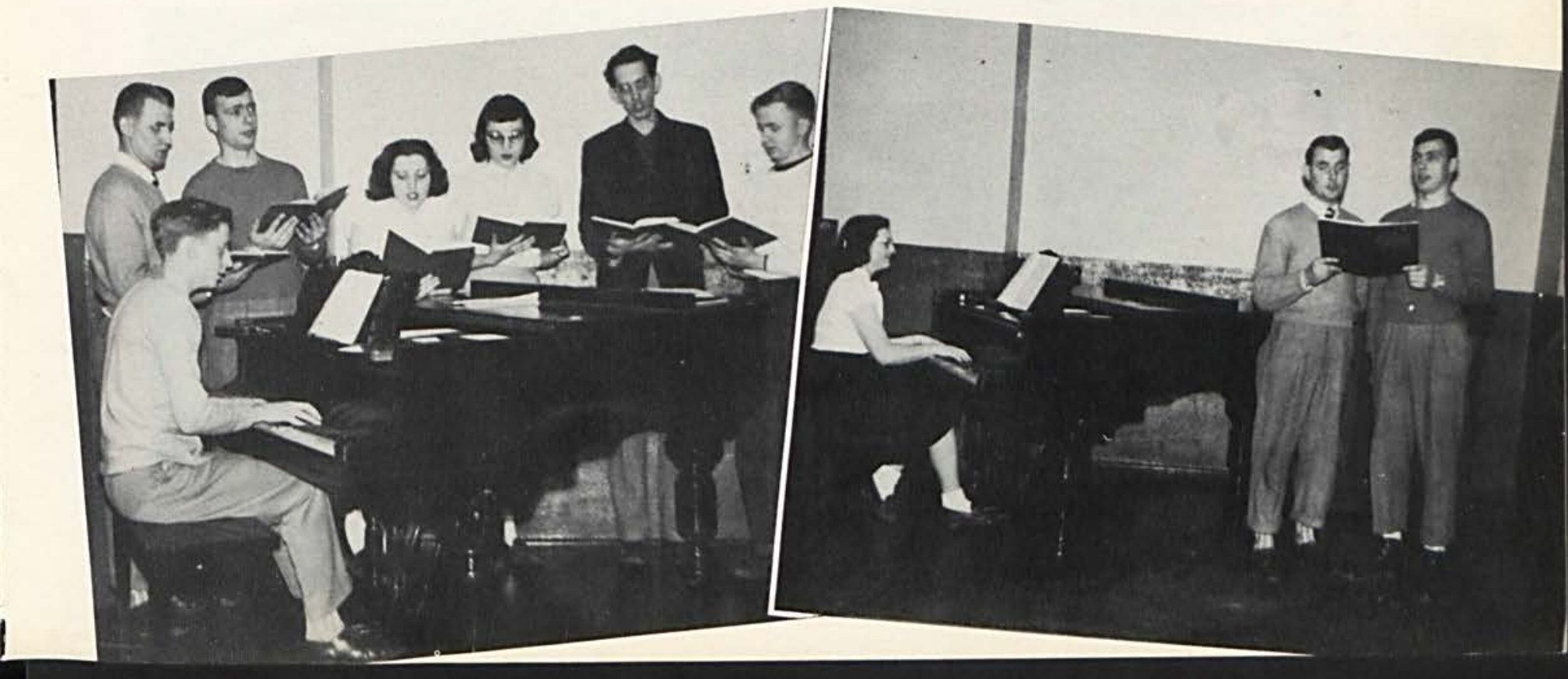




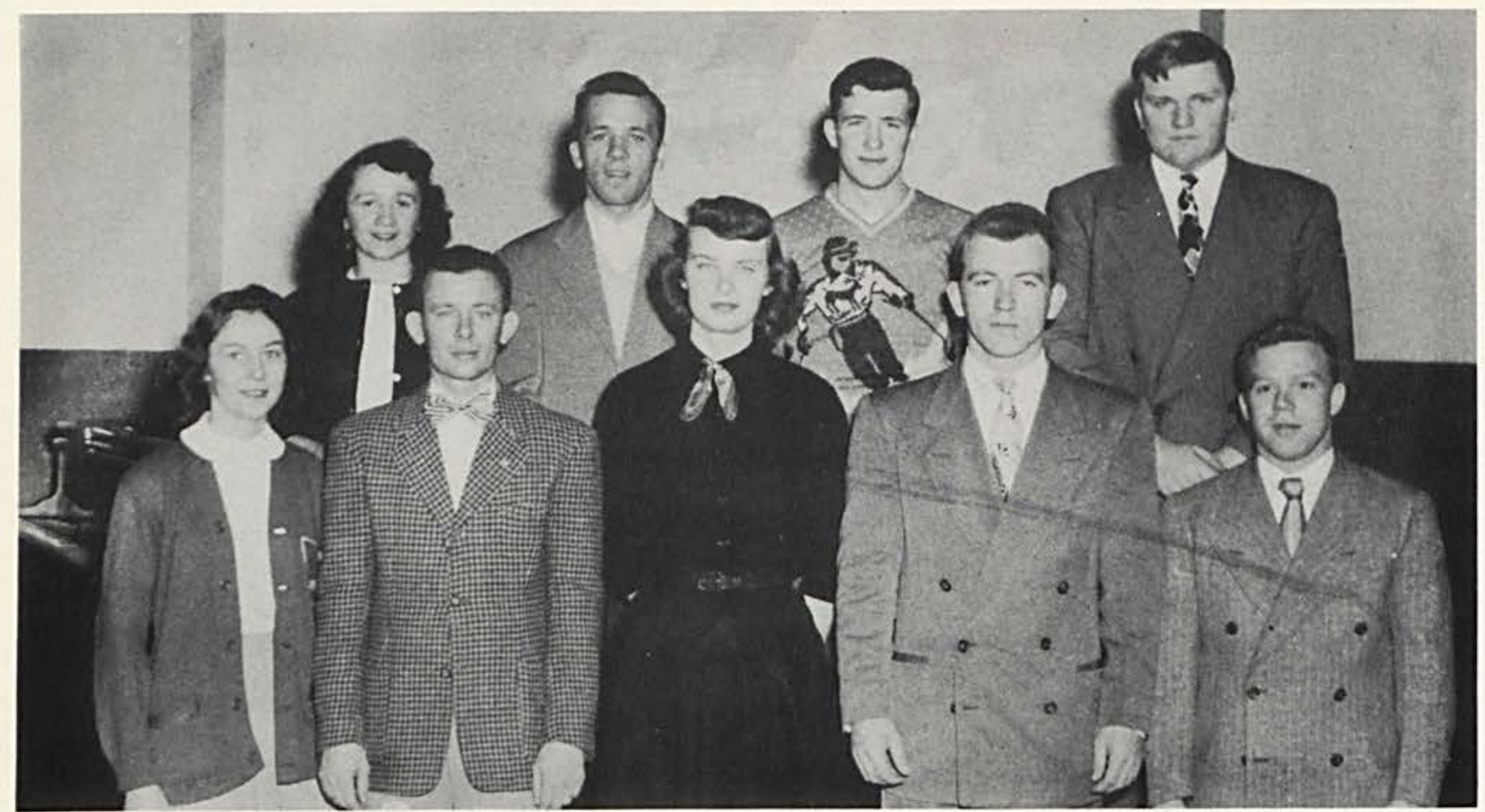

FIRST ROW: S. CAUDILL, W. OSMAN, M. L. STORMONT, M. WEIMER, D. NOCK. SECOND ROW: E. Rutan, P. DUnN, J. SHAFFER, Prof. E. SHaw.

\section{The Cedrus Staff}

The staff is proud to present the midcentury edition of The Cedrus. We sincerely hope that our efforts shall not have been in vain, and that you will cherish this volume as a collection of fond memories at Cedarville College. If you by any chance receive enjoyment from this book we wish you would kindly mention it to any member of the staff, who has been so kind and

William Osman

Editor-in-Chief

Paul Dunn

Business Manager

Edith Rutan

Art Editor

Sue Caudill

Art Editor

Mary L. Stormont

Feature Editor

Martin Weimer

Advertising Manager

James Shaffer

Photographer

Don Nock

Sports Editor

Prof. Elwood Shaw

Faculty Advisor careful in making possible our college year-book.

We wish to thank the students, faculty, advertisers, and all others for their splendid cooperation for without it this book would be impossible. We wish to especially mention and thank $\mathrm{Mr}$. Elwood Shaw for his labor and guidance.

\section{Dark Room}

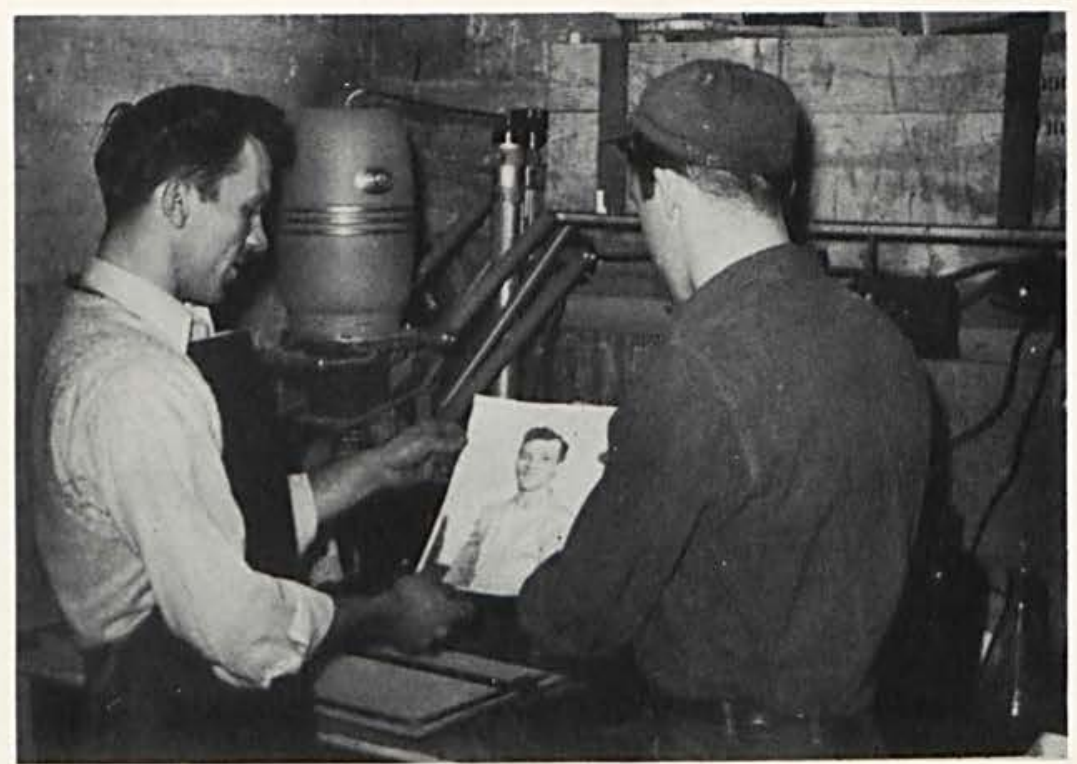




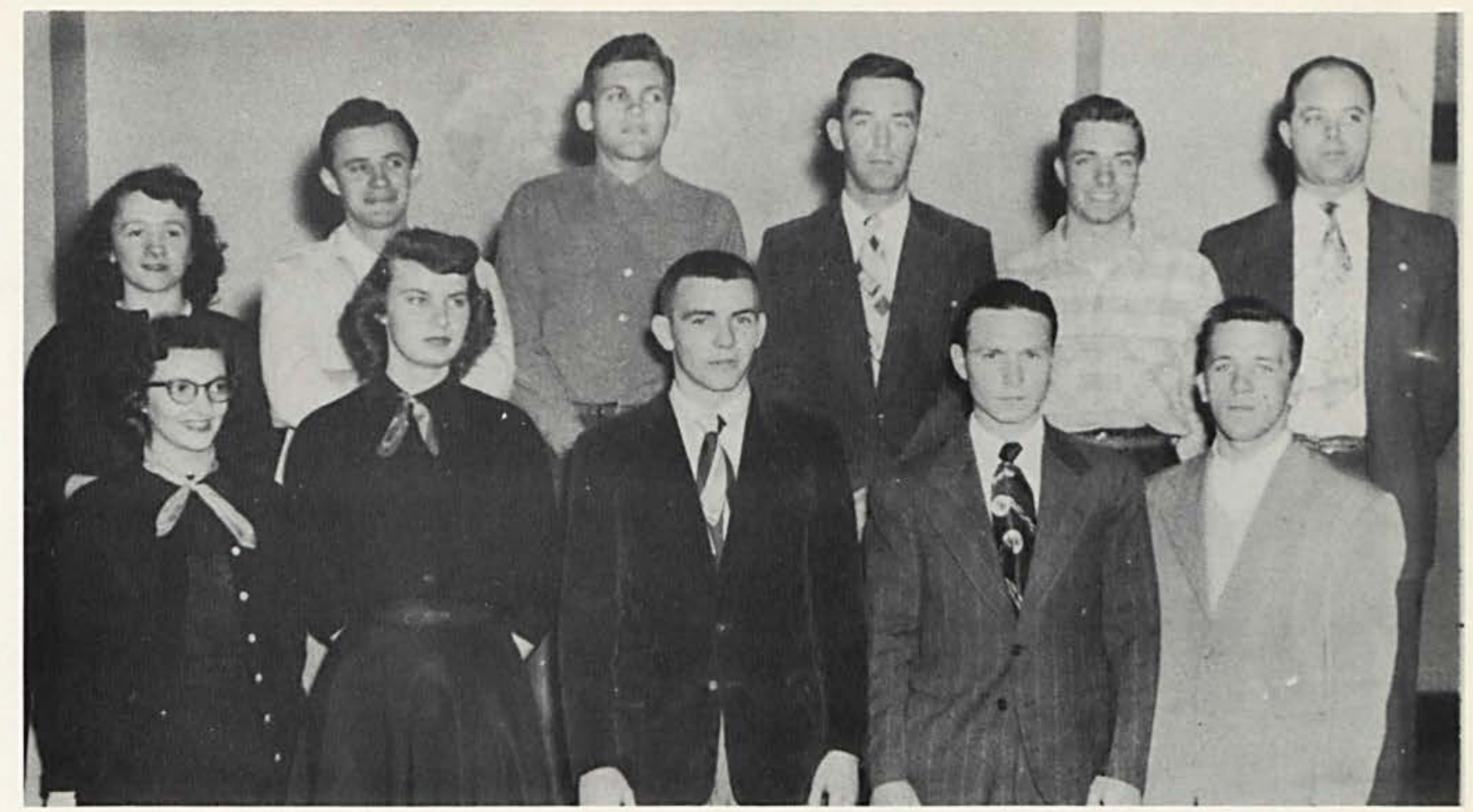

FIRST ROW: GERRY POWELL, MARY LOUISE STORMONT, DOUGLAS CULTICE, BILL CUNNINGHaM, PAUL DUNN. SECOND ROW: EDIE RUTAN, RAY GENTILE, KENNETH WILBURN, KENNETH HUfFMAN, JIM WISECUP, PROF. WISE. ABSENT FROM PICTURE: DAN MCNEAL, ROgER ULSH, DAN WEBSTER, BILL DUNLAP, LARRY BROOKS, JERRY BRADFORD.

\section{Whispering}

The "Whispering Cedars" is Cedarville College's contribution to the newspaper world. This is only the second year the paper has been in publication. In addition to its student subscribers many alumni as well as other persons interested in obtaining school news are on the mailing

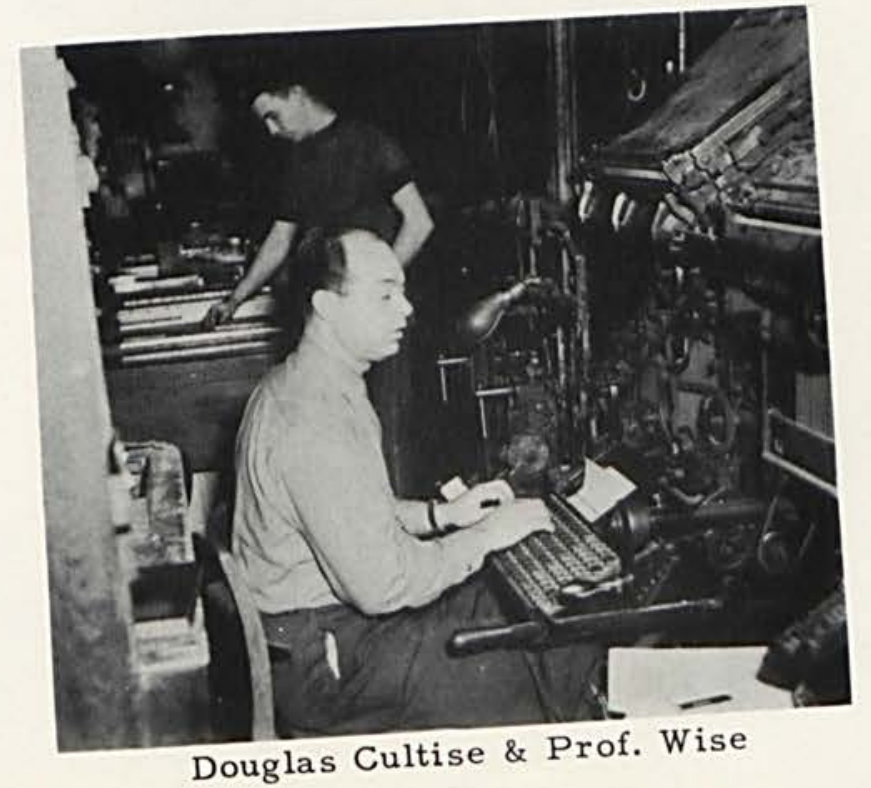

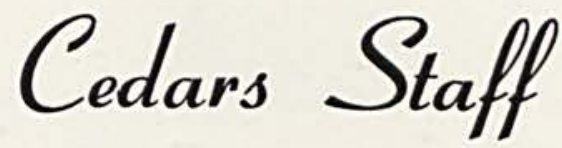

list. The publication of the paper, which is every two weeks, is always welcomed by its subscribers since it contains many columns of varied interests. This year the "Whispering Cedars" was edited by Kenneth Huffman under the direction of Prof. Wise, the faculty advisor.

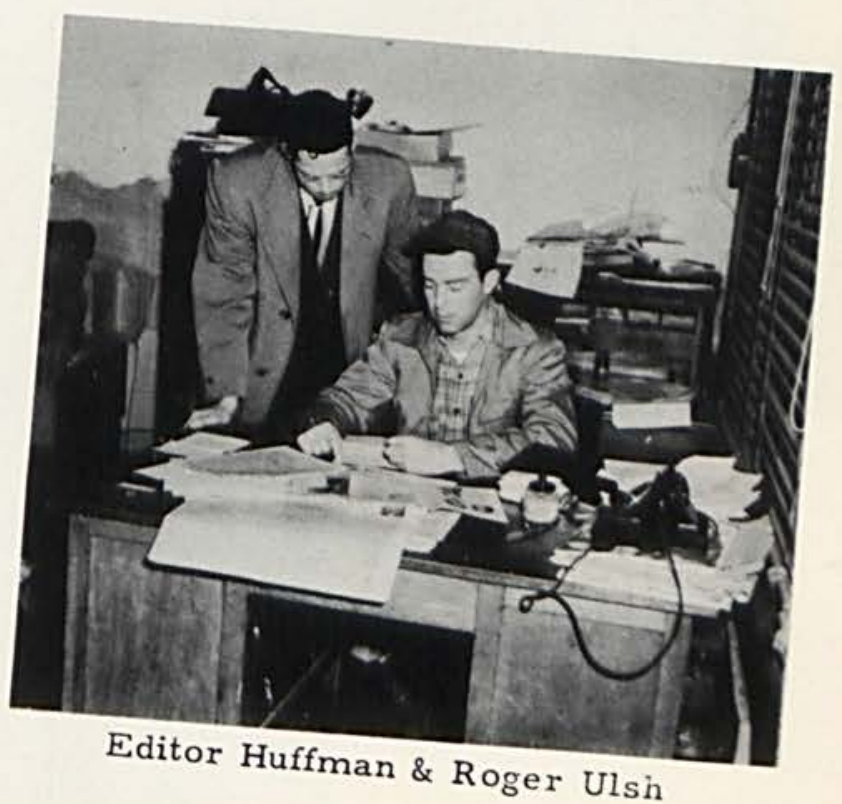




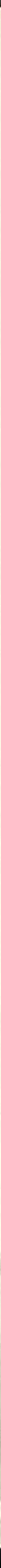




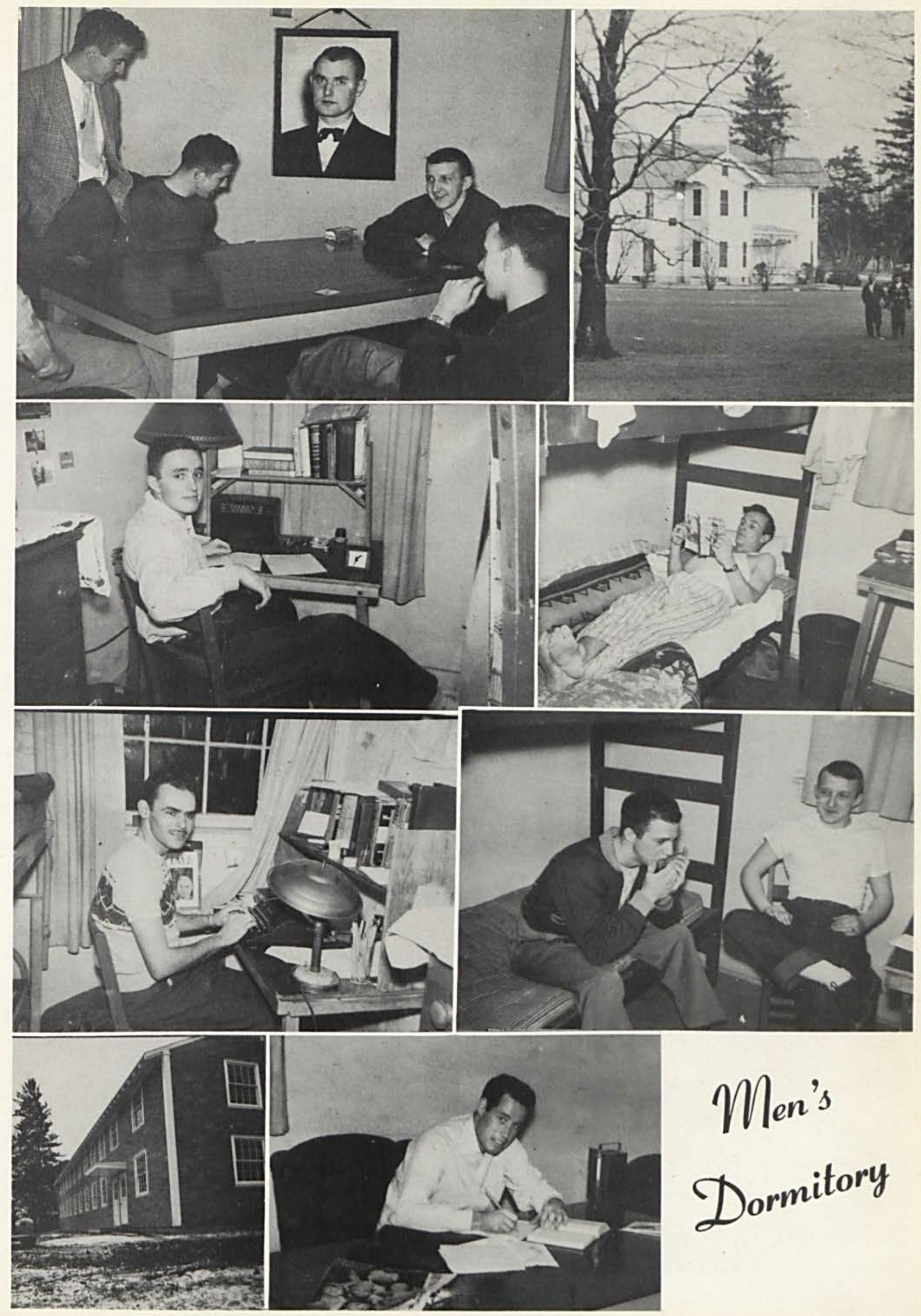




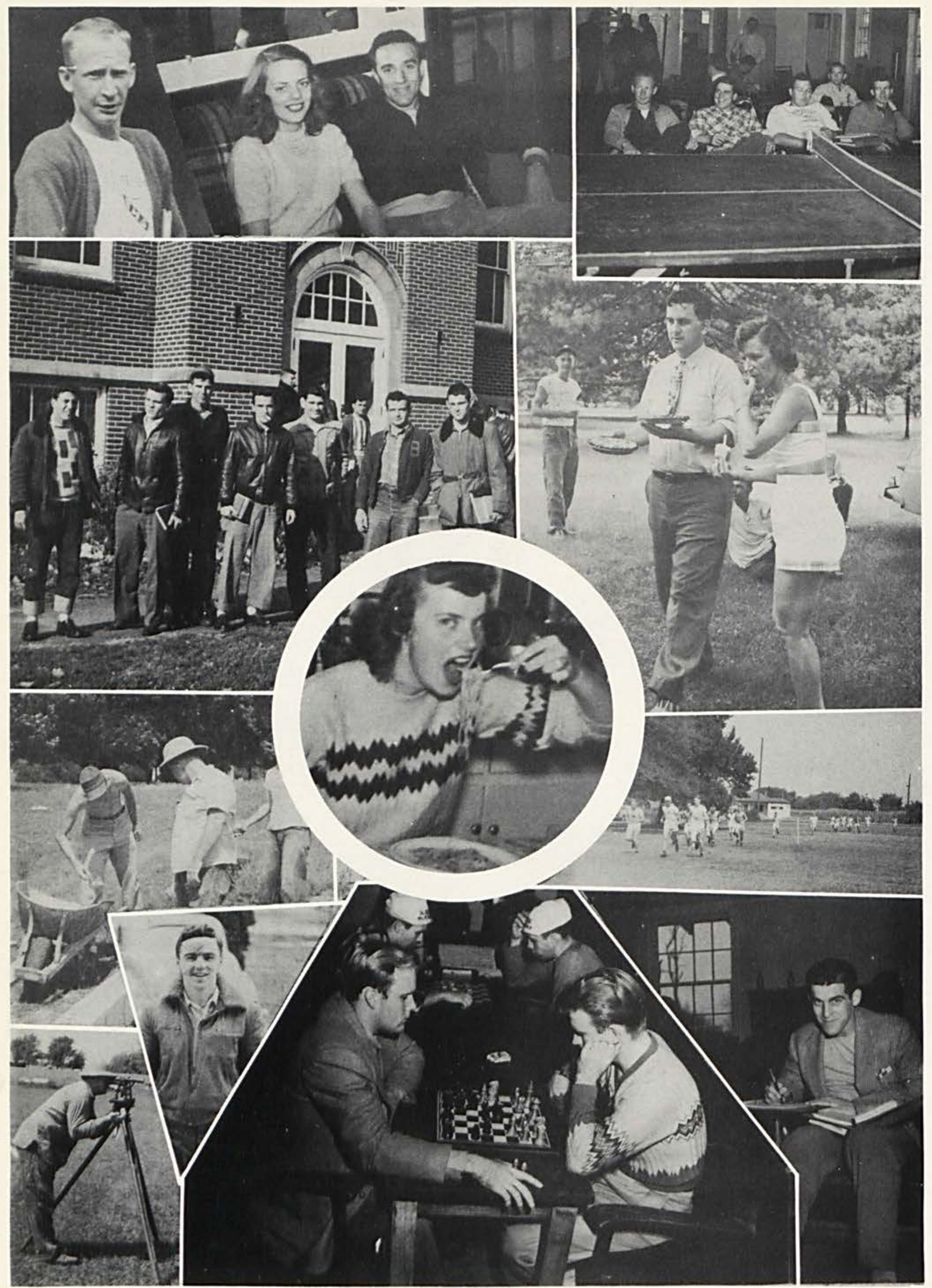



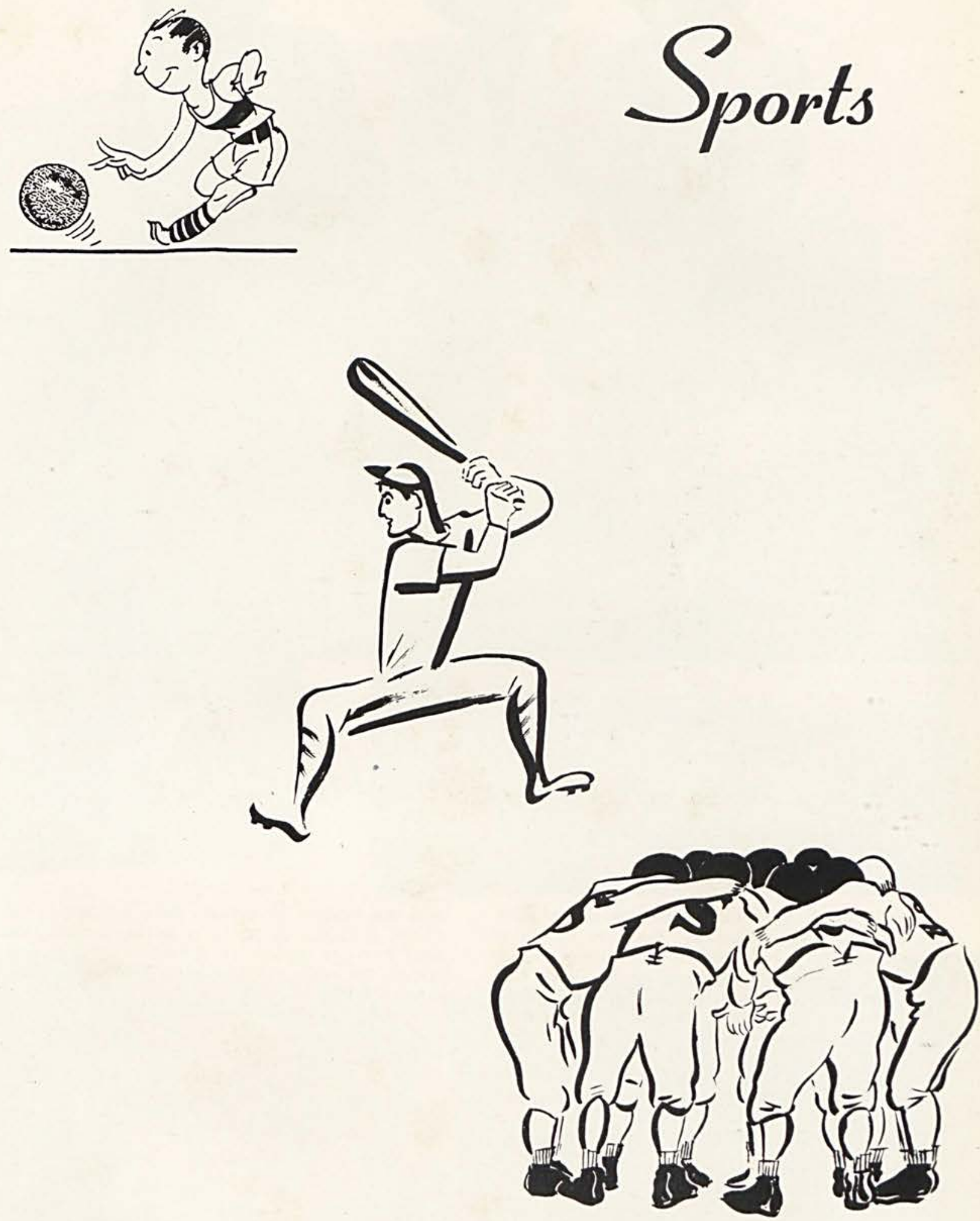

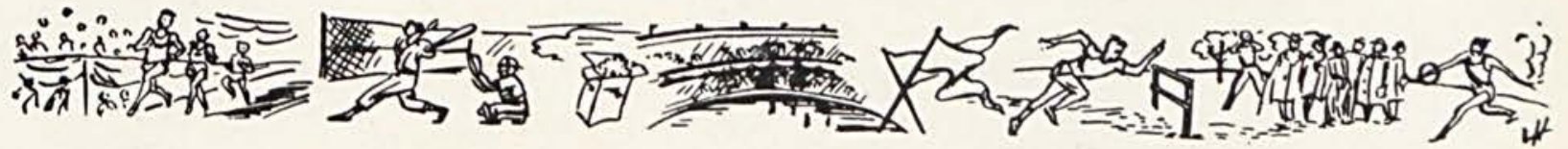




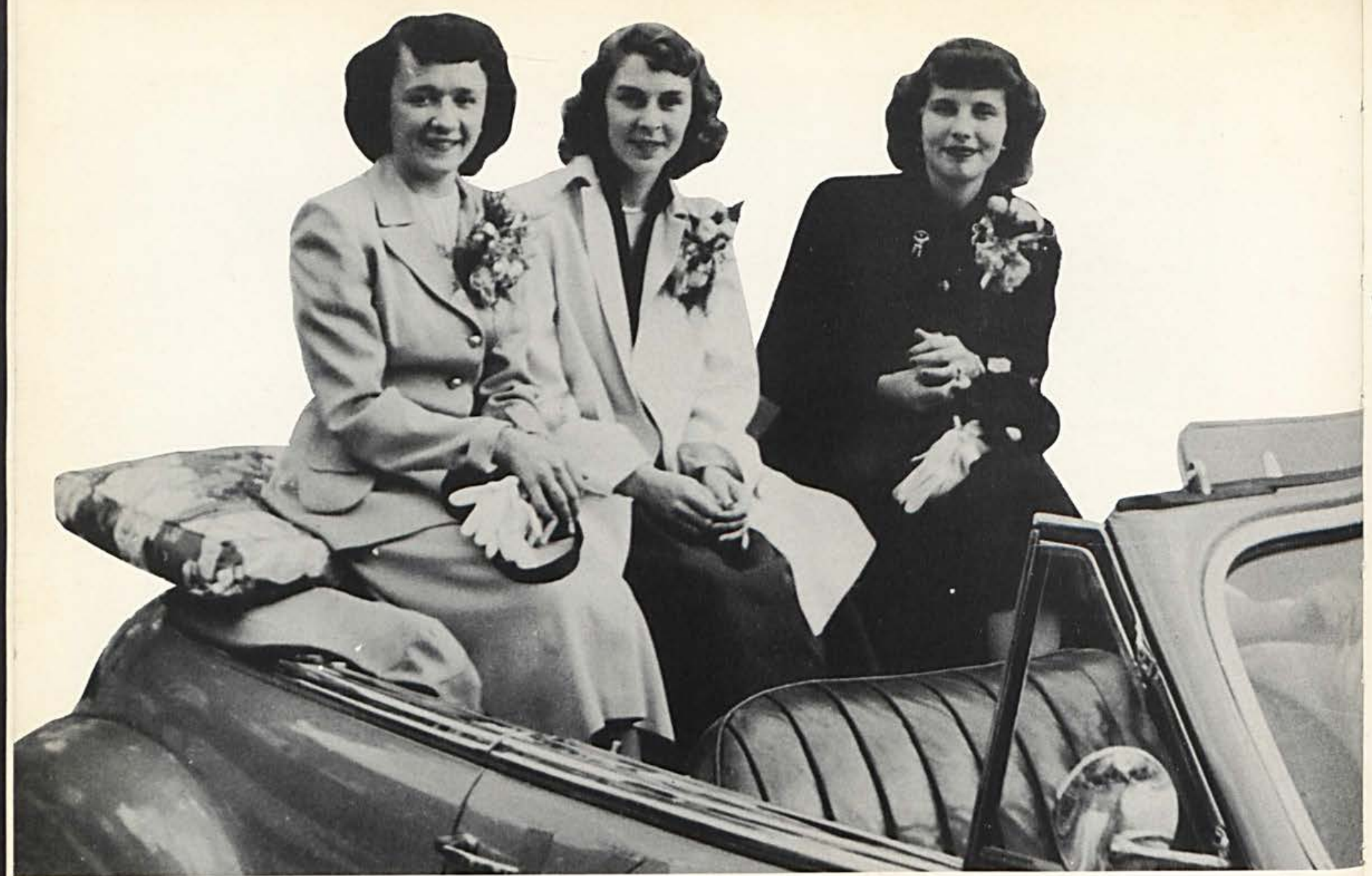

MISS eloise RUtan, MISS SUe CaUdiLl, QUeEn, MISS PHyLlis BRyant.

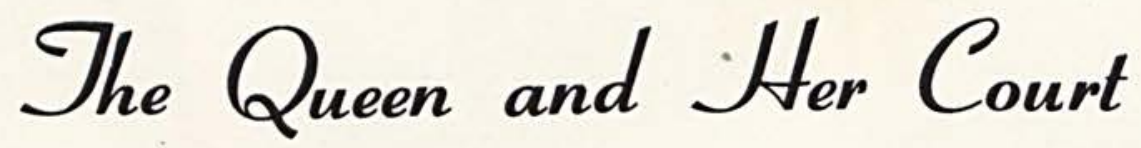

THE CEDARVILLe COLLEGe hOMECOMING OF 1949 WAS LABELED A GREAT SUCCESS. FESTIVITIES BEGAN ON THE EVENING OF OCTOBER 7 WITH A PEP RALLY AROUND A BONFIRE AND A SNAKE DANCE ABOUT THE TOWN. HOMECOMING DAY WAS ONE MADE TO ORDER: WARM, BRIGHT, AND CLEAR. THE MARCHING BANDS OF CEDARVILLE AND SPRING VALLEY HIGH SCHOOLS PERFORMED PRECEDING THE AFTERNOON FESTIVITIES. THE PARADE, LED BY THE QUEEN AND HER ATTENDANTS, FORMED DOWN TOWN AND PROCEEDED TO THE COLLEGE GRIDIRON WHERE THE FOOTBALL GAME WITH OUR RIVAL, BLUFFTON, WAS PLAYED. DURING THE HALF, THE QUEEN,
Miss Sue Caudill of Cleves, OHIO AND her atTienDANTS, MISS ELOISE RUTAN OF MECHANICSBURG, AND MISS PHYLLIS BRYANT OF CEDARVILLE, WERE PRESENTED. THE QUEEN WAS CROWNED BY LEO SHAUGHNESSY, CAPTAIN OF THE FOOTBALL TEAM.

THE FESTIVITIES OF THE DAY WERE CLIMAXED BY A HOMECOMING BANQUET IN THE ALFORD MEMORIAL GYMNASIUM AT 6:30 O'CLOCK AND A STUDENT - ALUMNI DANCE IN THE CEDARVILLE HIGH SCHOOL AUDITORIUM.

THE STUDENT COUNCIL WITH THE HELP OF ALL STUDENT ORGANIZATIONS WAS RESPONSIBLE FOR THE SUCCESS OF THE DAY.

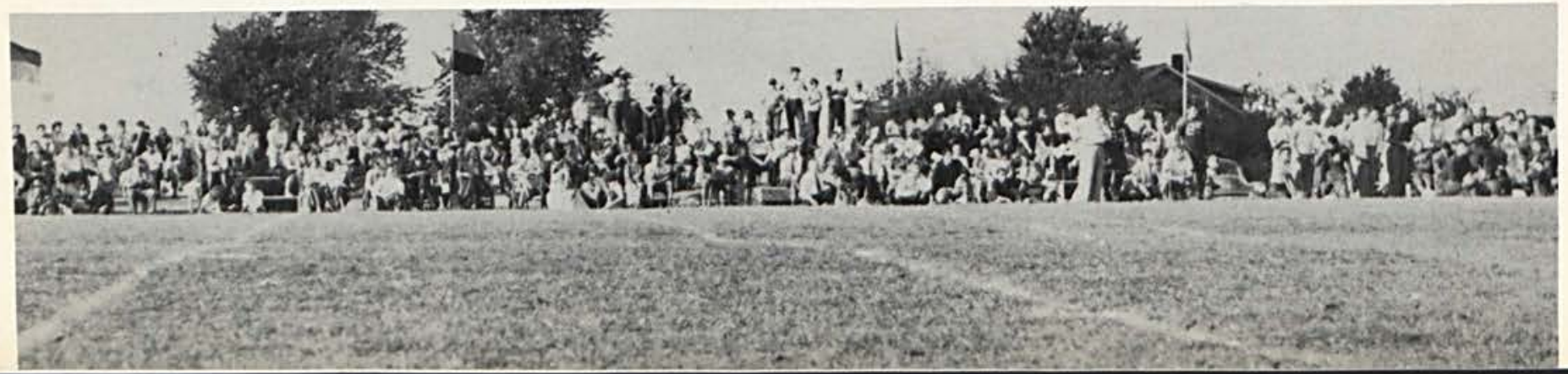




\section{Homecoming}

\section{Testivities}

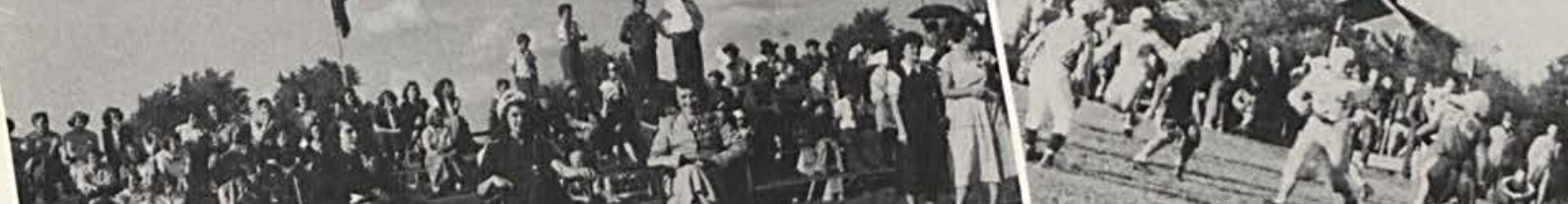
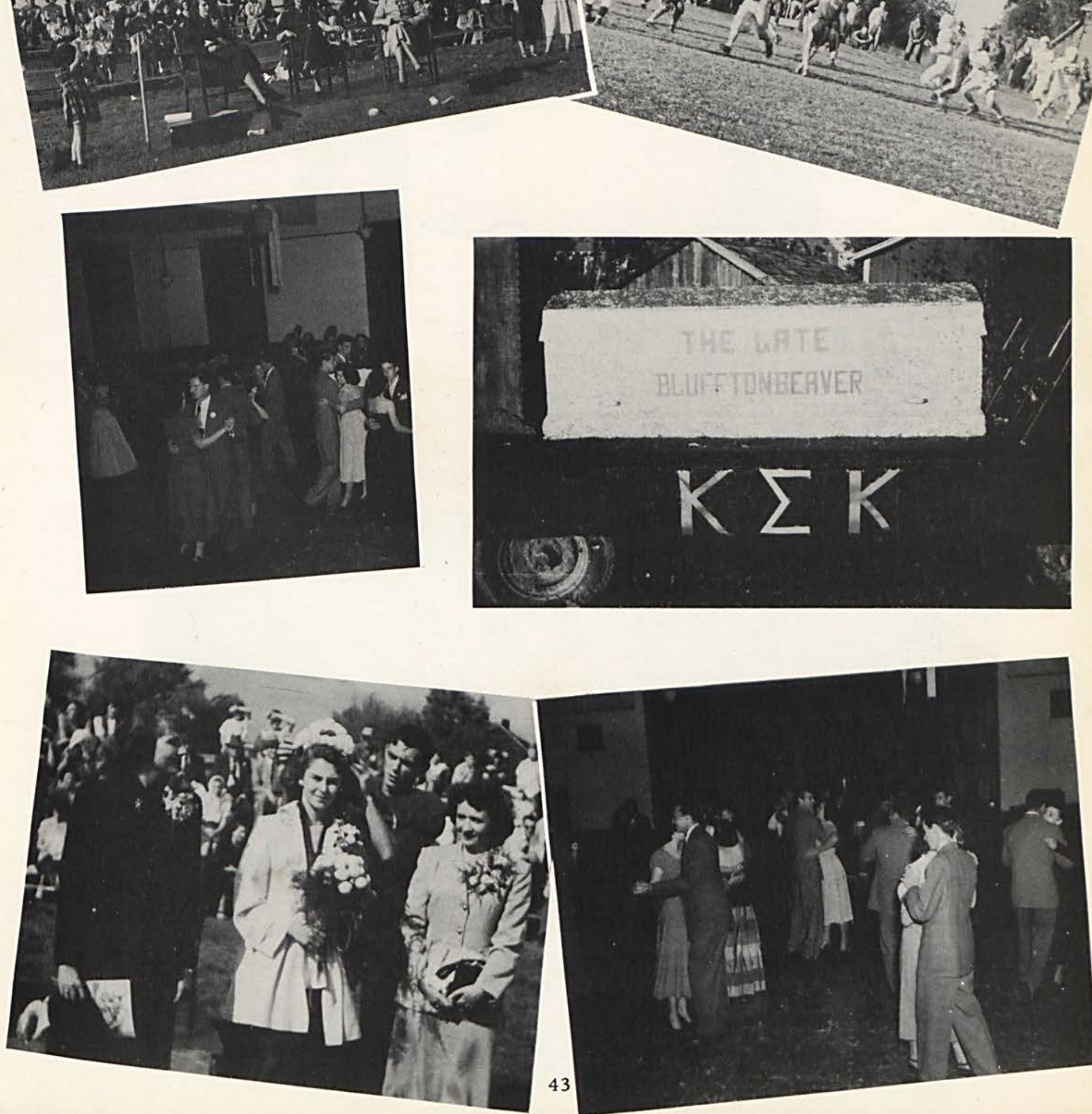


\section{Football}
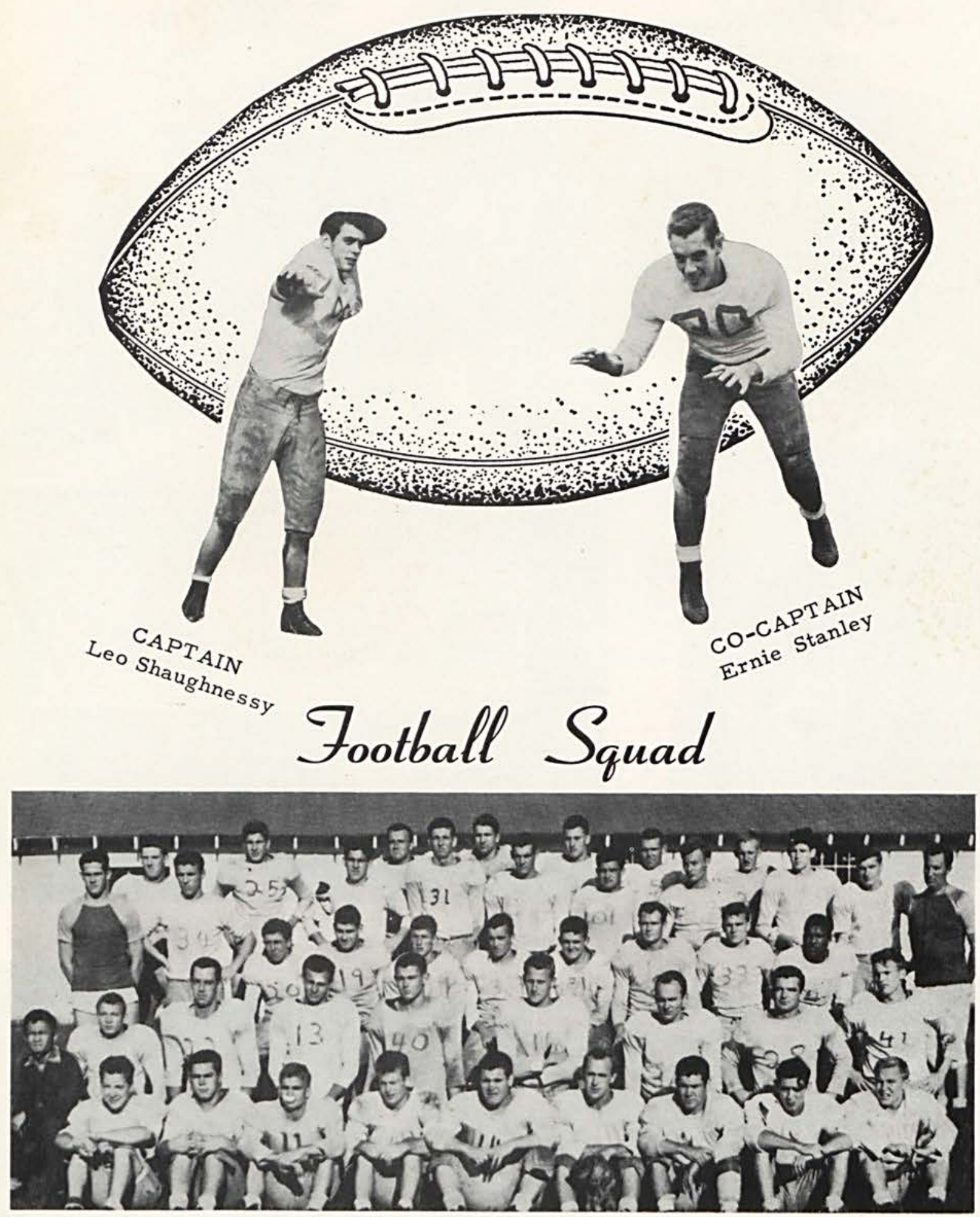

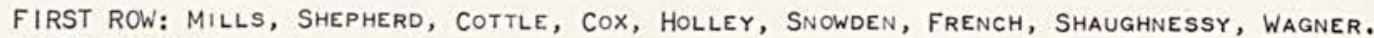
SECOND ROW: LUM, COLley, HUfFMAN, AlBright, COE, OSBORNE, ThOMPSON, KuRS, R. THOMPSON. THIRD ROW: W. EVANS-ASST. COACH, CARPENTER, MISHOS, KING, BEATTIE, WAITE, B. EVANS, HAMMOND, WOODS, BURTON. FOURTH ROW: PIENS, LAWSON, PETERS, HARTMAN, TOWNSLEY, BLATERIC,

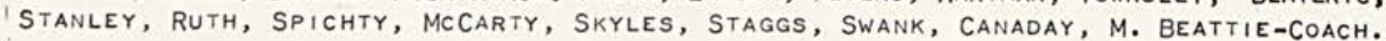




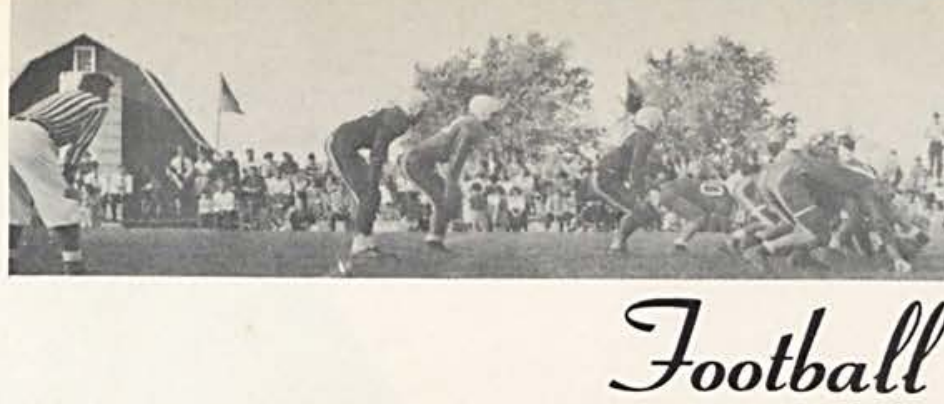

CEDARVILLE COLLEGE OPENED ITS FOOTBALL SEASON AGAINST A POWERFUL MOREHEAD ELEVEN AND MANAGED TO HOLD ITS OWN, TRAILING BY THE SCORE OF 7-6 AT THE HALFTIME. SIZE BEGAN TO TELL IN THE THIRD QUARTER AND WHEN THE FINAL GUN WENT OFF MOREHEAD HAD SCORED 22 MORE POINTS TO DEFEAT THE MUCH SMALLER CEDARVILLE ELEVEN BY THE SCORE OF 29-6.

IN THE NEXT GaME OF THE SEASON CEDARVILLE WAS AGAIN OVERPOWERED BY A MUCH LARGER OHIO NORTHERN TEAM, SCORING ONLY 2 POINTS IN THE FIRST HALF AND HELD SCORELESS IN THE SECOND HALF, CEDARVILLE WAS ON THE SHORT END OF THE 42-2 SCORE.

IN THE THIRD GAME OF THE YEAR CEDARVILLE AND GEORGETOWN, KENTUCKY FOUGHT A VICIOUS BATTLE BUT NEITHER ONE WAS ABLE TO REACH PAY DIRT. THE GAME ENDED IN A O-O DEADLOCK.

ASHLAND WAS THE OPPONENT FOR THE YELLOW JACKETS IN ITS FIRST MID-OHIO CONFERENCE GAME. CEDARVILLE PLAYERS LOOKED IMPRESSIVE IN THE FIRST HALF AS THEY JUMPED TO A $14-7$ LEAD AT HALFTIME. A GREATLY INSPIRED ASHLAND TEAM TOOK THE FIELD AT THE BEGINNING OF THE SECOND HALF AND THIS COMBINED WITH THE BOGGING DOWN OF CEDARVILLE'S DEFENSE ENABLED THEM TO TIE THE SCORE AT 14-14 AND THEN GO ON AHEAD TO A 32-14 LEAD. A TIRED CEDARVILLE ELEVEN FOUGHT BACK AND SCORED ONCE AGAIN BEFORE THE GAME ENDED BUT THIS STILL WAS NOT SUFFICIENT AND WHEN THE GUN WENT OFF THE SCORE READ 32-21.

CEDARVILLE TOPPED OFF ALL THE HOMECOMING ACTIVITIES IN GRAND STYLE AS THEY SCORED AN IMPRESSIVE 34-0 WIN OVER THE BLUFFTON BEAVERS. NO ONE WAS IN DOUBT FROM THE FIRST KICKOFF TO THE FINAL GUN AS TO WHO WAS GOING TO WIN THE GAME ESPECIALLY IN THE CEDARVILLE STANDS. IT WAS HOMER BURTON WHO DID MOST OF THE SCORING DURING THE AFTERNOON BEHIND THE HARD BLOCKING AND TACKLING OF HIS TEAMMATES. THIS WAS CEDARVILLE'S INITIAL VICTORY IN THE MID-OHIO CONVERENCE AS WELL AS IN THE 1949 SEASON.

FINDLAY, THE MID-OHIO CONFERENCE LEAGUE WINNERS FURNISHED THE OPPOSITION FOR CEDARVILLE'S THIRD LEAGUE GAME AND OPPOSITION IT WAS, THE YELLOW JACKETS WERE NEVER IN THE BALL GAME. THEY FOUGHT A HARD BUT LOSING BATTLE BUT THEY COULD NOT COPE WITH THE TRICKY OFFENSE AND HARD DEFENSE OF THE OILERS AND FINALLY BOWED TO A 42-O DEFEAT, THE WORST OF THE CURRENT SEASON.

PLAYING THEIR SECOND GAME ON THEIR HOME FIELD THE YELLOW JACKETS MET AND DEFEATED THE MUCH HEAVIER HUNTINGTON, INDIANA TEAM BY AN IMPRES-
SIVE 28-14 SCORE. IT WAS A HARD FOUGHT BATTLE BY BOTH TEAMS WITH BURTON, WAGNER AND COE TALLYING THE POINTS FOR CEDARVILLE AND STANLEY, KING, AND BLATERIC CARRYING THE BLUNT OF THE DEFENSIVE PLAY, THE YELLOW JACKETS EMERGED THE VICTORS FOR THE SECOND TIME THIS SEASON, BOTH ON THEIR OWN GRIDIRON.

ON OCTOBER 29 CEDARVILLE MET THEIR BITTER RIVALS, THE QUAKERS OF WILMINGTON, IN AN "AFTER OF EVERYTHING" BUT FOOTBALL, WHERE THE OFFICIALS PACED OFF MORE YARDAGE THAN EITHER TEAM GAINED. IN THIS GAME WHERE EMPHASIS WAS PUT ON ROUGHNESS INSTEAD OF FOOTBALL THE YELLOW JACKETS MANAGED TO SCORE BUT ONE TOUCHDOWN WHILE THE QUAKERS TALLIED FIVE TIMES WITH TWO EXTRA POINTS TO HAND THE YELLOW JACKETS THEIR FIFTH LOSS OF THE SEASON.

THE YELLOW JACKETS OF CEDARVILLE JOURNEYED TO TERRE HAUTE, INDIANA TO PLAY THE ENGINEERS OF ROSE POLY. THE HOST CLUB PROMPTLY TOOK THE LEAD BUT ONLY BY ONE POINT 7-6; THEN ROSE POLY SCORED THREE TOUCHDOWNS TO CEDARVILLE'S ONE TO MAKE THE SCORE AT THE HALFTIME $27-12$ IN FAVOR OF ROSE POLY. A NEW AND INSPIRED TEAM TOOK THE FIELD FOR CEDARVILLE IN THE SECOND HALF AND QUICKLY SCORED THREE TOUCHDOWNS TO GO AGEAD 32-27. THEN WITH BUT FIVE MINUTES REMAINING IN THE GAME ROSE POLY SCORED ONCE MORE TO SECURE THE WIN FROM CEDARVILLE BY A 34-32 SCORE.

IN THE FINAL GAME OF THE SEASON CEDARVILLE MET DEFIANCE TO DETERMINE THE THIRD PLACE POSITION IN THE MID-OHIO CONFERENCE LEAGUE. IT WAS A NIP AND TUCK GAME ALL THE WAY WITH THE TEAMS MATCHED ABOUT EVEN ON OFFENSE AS WELL AS ON DEFENSE, BUT BY THE END OF THE SECOND QUARTER CEDARVILLE HAD REACHED PAY DIRT ONE MORE TIME THAN DEFIANCE AND WERE AHEAD 19-13. IN THE THIRD QUARTER DEFIANCE SCORED TWICE TO CEDARVILLE'S ONCE AND THE SCORE WAS ALL TIED UP GOING INTO THE FOURTH QUARTER. THEN DEFIANCE WITH THEIR BACK TO THEIR OWN GOAL ATTEMPTED TO PUNT, BUT THE KICK WAS BLOCKED BY KENNY WOODS AND THE BALL WENT OUT OF THE END ZONE FOR AN AUTOMATIC! TWO POINTS FOR CEDARVILLE. THIS WAS ALL THEY NEEDED TO WIN AS THE FINAL SCORE WAS 28-26.

CEDARVILLE FINISHED THE SEASON IN THIRD PLACE OF THE MID-OHIO CONFERENCE AND A SEASON RECORD OF 3 WINS, 6 LOSSES, AND I TIE.

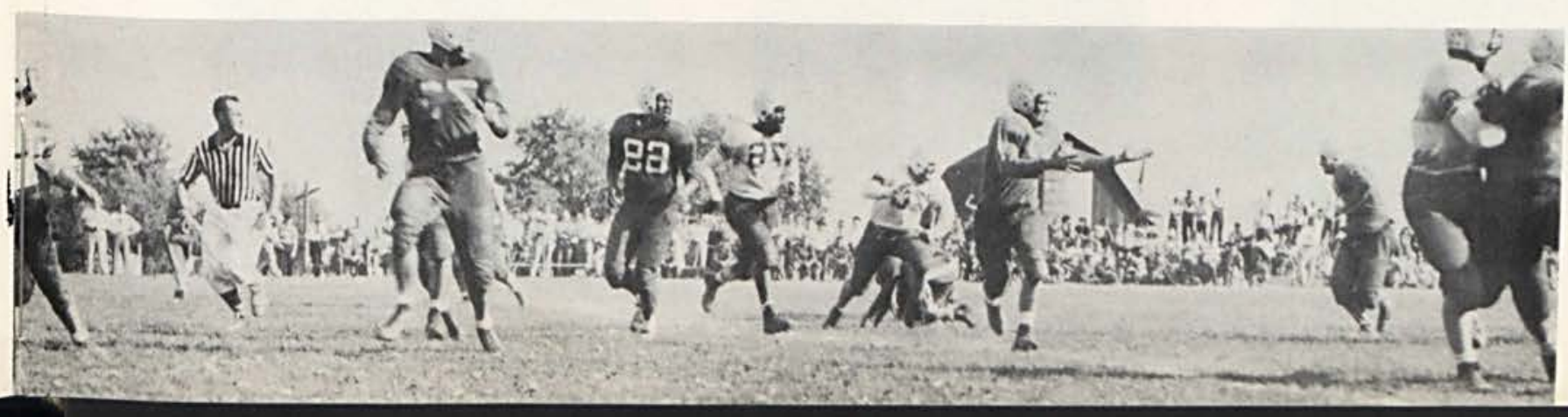




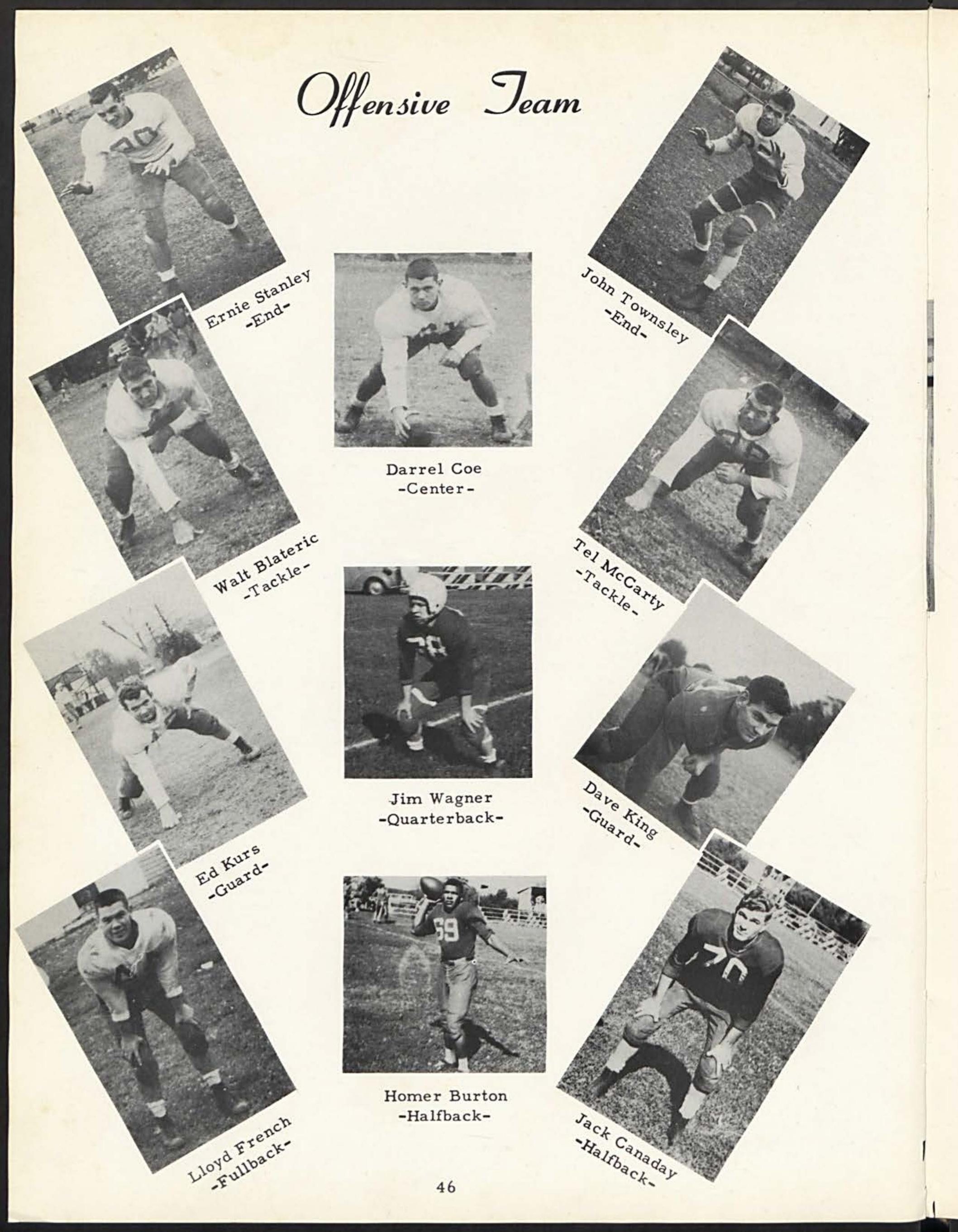




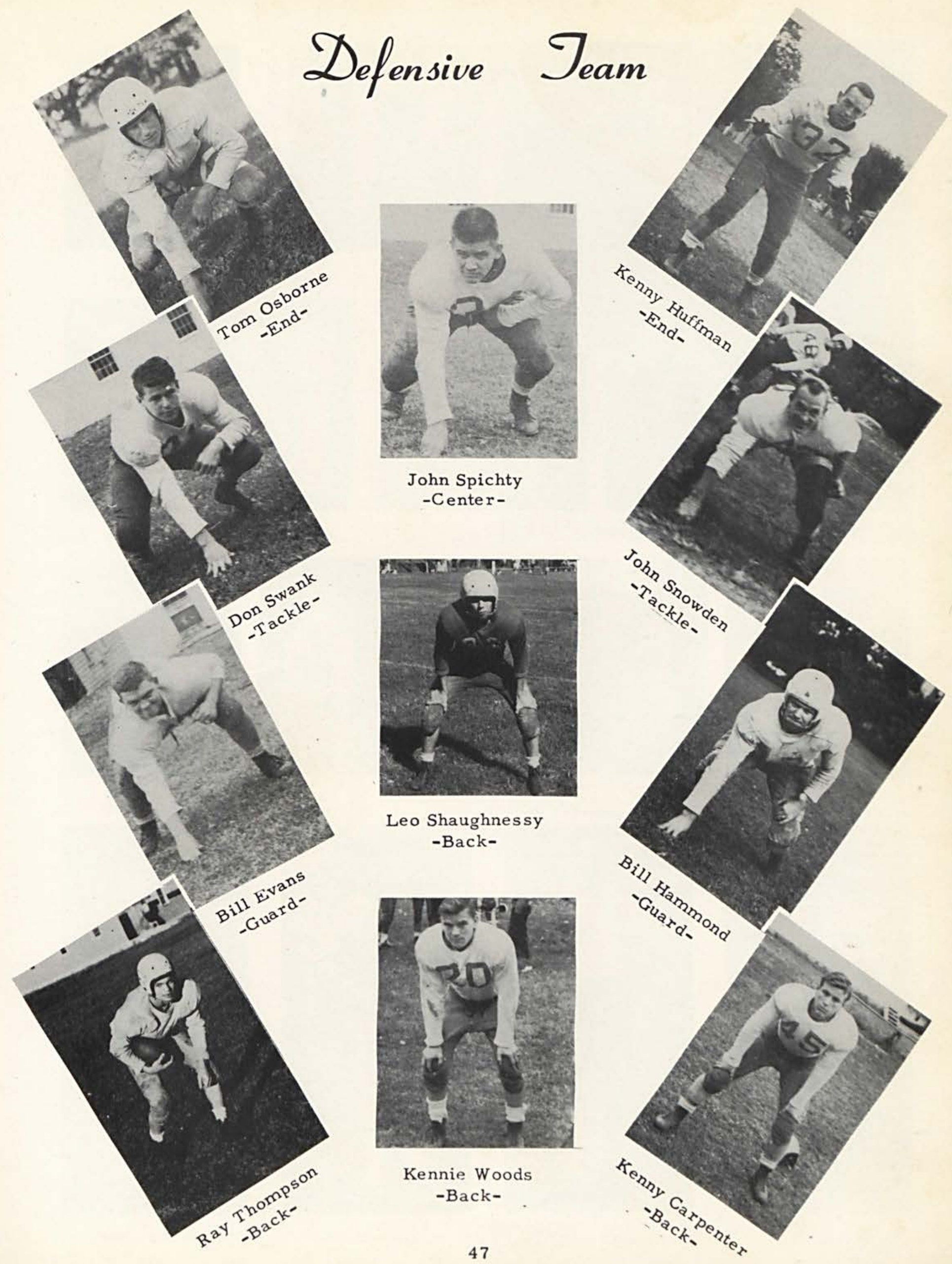



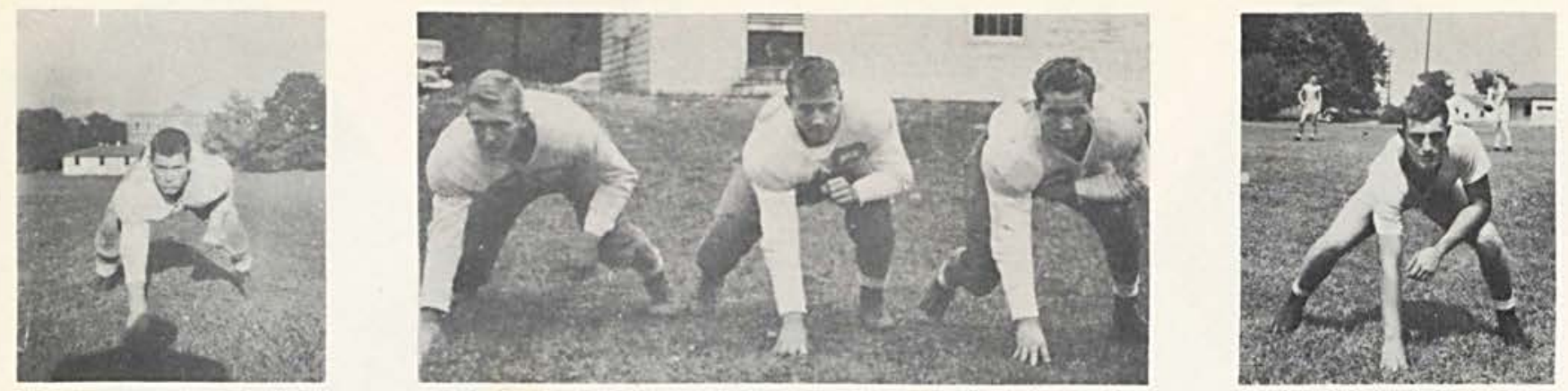

HOLLEY, TACKLE

STAGGS, END

ALBRIGHT, GUARD

MILLS, TACKLE
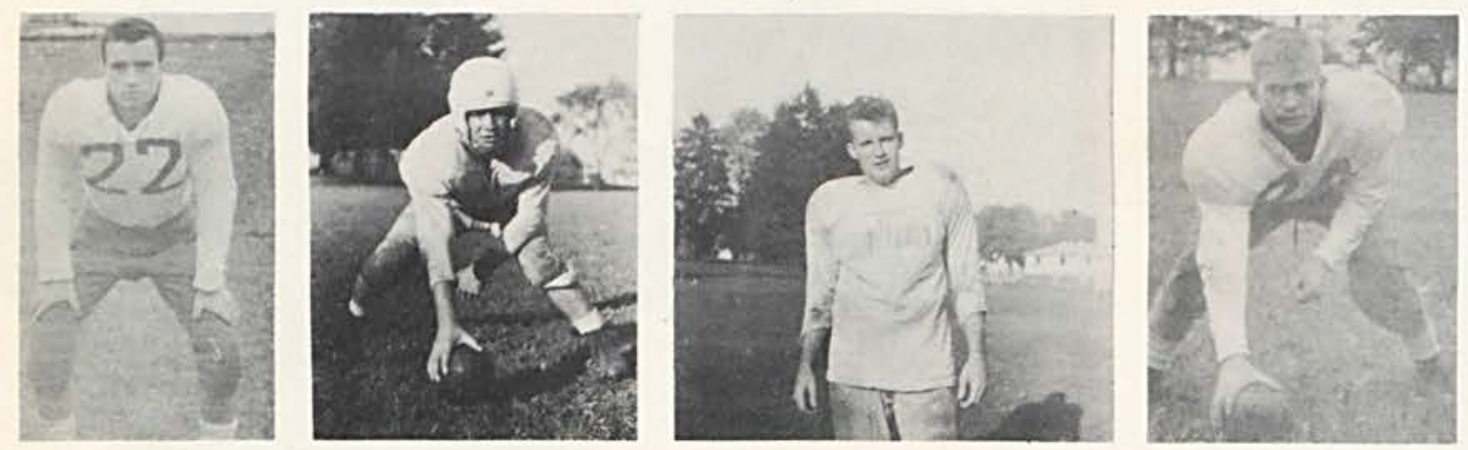

RUTH, TACKLE

WAITE, BACK

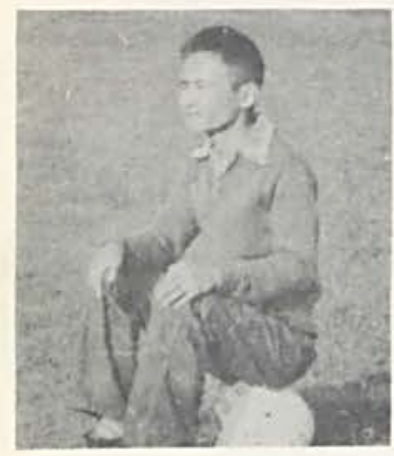

LUM, ASST. MGR.

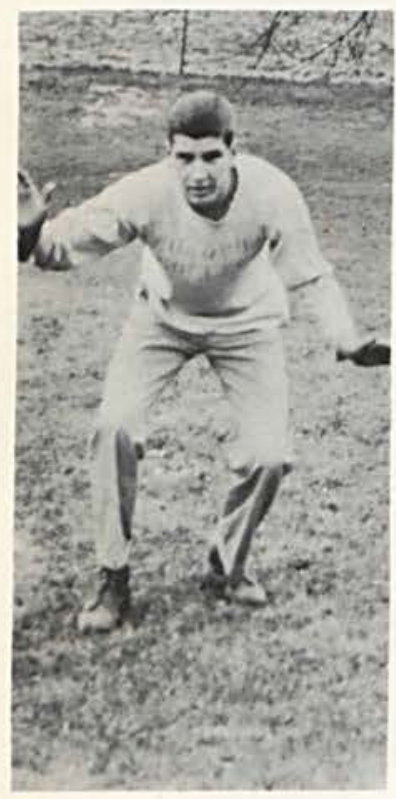

LAWSON, END
COLLEy, CENTER

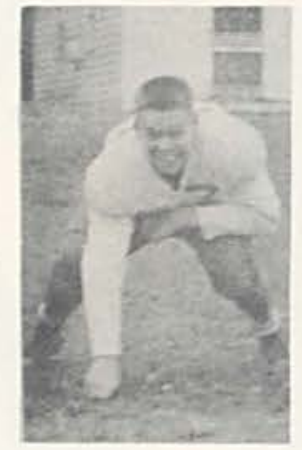

COTtLe, Center

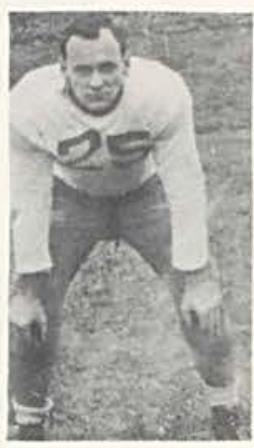

B. THOMPSON, BACK
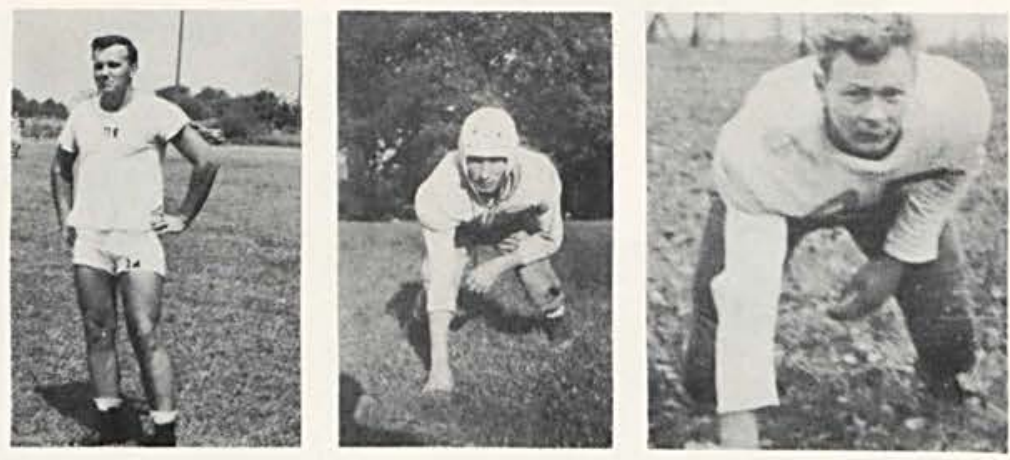

SHEPHERD, TACKLE
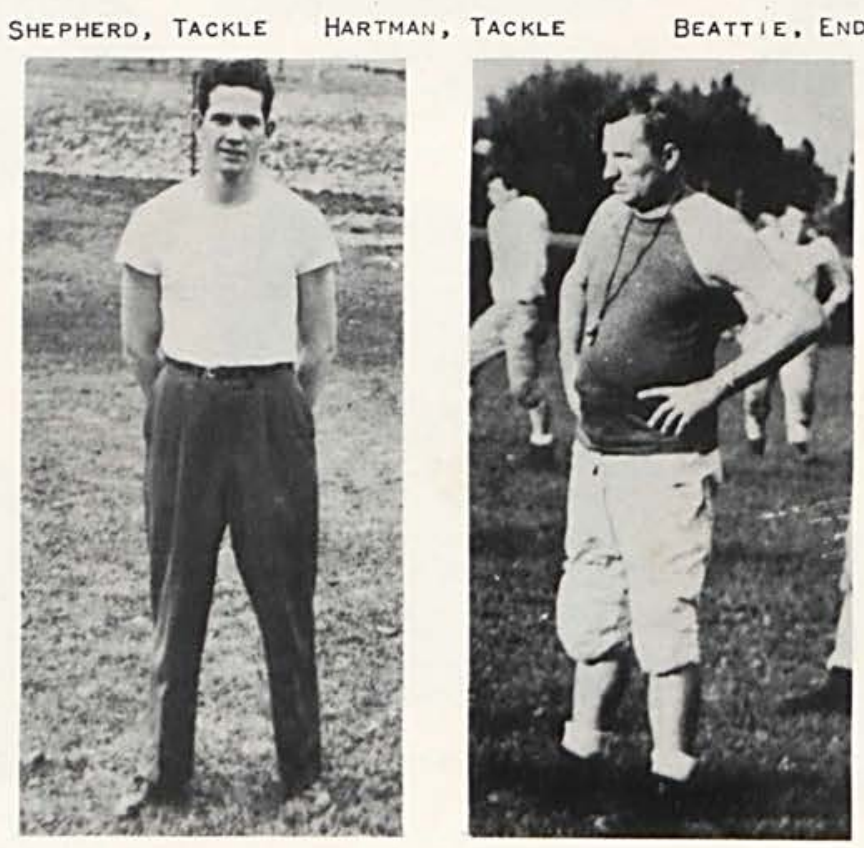

W. EVANS, ASST. COACH

SKYLES, END

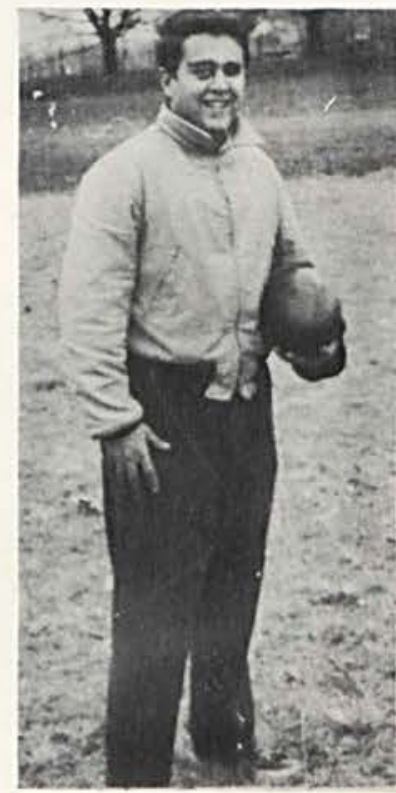

Distaola, MGR . 

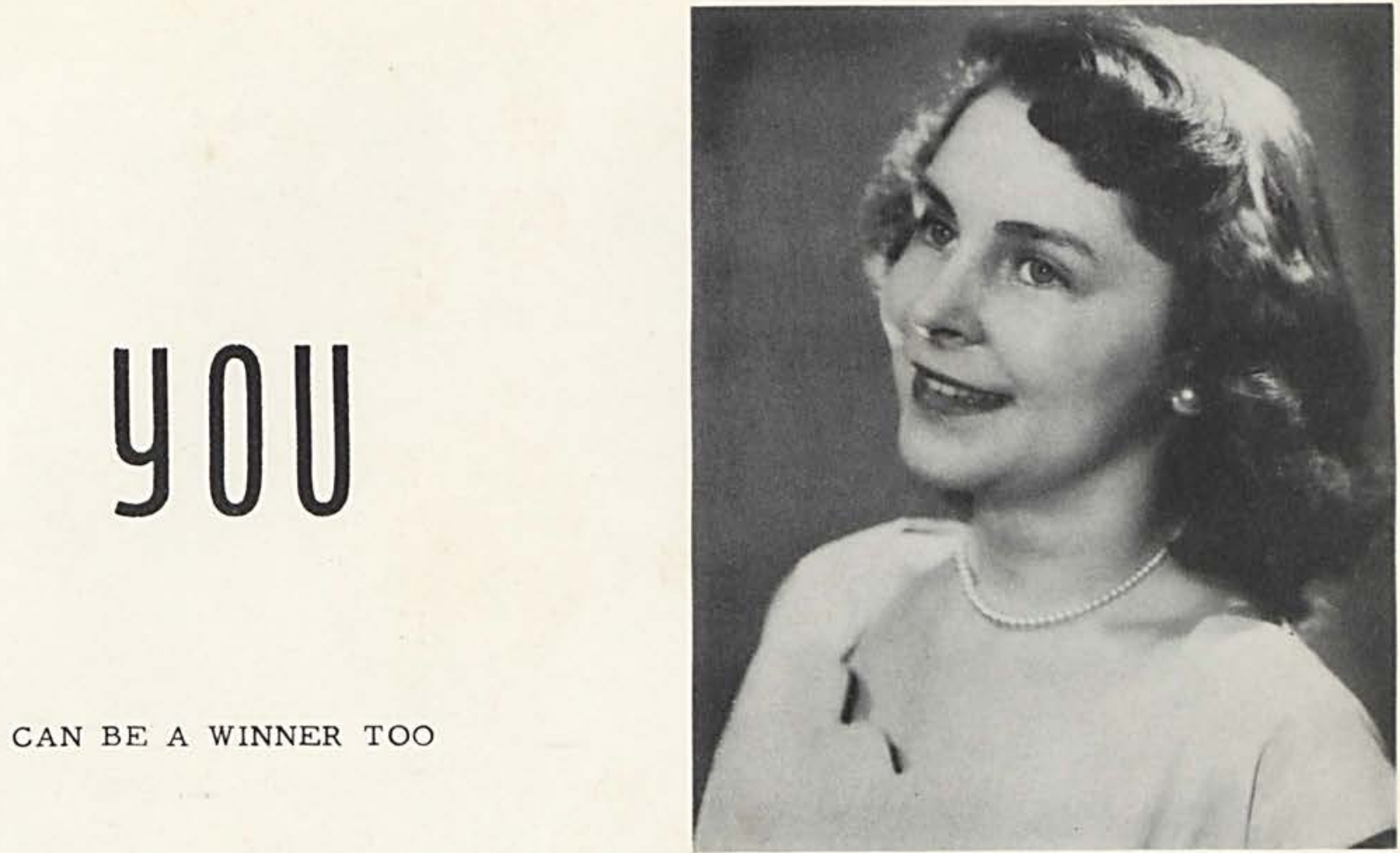

SUE CAUDILL

Football Homecoming Queen

If You Trade At

\section{THE CAMERA SHOP}

22 West Main St.

Xenia, Ohio 


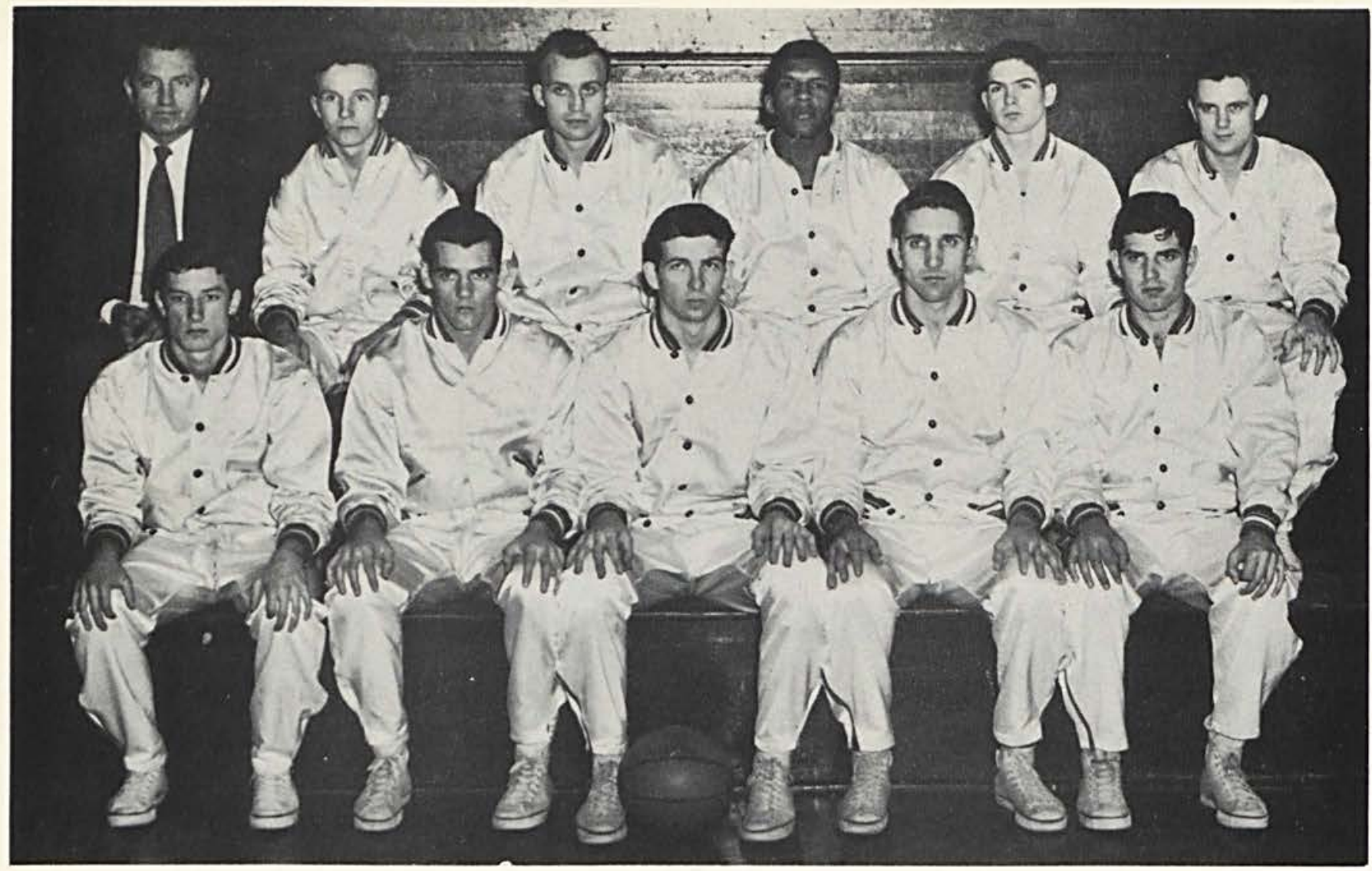

FIRST ROW: BEATTIE, STANLEY, TOWNSLEy, BLATERIC, HARNER. SECOND ROW: COACH BEATTIE, ButTs, PICKENS, BURTON, DOWNS, Dunlap. NOT IN PICTURE: Brill, hufFMAN.

\section{Varsity}

THE YELLOW JACKET CAGERS WOUND UP THEIR 194950 SEASON WITH A RECORD OF THIRTEEN WINS AND SIXTEEN LOSSES-NOT TOO BAD A RECORD WHEN YOU CONSIDER THE ONE-POINT DEFEAT AT THE HANDS OF DAYTON AND ASHLAND AND THE TWO OVERTIME DEFEATS HANDED THEM BY HUNTINGTON. THEY FINISHED IN A THIRD PLACE TIE WITH DEFIANCE IN THE MID-OHIO LOOP, BUT THE JACKETS WERE THE ONLY TEAM IN THE LEAGUE TO DEFEAT THE CHAMPION FINDLAY TEAM.
AS A TEAM THE JACKETS SCORED 1,801 POINTS FOR A 62.1 OFFENSIVE AVERAGE COMPARED TO 1,720 POINTS FOR THE OPPONENTS AND A 59.3 DEFENSIVE AVERAGE. JOHN TOWNSLEY WAS THE LEADING SCORER WITH 489 POINTS FOR THE SEASON WITH WALT BLATERIC CLOSE BEHIND WITH 407 POINTS.

PLAYING THEIR FINAL SEASON WITH THE YELLOW JACKETS WERE JOHN TOWNSLEY, WALT BLATERIC, ERNIE STANLEY, BILL DUNLAP, AND KENNETH HUfFMAN.

SEASONAL RECORD

$\begin{array}{ll}\text { CEDARVILLE } & 48 \\ \text { CEDARVILLE } & 52 \\ \text { CEDARVILLE } & 36 \\ \text { CEDARVILLE } & 52 \\ \text { CEDARVILLE } & 40 \\ \text { CEDARVILLE } & 53 \\ \text { CEDARVILLE } & 59 \\ \text { CEDARVILLE } & 61 \\ \text { CEDARVILLE } & 51 \\ \text { CEDARVILLE } & 50 \\ \text { CEDARVILLE } & 73 \\ \text { CEDARVILLE } & 71 \\ \text { CEDARVILLE } & 70 \\ \text { CEDARVILLE } & 68\end{array}$

BLISS

MOOREHEAD

UN. OF DAYTON

VILLA MADONNA

UN. OF DAYTON

ASHLAND

MORRIS HARVEY

HUNTINGTON

BEREA

ASHLAND

DEFIANCE

WILMINGTON

FINDLAY

STEUBENVILLE

CEDARVILLE 37

$\begin{array}{llr}42 & \text { CEDARVILLE } & 80 \\ 61 & \text { CEDARVILLE } & 65 \\ 50 & \text { CEDARVILLE } & 104 \\ 39 & \text { CEDARVILLE } & 65 \\ 41 & \text { CEDARVILLE } & 68 \\ 54 & \text { CEDARVILLE } & 51 \\ 85 & \text { CEDARVILLE } & 67 \\ 63 & \text { CEDARVILLE } & 46 \\ 44 & \text { CEDARVILLE } & 59 \\ 56 & \text { CEDARVILLE } & 118 \\ 67 & \text { CEDARVILLE } & 75 \\ 70 & \text { CEDARVILLE } & 64 \\ 66 & \text { CEDARVILLE } & 60 \\ 52 & \text { CEDARVILLE } & 62 \\ & \text { U. OF CINCINNATI }\end{array}$

84

$\begin{array}{ll}\text { BLUFFTON } & 43 \\ \text { BLISS } & 74 \\ \text { CHASE COLLEGE } & 45 \\ \text { HUNTINGTON } & 69 \\ \text { MOOREHEAD } & 74 \\ \text { FINDLAY } & 54 \\ \text { WILBERFORCE STATE } & 60 \\ \text { WILMINGTON } & 58 \\ \text { VILLA MADONNA } & 51 \\ \text { CHASE COLLEGE } & 44 \\ \text { DEFIANCE } & 84 \\ \text { STEUBENVILLE } & 49 \\ \text { BLUFFTON } & 72 \\ \text { WILBERFORCE STATE } & 68\end{array}$



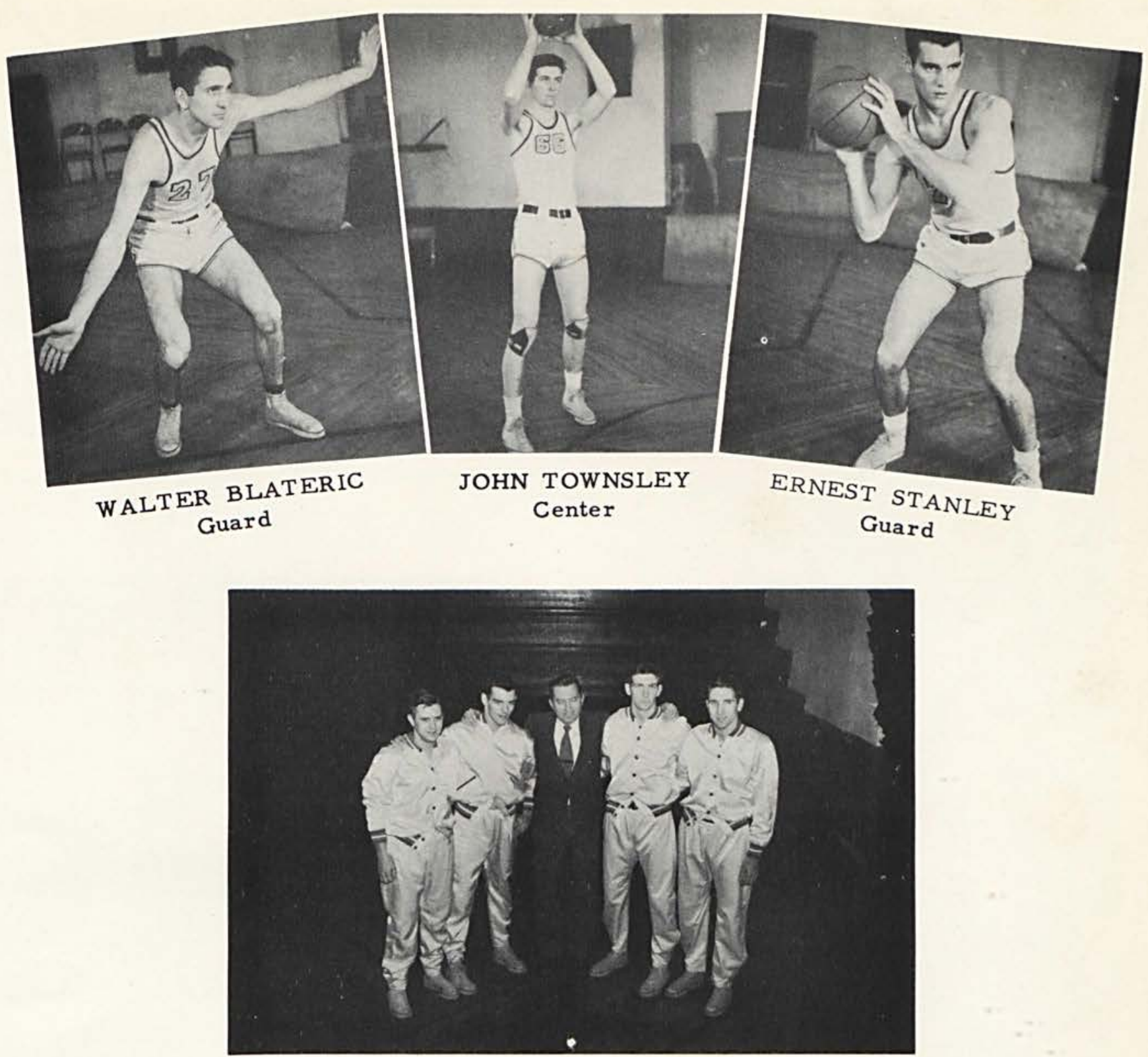

SENIORS

WILLIAM DUNLAP

Forward

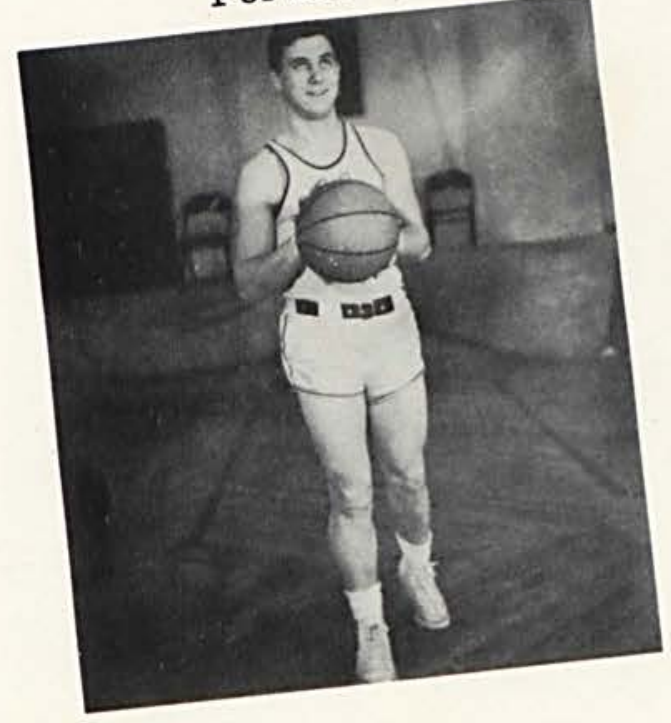

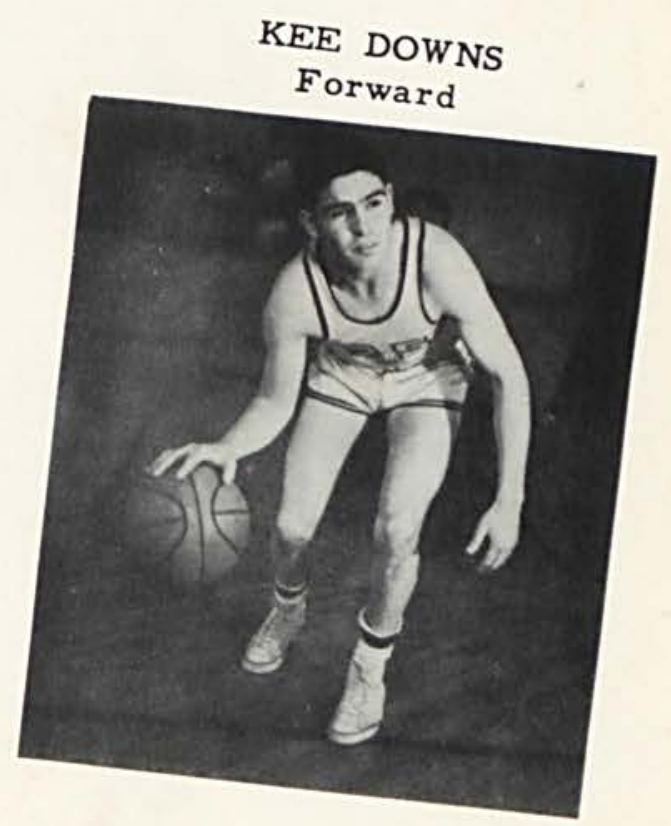




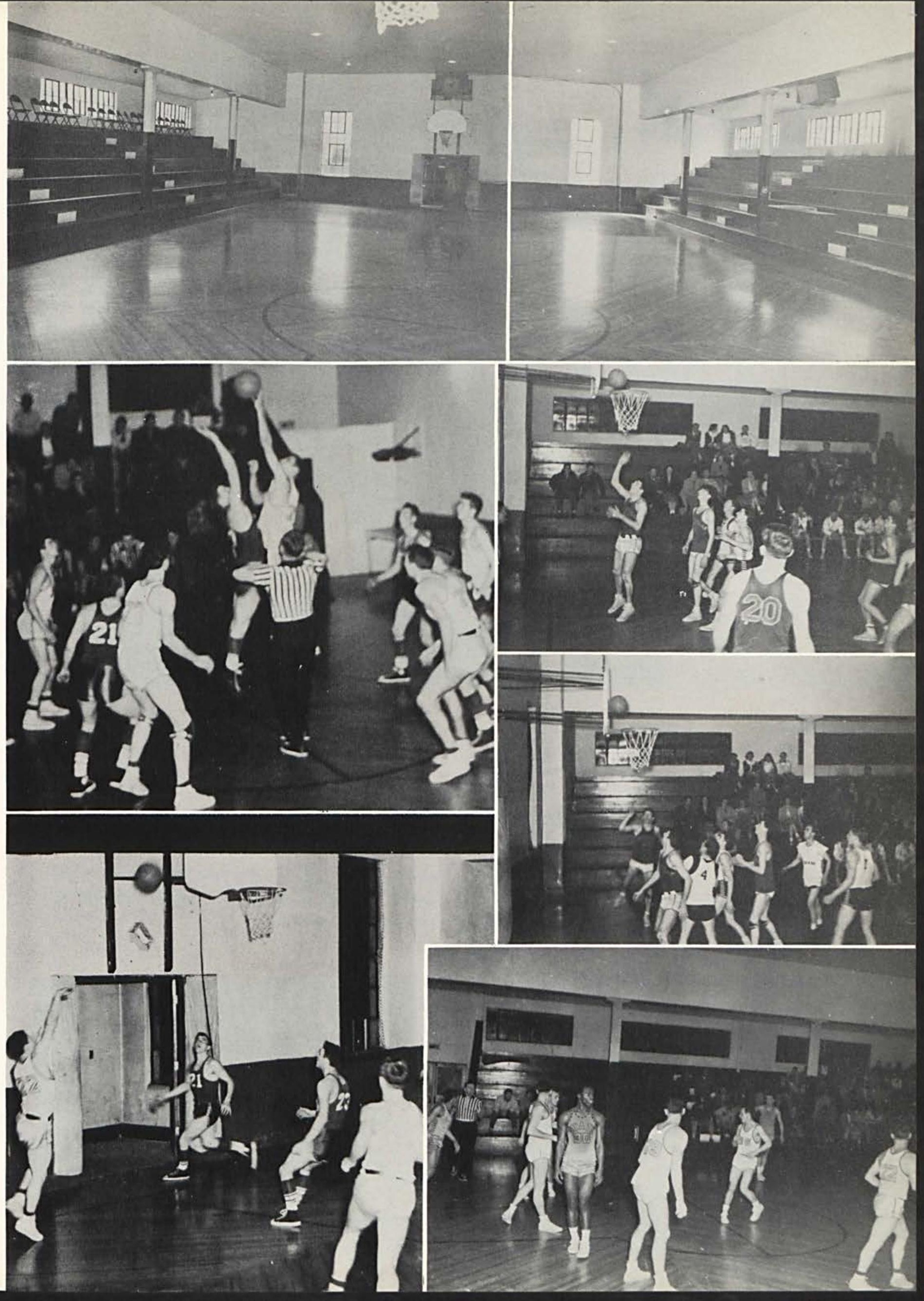




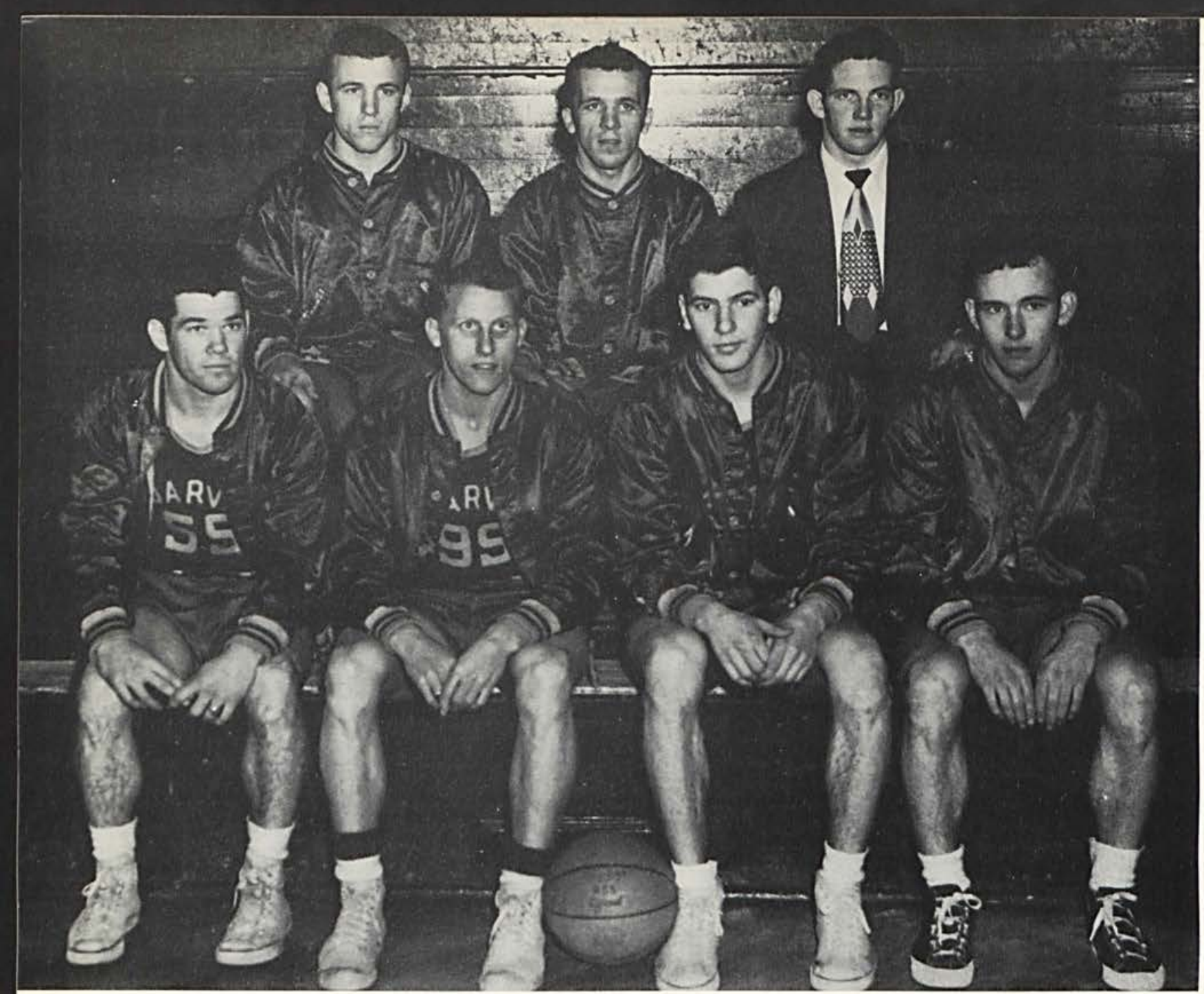

IST ROW: FRENCH, OSBORNE, LAWSON, SMITH. 2ND ROW: CARPENTER, DUNN, COACH EVANS. NOT PICTURED: RUTH, WAGNER, BURR.

\section{Junior Varsity 1950}

The Cedarville College Junior Varsity completed a successful sea son with 10 wins against 7 defeats. Several of the players showed promising ability and may get a call from the Varsity next year, especially Lawson and Smith.
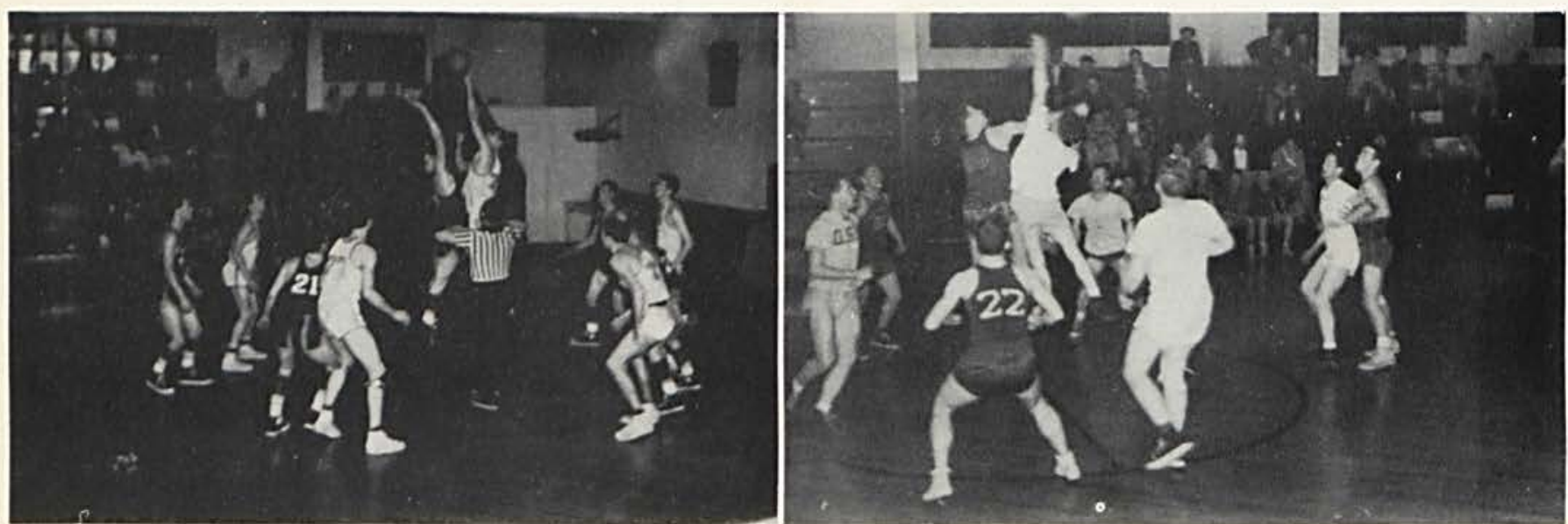


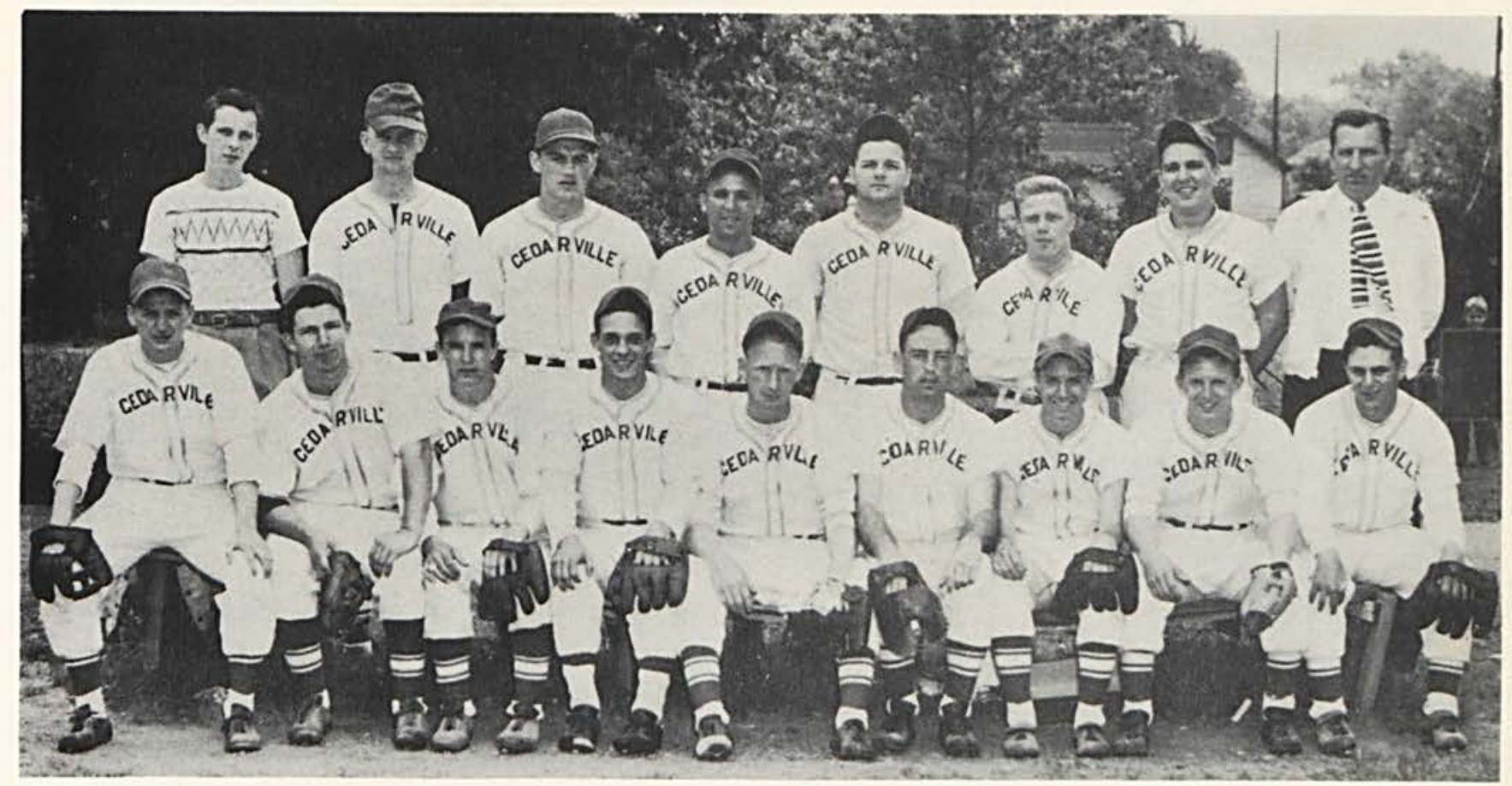

ROW I: DON BARGER, ARCHIE JUSTUS, FLOYD BUTTS, BILL HUFFMAN, LARRY BROOKS, KENNETH HUfFMAN, JIMMY WISECUP, MARCUS TOWNSLEY, AND BILL DUNLAP. ROW 2: BILL PURDOM, BOB RAder, BEN MCNULTY, PAUl DUNn, ROLLIE BARTON, DON NOCK, BOB HILDRETH, AND COACH BEATTIE.

\section{Baseball 1949}

The Cedarville Yellow Jacket Nine had a very tough but successful baseball season. Playing against such teams as Dayton, Xavier, Miami and Morehead they still completed the season with a very impressive record of 8 wins, 5 losses, and 1 tie.

Marcus Townsley and Eugene Judy were the winning pitchers of the season, Townsley taking home six wins and Judy three.
The outstanding game of the season was the 15 inning battle against the University of Dayton in which Judy pitched the last game of his college career. He went all the way only to have game called on account of darkness with the score deadlocked at 2 to 2 .

Playing their last game with the Yellow Jacket nine were Rollie Barton, Don Barger and Eugene Judy.

Don Nock

SEASONAL RECORD

$\begin{array}{lllr}\text { CEDARVILLE } & 3 & \text { MIAMI } & 6 \\ \text { CEDARVILLE } & 0 & \text { MIAMI } & 17 \\ \text { CEDARVILLE } & 6 & \text { WILBERFORCE } & 1 \\ \text { CEDARVILLE } & 5 & \text { MOREHEAD } & 4 \\ \text { CEDARVILLE } & 3 & \text { BLUFFTON } & 6 \\ \text { CEDARVILLE } & 4 & \text { ASHLAND } & 5 \\ \text { CEDARVILLE } & 2 & \text { XAVIER } & 0 \\ \text { CEDARVILLE } & 8 & \text { FINDLAY } & 9 \\ \text { CEDARVILLE } & 5 & \text { ASHLAND } & 4 \\ \text { CEDARVILLE } & 9 & \text { WILBERFORCE } & 6 \\ \text { CEDARVILLE } & 8 & \text { MOREHEAD } & 7 \\ \text { CEDARVILLE } & 11 & \text { WILMINGTON } & 8 \\ \text { CEDARVILLE } & 14 & \text { DAYTON } & 10 \\ \text { CEDARVILLE } & 2 & \text { DAYTON } & 2\end{array}$

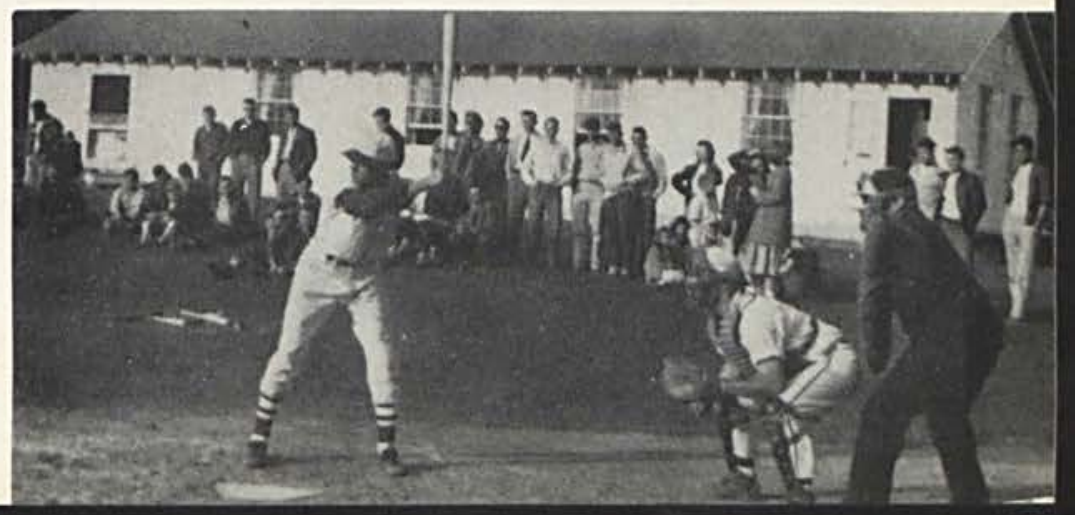




\begin{tabular}{|c|c|c|}
\hline MIAMI & 6 & CEDARVILLE \\
\hline WILBERFORCE STATE & 9 & CEDARVILLE \\
\hline MOOREHEAD & 9 & CEDARVILLE \\
\hline BLUFFTON & 12 & CEDARVILLE \\
\hline DAYTON & 7 & CEDARVILLE \\
\hline FINDLAY & 6 & CEDARVILLE \\
\hline ASHLAND & 19 & CEDARVILLE \\
\hline OHIO NORTHERN & 2 & CEDARVILLE \\
\hline ASHLAND & 6 & CEDARVILLE \\
\hline CHASE & 2 & CEDARVILLE \\
\hline WILMINGTON & 3 & CEDARVILLE \\
\hline BLUFFTON & 4 & CEDARVILLE \\
\hline DAYTON & 0 & CEDARVILLE \\
\hline WILBERFORCE STATE & 11 & CEDARVILLE \\
\hline WILMINGTON & 5 & CEDARVILLE \\
\hline
\end{tabular}

MID OHIO CONFERENCE TOURNEY

\begin{tabular}{lrrrrr} 
ASHLAND & 5 & & \multicolumn{2}{c}{ CEDARVILLE } \\
PITCHERS & GAMES & WON & LOST & PCT. \\
\cline { 2 - 4 } & 4 & & 2 & 1 & .666 \\
WEIMER & 9 & 5 & 4 & .555 \\
TOWNSLEY & 4 & 1 & 1 & .500 \\
EVANS & 3 & 1 & 1 & .500 \\
FIFE & 2 & 0 & 0 & .000 \\
HUNTER & 1 & 0 & 0 & .000 \\
RADER & 1 & & &
\end{tabular}

\section{$T_{\text {rack }}$}

The track team finished fifth in the Mid-Ohio League track meet at Findlay. With the college track under construction and so unusable this year, the interest shown by the team is going to other schools to practice is exemplary of their school spirit.

John Bauman scored six of the Jacket's points with a discus throw of $124 \mathrm{ft}$. $8 \mathrm{in}$. to win first place. Bill Fife, Homer Burton, and Gene Sallee also scored points for Cedarville.

Sutton

Spitzer

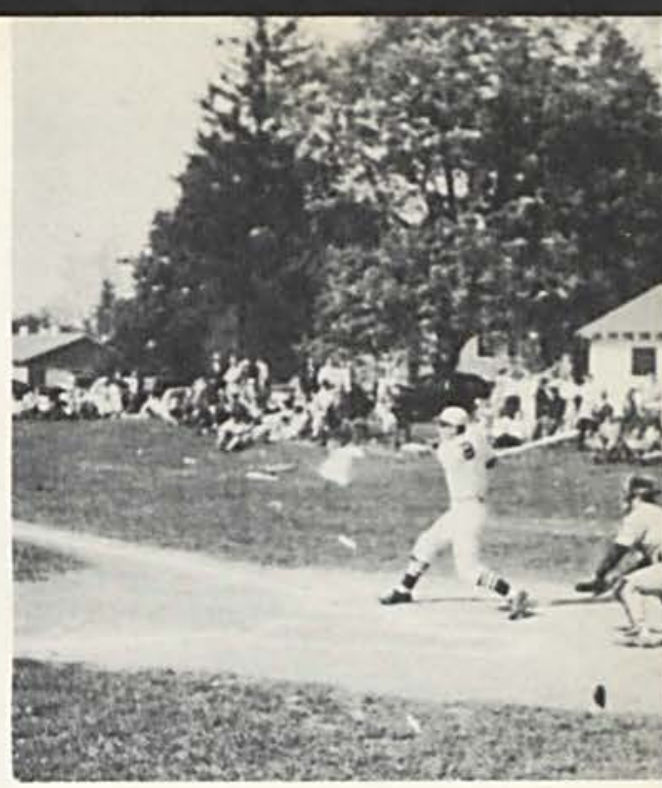

\begin{tabular}{lrr} 
PLAYERS & GAMES & A.B. \\
\cline { 2 - 3 } WETMER & 4 & 9 \\
JUSTICE & 14 & 57 \\
WISECUP & 7 & 18 \\
MCNULTY & 15 & 64 \\
DUNLAP & 15 & 71 \\
HUFFMAN & 16 & 62 \\
FIFE & 3 & 6 \\
ULSH & 16 & 63 \\
SHUMATE & 16 & 62 \\
RADER & 8 & 23 \\
NOCK & 16 & 60 \\
TOWNSLEY & 9 & 30 \\
HILDRETH & 16 & 52 \\
SPICHTY & 5 & 8 \\
EVANS & 4 & 10 \\
COE & 2 & 2 \\
HUNTER & 2 & 2 \\
DUNN & 1 & 0 \\
& TEAM AVERAGE - PCT. 304
\end{tabular}

$\begin{array}{rr}\text { R } & \text { H } \\ 2 & 5 \\ 8 & 23 \\ 5 & 7 \\ 15 & 24 \\ 22 & 26 \\ 15 & 21 \\ 2 & 2 \\ 14 & 19 \\ 13 & 18 \\ 3 & 6 \\ 13 & 14 \\ 7 & 6 \\ 8 & 10 \\ 1 & 1 \\ 2 & 0 \\ 1 & 0 \\ 0 & 0 \\ 1 & 0\end{array}$

Woods
PCT.

.555

.403

.388

.375

.366

.339

.333

.301

.290

.260

.233

.200

.192

.125

.000

.000

.000

.000
Fiedler

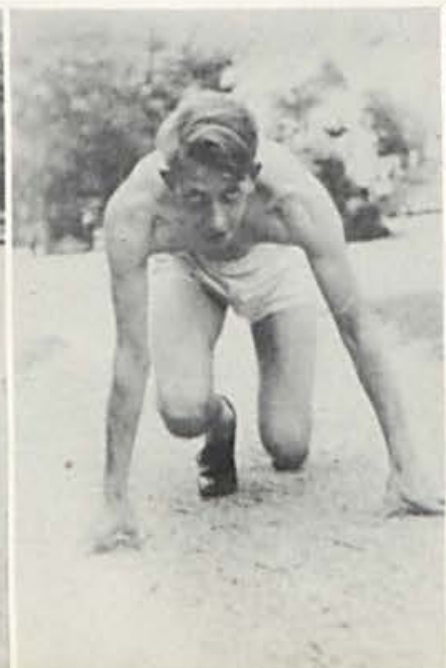

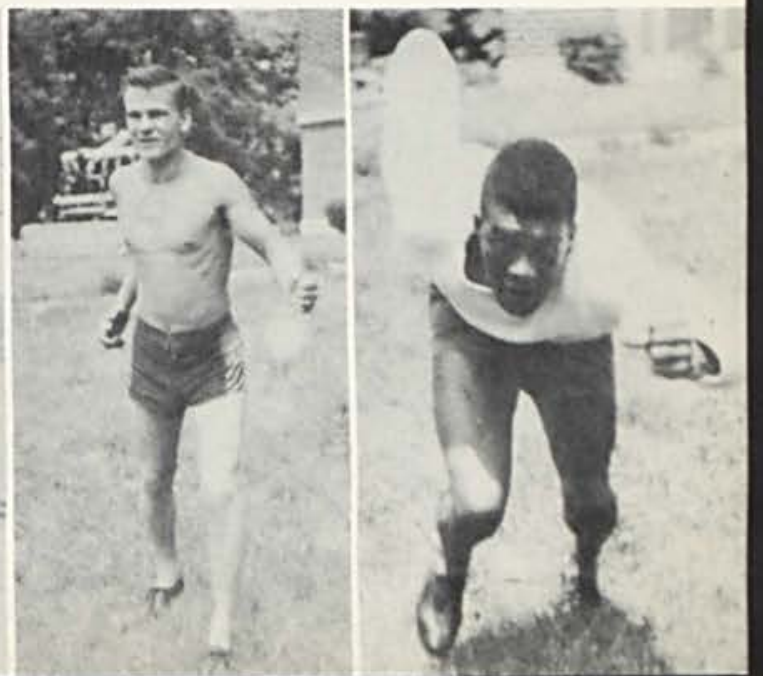




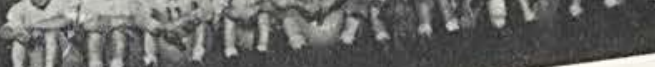

\title{
Football
}

reco Sporting goons

\author{
Basketball
}

113 East High St.

Springfield, Ohio

Baseball

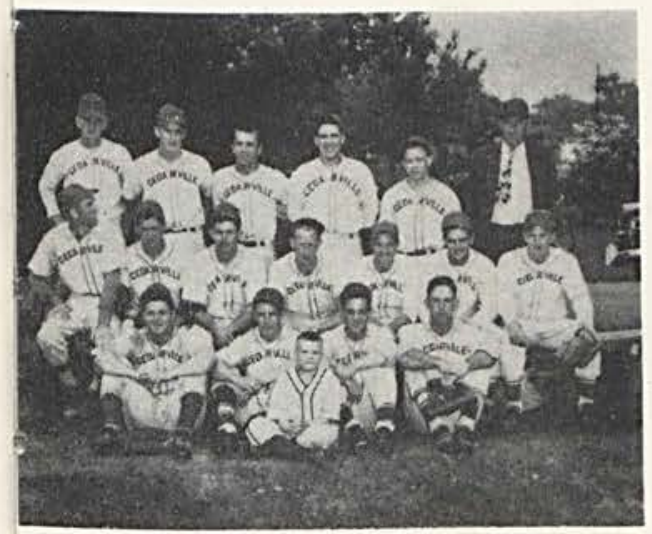

Golf

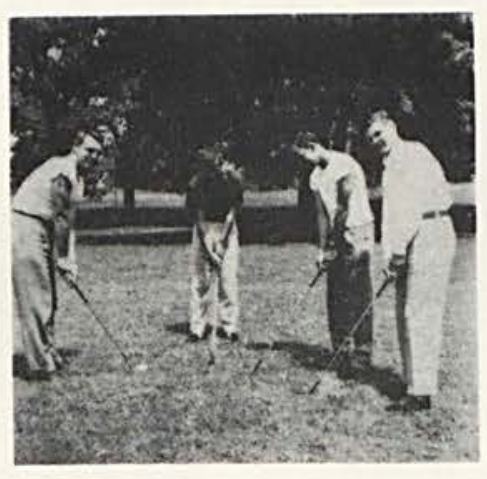

Tennis

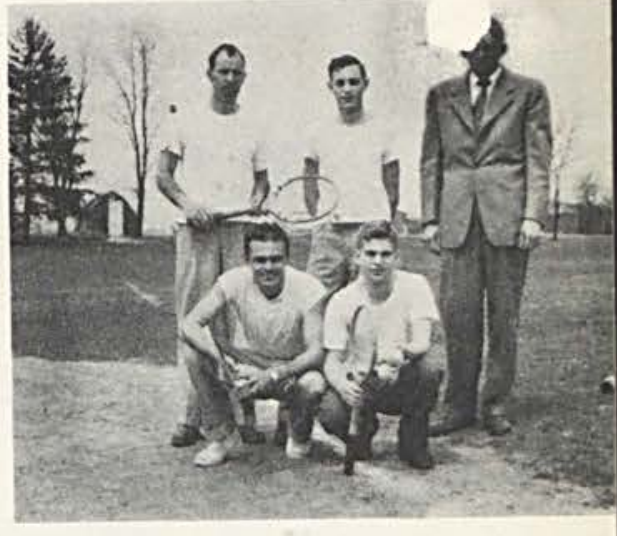

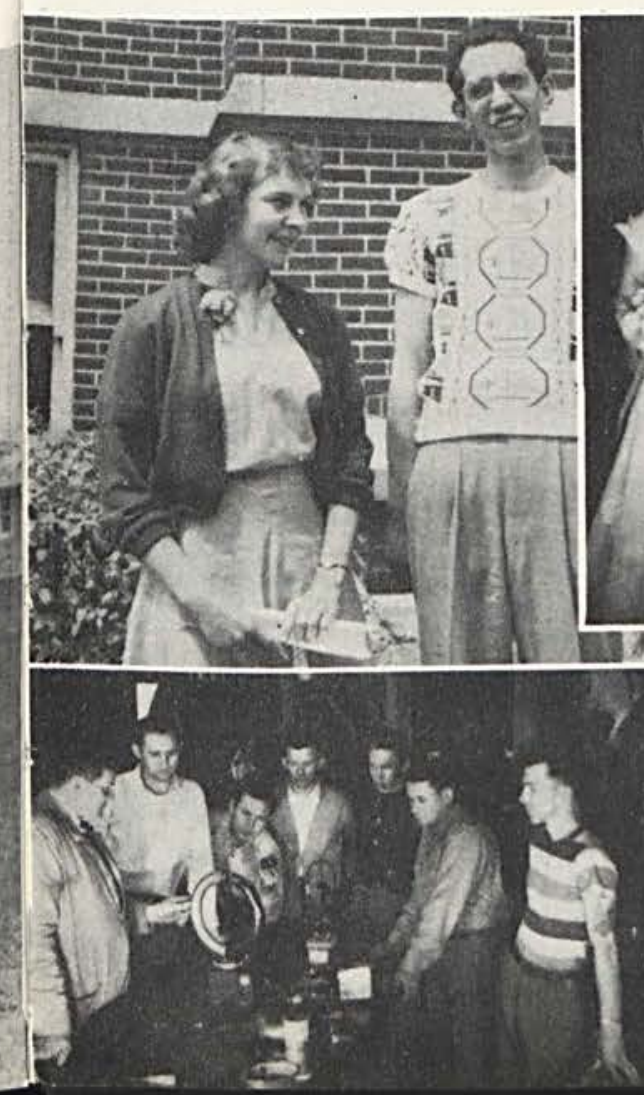
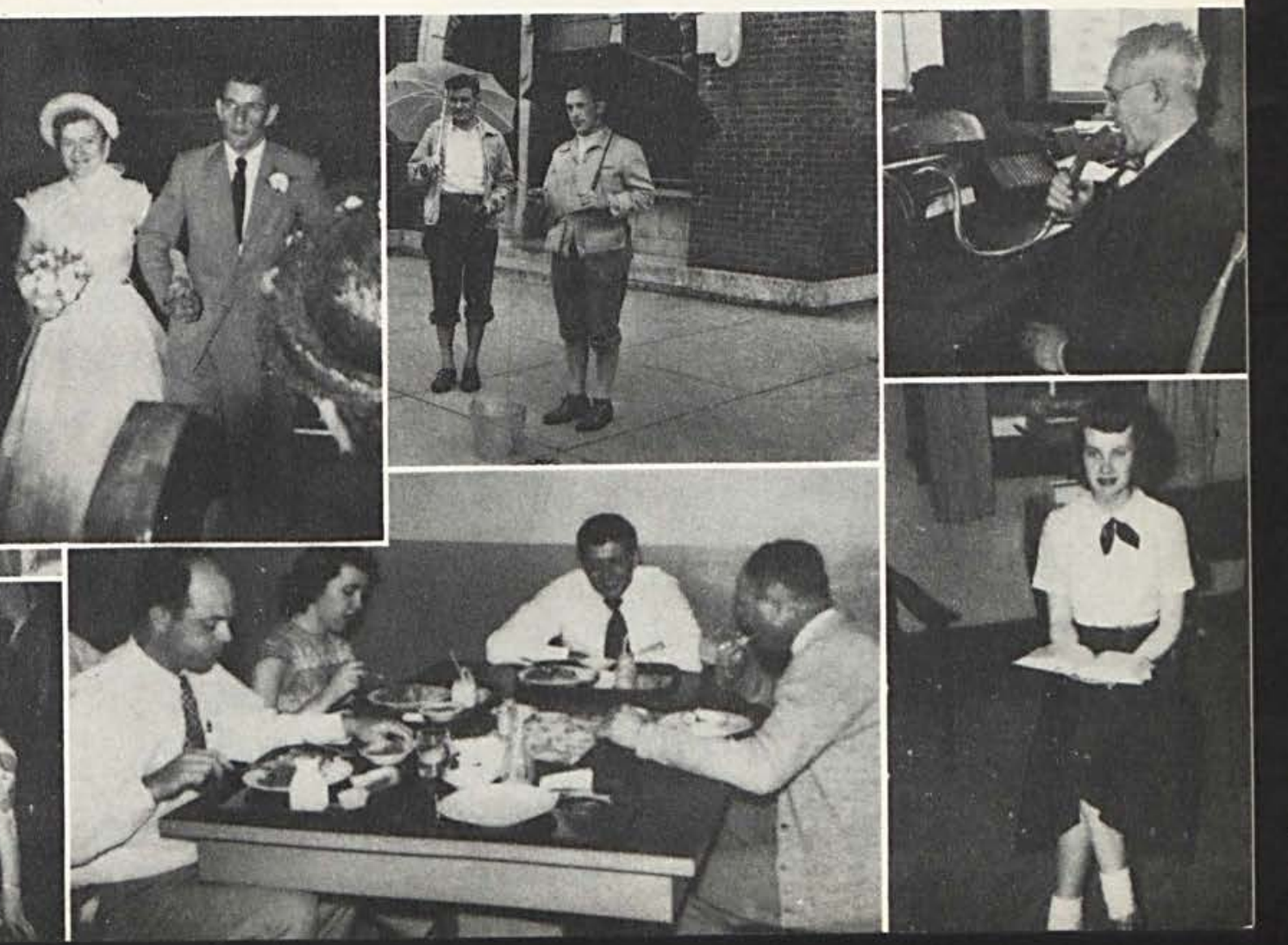


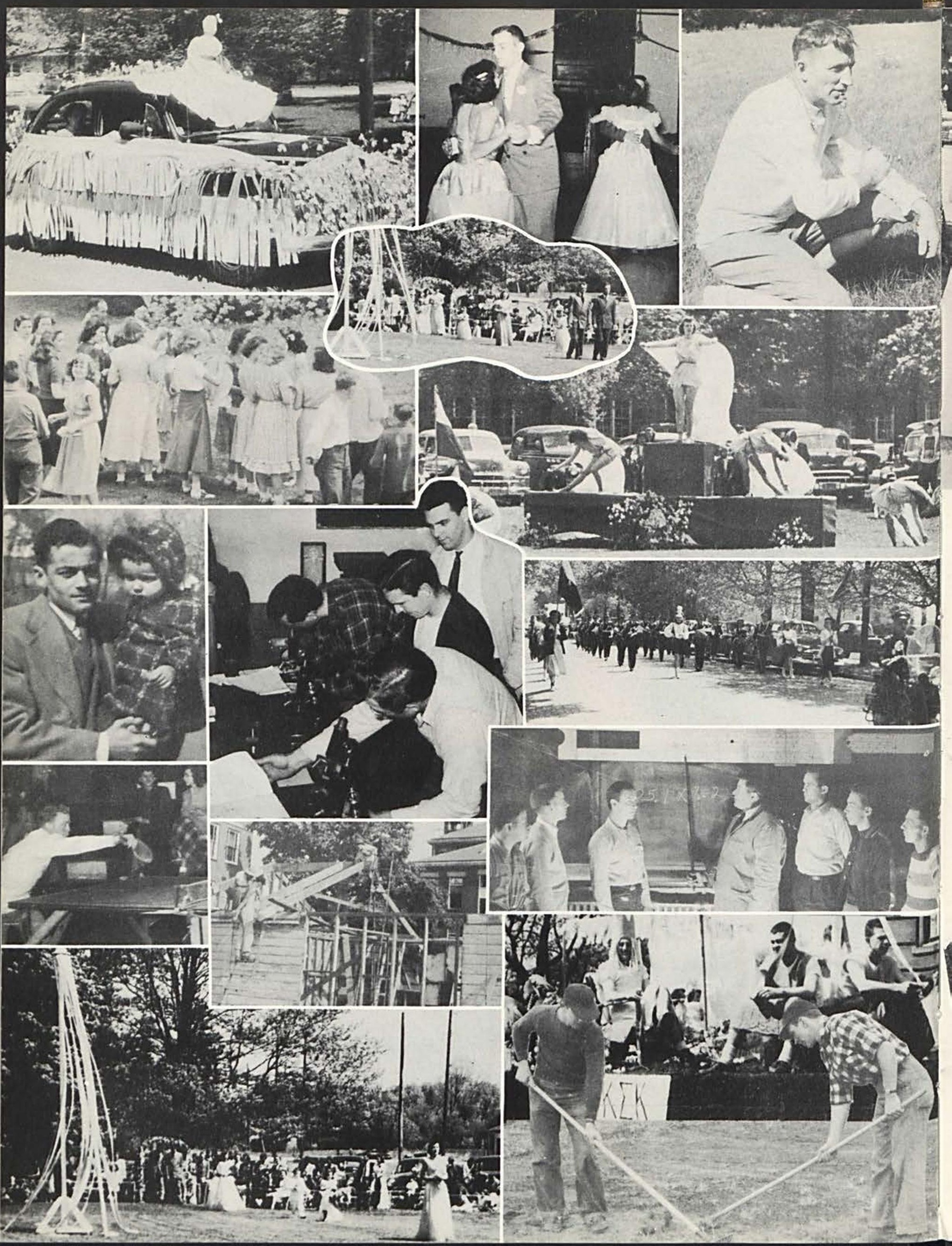




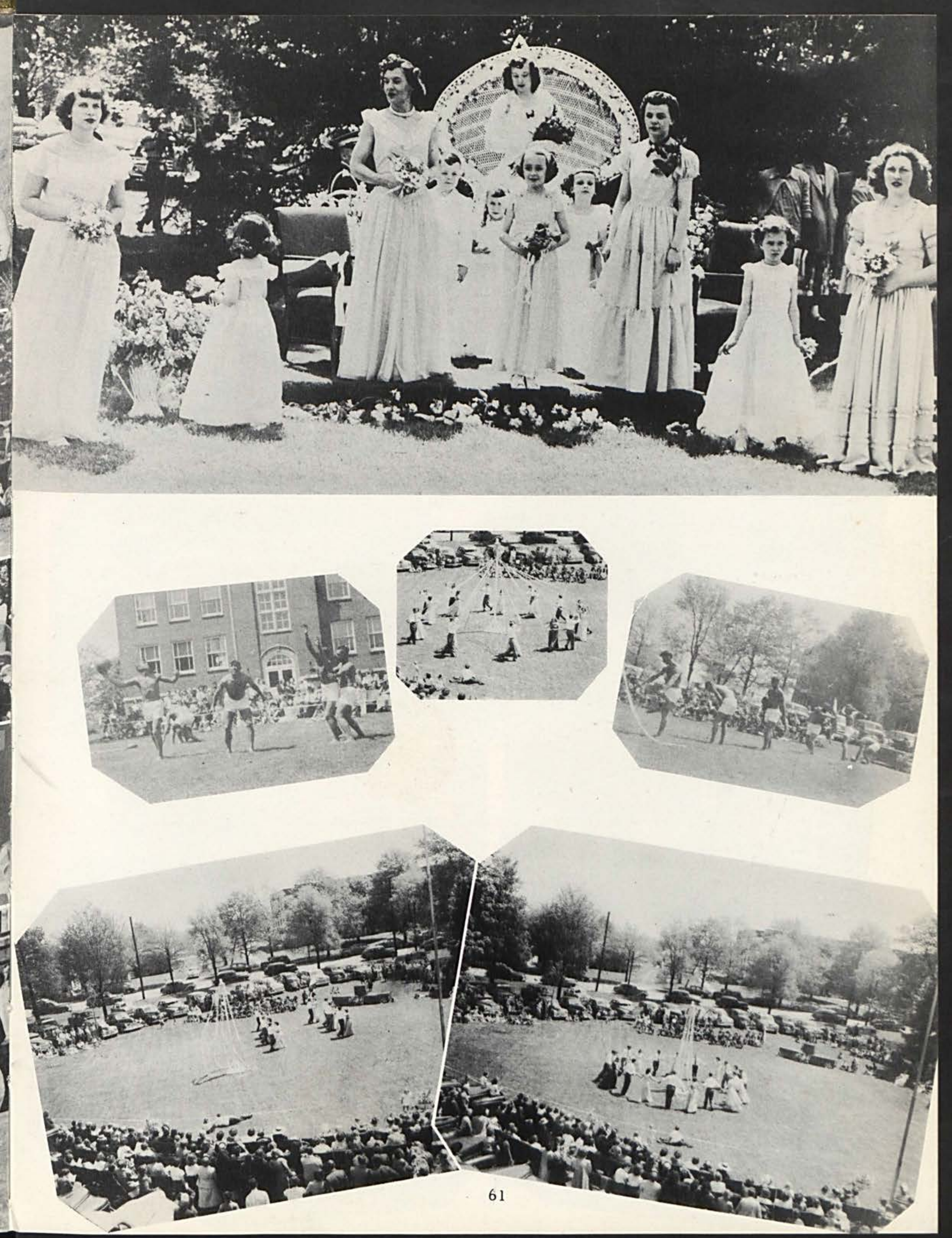




\section{L}

Cedar

Day

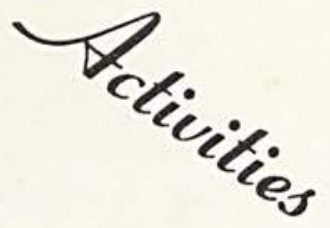

4.

3.

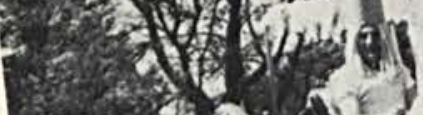

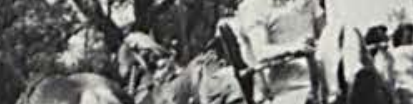

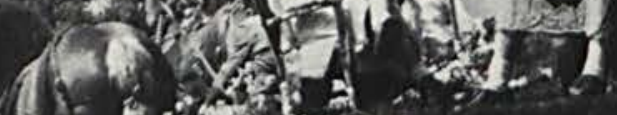

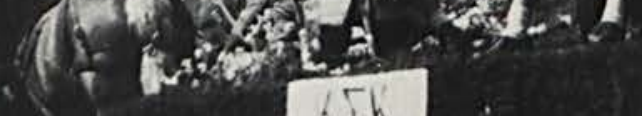

(1)

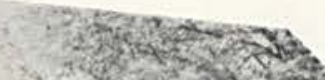

in
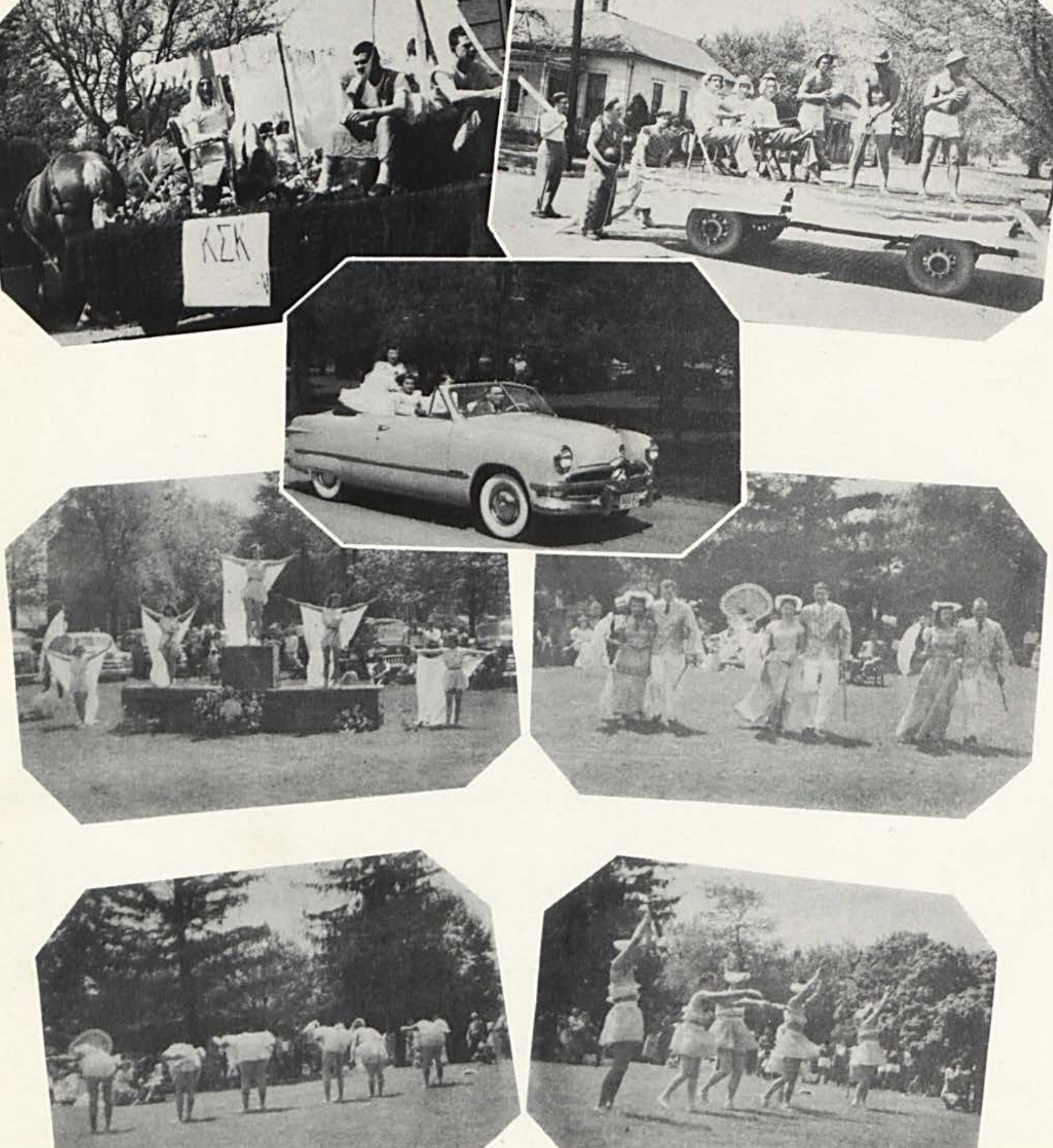


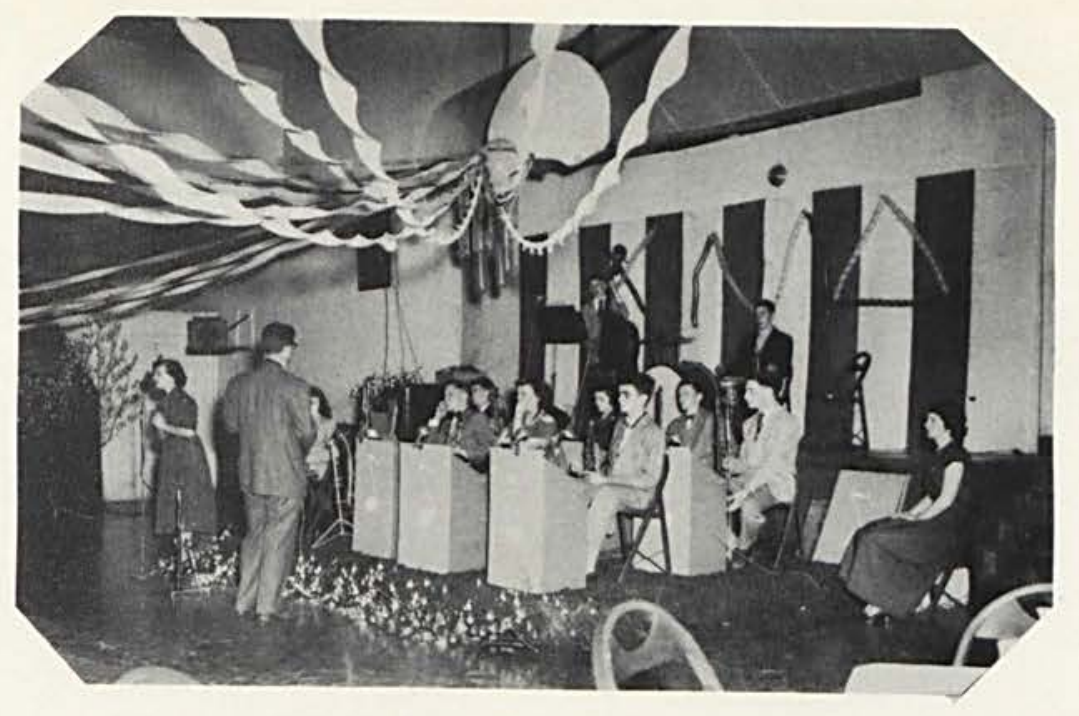

\section{$X M \triangle$}

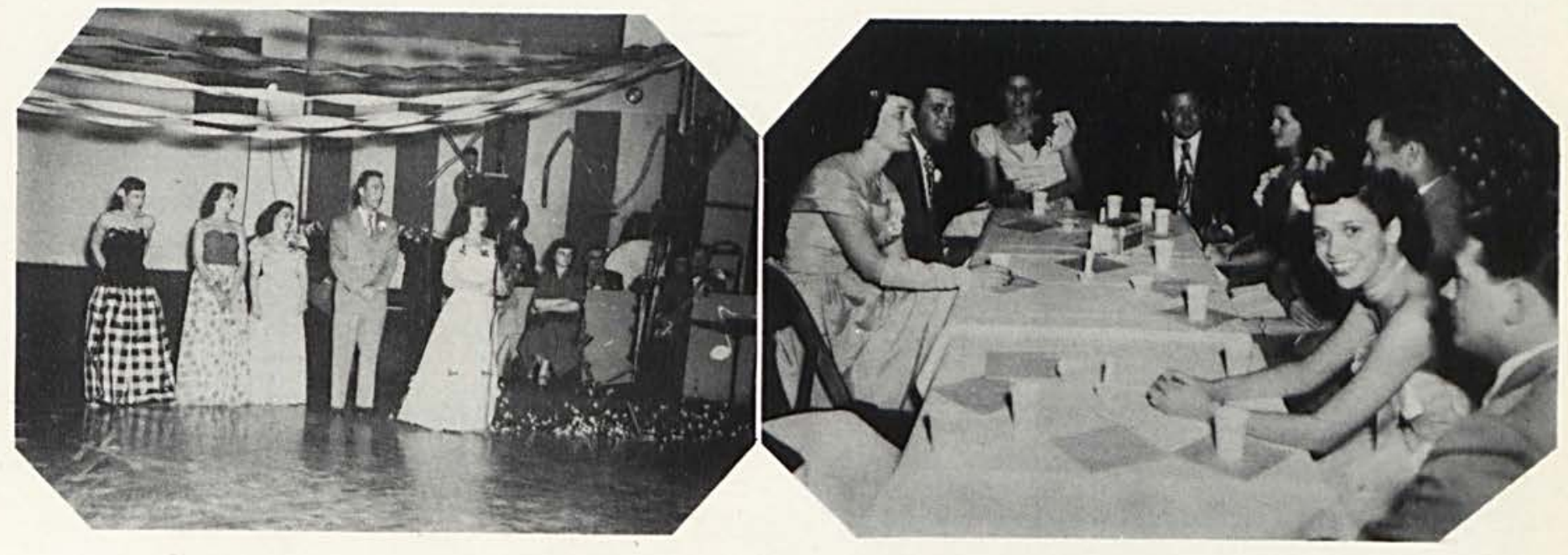

\section{Cedar Day Dance}
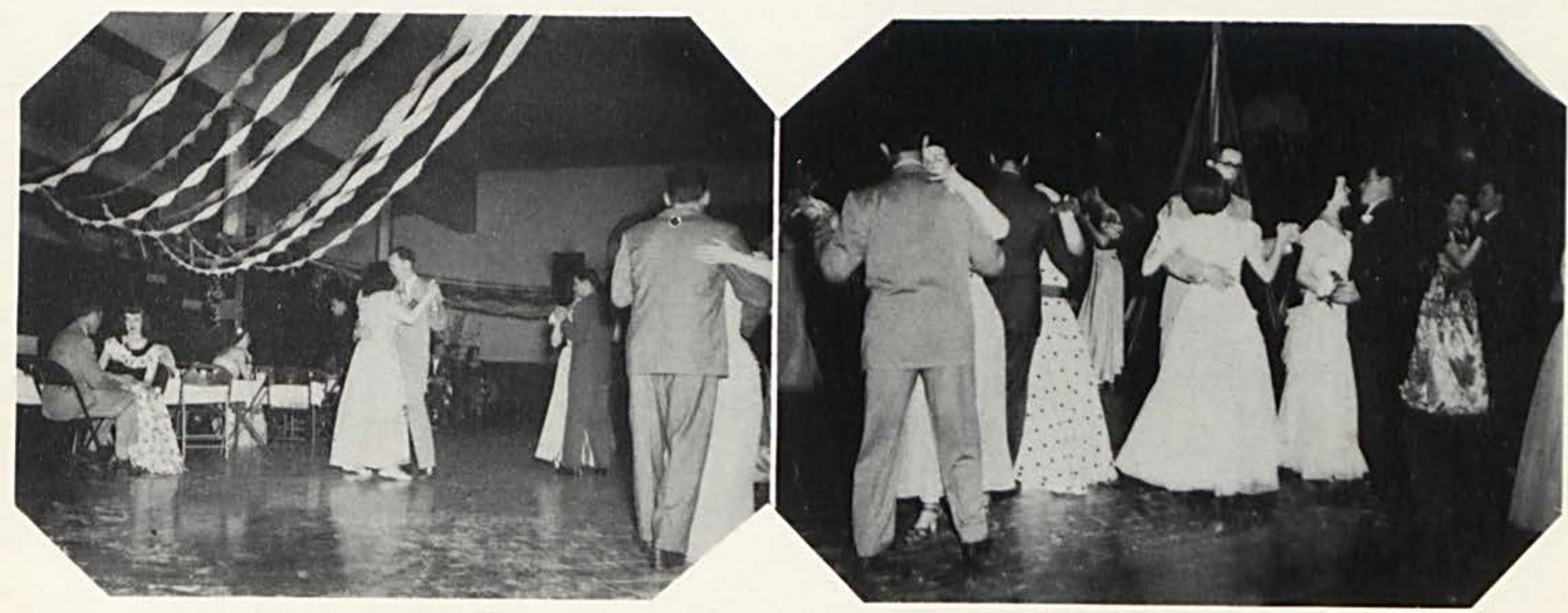


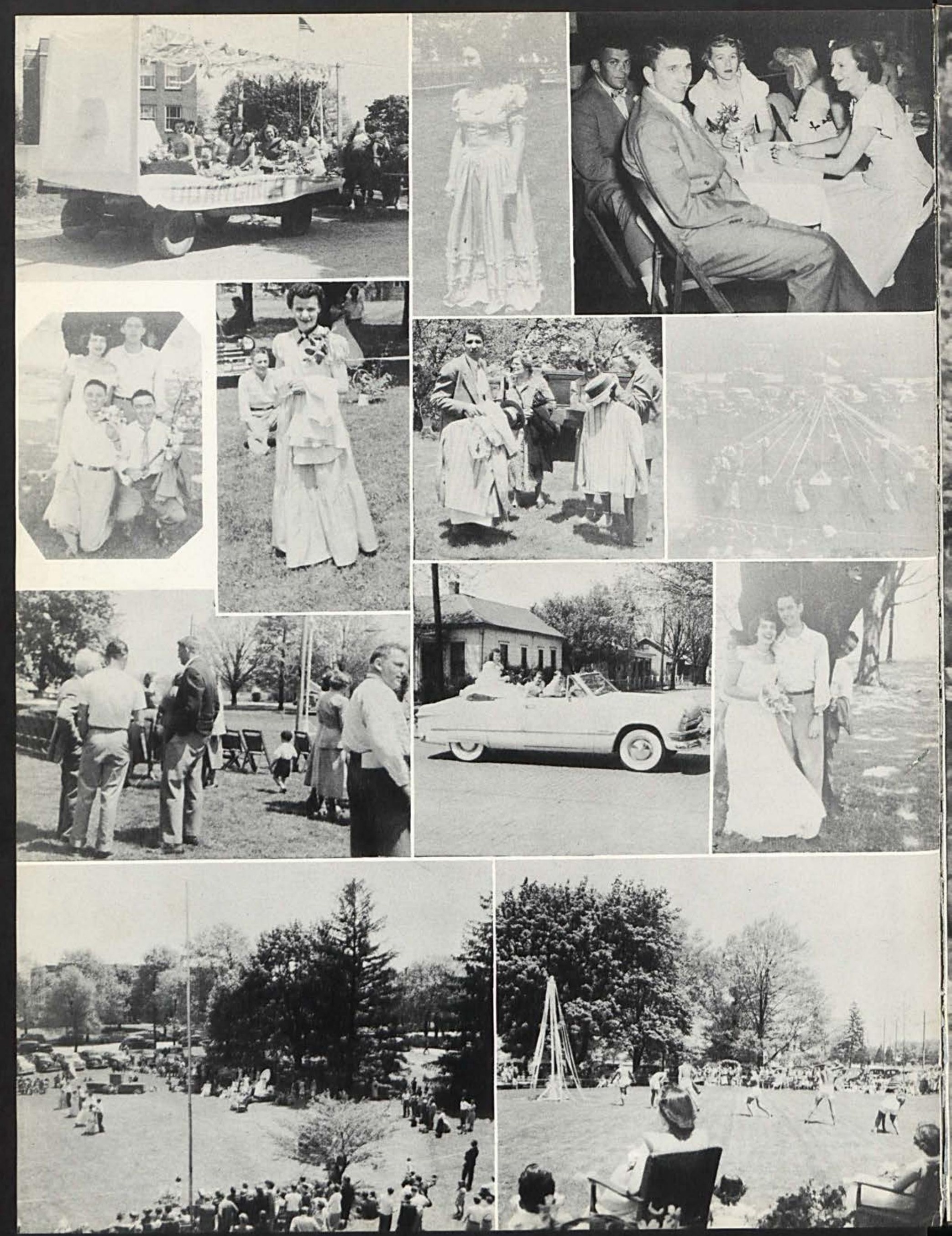




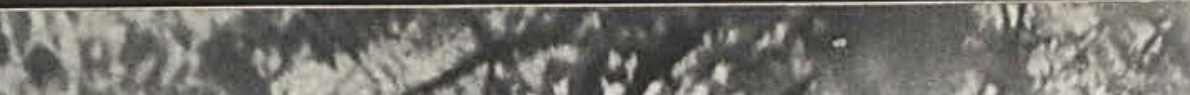

$6 x^{6}+30$ n.

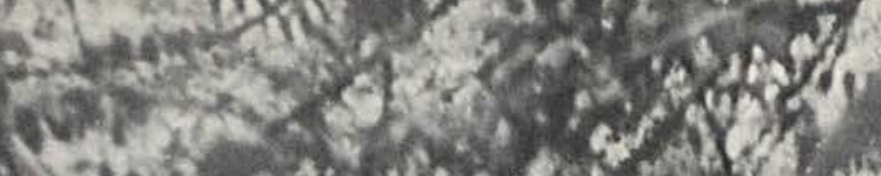

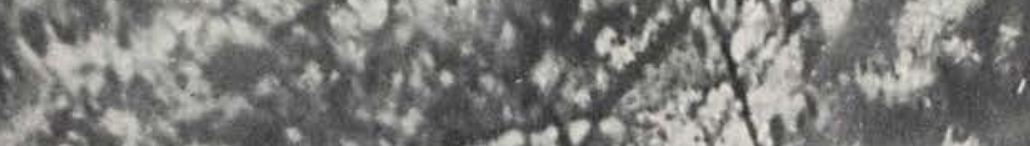

d.t.

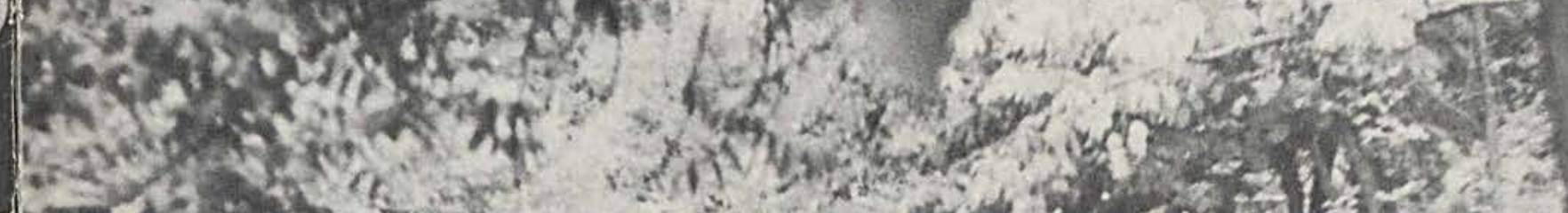

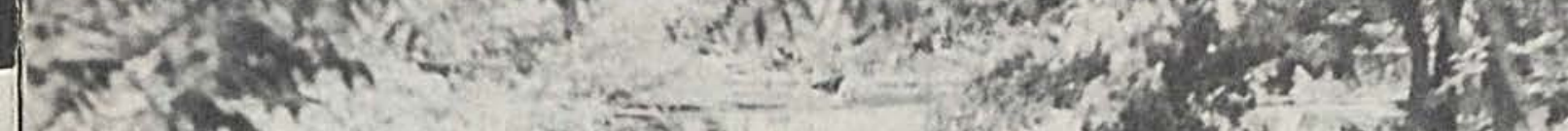

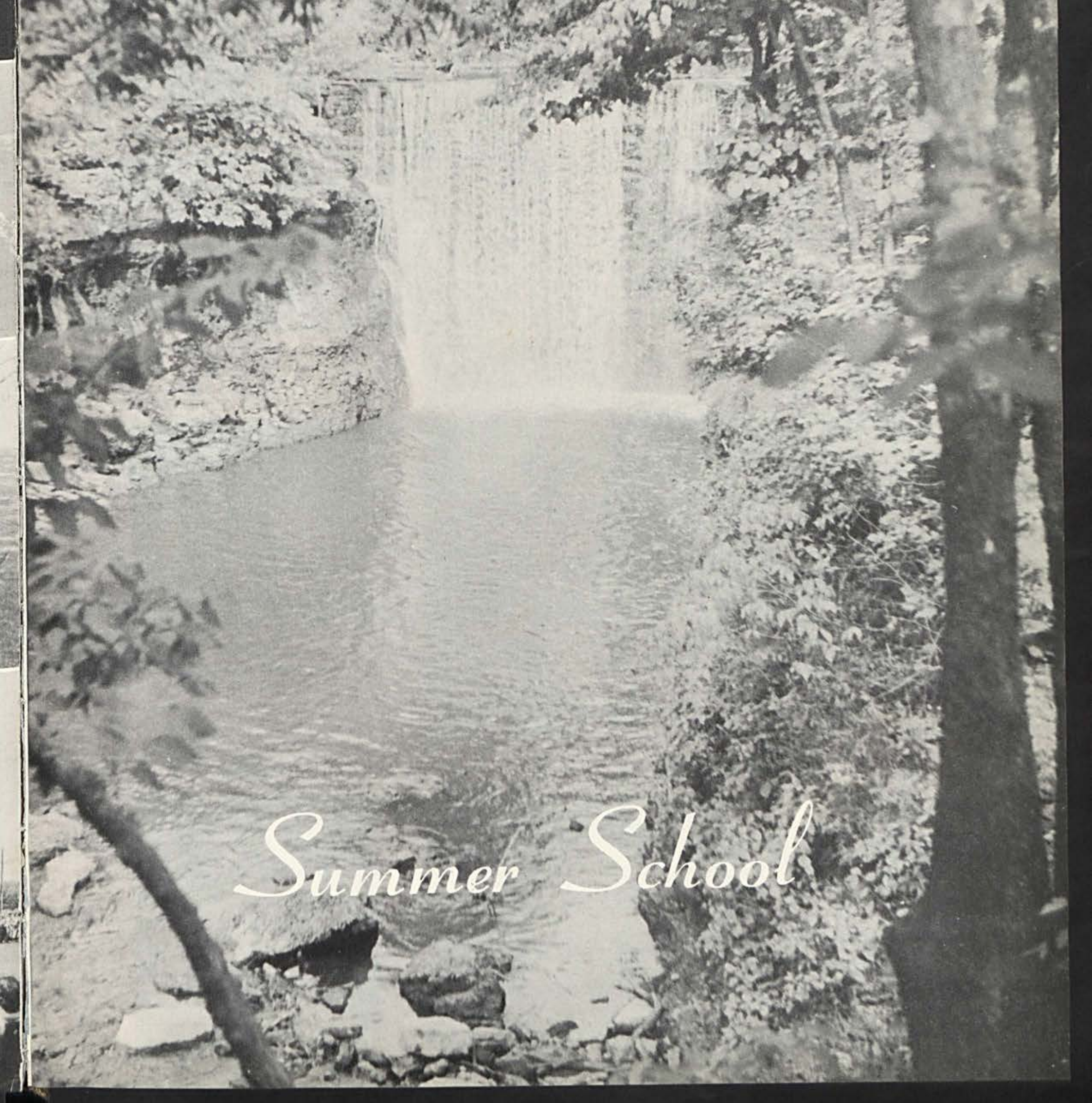




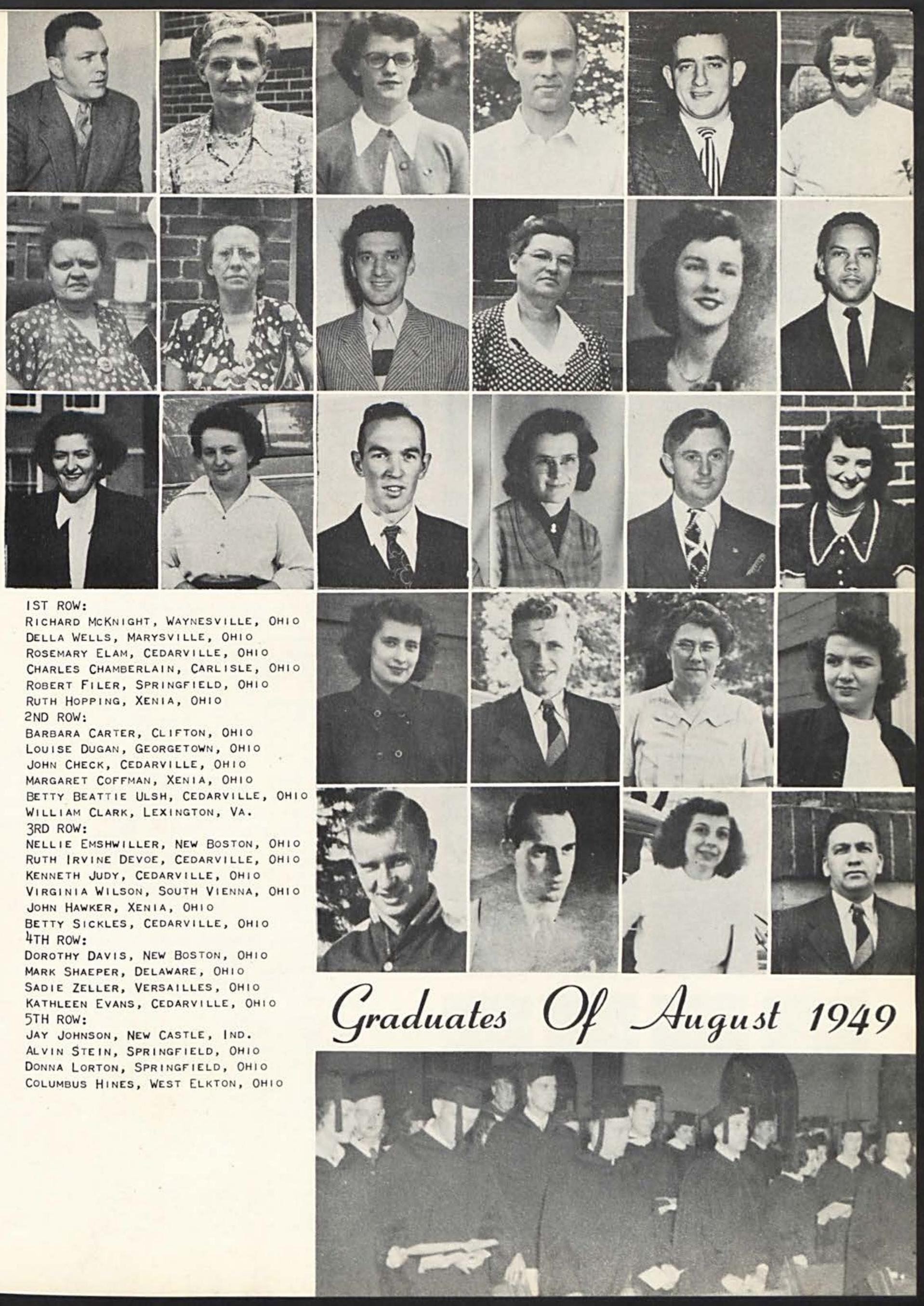



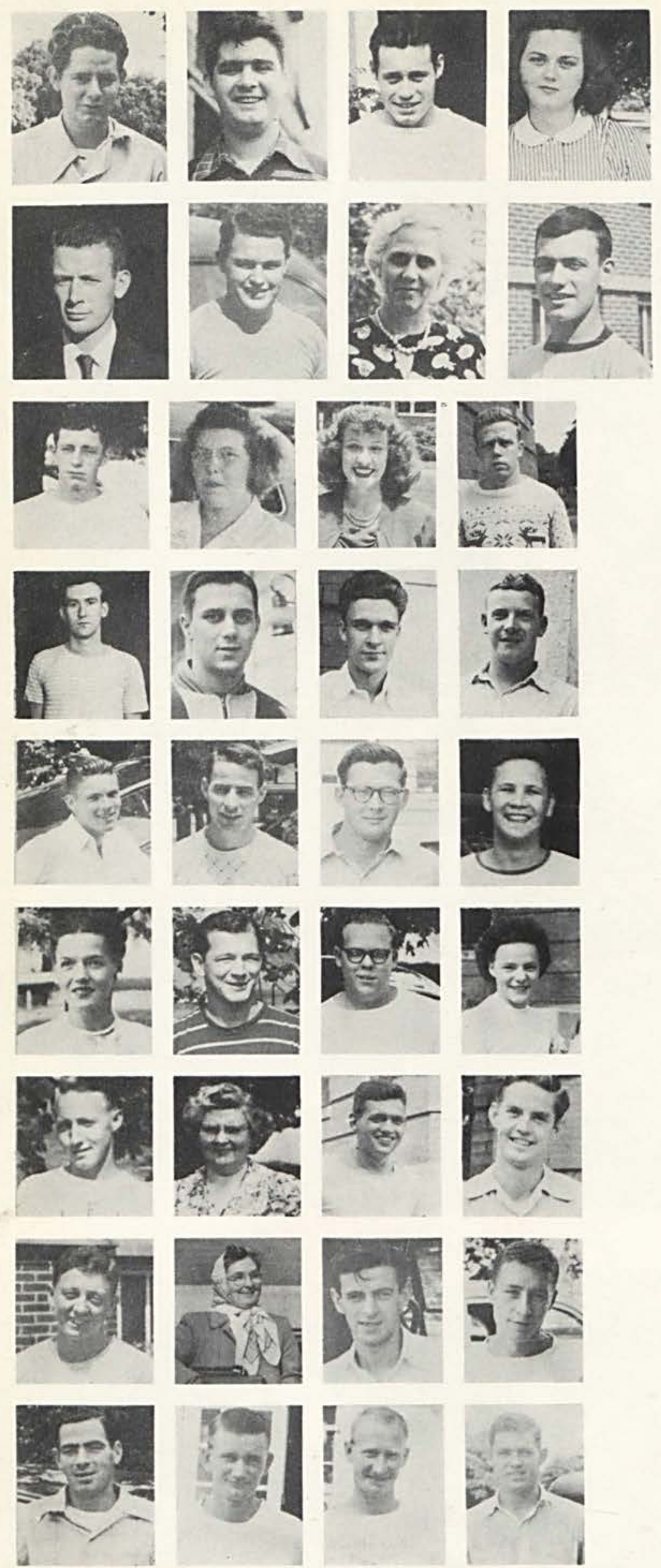
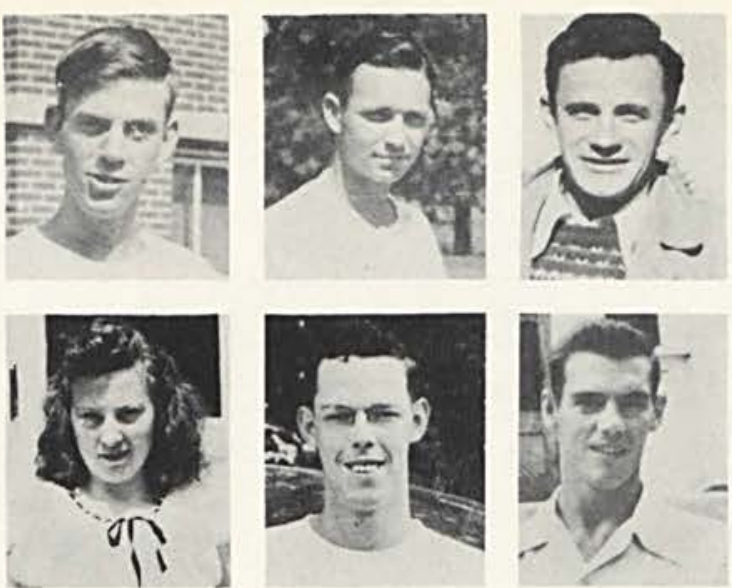

\section{Students}

IST ROW:

JAMES HALEY, SPRINGFIELD, OHIO

RAY MULLENS, SOUTH WEBSTER, OHIO

Eugene Sallee, NEW BURLINGTON, OHIO

PATRICIA GRIEVE, XENIA, OHIO

BILL FIFE, CEDARVILLE, OHIO

BILL CUNNINGHAM, PORTSMOUTH, OHIO

Ray Gentile, Cleveland, OHIO

2ND ROW:

BILL OSMAN, CEDARVILLE, OHIO

GERALD BRADFORD, SPRINGFIELD, OHIO

RUTH KELNER, VERSAILLES, OHIO

TED SUTTON, WEIRTON, W. VA.

VIOLA THURMAN, ENGLEWOOD, OHIO

ROGER ULSH, SPRINGFIELD, OHIO

ERNEST STANLEY, SCIOTOVILLE, OHIO 3RD ROW:

NORMAN HOWARD, SOUTH WEBSTER, OHIO JOANNA BRYANT, CEDARVILLE, OHIO

MILDRED HORNER, SOUTH WEBSTER, OHIO DON NOCK, DAYTON, OHIO

4TH ROW:

RICHARD EVANS. HAMILTON, OHIO

BILL DUNLAP, HAMILTON, OHIO

Dave sisson, Cleves, OHIO

WENDELL CULTICE, CEDARVILLE, OHIO 5TH ROW:

RAY THOMPSON, SCIOTOVILLE, OHIO

ART LEWIS, SOUTH WEBSTER, OHIO JAMES HAUCK, SPRINGFIELD, OHIO

JOHN STEWART, CEDARVILLE, OHIO

6TH ROW:

LIVIA CHECK, CEDARVILLE, OHIO

WALT SEWAK, JOHNSTOWN, PA.

ELDON MATHEWS, SPRINGFIELD, OHIO

NAOMI CONNER, CEDARVILLE, OHIO

7TH ROW:

Clell Murphy, SOUth Webster, OHIO

MARY HANNA, CEDARVILLE, OHIO

KENNY WILBURN, CEDARVILLE, OHIO

STANLEY SCOTT, MINFORD, OHIO

8TH ROW:

HUCK WARIX, SUPERIOR, OHIO

PAULINE POWERS, CEDARVILLE, OHIO

DICK WRIGHT, CEDARVILLE, OHIO

RICHARD SMITH, XENIA, OHIO

9TH ROW:

JAMES BURNS, PORTSMOUTH, OHIO

BOB RADER, MANCHESTER, OHIO

LARRY BROOKS, DAYTON, OHIO

EDDIE SOWELL, XENIA, OHIO 

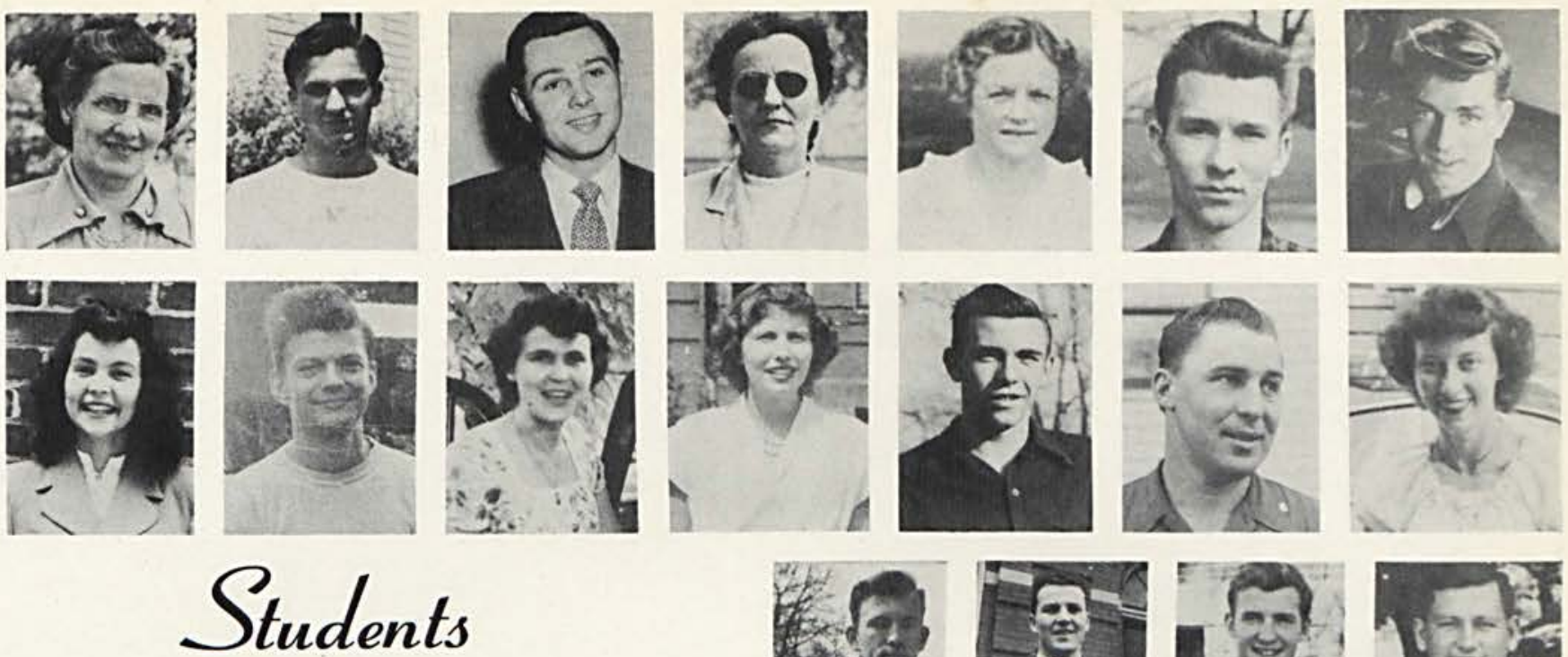

IST ROW:

TREVA SHERER, VERSAILES, OHIO WALTER HRKMAN, JOHNSTOWN, PA. DAN WEBSTER, HAMILTON, OHIO GLADYCE BARRY, XENIA, OHIO RUTH NEATHERTON, XENIA, OHIO TOM BELLVILLE, EAST FULTONHAM, OHIO JIM WISECUP, CEDARVILLE, OHIO 2ND ROW:

VIVIAN POTTS, SOUTH WEBSTER, OHIO EMORY BEIREIS, CEDARVILLE, OHIO FLORENCE BARKALOW, XENIA, OHIO PHYLLIS BRYANT, CEDARVILLE, OHIO DOUgLas CULTICE, CEDARVILLE, OHIO JOHN BLAZER, CEDARVILLE, OHIO ELEANOR WEISMILLER, SELMA, OHIO 3RD ROW:

MARTIN WEIMER, JR. CEDARVILLE, OHIO CHARLES DAVIS, BAINBRIDGE, OHIO JIM SHAFFER, MINERVA, OHIO DON GEIS, JAMESTOWN, OHIO 4TH ROW:

HENRY BEATTIE, CEDARVILLE, OHIO MAX BITLER, ROSEWOOD, OHIO BEN MCNULTY, MANCHESTER, OHIO EMERSON ACKISON, XENIA, OHIO 5TH ROW:

MYERS BOST, SPRINGFIELD, OHIO HARMON LUM, HAMILTON, OHIO CARL MURNAHAN, IRONTON, OHIO VERA MURNAHAM, IRONTON, OHIO 6TH ROW:

BILL PURdom, CEDARVILLE, OHIO FLOYD GOTHARD, SPRINGFIELD, OHIO JoANNA SANDERSON, CLIFTON, OHIO MARIE FISHER, CLAYTON, OHIO 7TH ROW:

ROBERT IMPSON, SPRINGFIELD, OHIO TOM OSBORNE, SOUTH POINT, OHIO WALT BLATERIC, AKRON, OHIO BION BRADBURY, CEDARVILLE, OHIO 8TH ROW:

JAMES DUNN, WINCHESTER, OHIO BILL HAMMOND, SCIOTVILLE, OHIO LILLIE FINLAY, XENIA, OHIO JACK CANADAY, GALLIPOLIS, OHIO 9TH ROW:

LORNA CRAIGIE, XENIA, OHIO WINDY LEWIS, SOUTH WEBSTER, OHIO Clay CotTle, SCIOTOVILLE, OHIO JaCK BELLVILLE, EAST FULTONHAM, OHIO
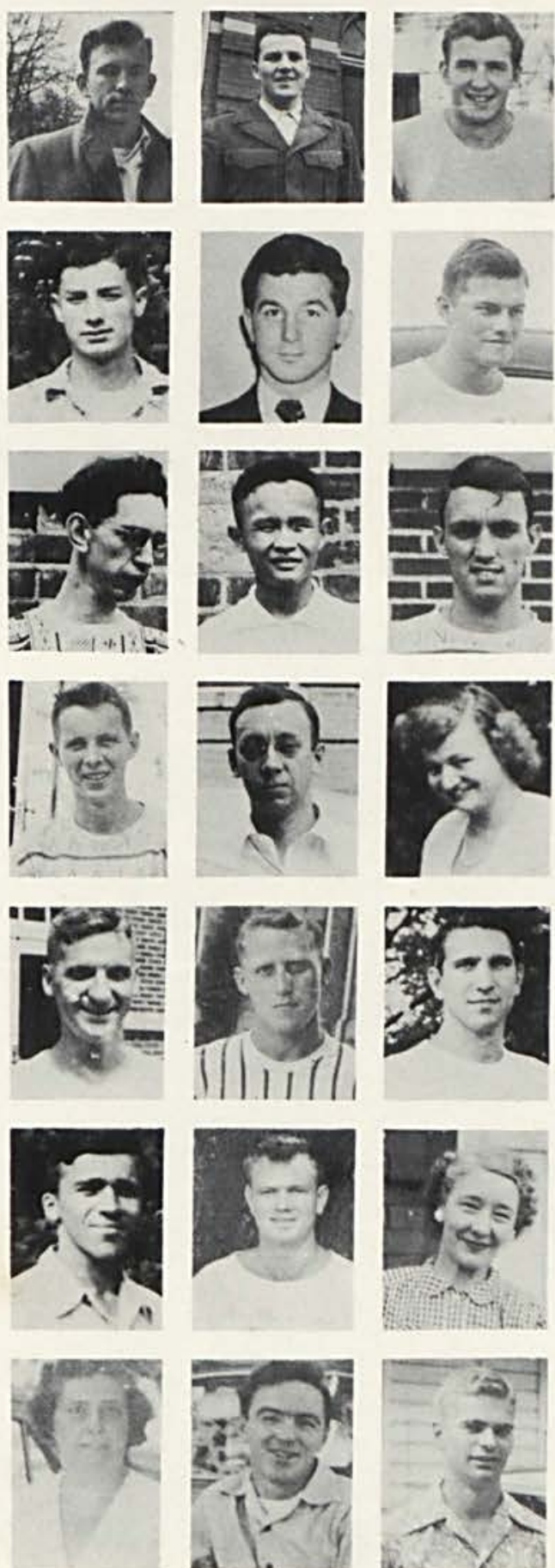
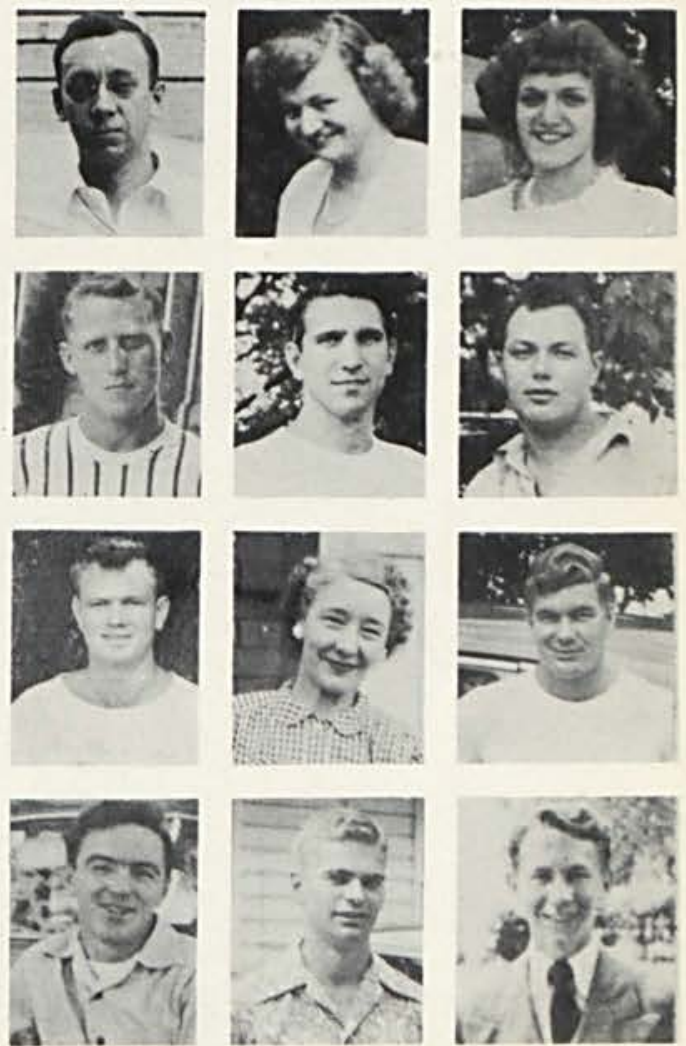


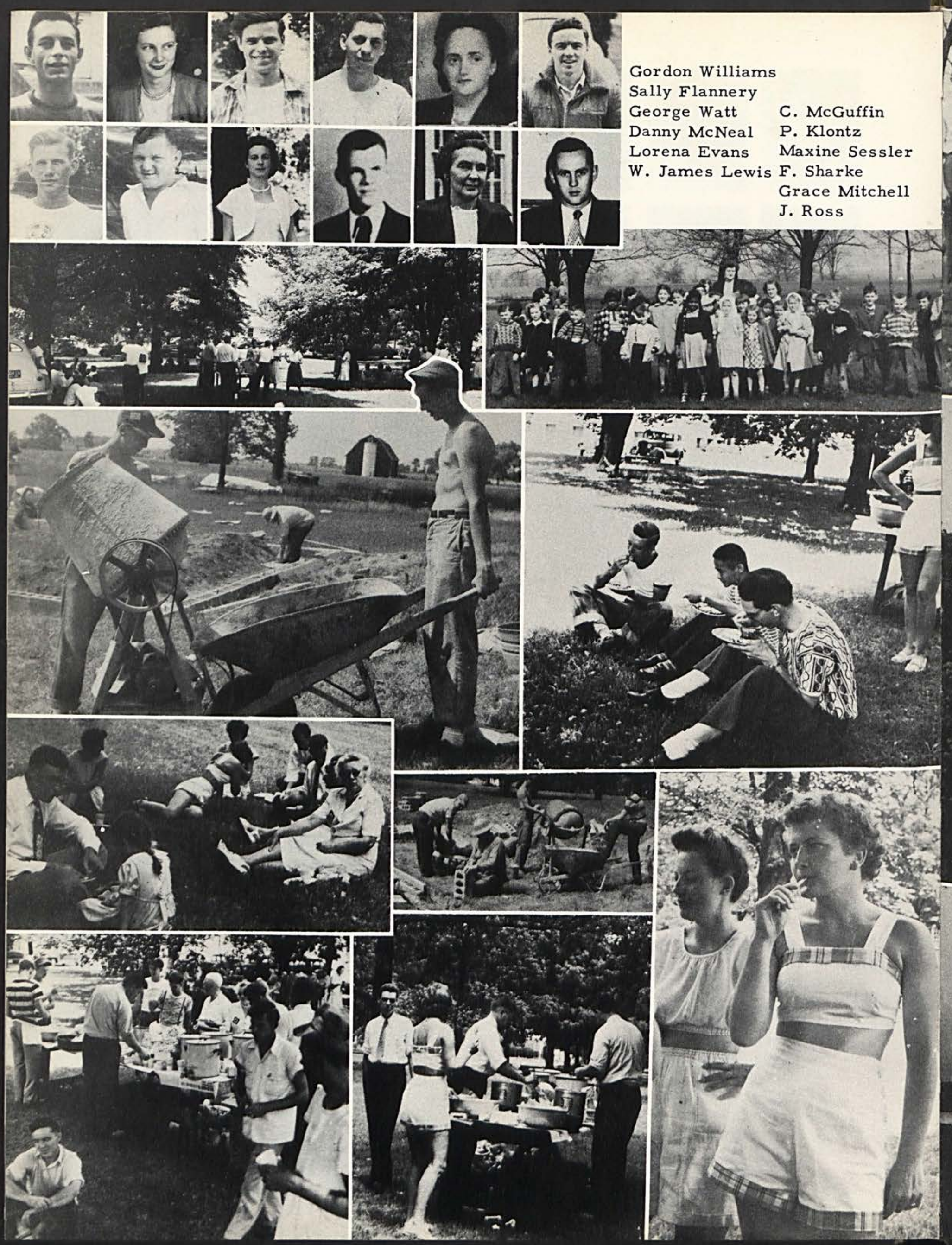


$\mathrm{H} U \mathrm{D} \mathrm{SON}$

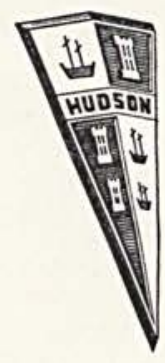

America's Safest Car

LAWRENCE MOTORS, INC

Phone 5-1566

123 N. Spring St.

Springfield

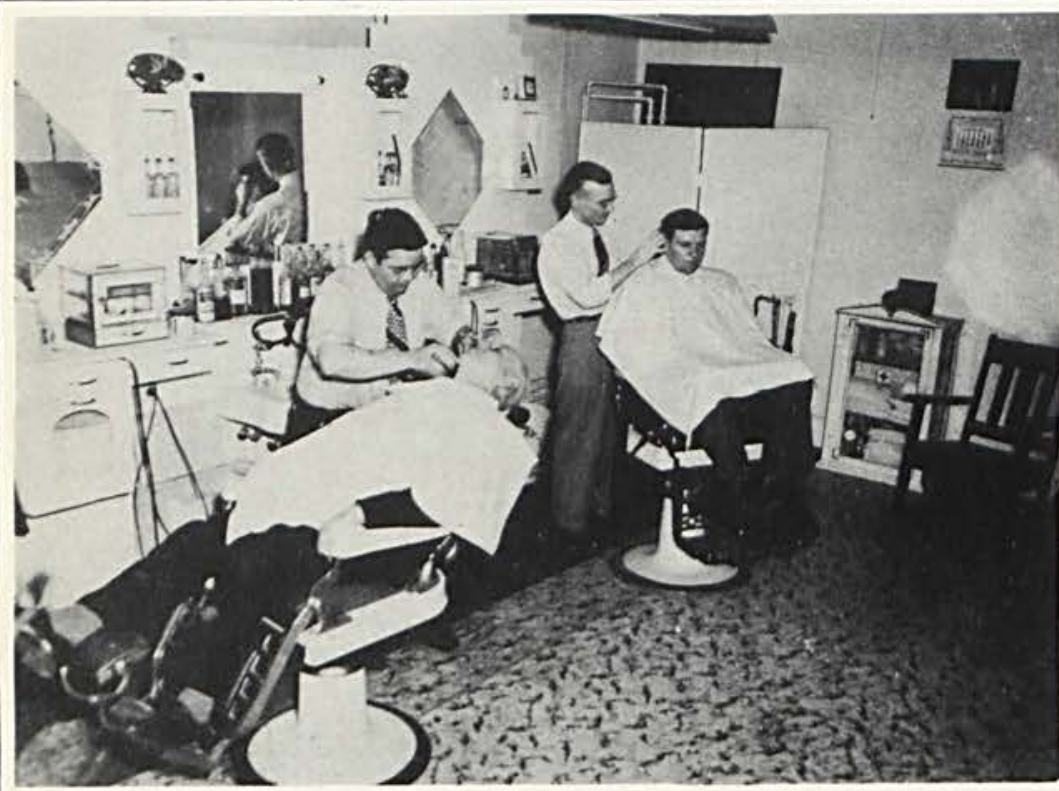

WOOD'S BARBER SHOP

N. Main St.

Cedarville, Ohio

The College Favorite

J. R. Woods, Propr.

BIRD VARIETY STORE

Cedarville, Ohio

Wallpaper

Infants' Wear

Stationery

"The Friendly Place to Shop"
XENIA SCHOOL AND

OFFICE SUPPLY STORE

35 Greene Street Xenia, Ohio

W. E. Boring, Prop. 


\section{LAПG'S}

Sale And Service

Used Cars And Trucks

Phone No. 872

Xenia, Ohio

\section{VALENTINE}

Shoe Repair, Hat Cleaning and Shining Parlor

All Work Guaranteed

Phone 4-1297

10 North Fountain Springfield

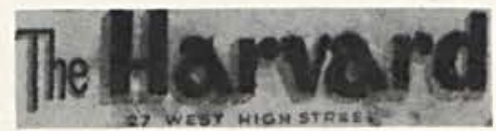

"TRULY A GREAT STORE FOR MEN"

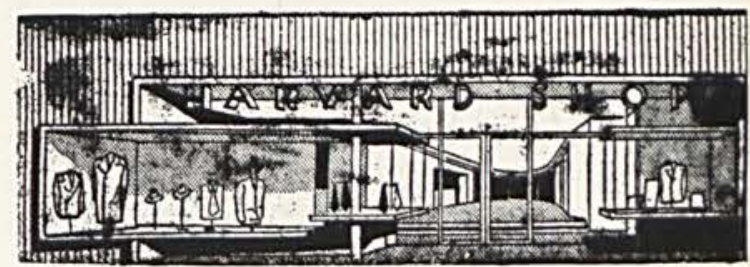

Compliments of

THE CEDARVILLE LOCKER

D. H. Reynolds

Cedarville, Ohio
Cameras

Movie Equipment

Photographic Supplies

RAPID PHOTO SERVICE, INC.

45 West High Street Springfield, Ohio 


\section{Borden's}

Milk

Butter

Cheese

In Cedarville, visit

CONFARR'S PANTRY

IF IT S BORDEN S

IT'S GOT TO BE GOOD!

Springfield, Ohio

Phone 3-9711

REFRESHMENT UV: CUNAT CENTEF

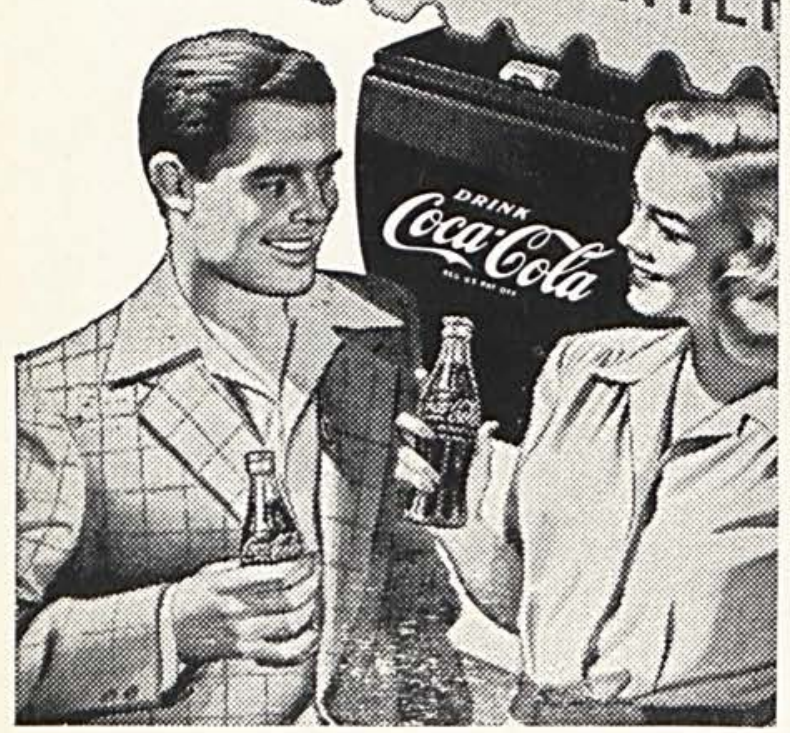

BomLd UNDER AUTHORTY OF tHE COCA.COLA COMPANY aY

The Springfield Coca-Cola Bottling Co.

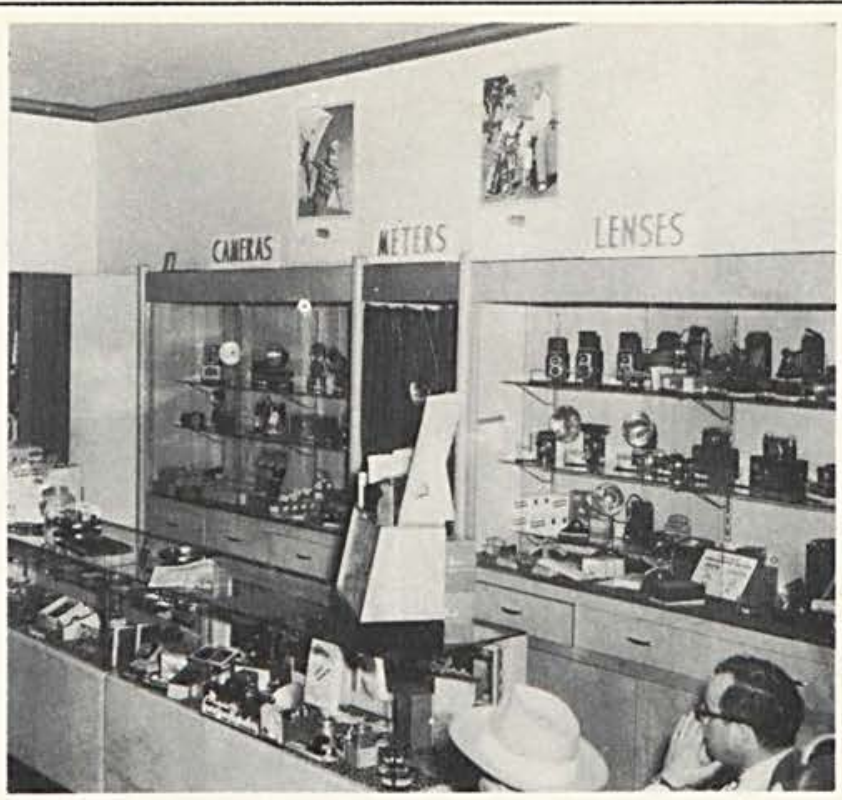

Choose

From

AMERICA'S

FINEST PHOTO

SUPPLIES

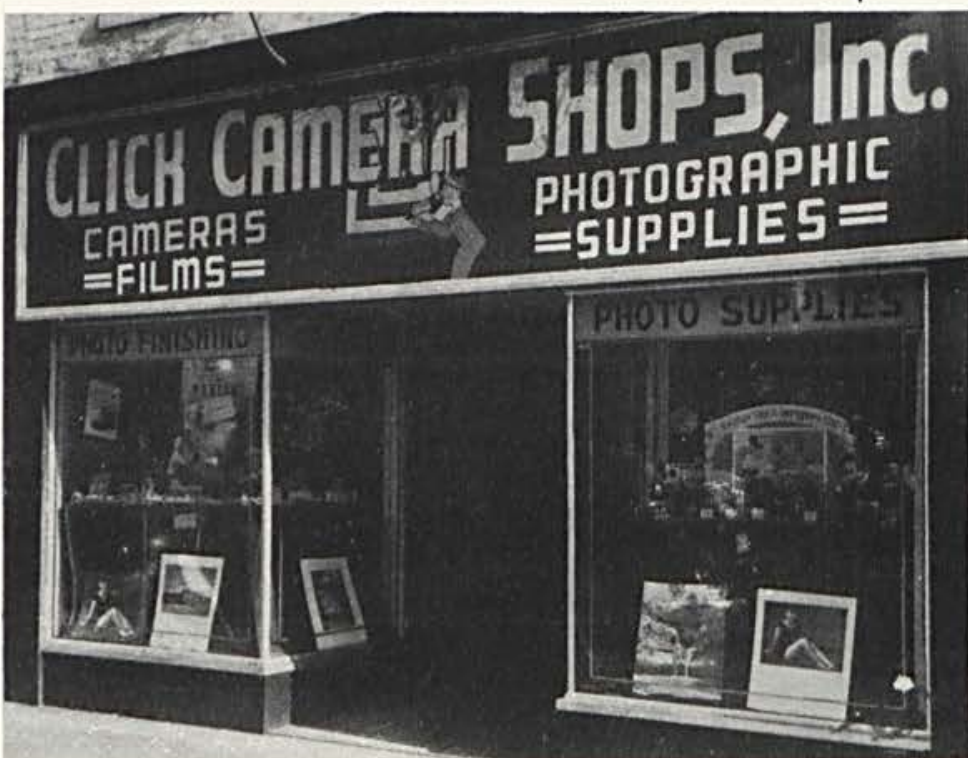




\section{XENIA ABATTOIR}

Wholesale Meats

Beef, Pork, Veal, Smoked Meats, Lard

Birch Road

R. R. \#2, Xenia, Ohio

Phone-339

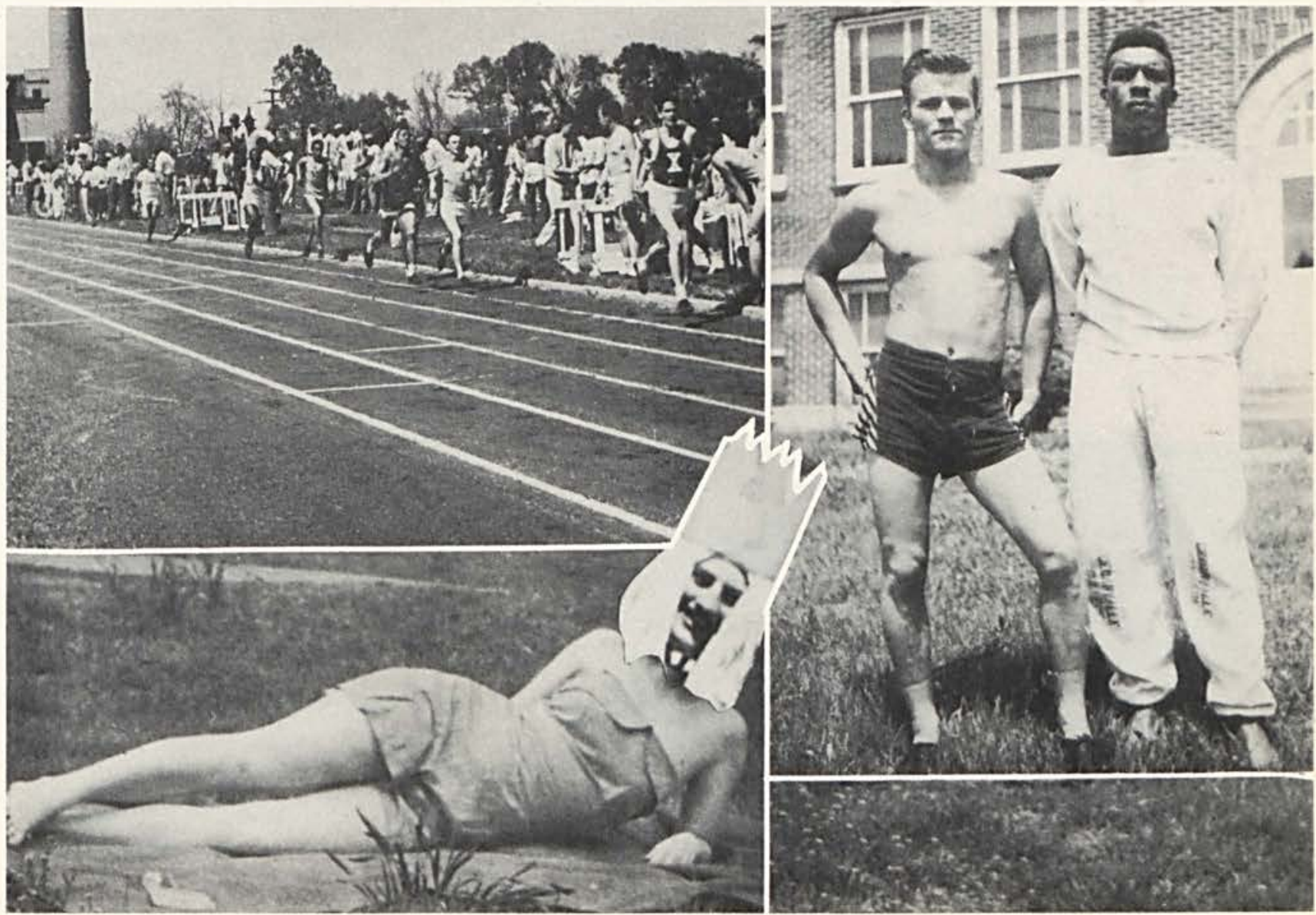




\section{CHETLOE'S}

DRY CLEANING

Post Office

Yellow Springs

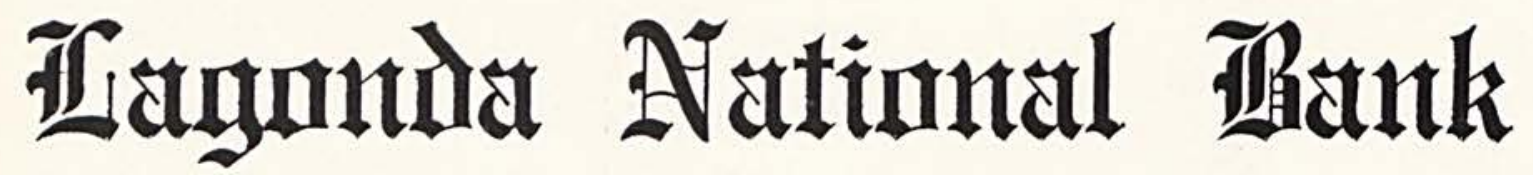

of Springfield, Ohio

\section{DOnnA's \\ BEAUTY SHOP}
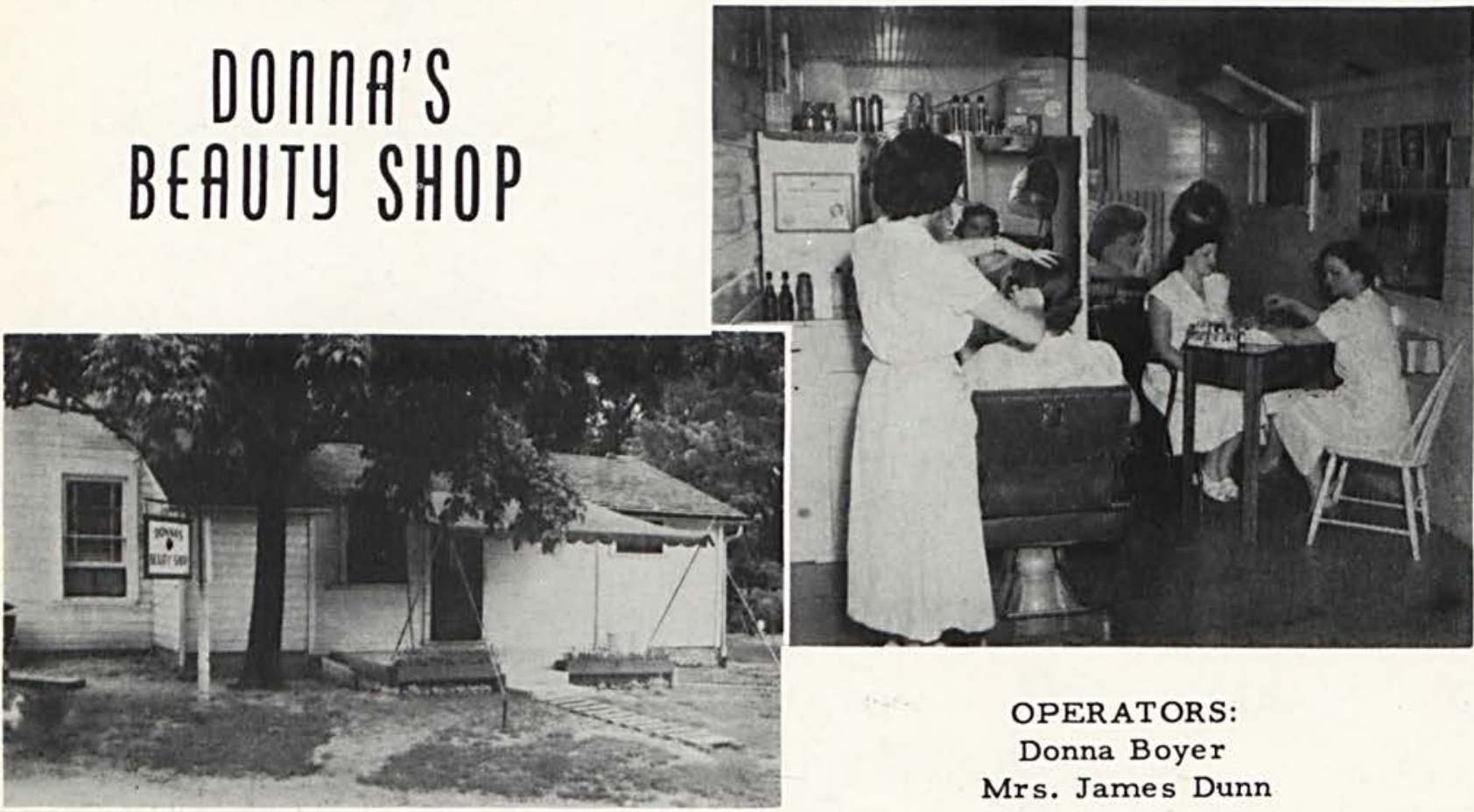

OPERATORS:

Donna Boyer

Mrs. James Dunn 


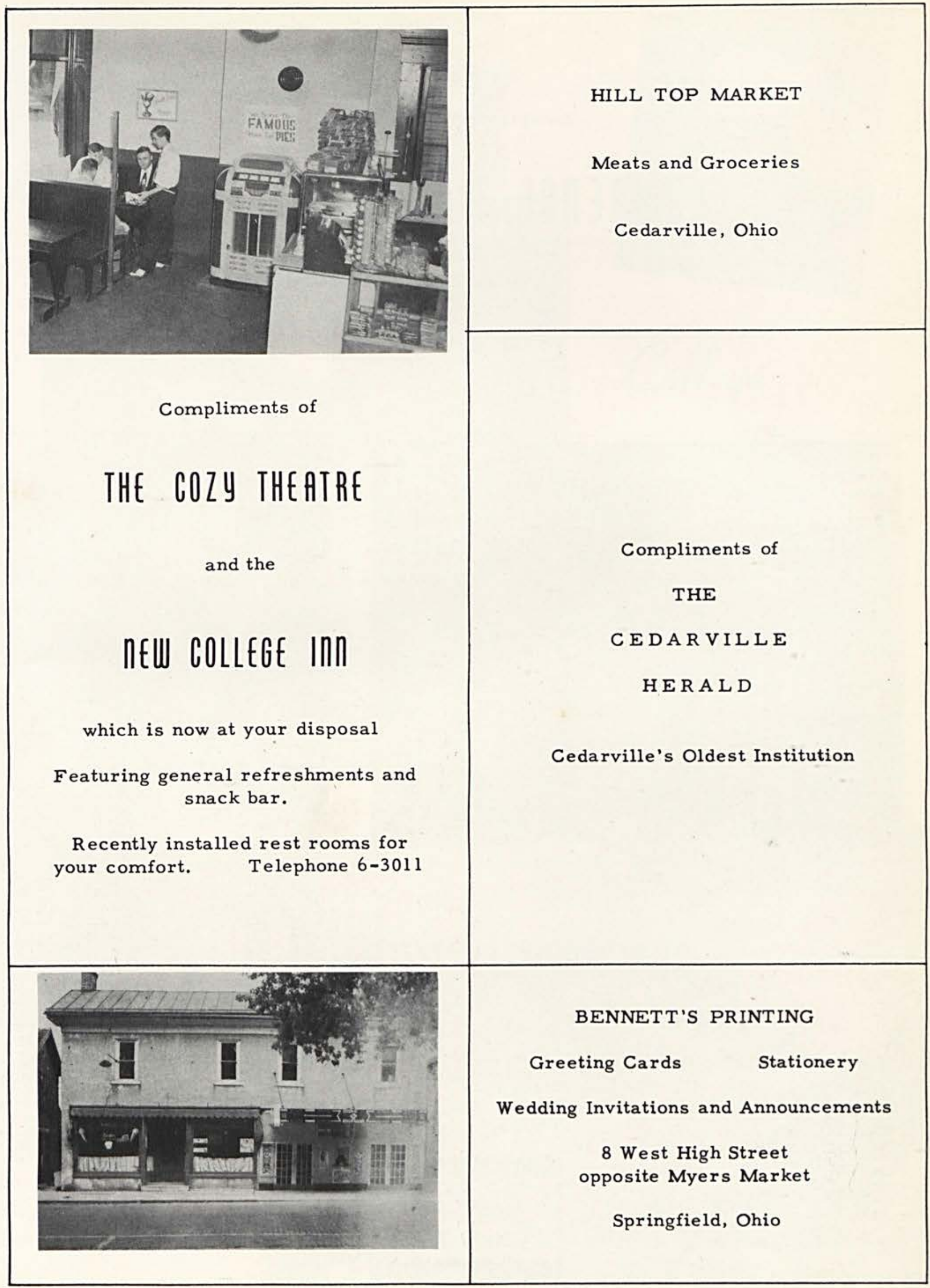


HUDSON

America's Safest Car

\section{LAWRERCE MOTORS, InC.}

123 N. Spring Street

Springfield, Ohio

Phone 5-1566
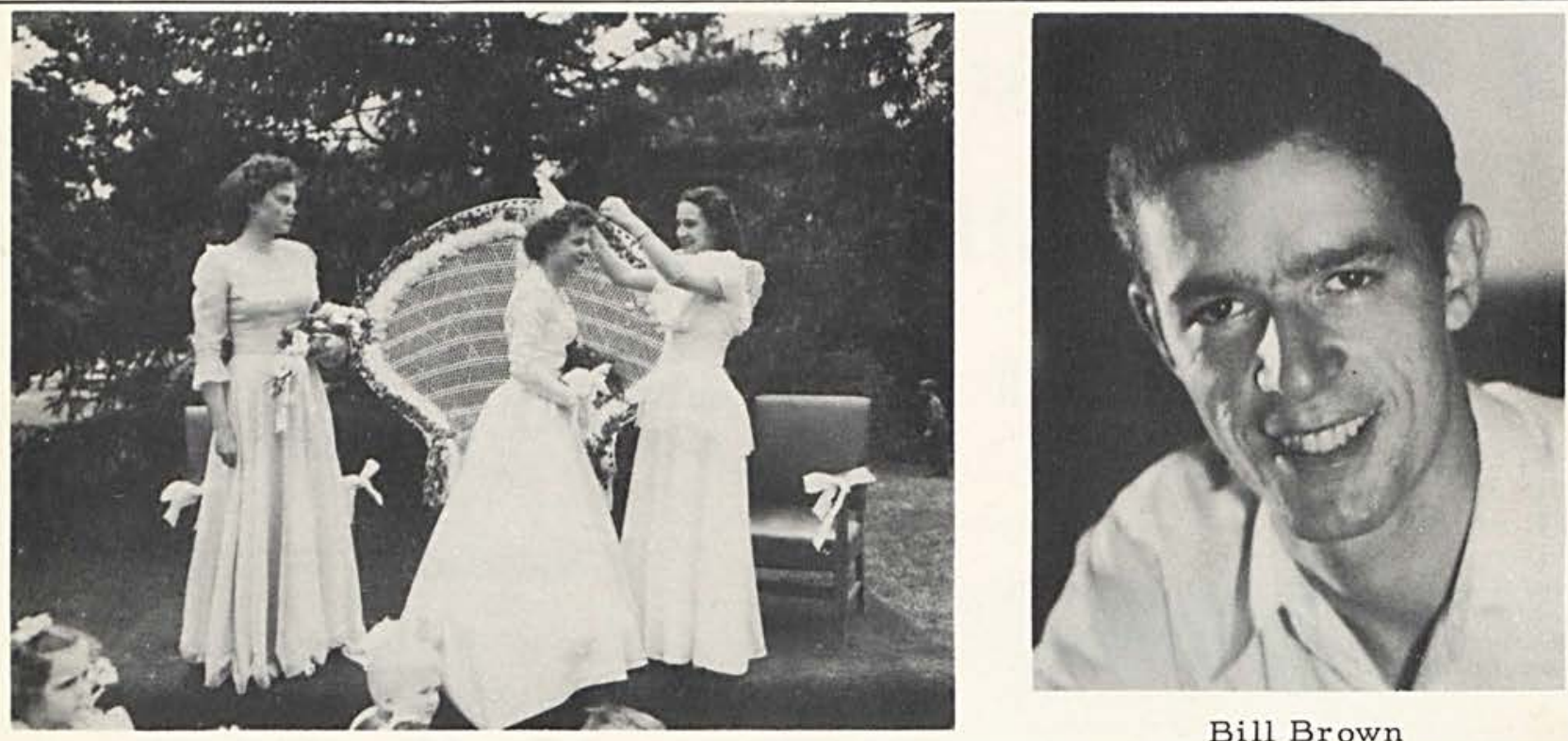

\section{Bill Brown}

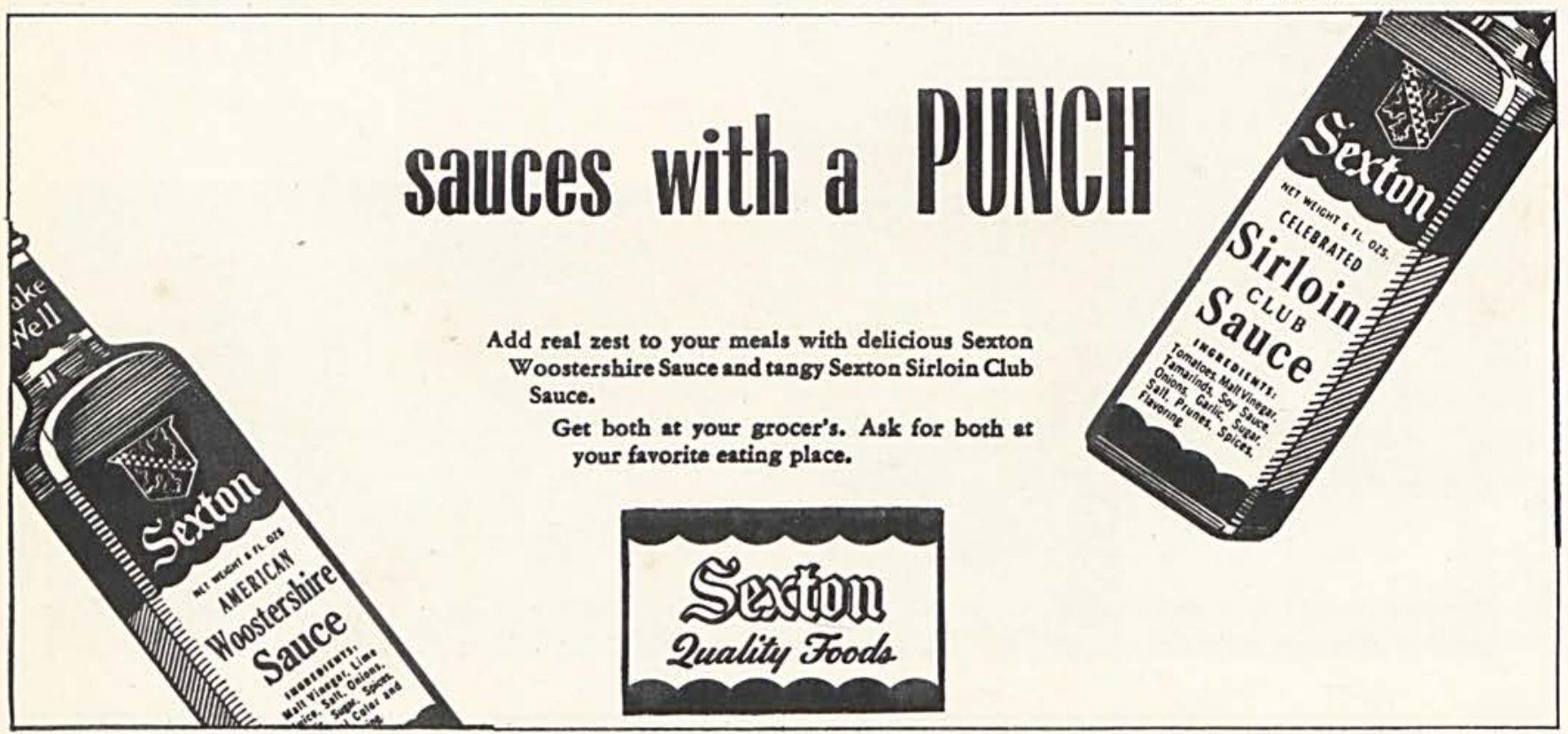




\section{PICKERING ELECTRIC}

Contractor and Dealer

Westinghouse Appliance,

Sunbeam Appliance

Easy Washers, Philco Television and Radio Hoover Cleaners Sales and Service

Cedarville, Ohio

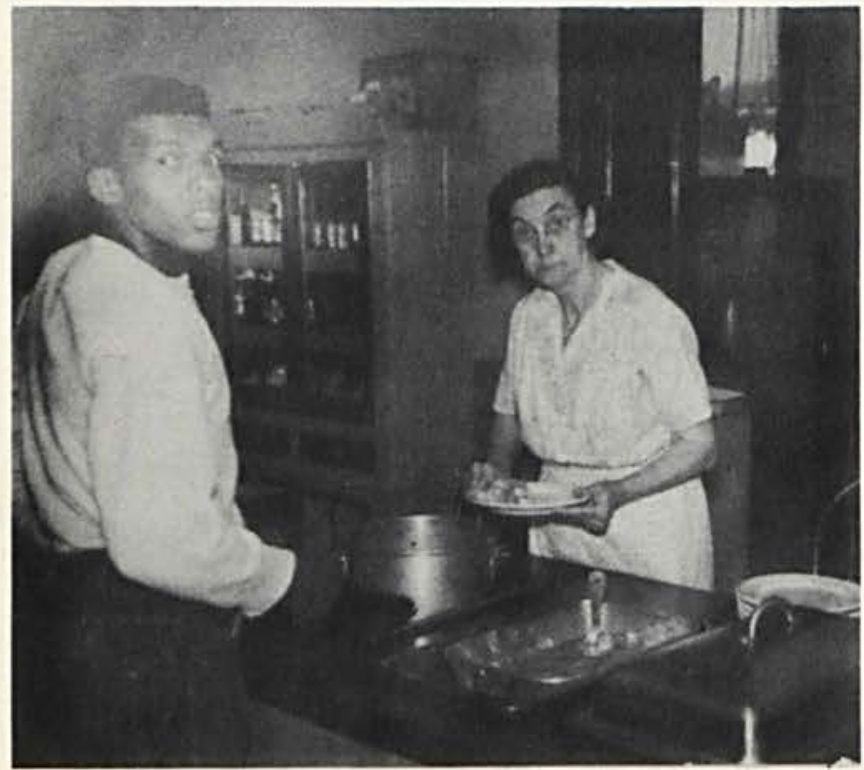

Compliments of

HILLTOP SERVICE STATION

Cedarville, Ohio

Sunoco Gas and Oils

\section{VOGUE}

SHOD

Springfield, Ohio

Specializing in

University-Styled Clothes for Men
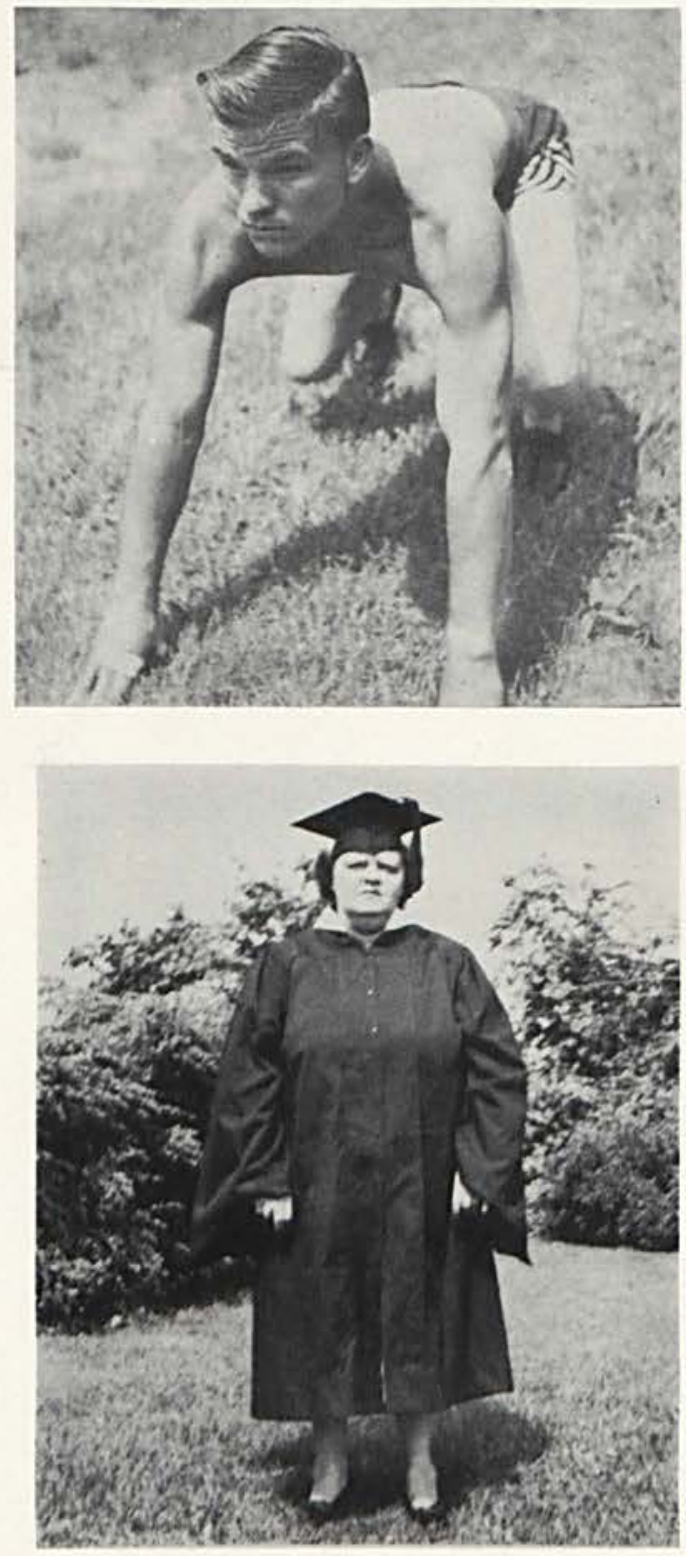


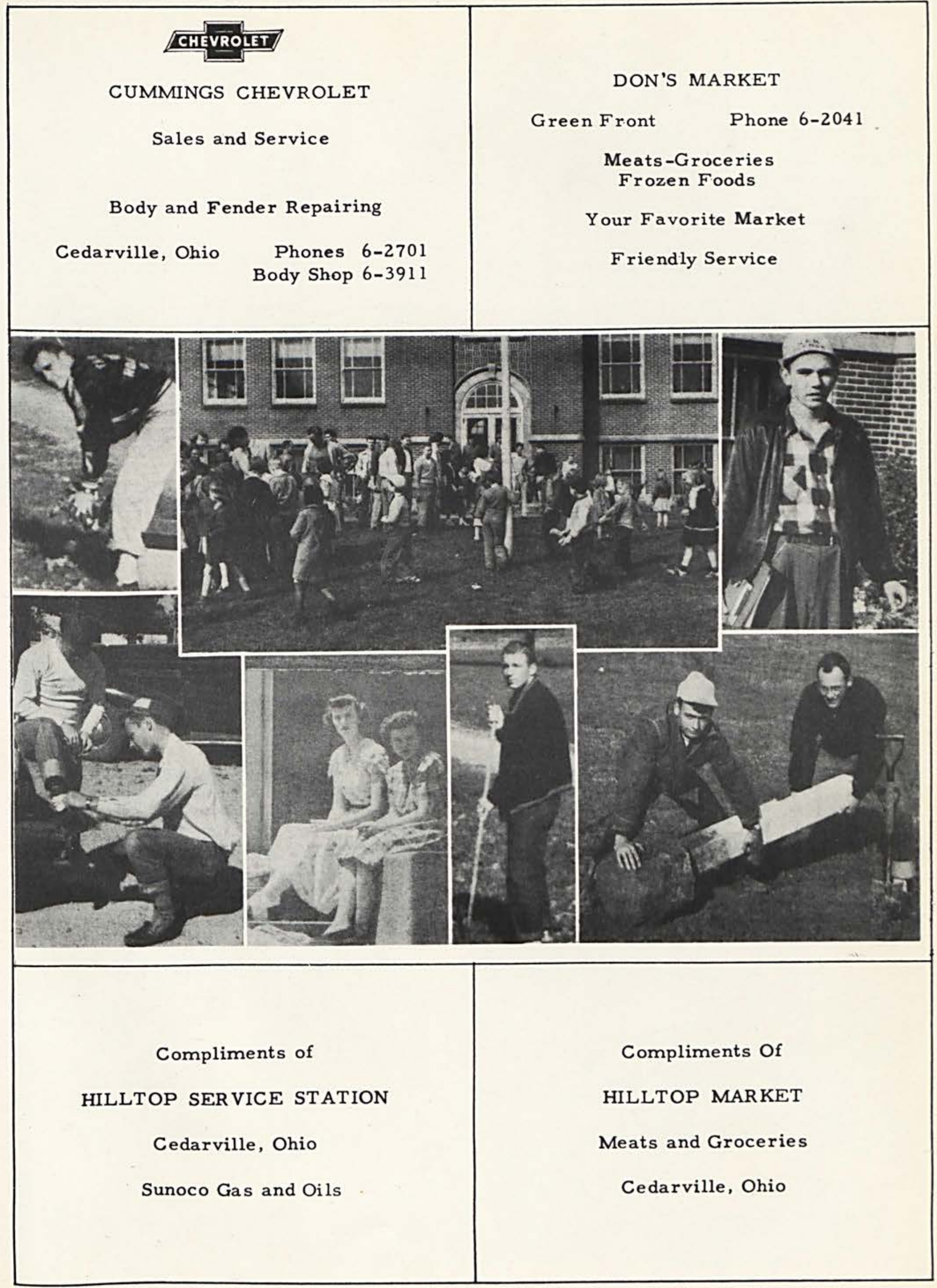




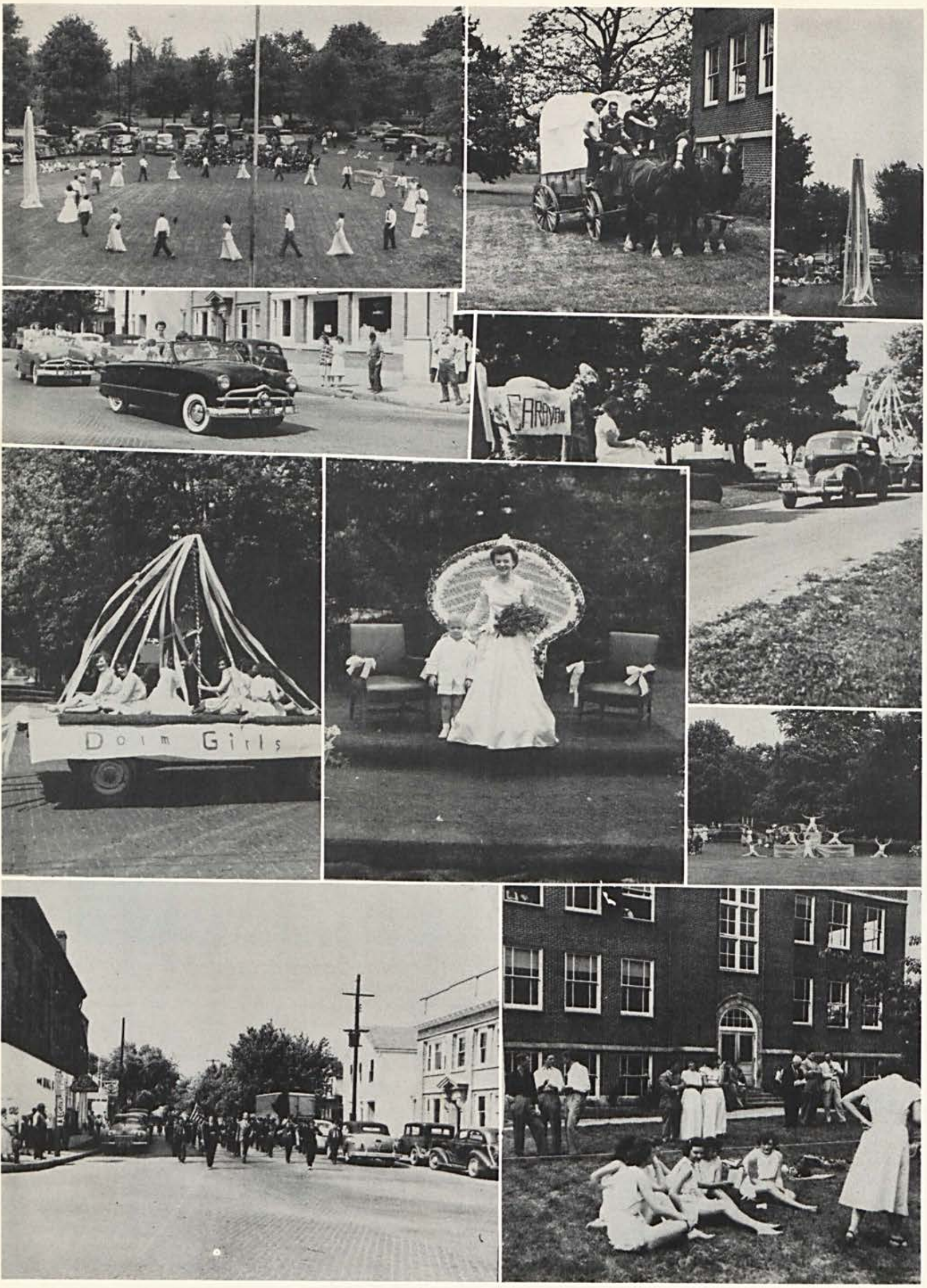




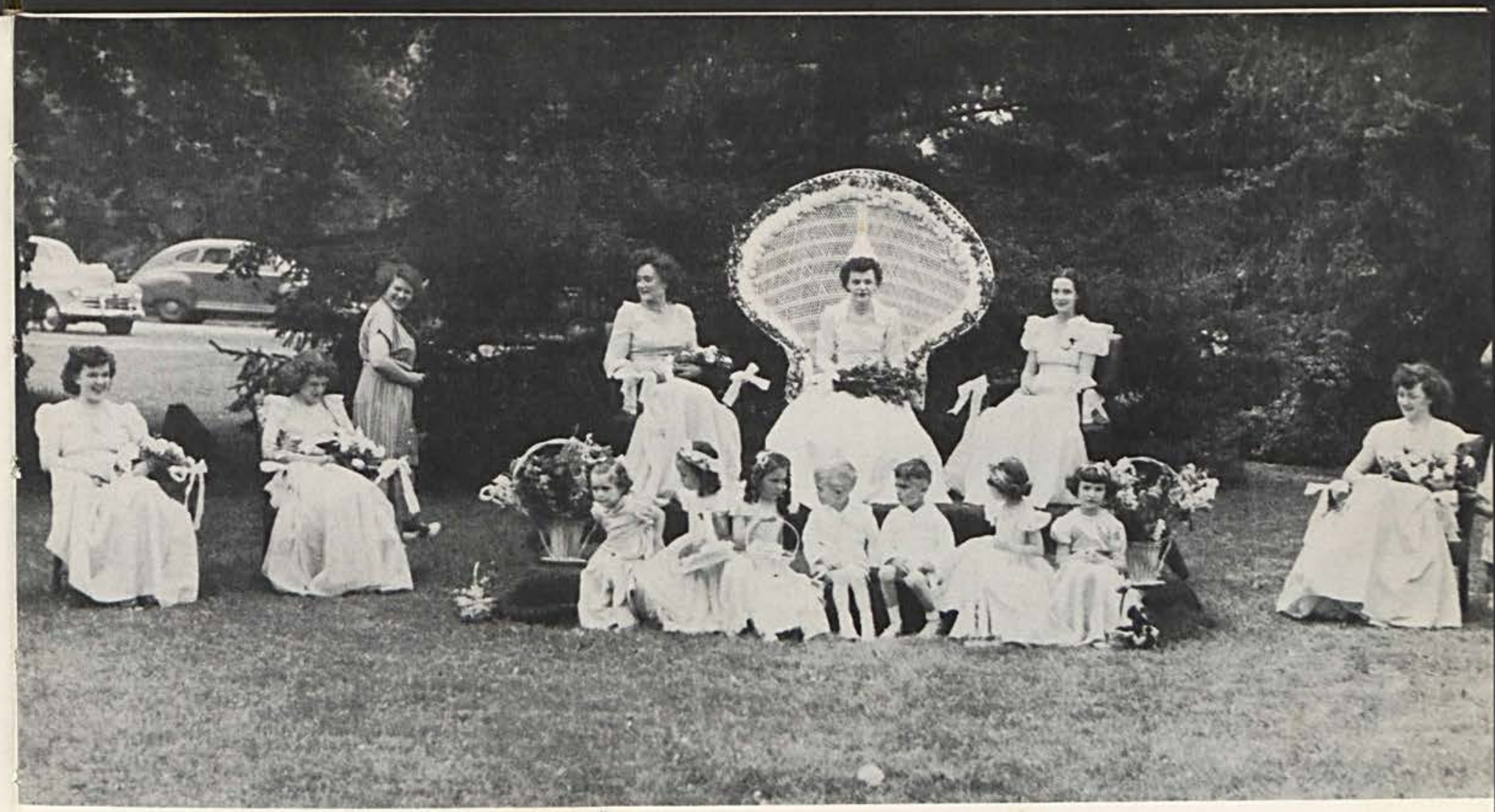

FIRST ROW: KatHLEen EVANS, Marie FISHER, CAROL LILLICK, JOANN CUMMINGS, SUe RIFE, BUTCH IRVINE, JOHN RIFE, MARY LEE CUMMINGS, SUE REYNOLDS, CHARLOTTE COLLINS, ERIC SMITH. SECOND ROW: ILA MCLAUghLin, NAOMI CONNER, BEA ALlen.

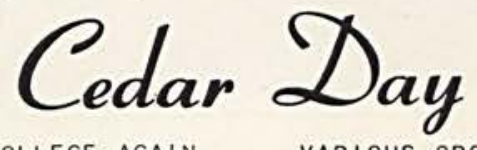

ON MAY 15, 1949, CEDARVILLE COLLEGE AGAIN OBSERVED CEDAR DAY FOR THE FIRST TIME IN SEVERAL YEARS. REIGNING OVER THE FESTIVITIES OF THE DAY WAS OUR QUEEN, MISS NAOMI CONNER, A NATIVE OF CEDARVILLE. THE QUEEN AND HER COURT WERE ELECTED BY THE VOTE OF THE ENTIRE STUDENT BODY.

THE FESTIVITIES BEGAN IN THE MORNING WITH A PARADE THROUGH TOWN LED BY THE SPRING VALLEY HIGH SCHOOL BAND FOLLOWED BY THE QUEEN AND HER COURT IN CONVERTIBLES AND FLOATS REPRESENTING THE
VARIOUS ORGANIZATIONS OF THE COLLEGE. ON THE BEAUTIFUL CAMPUS OF CEDARVILLE COLLEGE MIDST THE CEDAR TREES OUR GUEEN, NAOMI CONNER, WAS CROWNED BY THE LAST CEDAR DAY QUEEN, MRS. ROBERT ALLEN (BEA COLLIER).

A DANCE OF THE RAINBOW GIRLS, A WALTZ ROUTINE, THE MAY POLE DANCE, BALLET, AND MODERN DANCING PROVIDED THE ENTERTAINMENT FOR THE QUEEN AND HER COURT.

\section{CONFARR'S PANTRY}

Cedarville, Ohio

Phone 6-2773

Student Headquarters

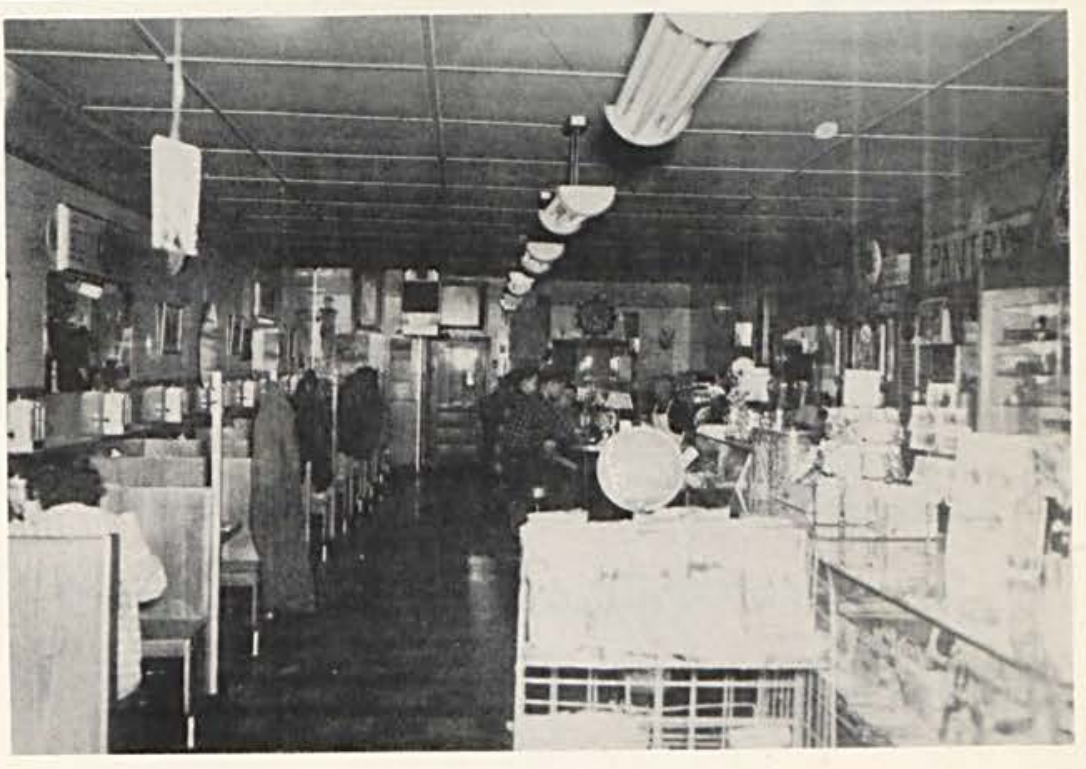




\section{The STOKES MOTOR Co.}

S. Main St.

Cedarville, Ohio
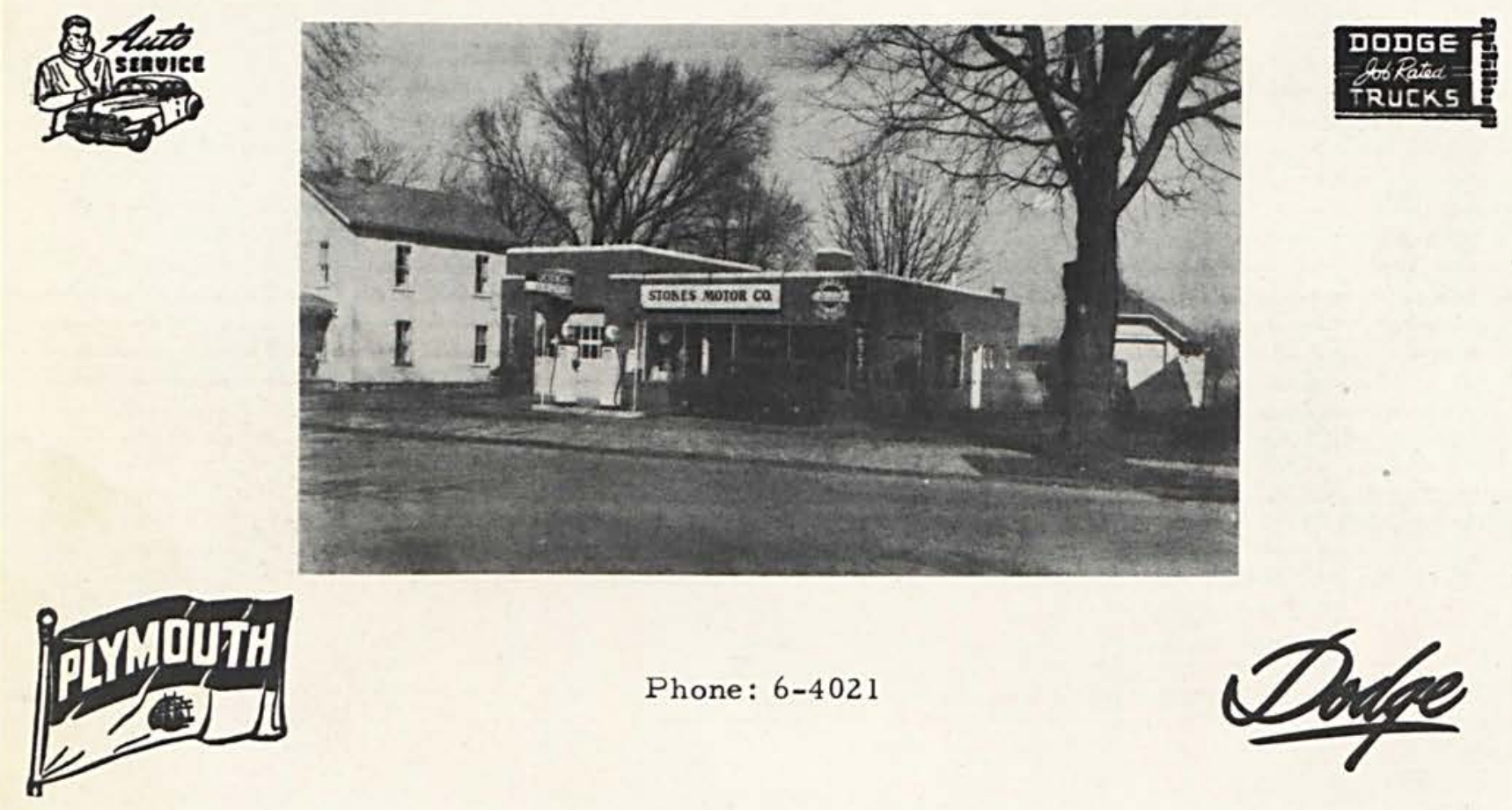

Phone: 6-4021
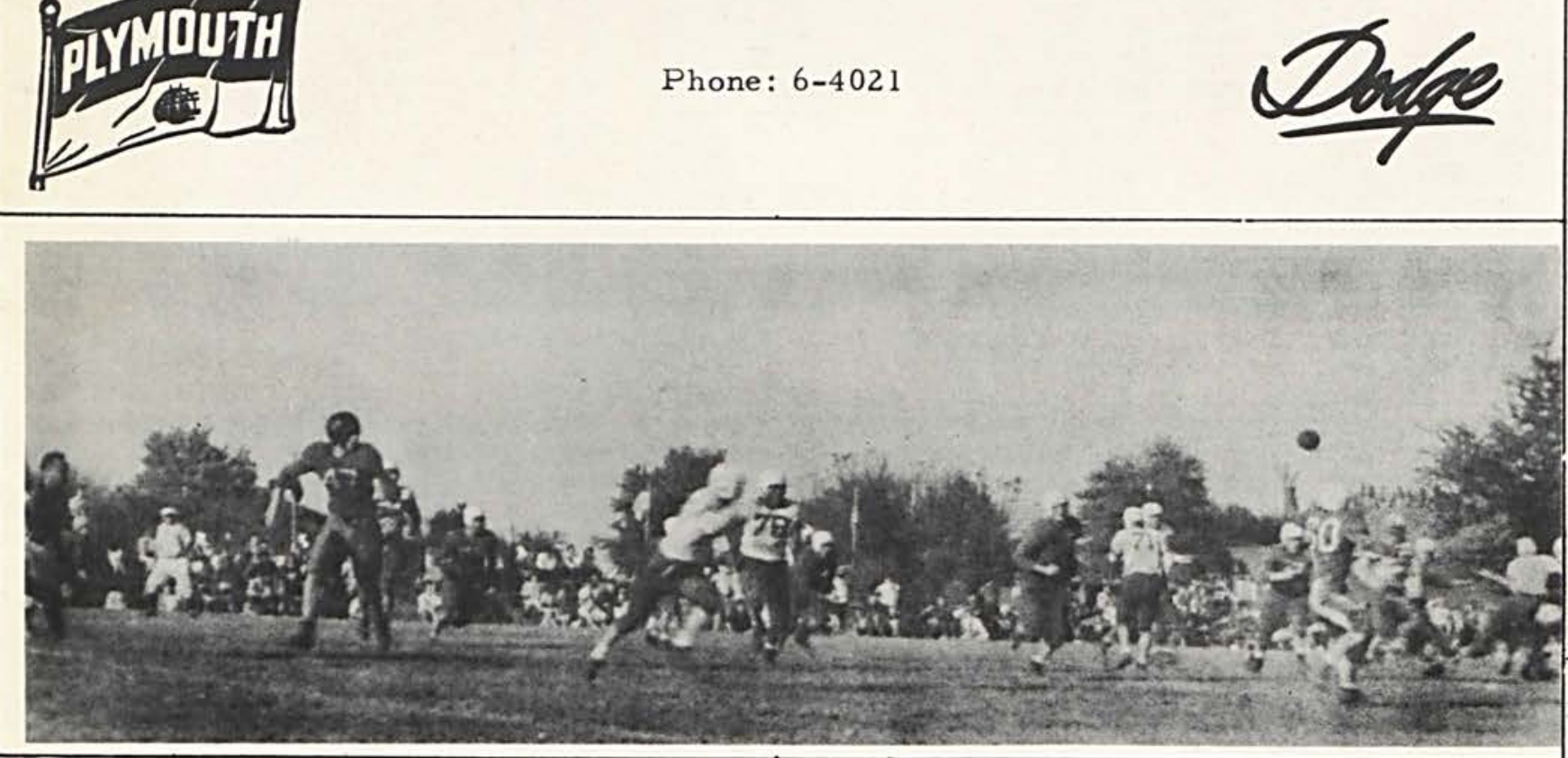

U can stretch ur \$ by buying ur dry goods, clothing, shoes and notions from us

Also the Best Auto Insurance and Cuickest Service in Greene County

HOME CLOTHING COMPANY

Cedarville, Ohio

G. H. Hartman, Prop.
Compliments of

THE NEW CEDARVILLE CLEANERS

Dry Cleaning \& Allied Service

Hours 9 to 6 P.M. Daily

Sat. 9 til 10 
Compliments of

$\begin{array}{ll}\text { HAMMAN'S } & \text { DAIRY } \\ \text { Milk } & \text { Cream }\end{array}$

All pasteurized dairy products

Phone 6-2941
Compliments of

DUVALL HARDWARE

Cedarville, Ohio

Phone: 6-1941

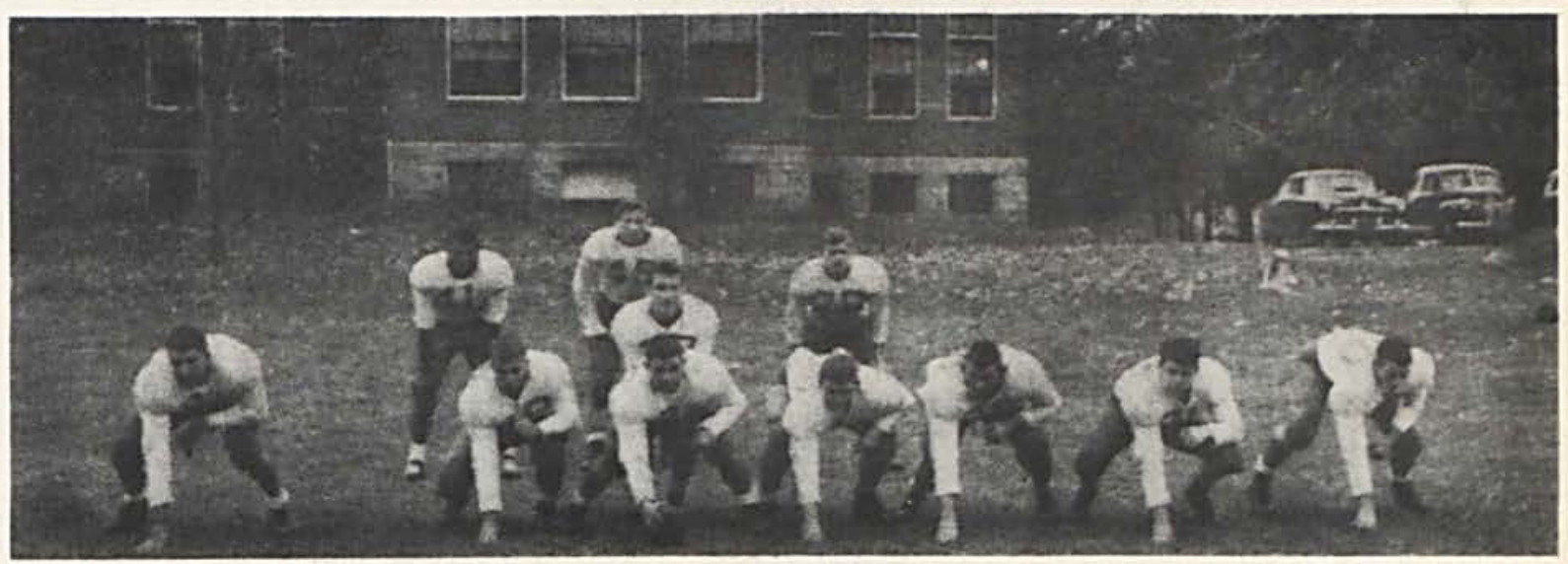

\section{XENIA NATIONAL BANK}

1835--Over a Century of Service--1950

Capital Funds, $\$ 620,000$
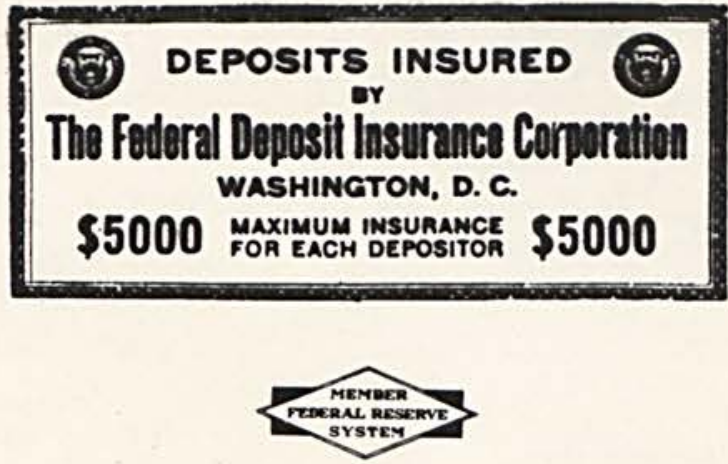

You are never a stranger after your first visit to our bank 


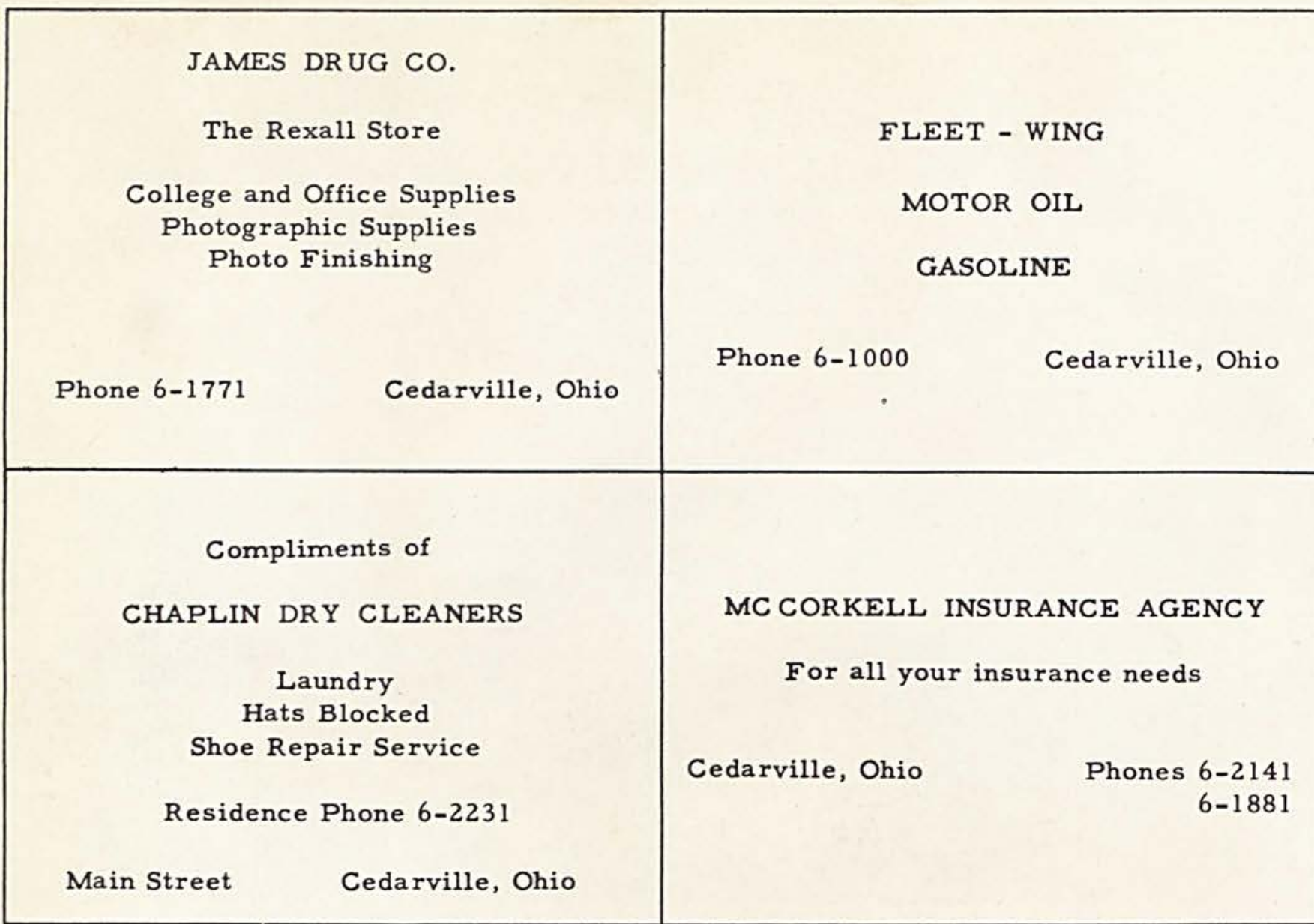

\section{HARIER \& HUSTON}

CEDAR VILLE MARKET

It Pleases Us To Please You

MEATS VEGETABLES GROCERIES 
H. E. ULLERY, Prop.

Compliments of

\section{ULLERY'S ELEVATOR CEDARVIHLE, OHIO \\ Phone 6-2021}

\section{Compliments of}

PRICE VAULT CO.

Marysville, Ohio

Phone -8986

CEDARVILLE FEDERAL SAVINGS

AND LOAN ASSOCIATION

Savings Accounts

Loans on Real Estate
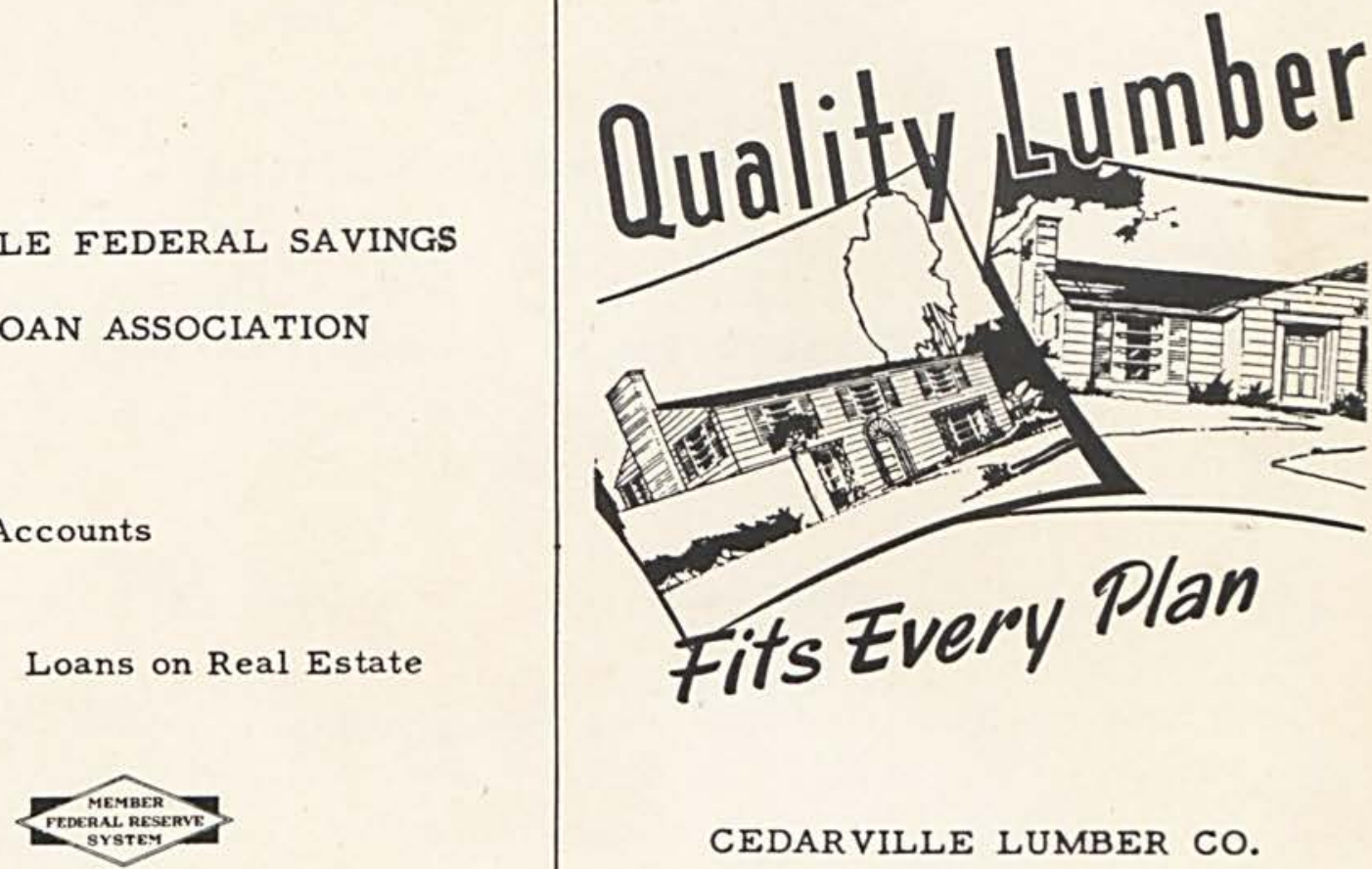

Cedarville, Ohio

CEDARVILLE LUMBER CO.

"Dedicated to Serve"

6-1331 Cedarville, Ohio 


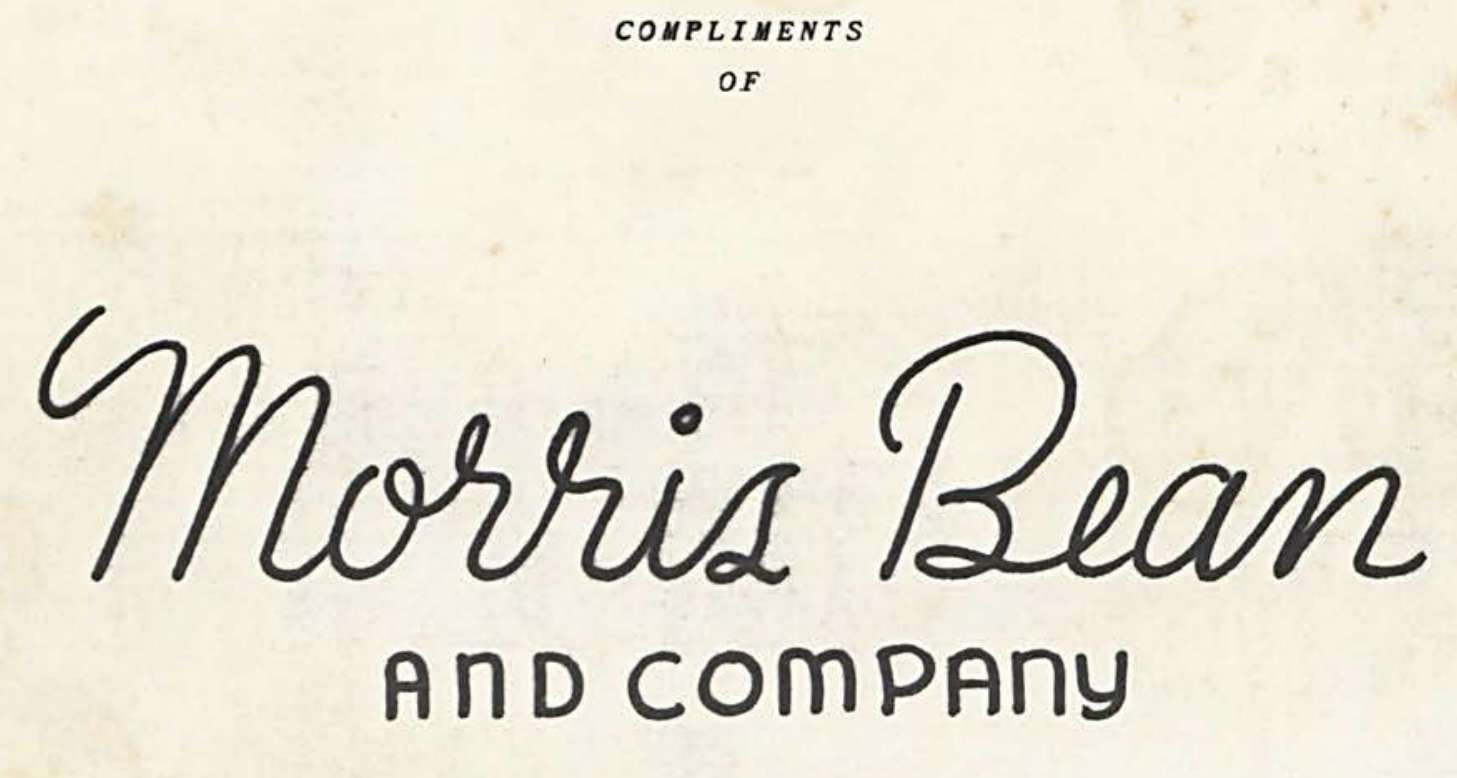

PLANTS

at

YELLOW SPRINGS AND CEDARVILLE

MANUFACTURERS OF ALUMINUM CASTINGS

for

TIREMOLDS,

AIRCRAFT,

and many other purposes. 


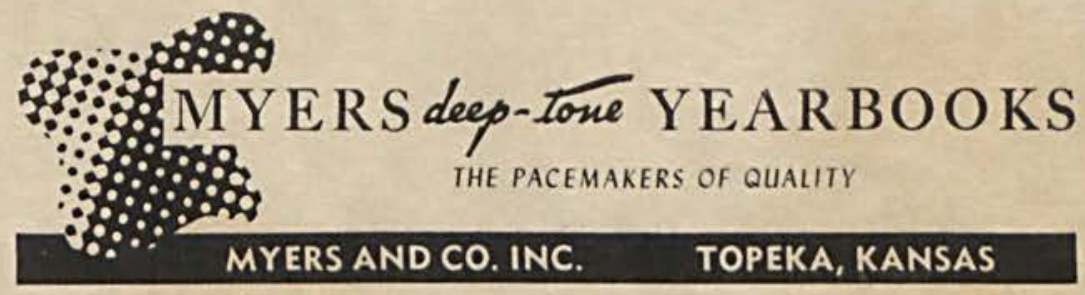


$R=$

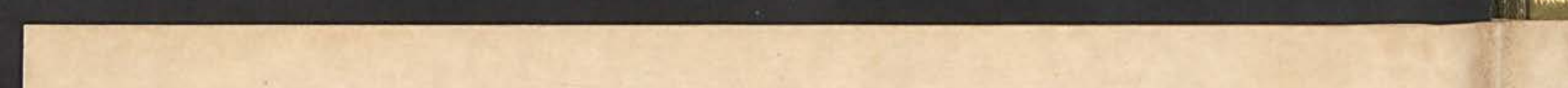


